\title{
Behavior of Spent Nuclear Fuel and Storage System Components in Dry Interim Storage.
}

August 1982

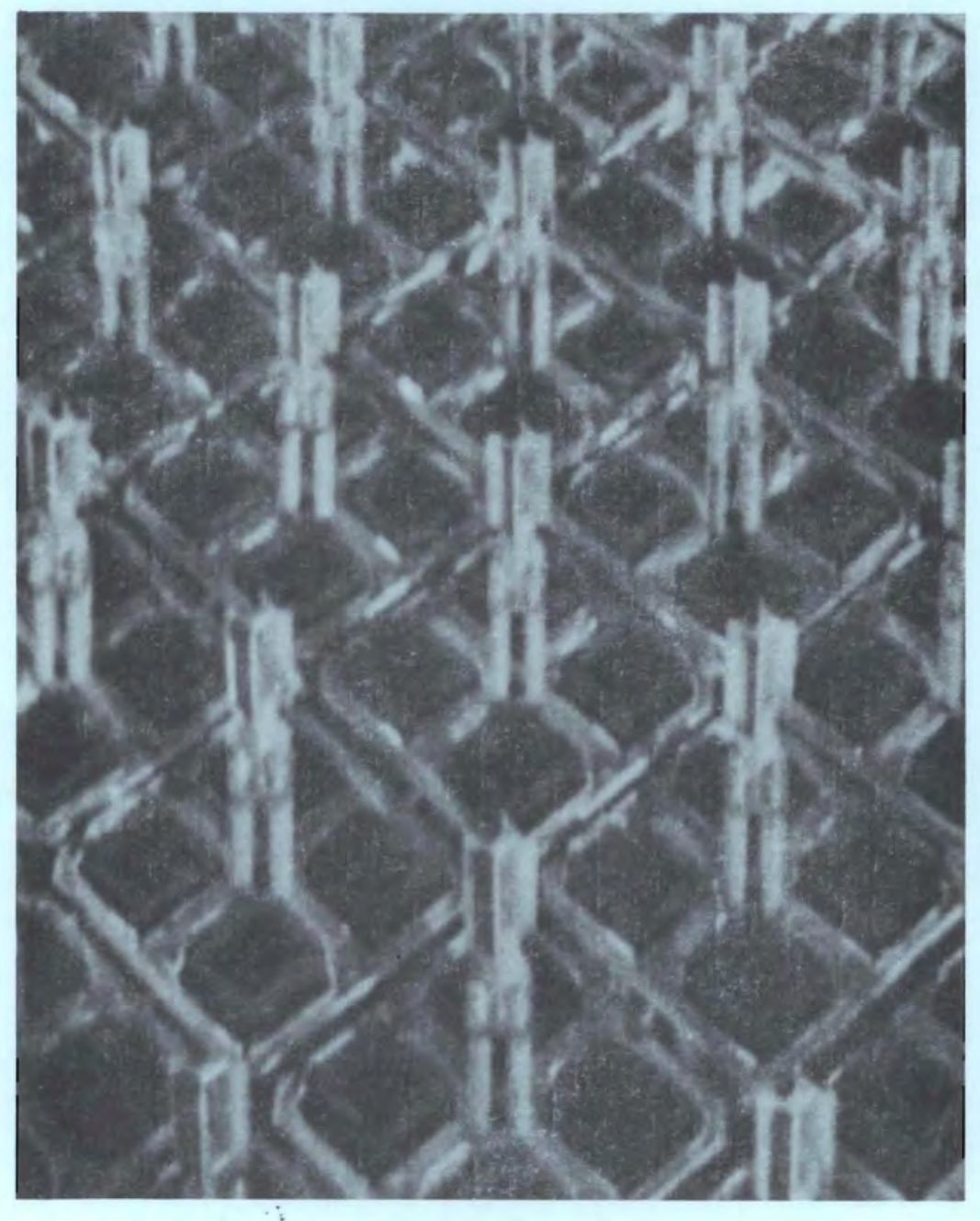

Prepared for the U.S. Department of Energy under Contract DE-AC06-76RLO 1830

Pacific Northwest Laboratory Operated for the U.S. Department of Energy by Battelle Memorial Institute 


\title{
DISCLAIMER
}

This report was prepared as an account of work sponsored by an agency of the United States Government. Neither the United States Government nor any agency thereof, nor any of their employees, makes any warranty, express or implied, or assumes any legal liability or responsibility for the accuracy, completeness, or usefulness of any information, apparatus, product, or process disclosed, or represents that its use would not infringe privately owned rights. Reference herein to any specific commercial product, process, or service by trade name, trademark, manufacturer, or otherwise, does not necessarily constitute or imply its endorsement, recommendation, or favoring by the United States Government or any agency thereof. The views and opinions of authors expressed herein do not necessarily state or reflect those of the United States Government or any agency thereof.

\author{
PACIFIC NORTHWEST LABORATORY \\ operated by \\ BATTELLE \\ for the \\ UNITED STATES DEPARTMENT OF ENERGY \\ under Contract DE-AC06-76RLO 1830
}

\begin{tabular}{|c|c|}
\hline \multicolumn{2}{|c|}{$\begin{array}{c}\text { Printed in the United States of America } \\
\text { Available from } \\
\text { National Technical Information Service } \\
\text { United States Department of Commerce } \\
5285 \text { Port Royal Road } \\
\text { Springfield, Virginia } 22151\end{array}$} \\
\hline \multicolumn{2}{|c|}{$\begin{array}{l}\text { NTIS Price Codes } \\
\text { Microfiche A01 }\end{array}$} \\
\hline \multicolumn{2}{|c|}{ Printed Copy } \\
\hline Pages & $\begin{array}{l}\text { Price } \\
\text { Codes }\end{array}$ \\
\hline $001-025$ & $\mathrm{~A} 02$ \\
\hline 026-050 & $\mathrm{A} 03$ \\
\hline 051-075 & $\mathrm{A} 04$ \\
\hline $076-100$ & A05 \\
\hline $101-125$ & A06 \\
\hline $126-150$ & A07 \\
\hline $151-175$ & $\mathrm{~A} 08$ \\
\hline $176-200$ & A09 \\
\hline $201-225$ & A010 \\
\hline $226-250$ & A011 \\
\hline $251-275$ & A012 \\
\hline $276-300$ & A013 \\
\hline
\end{tabular}


PNL-4189

UC-85

BEHAVIOR OF SPENT NUCLEAR FUEL

AND STORAGE SYSTEM COMPONENTS

IN DRY INTER IM STORAGE

A. B. Johnson, Jr.

E. R. Gilbert

R. J. Guenther

August 1982

Prepared for

the U.S. Department of Energy

Under Contract DE-AC06-76RLO 1830

Pacific Northwest Laboratory

Richland, WA 99352

DOE-Richland, WA 

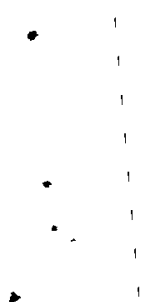

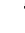

-

, 


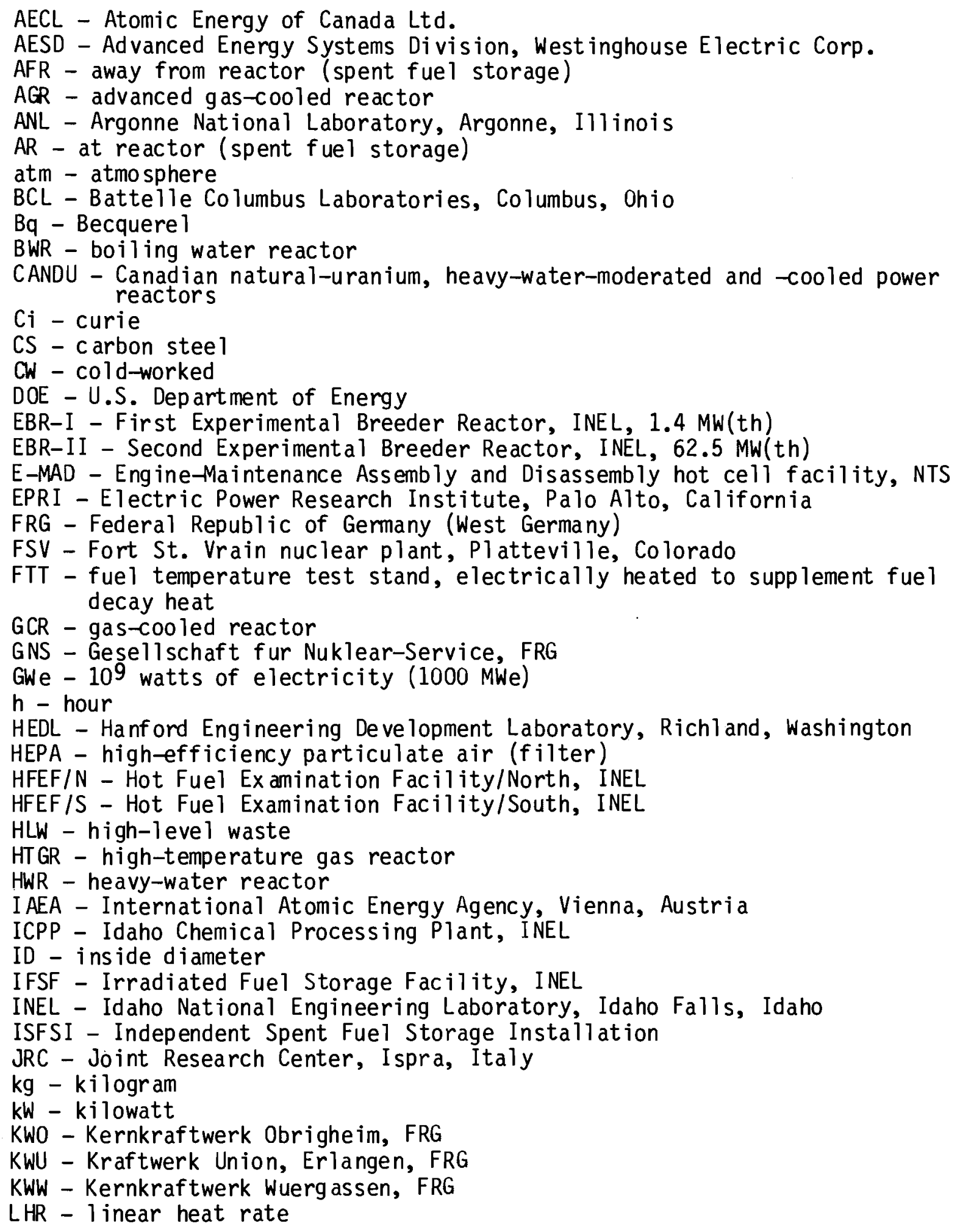




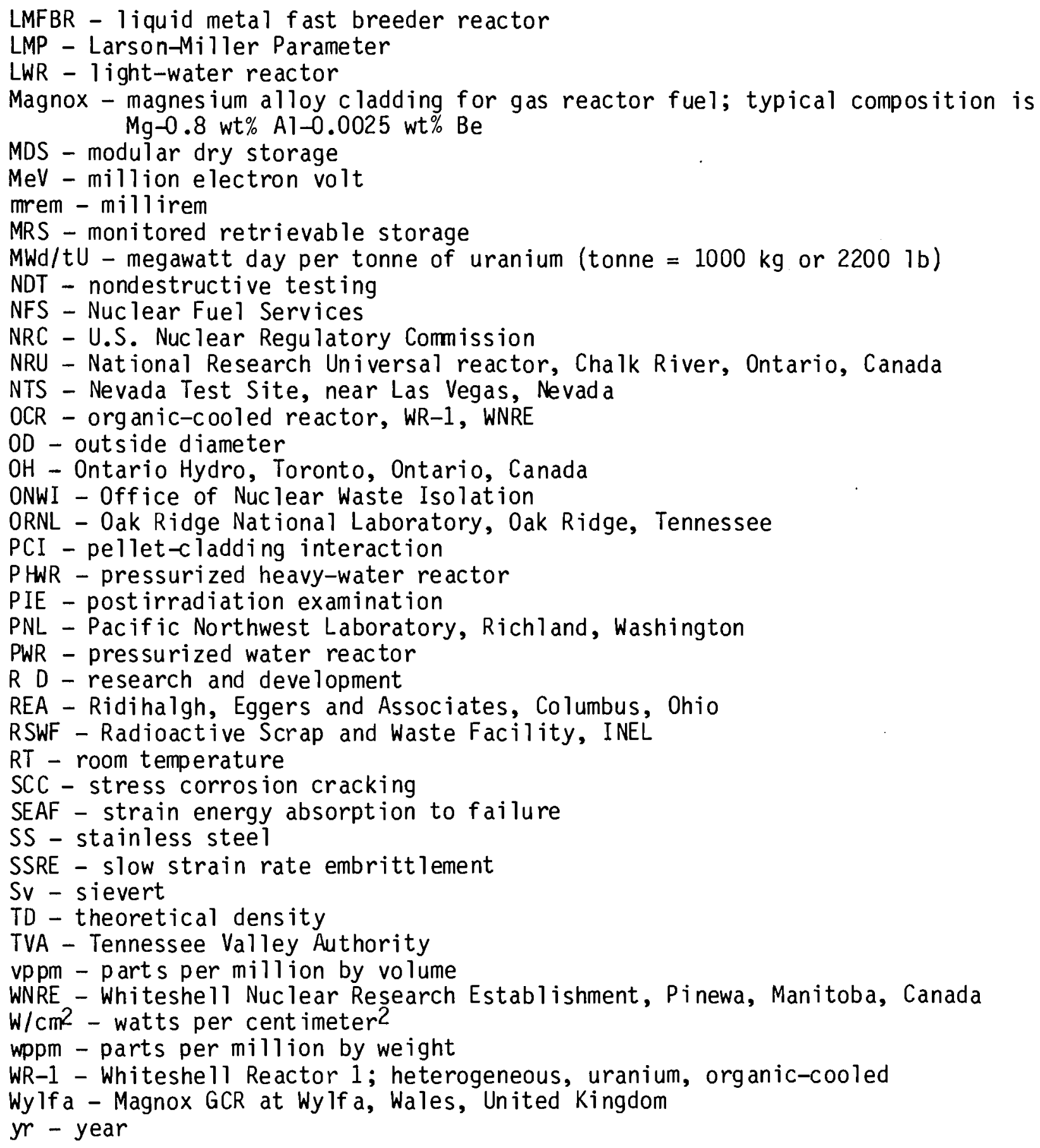


ACKNOWLEDGMENTS

The authors are grateful to A. R. Hakl of Westinghouse-Nevada for discussions of work at the Nevada Test Site (NTS) dry storage facilities; to R. J. Bahorich and R. Unterzuber of Westinghouse-AESD and L. B. Ballou of Lawrence Livermore National Laboratory for discussions regarding NTS fuel temperature histories; and to M. Peehs of Kraftwerk Union, B. Teer of Transnuclear, J. D. Rollins of GNS, and C. J. Ealing of GEC Energy Systems for pertinent discussions. The authors also acknowledge the following PNL personnel: B. M. Cole for providing fuel inventory assessments; R. A. McCann for assessing fuel temperature behavior in dry storage; R. L. Clark for calculation assistance; R. D. Nelson for comments on the draft; and S. K. Edler for editing and publication assistance.

The following organizations provided comprehensive reviews of the report: Boeing Company

Electric Power Research Institute

E. R. Johnson Associates, Inc. Northeast Utilities Service Co.

The Tennessee Valley Authority

U.S. Nuclear Regulatory Commission

Westinghouse Electric Corporation

and the following organizations reviewed sections of the report:

Argonne National Laboratory (Argonne West)

Auburn University

Exxon Nuclear-Idaho

Sandia National Laboratory.

This work was sponsored by the U.S. Department of Energy (DOE) under the Commercial Spent Fuel Management Program. 


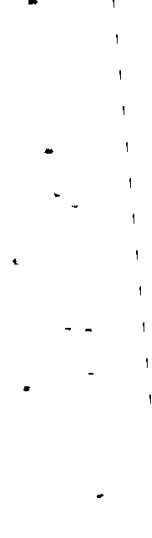




\section{ABSTRACT}

Irradiated nuclear fuel has been handled under dry conditions since the early days of nuclear reactor operation, and use of dry storage facilities for extended management of irradiated fuel began in 1964. Irradiated fuel is currently being stored dry in four types of facilities: dry wells, vaults, silos, and metal casks. Essentially all types of irradiated nuclear fuel are currently stored under dry conditions. Gas-cooled reactor (GCR) and liquid metal fast breeder reactor (LMFBR) fuels are stored in vaults and dry wells. Certain types of fuel are being stored in licensed dry storage facilities: Magnox fuel in vaults in the United Kingdom and organic-cooled reactor (OCR) fuel in silos in Canada. Dry storage demonstrations are under way for Zircaloy-clad fuel from boiling water reactors (BWRs), pressurized heavy-water reactors (PHWRs), and pressurized water reactors (PWRs) in all four types of dry storage facilities. The demonstrations and related hot cell and laboratory tests are directed toward expanding the data base and establishing a licensing basis for dry storage of water reactor fuel.

This report reviews the scope of dry interim storage technology, the performance of fuel and facility materials, the status of programs in several countries to license dry storage of water reactor fuel, and the characteristics of water reactor fuel that relate to dry storage conditions. 


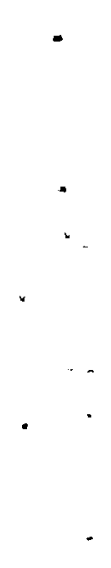




\section{SUMMARY AND CONCLUSIONS}

The principal purpose of this report is to assess the characteristics and behavior of 1 ight-water reactor $(L W R)^{(a)}$ fuel in dry interim storage. However, much dry storage experience involving other fuel types is relevant to LWR fuel storage; therefore, that technology is also assessed in this report. The experience has included safety analyses, fuel emplacement and retrieval, cover gas technology, and facility design and operation.

STATUS OF SPENT FUEL MANAGEMENT FOR WATER REACTOR FUEL

Reprocessing of water reactor fuel developed slowly, and it is unlikely that reprocessing will have a major impact on the U.S. inventory of spent fue 1 stored in water reactor basins before the end of the century. Disposal technology for unreprocessed fuel is being evaluated; however, even if a decision is reached to dispose of part or all of the LWR inventory, licensed repositories are not expected until near the end of the century. Therefor?, interim storage will continue to fill a major role in spent fuel management for at least the next two decades.

Wet storage is currently the major interim storage option in the United States, and it will be essential as long as water reactors operate. Approximately 18,000 boiling water reactor (BWR) spent fuel assemblies and $\sim 11,000$ pressurized water reactor (PWR) spent fuel assemblies were in wet storage in the United States at the end of 1981. By 1986, it is estimated that the inventory will increase to $\sim 38,000$ BWR assemblies and $\sim 25,000$ PWR assemblies. Although it is likely that wet storage will remain the major option for interim storage of U.S. water reactor fuel, dry storage is an attractive alternative that is being evaluated in several countries.

INCENTIVES TO DEVELOP DRY INTER IM STORAGE FOR WATER REACTOR FUEL

Wet storage of spent fuel has a long-standing history of satisfactory performance that dates back to 1943. However, there are several incentives to develop dry interim storage:

(a) The glossary ( $p$. iii) defines abbreviations, acronyms, and terms used in this report. 
- Flexibility is provided to meet a range of utility needs.

- Cooling can be completely passive, which precludes concerns regarding interruption of coolant flow.

- Cover gas control and monitoring requirements are less extensive for most dry storage concepts than for wet storage.

- Some dry storage concepts can be added in modules, precluding large front-end capital costs.

- It is feasible that less secondary radioactive wastes could be generated as compared with wet storage facilities.

The time required to bring a storage option on-line is another consideration. In the United States, some reactors will need to add storage capacity as early as 1984-1986. If licensing develops on a timely basis, a dry storage option could be provided in that time period, particularly if the concept is modular.

DRY STORAGE CONCEPTS

Various terms have developed for dry storage concepts. (a) In this report we will ident ify four concepts:

- dry wells

- vaults

- silos

- metal storage casks.

Dry wells, silos, and casks are modular; vaults may or may not be modular depending on the design. In this report the term canister will refer to metal containers that encase fuel assemblies before they are placed in storage. The term rod consolidation refers to the process of removing fuel rods from the assembly hardware and placing them in a canister in close-packed arrays to increase storage density. Criticality considerations must be factored into assessments of various storage modes; however, the subject of criticality is beyond the scope of this report.

(a) See Appendix A for a discussion of dry storage concept terminologies. 
The data base for dry storage of irradiated fuel is derived from:

- experience with handling and shipping of all types of irradiated fuel under dry conditions that extends back to the early days of nuclear reactor operation

- extended dry storage of gas-cooled reactor (GCR) and liquid metal fast breeder reactor (LMFBR) fuels in vaults and dry wells that has involved Magnox, graphite, and stainless steel (SS) cladding

- dry storage demonstrations involving Zircaloy-clad fuel

- laboratory and hot cell studies of Zircaloy-clad fuel directed to specific dry storage-related phenomena

- literature relevant to definition of water reactor fuel behavior under dry storage conditions.

DRY STORAGE EXPERIENCE

Dry interim storage is a licensed technology for certain types of fuel: Magnox fuel in the United Kingdom; WR-1 fuel in Canada; and a BWR fuel demonstration in the Federal Republic of Germany. Dry storage is also emerging as a potentially important alternative to wet storage for water reactor fuel.

Fuel Handling Under Dry Conditions

Irradiated fuel has been handled dry almost from the beginning of nuclear reactor operation. Fuel has been inspected and stored dry at hot cells, and it has been shipped dry in casks. Some Zircaloy-clad fuel rods have been stored dry for up to a decade at hot cells, although at relatively low temperatures $\left(<100^{\circ} \mathrm{C}\right)$. Hundreds of Zircaloy-c lad assemblies have been shipped dry in single-assembly and multiassembly casks. Assemblies ordinarily remain in truck casks from a few days up to two weeks. Fuel shipped by sea from Jap an to Europe resides in dry casks for 2 to 3 months. 
There is a large bank of successful experience with dry handling of essentially every type of irradiated fuel. This experience supplements the direct experience with dry storage of GCR and LMFBR fuel and the several dry storage demonstrations with Zircaloy-clad fuel.

Dry Storage Experience with GCR and LMFBR Fuel

The earliest extended dry storage experience involves LMFBR fuel stored in vaults and dry wells at the Idaho National Engineering Laboratory (INEL), Idaho Falls, Idaho, beginning in 1964. Additional dry storage facilities began operation at INEL in 1971 (dry wells for GCR fuel), 1974 (dry wells for LMFBR fuel), and 1975 (vaults for GCR and LMFBR fuels). The first dry storage vault (cells 1-3) for Magnox (GCR) fuel began operation at Wylfa, Wales in 1971; and a second vault (cells 4 and 5) began operating at Wylfa in 1979.

A dry interim storage vault for high-temperature reactor fuel has been constructed at the Julich Experimental Power Plant (FRG), and a storage vault for JRR-3 test reactor fuel was completed in Japan in 1982. A dry storage facility (TOR) for Phenix (LMFBR) fuel is expected to begin operatioil in France in 1983.

The substantial experience represented by the facilities ident ified above includes:

- safe emplacement, storage, and retrieval of irradiated fuel in dry wells and vaults

- use of air, argon, carbon dioxide, and helium cover gases

- methods to monitor and maintain inert cover gas purity

- development of safety analyses

- redundant and emergency system operational experience

- demonstration of storage system integrity.

At all the operating facilities indicated above, dry storage operations have been successful, with low radiation doses and no serious operational problems. 
Dry Storage of High-Level Waste (HLW)

Experience with vaults for dry interim storage of vitrified HLW is relevant to spent fuel storage technology. A vault facility constructed at Marcoule, France, began operation in 1969. By 1973, 12 tonnes of vitrified waste were stored in metal canisters. A second vitrification campaign began in 1978; 680 SS containers filled with vitrified waste are being stored in air at Marcoule at $\sim 100^{\circ} \mathrm{C}$. A similar facility has been designed for construction at La Hague.

Dry Storage of Water Reactor Fuel

Programs in progress to demonstrate dry interim storage of irradiated Zircaloy-clad fuel assemblies are summarized below.

\begin{tabular}{|c|c|c|c|}
\hline Facility (a) & Type of Storage & $\begin{array}{c}\text { Date of } \\
\text { First } \\
\text { Storage }\end{array}$ & $\begin{array}{c}\text { Type } \\
\text { of Fuel } \\
\end{array}$ \\
\hline WNRE & Silo & 1975 & $W R-1$ (b) \\
\hline WNRE & Silo & 1976 & PHWR \\
\hline NTS (E-MAD) & Vault & 1979 & PWR \\
\hline NTS (E-MAD) & Silo & 1978 & PWR \\
\hline NTS (E-MAD) & Surface dry well & 1979 & PWR \\
\hline NTS $(C 1$ imax $)$ & Deep dry well & 1980 & PWR \\
\hline KW0 & R\&D test & $1981 / 82$ & PWR \\
\hline KWW & Metal cask & 1982 & BWR \\
\hline
\end{tabular}

(a) See glossary for definition of terms.

(b) $\mathrm{Zr}-2.5 \mathrm{Nb}$ cladding.

Four types of Zircaloy-clad fuel (at initial temperatures from 120 to $400^{\circ} \mathrm{C}$ ) are in demonstrations representing the four major dry storage concepts. Zircaloy-clad fuel from the Swiss DIORIT test reactor is expected to be placed in metal cask storage late in 1982 . The construction licenses have been granted for an away-from-reactor (AFR) facility for LWR fuel (1500 tU) at the Gorleben site in the Federal Republic of Germany; construction is in progress. 
Hot Cell and Laboratory Tests

Dry storage demonstrations with full LWR assemblies provide evaluations under prototypic conditions and improve the statistical base. In addition, several organizations are conducting testing programs that address specific phenomena, such as cladding mechanical behavior, stress corrosion cracking (SCC), and fuel oxidation. For example:

- Tests on whole irradiated PWR rods were conducted by the U.S. Department of Energy (DOE)/Hanford Engineering Development Laboratory (HEDL)/Battelle Columbus Laboratories (BCL) at 480 to $570^{\circ} \mathrm{C}$. Additional tests are planned at $325^{\circ} \mathrm{C}$.

- Other DOE tests are planned on defective and intact BWR and PWR fuel rods under nomal and abnomial storage conditions.

- The U.S. Nuclear Regulatory Commission (NRC) is planning whole rod furnace tests on BWR and PWR rods.

- The Tennessee Valley Authority (TVA) and the Electric Power Research Institute (EPRI) are developing a program to investigate fuel oxidation at cladding defects.

- The German Ministry of Research and Technology is sponsoring furnace tests on 14 BWR and 9 PWR rods at Ispra, Italy, at temperatures up to $400^{\circ} \mathrm{C}$.

- CANDU (PHNR) fuel with intact and defective cladding is undergoing tests in moist and dry air at $150^{\circ} \mathrm{C}$.

Other tests that are being conducted are summarized in the report. The combination of specific tests with irradiated rods and prototypic demonstrations with irradiated assemblies addresses recognized phenomena and provides for definition of unexpected behavior. Together, the approaches are developing a data base to 1 icense dry storage of water reactor fuel.

VERIFICATION OF FUEL INTEGRITY UNDER DRY STORAGE CONDITIONS

Zircaloy-clad fuel rods were inspected at BCL after up to 6 months in 1 imited air and inert gas at temperatures from 480 to $570^{\circ} \mathrm{C}$. The inspections and 
the absence of ${ }^{85} \mathrm{Kr}$ in the furnace cover gases indicated that no cladding failures had occurred. Zircaloy-clad fuel rods exposed in a furnace test at Ispra, Italy, were inspected after about 9 months at 100 to $400^{\circ} \mathrm{C}$ ( 6 months of the test were at $400^{\circ} \mathrm{C}$ ). Interim inspections and cover gas analyses suggest that no cladding failures have developed. At the Nevada Test Site (NTS), the cover gases of seven fuel assemblies were sampled after exposure in dry storage tests; no evidence of cladding failure was observed. A PWR assembly was inspected at the KWO reactor in the Federal Republic of Germany (FRG) after 60 days in moist $\mathrm{N}_{2}$ with no evidence of cladding failure. Numerous Zircaloyclad fuel assemblies that were shipped in dry casks by boat showed no evidence of cladding failure. The cask atmospheres were monitored at the receiving sites after dry residences of 2 to 3 months at estimated temperatures up to $450^{\circ} \mathrm{C}$.

At the Oak Ridge National Laboratory (ORNL), however, sensitized stainless steel GCR fuel rods degraded during storage in moist air. During a dry shipment of LWR fuel with known reactor-induced defects (SS cladding), radioactive species were released inside the shipping cask. The release appears to have been promoted by a reaction between the oxygen in the air cover gas and the $\mathrm{UO}_{2}$ fue 1 that was exposed at the cladding defects. Hot cell tests in Canada on defective Zircaloy-clad fuel rods demonstrated that fuel oxidation can cause a fuel volume increase $\left(\mathrm{UO}_{2} \rightarrow \mathrm{U}_{3} \mathrm{O}_{8}\right)$ if temperatures and oxidant levels are sufficiently high.

To date, there has been no evidence that Zircaloy-clad fuel has degraded during dry storage demonstrations. Additional fuel assembly and fue 1 rod examinations are scheduled in the next 1 to 2 yr for dry storage demonstrations and whole rod tests in Canada, the Federal Republic of Germany, and the United States.

DRY STORAGE REGIMES

Due to relatively low burnups and extended wet storage, much of the Canadian CANDU fuel $\mathrm{c}$ an be stored at low temperatures $\left(<150^{\circ} \mathrm{C}\right)$. Most of the older European and Japanese fuel, however, has been shipped to reprocessing plants; and remaining fuel has relatively high heat ratings. Thus, European 
tests are being conducted at maximum cladding temperatures of 300 to $400^{\circ} \mathrm{C}$. Because no U.S. commercial fuel has been reprocessed since 1971, much of the U.S. inventory has low heat ratings, which provides flexibility in choosing dry storage temperature regimes that includes the prospects to store consolidated fuel (rods reconstituted into a close-packed array to better utilize storage space).

Tests at the upper end of the expected storage temperature range involve inert cover gases for Zircaloy-clad fuel. In the intermediate and lower temperature regimes, there is interest in qualifying LWR fuel for storage in air to minimize monitoring requirements. Demonstrations and testing programs have been designed to establish maximum cladding temperatures in inert and oxidizing cover gases.

\section{CHARACTERISTICS OF THE STORED WATER REACTOR FUEL INVENTORY}

Selection of fuel and dry storage testing conditions must address the range of water reactor fuel characteristics, including the followi considerations:

- Zircaloy-c lad fuel represents $>95 \%$ of the U.S. LWR inventory; the remainder is clad with stainless steel. There are only three U.S. LWRs and two LWRs outside the United States that cont inue to operate with SS-clad fuel.

- By 1986, several thousand U.S. LWR assemblies will have heat ratings below $0.3 \mathrm{~kW} /$ assembly, suggesting that they can be stored at relatively low temperatures.

- Although older LWR fuel has more rods with cladding defects, rolatively low anticipated dry storage temperatures may mitigate their effects (for example, the oxidation of exposed $\mathrm{UO}_{2}$ ).

- 01der LWR fuel was not prepressurized. Since the early 1970s, PWR fuel has been prepressurized; since the late 1970s, BWR fuel has been prepressurized but at lower pressures than PWR fuel. Fission gas releases increase the total internal fuel rod pressures. 
- Radioactive oxide deposits (crud) develop on fuel rod surfaces during reactor operation. Behavior of the deposits during dry storage affects fuel retrieval and storage system decommissioning, and crud emissivities must be accounted for in radiative heat transfer.

- Reactor radiation increases cladding strength and decreases ductility. At sufficient combinations of time and temperature the radiation effects tend to anneal; therefore, the consequences of annealing must be considered in dry storage demonstrations and tests.

\section{STORAGE SYSTEM INTEGRITY}

Operational problems in vaults and dry wells have been minor after up to $18 \mathrm{yr}$ of operation (in 1982); and $7 \mathrm{yr}$ of silo experience suggests that decades of satisfactory operation $c$ an be expected. Demonstration tests with irradiated fuel in metal storage casks are just beginning, but metal shipping casks with mild steel chambers have been used since the mid-1940s. Metal storage/shipping casks have succes sfully survived fire, drop, and crash tests. If metal casks are used only for storage, qualification tests for transportation accidents would not be required.

\section{INTERFACING INTERIM STORAGE WITH SUBSEQUENT FUEL OPERATIONS}

Interim storage developments should consider, where practical, measures that will simplify future fuel management operations (reprocessing and/or geologic disposal). For example, if fuel is to be placed in metal canisters for dry storage, the proper selection of canister materials and conf igurations may preclude a need to remove the fuel from the canister in future operations. However, efforts to interf ace with future operations also must consider impacts on current plant operations.

\section{CONCLUSIONS}

The information presented in this report leads to the following conclusions: 
- All types of irradiated nuclear fuel have been shipped and handled under dry conditions. Dry fuel handling experience dates back to early reactor operation in the mid-1940s. Operations and phenomena relating to fuel handling under dry conditions are highly familiar.

- Dry interim storage is a familiar technology, and licensed facilities exist for certain fuel types in countries outside the United States. LMFBR fuel has been stored in vaults and dry wells in the United States, and GCR fuel is stored in several vaults and dry wells in the United States and in vaults in the United Kingdom.

- Dry storage demonstrations fueled with irradiated Zircaloy-clad assemblies are under way in several countries; dry wells, metal casks, silos, and vaults are being demonstrated. Some assemblies with zirconium alloy cladding have been in dry storage since 1975 . Cladding temperatures have ranged from 40 to $400^{\circ} \mathrm{C}$ in demonstrations and up to $570^{\circ} \mathrm{C}$ in hot cell furnace tests. Wet storage times prior to dry storage have ranged from 4 months to $4 \mathrm{yr}$. Zircaloy-clad BWR, organic-cooled reactor (OCR), (a) pressurized heavy-water reactor (PHWR), and PWR fuel assemblies are currently residing in dry storage demonstrations. This experience represents a broad range of conditions; however, fuel behavior in one temperature regime should not be construed to apply to other regimes.

- Experience is available for air, argon, carbon dioxide, helium, and nitrogen cover gases, including monitoring and impurity control of inert gas systems.

- Both canistered and uncanistered Zircaloy-clad fuel is being tested.

- Hot cell and 1aboratory tests are addressing specific phenomena, including cladding mechanical and currosion behavior and crud effects.

(a) $2 r-2.5 \mathrm{Nb}$ cladding. 
- The scopes of current and future demonstrations and specific tests that have been carried out so far appear satisfactory to establish licensing boundaries for dry storage of water reactor fue 1 , provided that attention is given to heat transfer benchmarking and fuel integrity verification.

- To date, the performance of all four dry storage concepts has been safe, technically sound, and capable of operation with relatively low radiation fields in work areas.

- To date, nothing in the behavior of Zircaloy-clad fuel under dry storage conditions has suggested any barrier to successful use of dry interim storage.

- Long cooling times for large fractions of Canadian and U.S. fuel inventories offer prospects for relatively low storage temperatures by proper fuel selection. Some countries have LWR fuel inventories with relatively short storage times, which will require preparations to store fuel at higher temperatures. Some U.S. utilities miay also need to store fuel at higher initial temperatures, particularly if dry storage of consolidated fuel is licensed.

- Storage system integrity is not expected to present major problems, based on available experience. However, storage system integrity should continue to be addressed in technology studies.

- Interim storage developments should consider, where practical, measures that will simplify future fuel management operations (reprocessing and/or geologic disposal). However, the impact of storage procedures on power plant operations will probably be the principal consideration. 


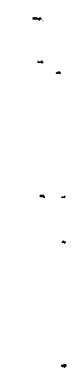




\section{CONTENTS}

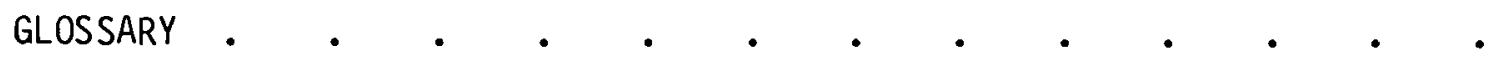

ACKNOWLEDGMENTS

ABSTRACT

SUMMARY AND CONCLUSIONS

INTRODUCT ION

DRY STORAGE CONCEPTS

TYPES OF DRY INTERIM STORAGE FACILITIES •

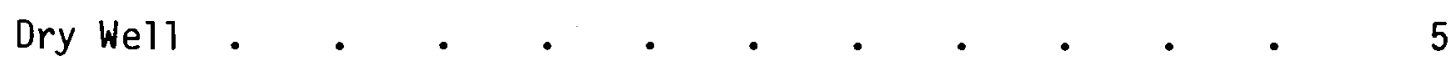

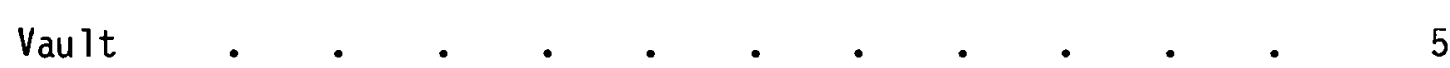

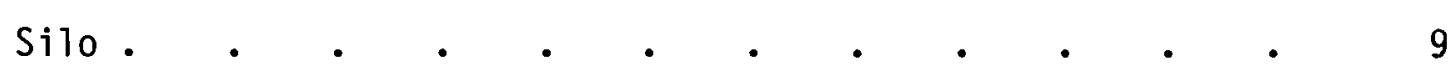

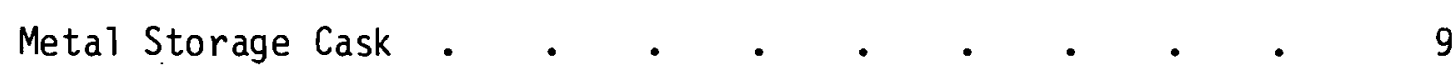

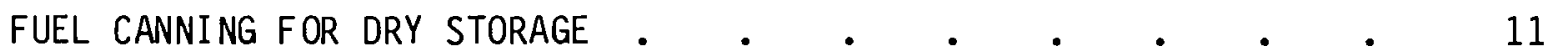

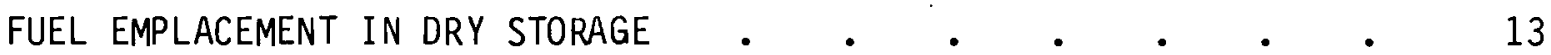

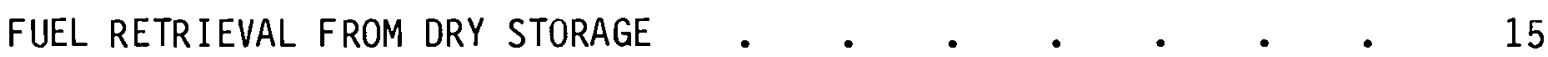

INTERFACING INTERIM STORAGE WITH SUBSEQUENT FUEL OPERATIONS • • 15

DRY STORAGE CONCEPTS IN WASTE MANAGEMENT SCENARIOS $\quad$ • $\quad$ • 16

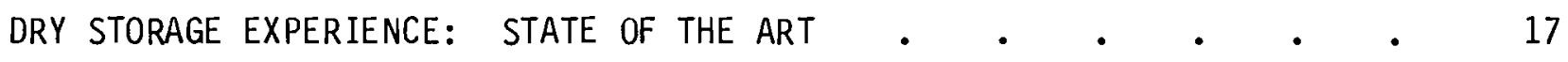

HISTORICAL ASPECTS OF IRRADIATED FUEL HANDLING UNDER

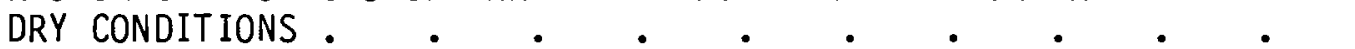

DATA BASE FOR DRY STORAGE OF NON-ZIRCALOY-CLAD (GCR AND

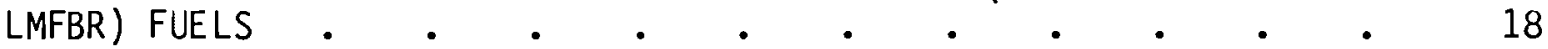

DATA BASE FOR DRY STORAGE OF ZIRCALOY-CLAD FUEL • • • • • 18

Dry Storage Demonstrations: Irradiated Fuel Assemblies $\quad 19$

Dry Storage Demonstrations: Electrically Heated Assemblies . 24

Hot Cell and Laboratory Studies: Zircaloy-Clad Fuel Rods . 25 
Verification of Zircaloy Cladding Integrity in Dry

Storage • . . . . . . . . . . 26

CHARACTERISTICS OF EXISTING DRY STORAGE FACILITIES $\quad$ • $\quad$ • $\quad$ • 29

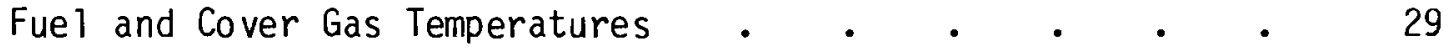

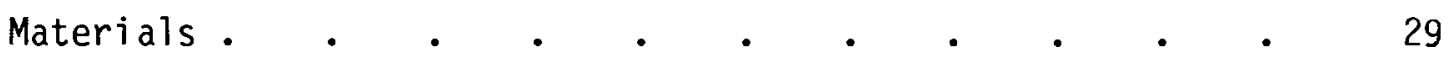

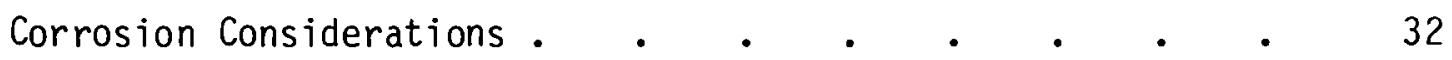

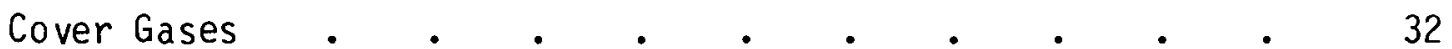

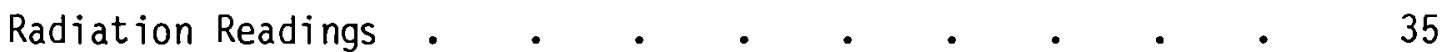

Monitoring System Integrity . $\quad$ • . . • . . 35

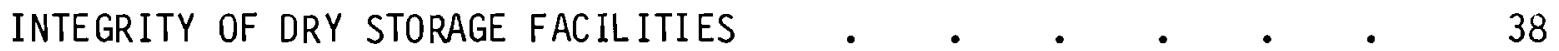

Dry Wells, Vaults, and Silos • . . . . . . . . 38

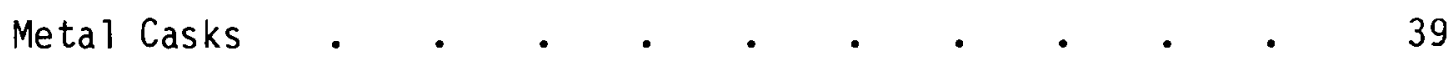

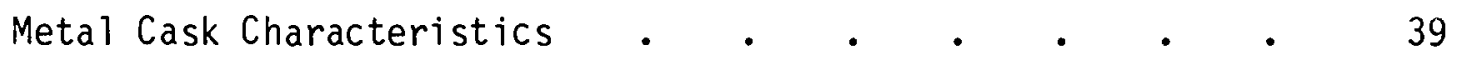

Shipping Cask Safety Testing . . . . . . . 42

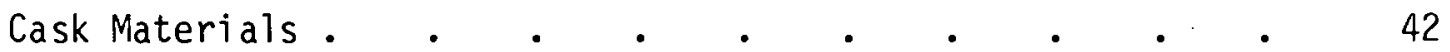

Decomissioning Aspects of Dry Storage Facilities . $\quad$ • 44

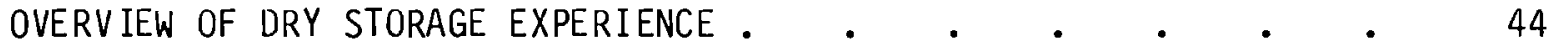

ASSUMPTIONS REGARDING SPENT FUEL AND DRY STORAGE CONDITIONS • • • • 47

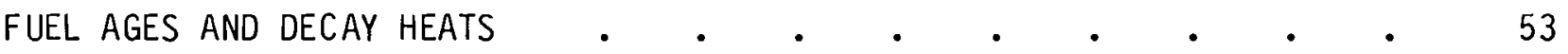

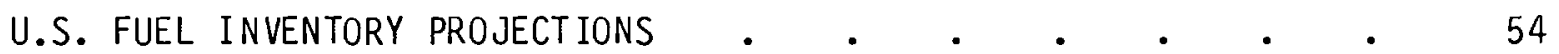

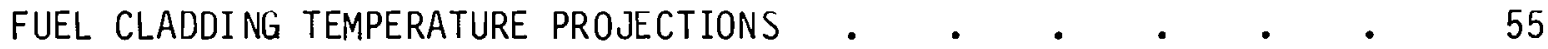

FACTORS INFLUENCING FUEL ASSEMBLY PERFORMANCE IN DRY STORAGE $\quad$ • • 57

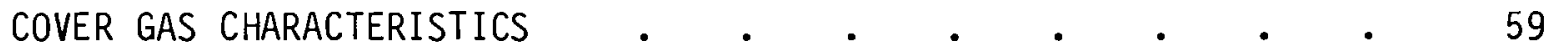

FUEL OXIDATION •

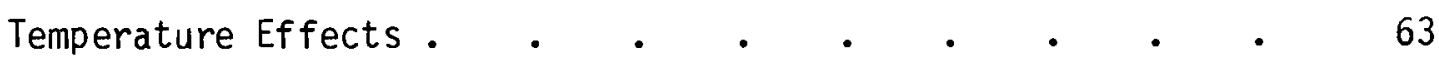

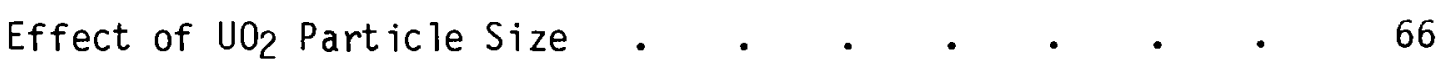


Effects of Cover Gas Composition . . . . . . . 66

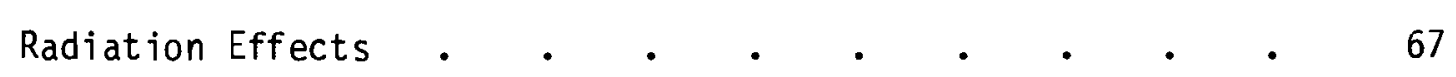

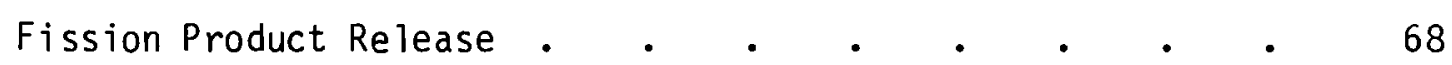

CLADDING OXIDATION

Oxidation Under Normal Dry Storage Conditions $\quad$ • $\quad$ • 70

Oxidation Under Abnomal Dry Storage Conditions . . . 71

Fuel Rod Behavior During Temperature Excursions • • • 71

DECAY HEAT CHARACTERISTICS OF SPENT FUEL $\quad$ • $\quad$ • $\quad$ • $\quad$ • $\quad$ • 75

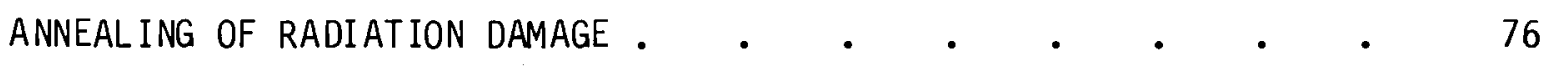

STRAIN RATE EFFECTS •

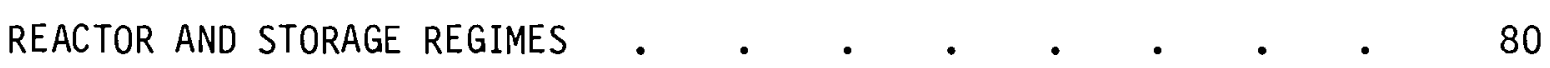

ZIRCALOY STRESS CORROSION CRACKING • • • • • • • • • • $\quad$ • 85

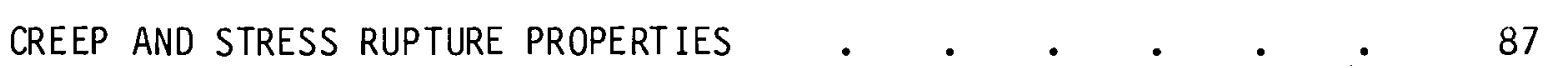

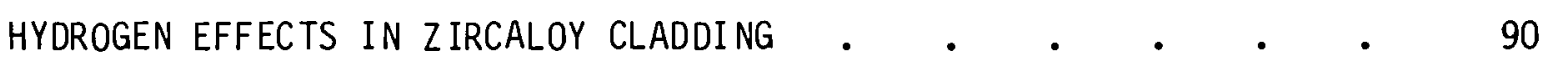

CHARACTERISTICS OF FUEL CRUD AND ITS POTENTIAL IMPACT ON

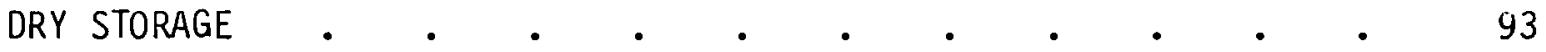

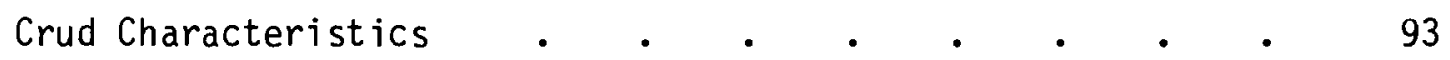

Crud Impacts on Dry Storage of Water Reactor Fuel . . . 95

TEMPERATURE-TIME CHARACTERISTICS OF ZIRCALOY-CLAD FUEL • • • • 97

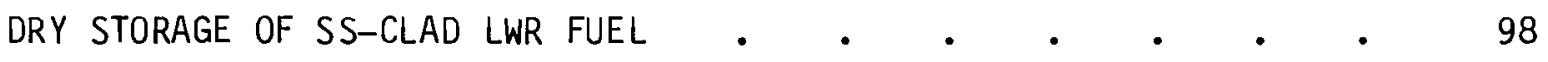

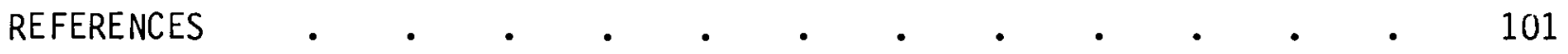

APPENDIX A - MULTIPLE TERMINOLOGIES USED IN DRY STORAGE TECHNOLOGY • A.1

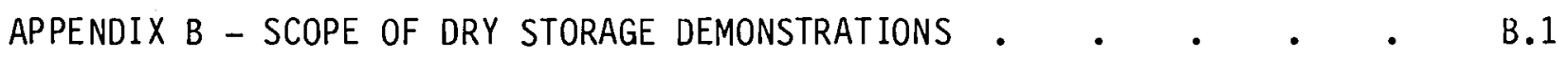

APPENDIX C - CHARACTERISTICS OF WATER REACTOR SPENT FUEL • • • • • C.1

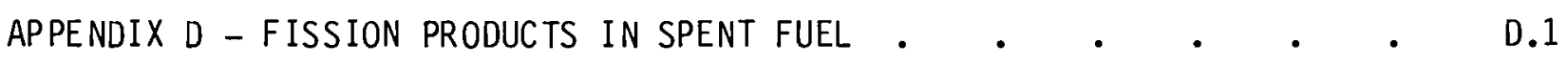




\section{FIGURES}

1 Near-Surface Dry Wells for Dry Storage of Spent Nuclear Fuel a 6

2 Subsurface Dry Wells for Dry Storage of Spent Nuclear Fuel • $\quad 7$

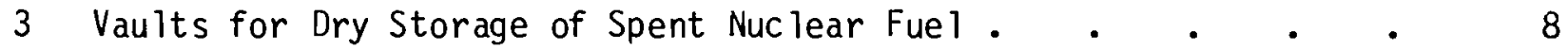

4 Silos for Dry Storage of Spent Nuclear Fuel $\quad$ - . $\quad$. $\quad$. 10

5 Metal Storage Casks for Dry Storage of Spent Nuclear Fuel • • 12

6 Main Hot Cell for Remote Receipt and Handling of Irradiated

Fuel Assemblies at E-MAD, Nevada Test Site . . . . . 14

$7 \quad$ Zircaloy-Clad Fuel Assembly Temperature Histories for Dry

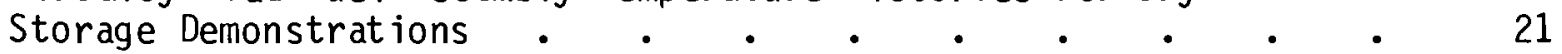

8 Mild Steel Shipping Cask for Irradiated Fuel . . . . . . 43

9 Distribution of Wet Storage Times for U.S. LWR Spent Fue 1

Inventories Discharged as of December 1980 and Projected

to 1986 •

10 Distribution of Decay Heats for U.S. LWR Spent Fuel Inventories

Discharged as of December 1980 and Projected to 1986 . 54

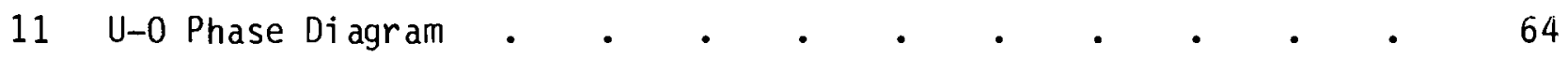

12 Time to Oxidize Unirradiated $\mathrm{UO}_{2}$ Pellets to $5 \% \mathrm{U}_{3} \mathrm{O}_{8}$ in $\mathrm{Air}$

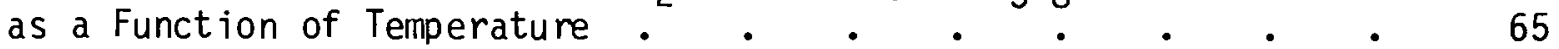

13 Corrosion of Preoxidized Zircaloy-2 (150 mg/dm²) at

1-atm Oxidant.

14 Comparison of Deformation of a PWR Fuel Rod That Failed in NRU

Experiment MT-3 with Predicted Deformation for PWR Rods . . 74

15 Decay Heats in Typical PWR and BWR Assemblies . . . . . 76

16 Isochronal Annea! ing Curve for Annealed Zircaloy-2

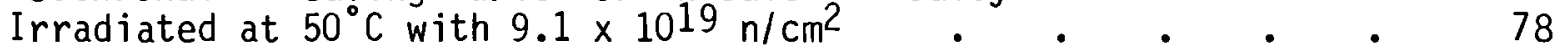

17 Strain Rate and Prior Irradiation Effects on SEAF . . . . 78

18 Comparison of Stress Rupture Results for Annealed Zircaloy-2 • 91

\begin{tabular}{l}
19 Comparison of Stress Rupture Results for Stress-Relieved \\
Zircaloy-2 \\
\hline
\end{tabular} 
C.1 Typical Geometries for a LWR Fuel Rod and BWR, PWR, and CANDU Fuel Assemblies . . . . . . .

C.2 Relationship of Fuel Crud Layer to Fuel Cladding and Fue 1 Cladding Oxide . . . . . . . . . C.15

D.1 Decay of Potentially Degrading Fission Products to $\mathrm{Cladding}$ Resistance to Stress Corrosion Cracking . . . . . . D.2 
1 Dry Storage of GCR and LMFBR Fuel • . . . . . . 19

2 Dry Storage Demonstrations of Zircaloy-Clad Fuel . . . . 20

3 Fuel Cladding Temperatures and Time in Pool Storage for Zircaloy-Clad Fuel in Dry Storage . • . • • . . . 21

4 Hot Cel1 and Laboratory Dry Storage Studies . . . . . 26

$5 \quad$ Cladding Integrity Verification for Zircaloy-Clad Fuel in Dry Storage Tests . . . . . . . . . . 28

6 Fuel and Cover Gas Temperatures at Dry Storage Facilities . . 30

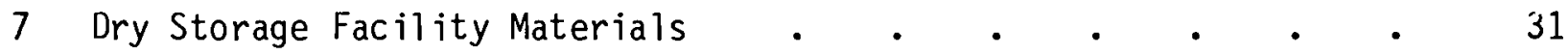

8 Corrosion Considerations for Dry Storage . . . . . 33

9 Cover Gases Used for Dry Storage . . . . . . . . . 34

10 Radiation Levels at Dry Storage Facilities . . . . . 36

11 Methods to Monitor Dry Storage System Integrity • • • • 37

12 Storage Cask Status . . . . . . . . . . . . 40

13 Costs and Properties of Candidate Cover Gases and Water Vapor . 59

14 Factors Affecting Fuel Rod Degradation . . . . . . 81

15 Comparison of Fuel Exposure Conditions . . . . . . . 83

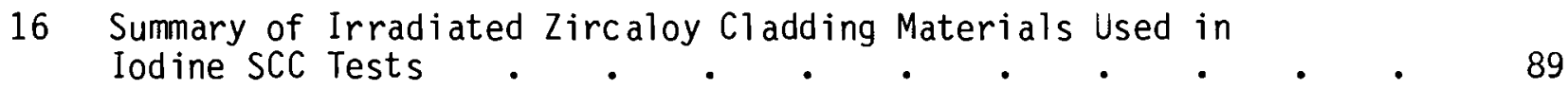

17 Terminal Solubilities for Hydrogen in Zircaloy as a . . . . 92

18 Activation and Fission Products Associated

with Crud Deposits . . . . . . . . . . 95

A.1 Parallel Terms Used for Dry Storage Technology . • • • A.1

B.1 Installations and Demonstration Tests for Dry Storage of
Irradiated Nuclear Fuel. . . . . . . . B.2

C.1 Major Fuel Assembly Parameters for LWR Fuel . . . . . . C. C.3 
C.2 Fuel Parameters for CANDU PHWR Fuel . . . . . . C C.6

C.3 Fuel Bundle Materials . . . . . . . . . . . C.8

C.4 Comparison of LWR and CANDU Decay Heat and Radioactivity . . C.11

C.5 Types and Characteristics of Fuel Failures in Water Reactor Fuel . C.12

C.6 Fuel Performance Parameters Observable by Poolside
Inspection Techniques . . . . . . . . C.14

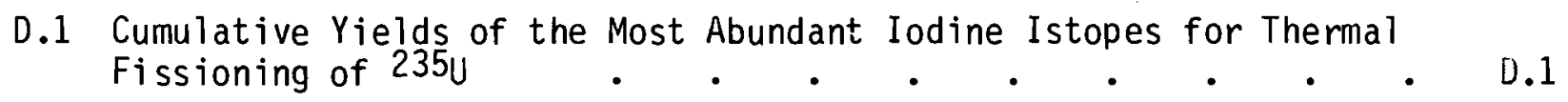

D.2 Concentrations of Fission Products from LWR Fuel at Discharge

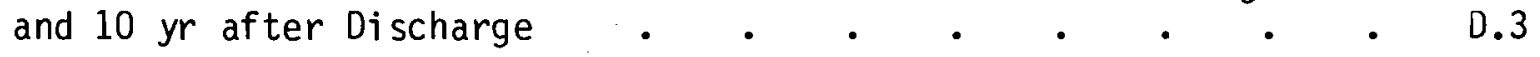




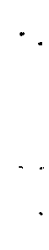




\section{INTRODUCTION}


INTRODUCTION

Extended interim storage of spent nuclear fuel will continue to fill an essential role in spent fuel management until final solutions for the disposition of the spent fuel have been decided and implemented. Currently, wet storage is the only licensed spent fuel management option in the United States. In 1977 the Carter administration imposed a moratorium on nuclear fuel reprocessing and attempted to develop federally administered storage of spent fue 1. More recently, the Reagan administration has taken a more favorable position towards reprocessing but has placed the responsibility for interim storage of spent fuel with utilities rather than with the federal government. Even in a favorable political climate, reprocessing is not likely to reduce the stored light-water reactor (LWR) inventory substantially in the United States for a decade or more. An alternative disposal method-retrievable geologic storage of unreprocessed spent fuel ${ }^{(a)}$--is also not expected to be available on a licensed basis until near the end of the century. (1)

Each nation with a nuclear power program must evaluate its own fuel management needs and decide how best to meet them, based on national policies and geographic, economic, and technological considerations. Several countries have elected to expand wet storage capacities to meet interim storage needs (for example, Argentina, France, Italy, and Sweden). Other countries are actively pursuing a combination of wet and dry storage technologies (Canada, Spain, the United Kingdom, and the United States). The Federal Republic of Germany (FRG) is principally emphasizing dry storage to expand fuel storage capacities. Some countries (for example, France, Japan, and Switzerland) are using dry storage to solve special storage needs that involve relatively small fuel inventories.

The characteristics of the fuel inventory enter strongly into the expected conditions for dry storage in a given country. In Canada, fuel burnups are relatively low $(5,000$ to $10,000 \mathrm{MWd} / \mathrm{tU})$, and a substantial fraction of the fue 1 has been in wet storage for a relatively long time. Consequently, fuel residual heats are low, resulting in fuel storage temperatures that are $120^{\circ} \mathrm{C}$ or

(a) In an uncertain energy future it is prudent to consider U.S. spent fuel as a potential energy source. 
lower in dry storage demonstrations. In Europe and Japan, most of the older LWR fuel has been shipped to reprocessing sites, leaving the at-reactor inventory with relatively short average storage times and high average decay heats. In the United States, no LWR fuel has been reprocessed since 1971; therefore, the U.S. LWR inventory has a wide range of storage times and decay heats. Some utilities, however, may move to license dry storage of consolidated fuel, which would result in higher storage temperatures.

In the United States, several reactors will require additional storage capacity as early as $1984-1986$; ${ }^{(a)}$ therefore, utilities are currently assessing storage options that could be implemented in time to avoid reactor shutdowns. Dry interim storage of spent nuclear fuel is one option being evaluated. While wet storage has proven both safe and successful, (2) dry storage has the following attractions: ${ }^{(3-7)}$

- Most dry storage concepts can be added in modules, thereby avoiding large front-end capital costs.

- Modular concepts can be developed in a relatively short time.

- Dry storage concepts can be passively cooled with no requirements for pumps or blowers, which precludes concerns regarding interruption of coolant flow.

- Dry storage facilities generally require less coolant treatment and monitoring than wet storage facilities.

- Dry storage facilities generate very little secondary radioactive waste during operation.

- Dry storage has the flexibility of multiple options that can meet the wide diversity of utility requirements.

Dry storage of LWR fuel is currently unlicensed in the United States, but demonstration programs involving Zircaloy-clad fuel are under way in Canada, $(3,4,7,8)$ the Federal Republic of Germany, $(4,9-13)$ and the United

(a) The 1984 date was issued in a recent (June 1982) U.S. Department of Energy (DOE) publication: Spent Fuel Storage Requirements, DOE/RL-82-1, Richland Operations Office, Richland, Washington. 
States. ${ }^{(4,14-19)}$ Metal cask storage of Zircaloy-clad test reactor fuel is expected to begin in Switzerland in 1982. (20) Dry storage systems for irradiated liquid metal fast breeder reactor (LMFBR) fuel have operated in the United States since 1964. (3) Licensed storage of Magnox gas-cooled reactor (GCR) fuel began in the United Kingdom in $1971^{(3,4,21)}$ and was recently instituted in Canada for WR-1 fuel. This experience is valuable for the development of licensed dry storage facilities for water reactor fuel.

Pacific Northwest Laboratory (PNL) ${ }^{(a)}$ has conducted a review of the behavior of spent nuclear fuel and storage system components in dry interim storage. The results of the review are presented in this report, which includes information on:

- dry storage concepts

- dry storage experience in operating facilities

- assumptions regarding spent fuel and dry storage conditions for water reactor fue 1

- fuel ages and decay heats of water reactor fuel

- actual and expected behavior of water reactor fuel in dry storage.

(a) Operated for the U.S. DOE by Battelle Memorial Institute. 


\section{DRY STORAGE CONCEPTS}


DRY STORAGE CONCEPTS

This section provides a brief review of dry storage concepts; more detailed concept descriptions are referenced. Fuel canning, emplacement, and retrieval are also discussed.

\section{TYPES OF DRY INTERIM STORAGE FACILITIES}

Four types of facilities have been constructed for dry interim storage of spent nuclear fuel. All four facilities are in use and store several types of irradiated nuclear fuel. Multiple terms have evolved for these dry storage facilities; Appendix A discusses the various terms that are being used. In this report, the following terms will be used to identify the facilities:

- dry well

- vault

- silo

- metal storage cask.

Dry Well (caisson)

Dry wells are cylindrical holes in the ground that are lined with concrete and/or metal. Dry wells may be placed just below the surface of the ground (see Figure 1) or in rock tunnels far below the surface (see Figure 2). The fuel is stored inside sealed metal canisters. Major assessments of dry well technology and costs have been published. $(3,5,0,22)$ Heat is conducted from the stored fuel through the liner and the surrounding earth. Shield plugs, the soil, and the concrete structure provide shielding, resulting in low radiation levels above the dry wel1. Use of dry wells for storage of irradiated fuel began in 1964 at the Idaho National Engineering Laboratory (INEL), Idaho Fa11s, Idaho. Irradiated test reactor fuel was exposed in dry wells in a salt vault in Kansas from 1965 to 1967.

Vault (canyon, store, bay)

The vault storage concept involves a concrete bay (see Figure 3 ) where fuel is stored in sealed canisters or in baskets with tubes that are open to the storage bay. Cooling may be by natural or forced draft. To date the 


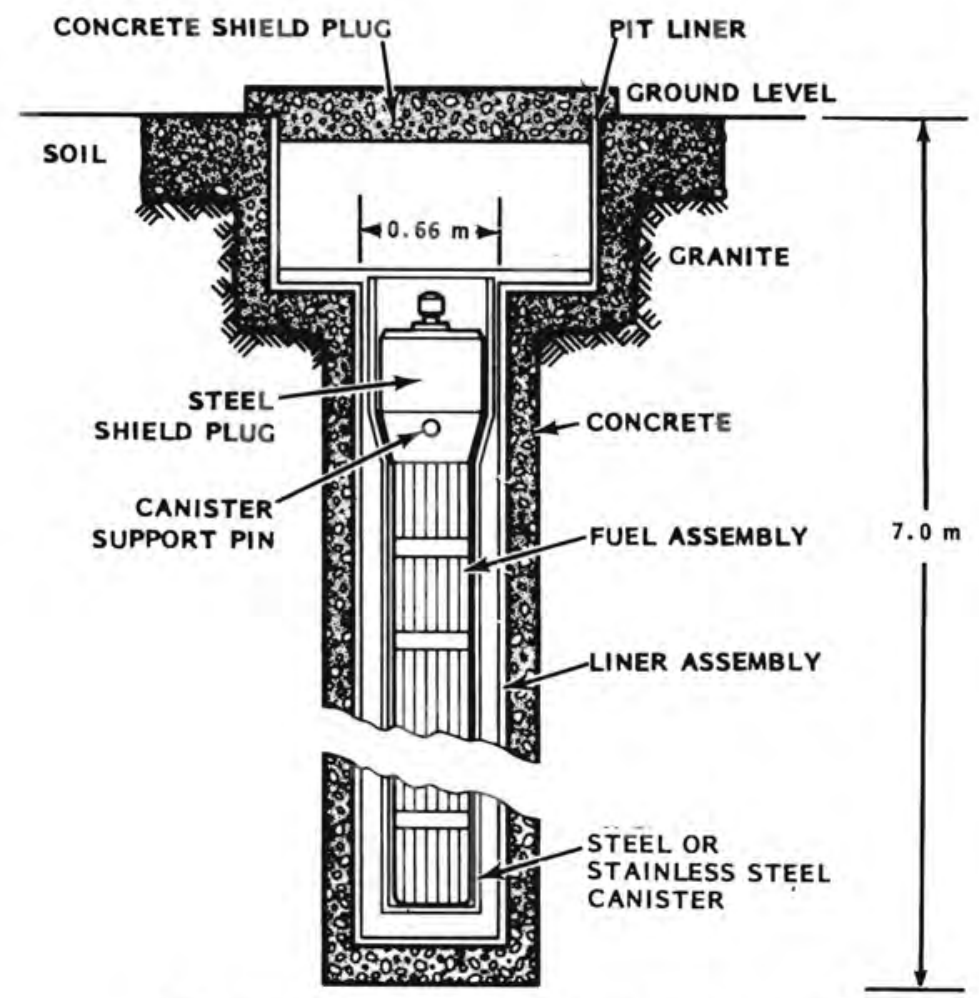

a) Schematic of Near-Surface Dry We11

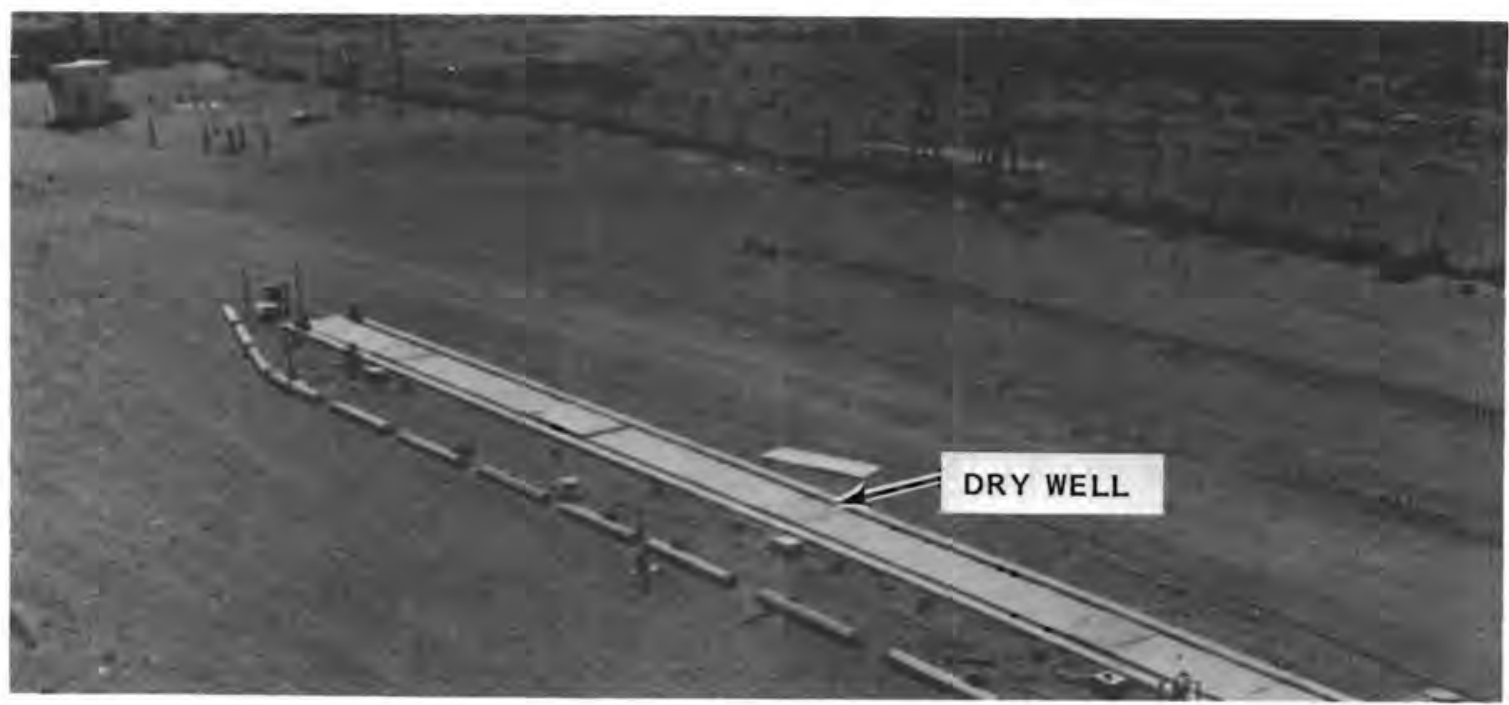

Neg. 82B905-7

b) Four Near-Surface Dry Wells at E-MAD, Nevada Test Site. Each dry well stores one irradiated PWR ássembly (photograph courtesy of DOE Nevada Operations Office)

FIGURE 1. Near-Surface Dry Wells for Dry Storage of Spent Nuclear Fuel 


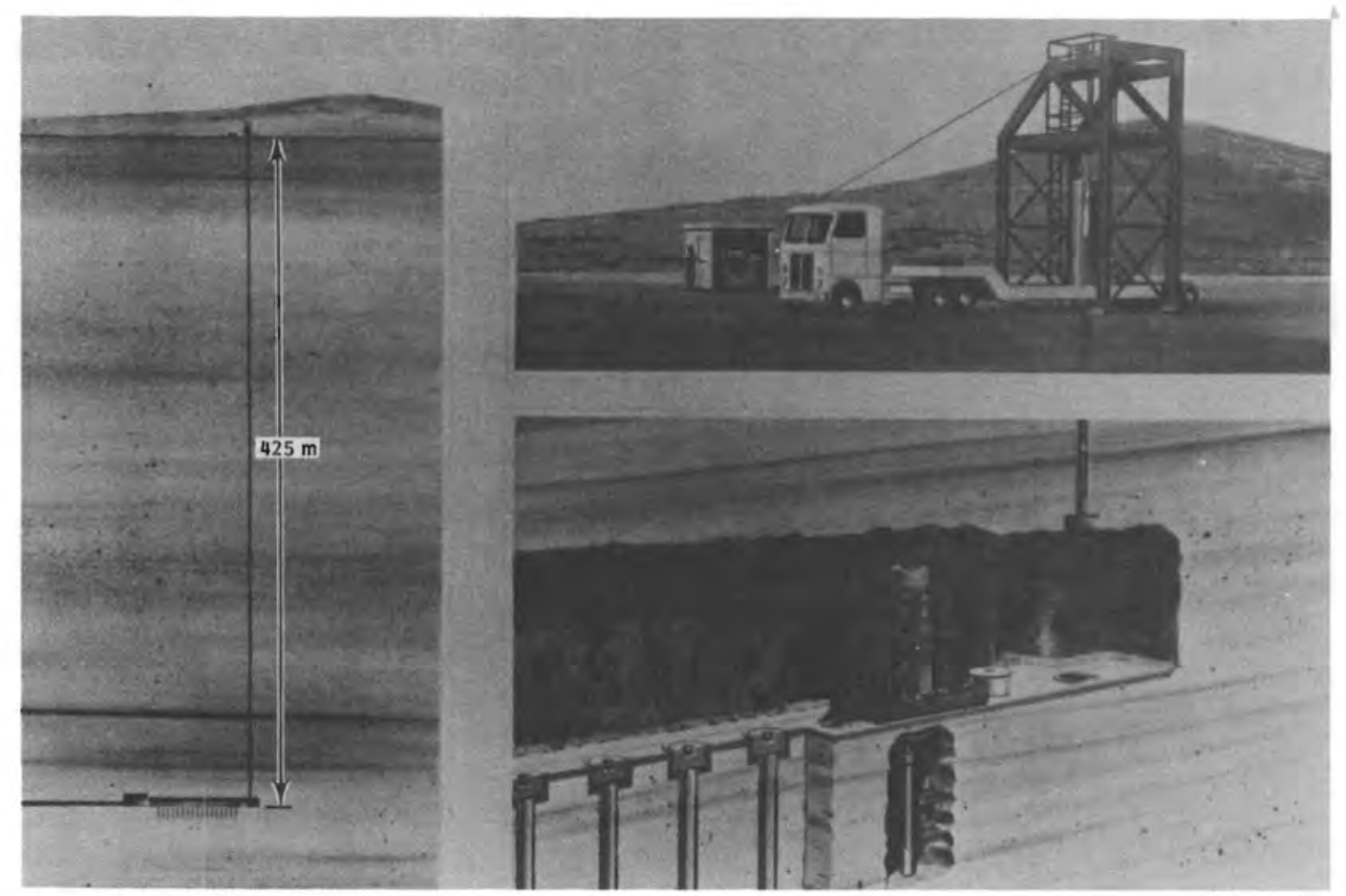

Neg. 82B905-6

a) Schematic of Subsurface Dry Wells at Nevada Test Site

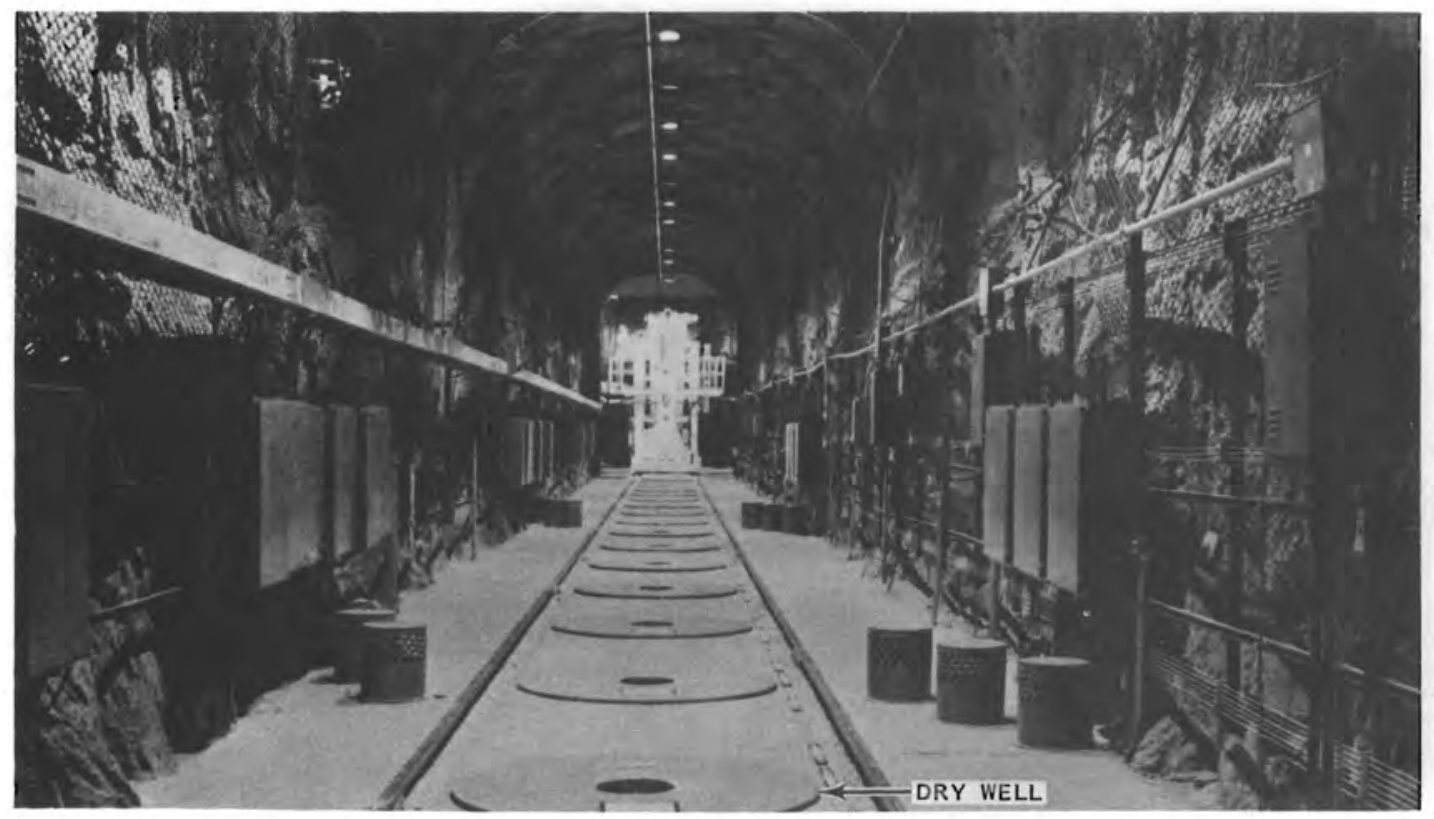

Neg. 82B905-5

b) Subsurface Dry Wells in Granite Chamber Storing 11 Irradiated PWR Assemblies; Canister Handling Machine Shown at Far End

FIGURE 2. Subsurface Dry Wells for Dry Storage of Spent Nuclear Fuel (courtesy of DOE Nevada Operations Office) 


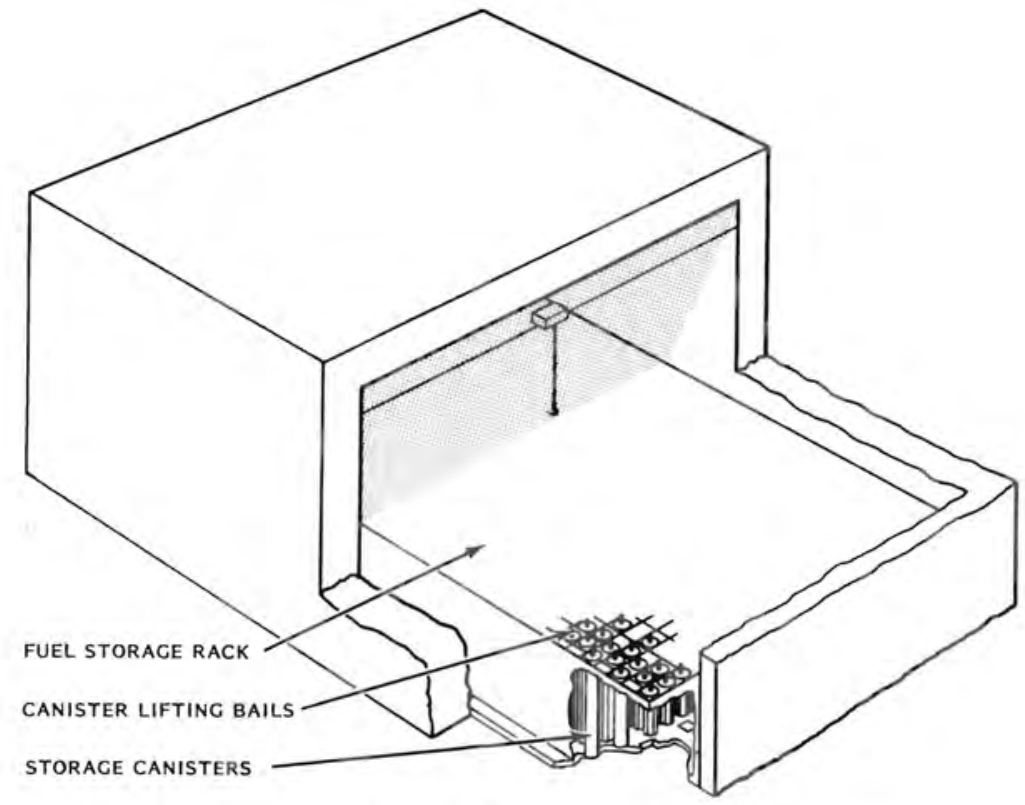

a) Schematic of Dry Storage Vault

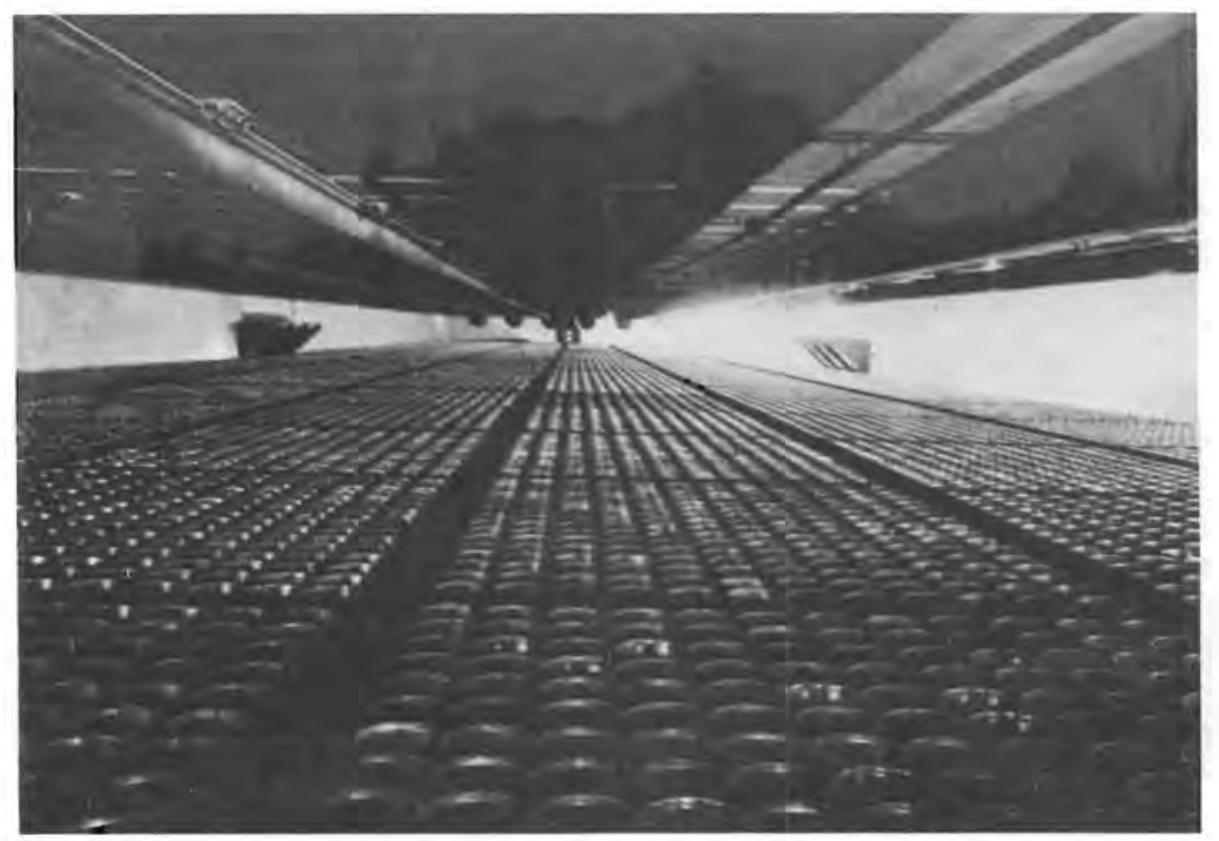

Neg. 82B905-3

b) Vault Storage of Magnox Fuel at Wylfa, Wales (view shows open-ended fuel storage tubes) (courtesy of C. J. Ealing, GEC Energy Systems, Ltd.)

FIGURE 3. Vaults for Dry Storage of Spent Nuclear Fuel 
fueled vault facilities have used air, argon, or carbon dioxide cover gases.

In some vaults the cover gas is recirculated; vaults where fuel is isolated from the cover gas operate in a once-through mode. In both cases, the cover gas passes through filters and is monitored for temperature and radiation. The oxidant level $\left(\mathrm{O}_{2}\right.$ and $\left.\mathrm{H}_{2} \mathrm{O}\right)$ is also monitored in the cover gas of some vaults, and the impurity levels are controlled. Vault cover gases are maintained below atmospheric pressure to ensure that leakage flows inward. Radiation shielding is ensured by concrete walls up to $6 \mathrm{ft}(2 \mathrm{~m})$ thick. The vaults are designed for seismic events, tornadoes, air crashes, etc. Since flammable and explosive materials are excluded from the designs, fire is extremely unlikely. The vaults are locked and under 24-h guard.

The Modrex ${ }^{(23)}$ and modular dry storage (MDS) ${ }^{(24)}$ conceptual designs are variations on the vault storage concept. They can be implemented as modules, thereby avoiding major front-end capital costs.

The Hot Fuel Examination Facility/South (HFEF/S) at INEL began temporary storage of LMFBR fuel in 1964. The first vault for extended dry storage of irradiated fuel began operation in 1971 at the Idaho Chemical Processing Plant (ICPP). Details regarding vault concepts and costs are provided in other publications. $(3,4-6,21,23-25)$

Silo (surface caisson, surface cask, concrete canister)

Silos are above-ground concrete structures of circular or square cross section that store irradiated fuel in sealed metal canisters (see Figure 4). Two silo designs are in use: one involves heat conduction through the concrete walls and one involves convection over sealed metal canisters inside the concrete silo. Thick concrete walls and top shield plugs limit radiation to low levels. Electrically heated silos began operation in Canada in $1974(3,25)$ and at Hanford in 1976. The first silo storage of irradiated fuel began in Canada in 1975. Details regarding silo technology and costs have been pub1 ished. $(3,5,6,23,25)$

\section{Metal Storage Cask}

Metal storage cask technology is an extension of the extensive experience with metal shipping casks. Zircaloy-clad water reactor fuel has been shipped in passively cooled metal casks for $15 \mathrm{yr}$.

(11) Metal shipping casks have 


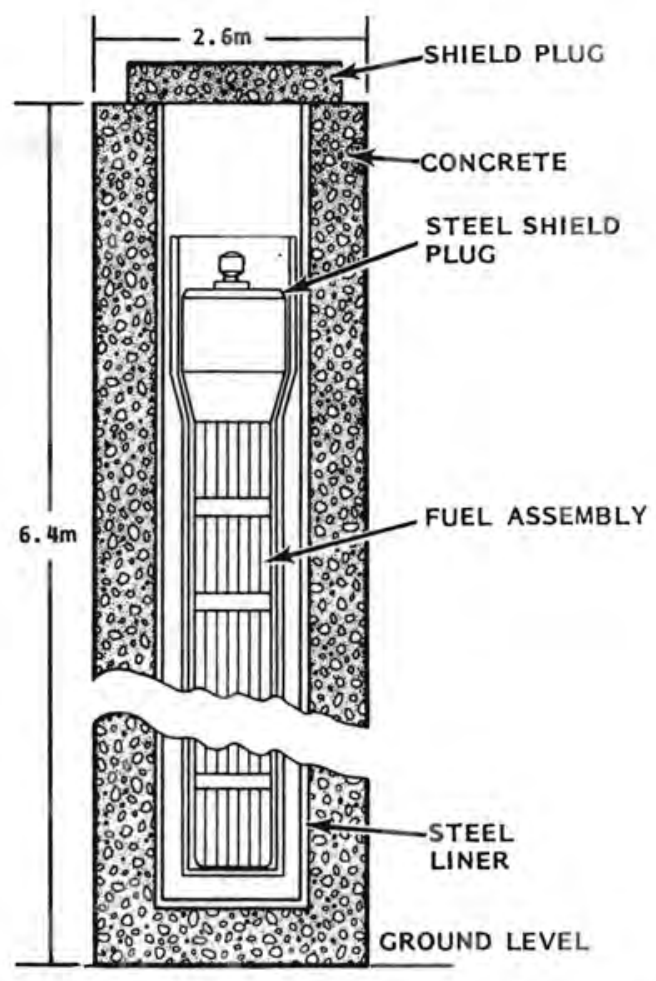

a) Schematic of Silo for Dry Storage of a PWR Fuel Assembly

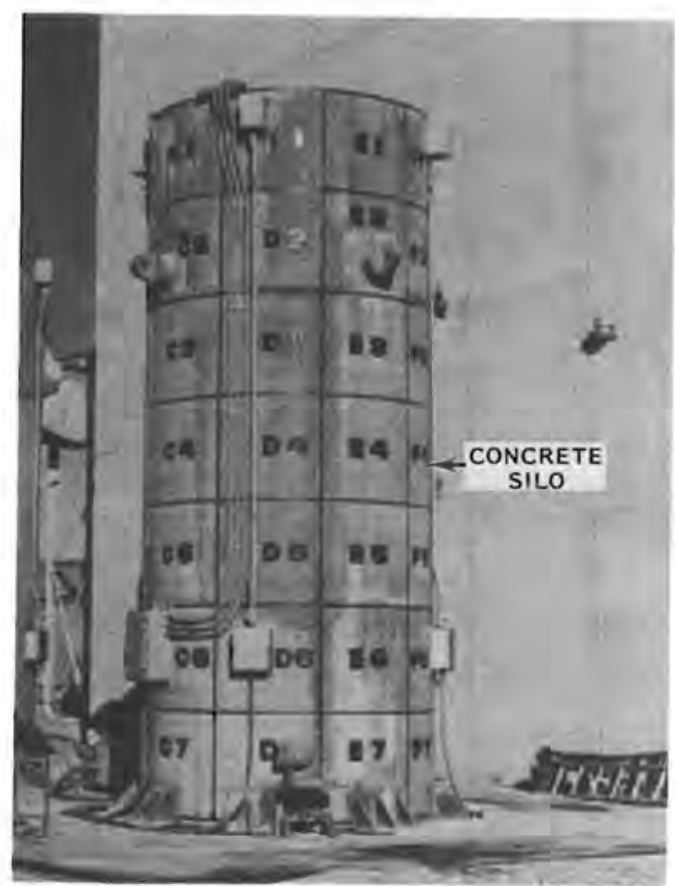

Neg. 82B905-8

b) Concrete Silo at E-MAD, Nevada Test Site; Stores One Irradiated PWR Assembly (courtesy of DOE Nevada Operations)

FIGURE 4. Silos for Dry Storage of Spent Nuclear Fuel 
been used for other types of fuel since the mid-1940s. Nodular iron casks were developed and have been licensed for both shipping and storage demonstration in the Federal Republic of Germany. The first storage of irradiated fuel in a metal cask began at the Kernkraftwerk Wuergassen (KWW) boiling water reactor (BWR) early in 1982. (9) Figure 5 a shows the CASTOR 1C metal cask of the type used at KWW; the cask holds 16 BWR assemblies. The first U.S. dry storage cask is under construction and is designed to store 24 pressurized water reactor (PWR) (see Figure 5b) or 52 BWR assemblies. The cask is designed for shipping with specially constructed impact limiters.

Single-failure-proof cranes(a) of ample capacity must be available to handle the large storage casks (see Table 12 in a later section for cask weights). Several U.S. reactors have upgraded their cranes to single-failureproof status.

FUEL CANNING FOR DRY STORAGE

Canning involves insertion of a fuel assembly inside a metal container (canister) to isolate it from direct contact with the storage environment. (3) Fue 1 has been canned for both wet and dry storage. Spent fuel is canned before being placed in certain dry wells, silos, or vaults; but current plans do not call for canning LWR fuel for cask storage. Arguments in favor of canning for cask storage center on the addition of another barrier to the storage system and containment of crud loosened during dry storage. Arguments against canning include: increased costs and fuel handling for canning and decanning; possible decreases in the number of assemblies per cask; disposal and/or decontamination of radioactive canisters; more complex heat transfer assessments; and some increase in fuel temperature. Because fuel retrievability will almost certainly be a requirement (see Fuel Retrieval from Dry Storage section), cladding degradation inside a canister would have possible impacts when the fuel is retrieved. Therefore, licensing agencies are still likely to require demonstration that the cladding is not expected to degrade during storage, even if the fuel is canned.

(a) Cranes that will not drop the load if any crane component fails. 


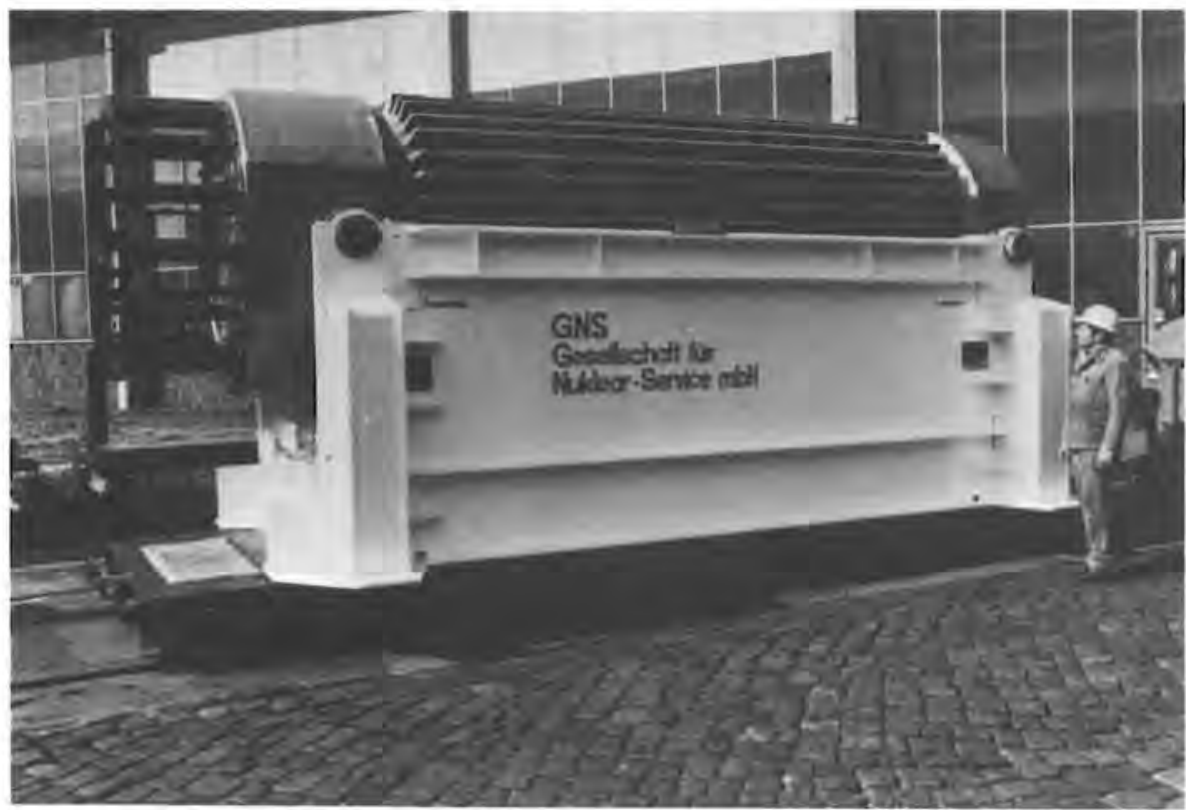

Neg. 82C010-1

a) GNS CASTOR 1C Netal Shipping/Storage Cask of the Same Type Used to Store 16 BwR Assemblies at KWW Reactor (FRG) (courtesy of J. D. Rollins, GNS)

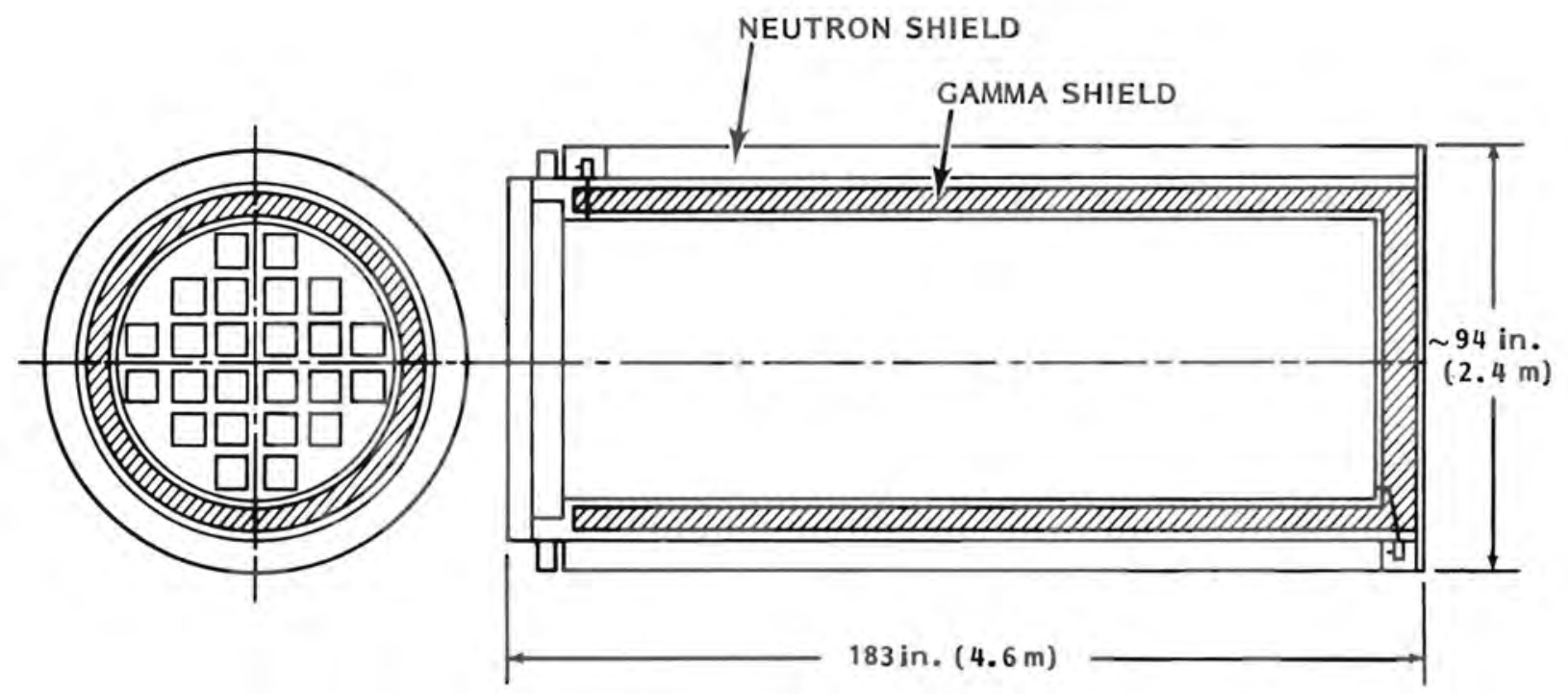

b) Schematic of Metal Storage Cask for Storing PWR Fuel (based on Ridihalgh, Eggers, and Associates, Inc., design)

FIGURE 5. Metal Storage Casks for Dry Storage of Spent Nuclear Fuel 
In Figure 6, a stainless steel (SS) canister containing an irradiated PWR assembly is being placed into a shielded transporter. The assembly was removed from wet storage and then loaded into the dry canister in a hot cell. Magnox fue 1, however, is stored in baskets having tubes that are open to the storage bay. The Tennessee Valley Authority (TVA) and GEC Energy Systems, Ltd., have investigated a vault for storing LWR fuel that would also use the open basket concept. (26) The fuel assemblies would be open to a connecting plenum of relatively small volume. In some cases, fuel has been canned at the reactor; in other cases, canning occurs at the storage facility. For at-reactor storage of LWR fuel, the fuel would probably be canned in the reactor pool, ${ }^{(6)}$ followed by drying of the interior of the canister.

\section{FUEL EMPLACEMENT IN DRY STORAGE}

Fuel is placed into dry wells using a shielded transporter. $(3,6,18)$ The canned fuel assembly is carried to the storage site in the transporter; the transporter is positioned over the storage hole; the fuel assembly is lowered into the dry wel1; and the dry well is closed with a shield plug. Irradiated fuel has been successfully emplaced into dry wells at the Nevada Test Site (NTS) and INEL. (3)

Fuel was placed into a silo inside a large hot cell at E-MAD(a) using a crane; the silo was then moved to an open-air site on a transporter. (27) At the Whiteshell Nuclear Research Establishment (WNRE), silos were loaded with irradiated fuel at the open-air storage location using cranes. ${ }^{(3)}$

Fuel has been placed into vaults by the following methods:

- with a crane at the Irradiated Fuel Storage Facility (IFSF) at INEL

- with a cask cart and grapple at the HFEF at INEL

- with a transfer machine and transporter at Wylfa, Wales.

other references ${ }^{(6,22)}$ have additional details regarding fuel emplacement.

(a) E-MAD - Engine-Maintenance Assembly and Disassembly hot cell facility, NTS. 


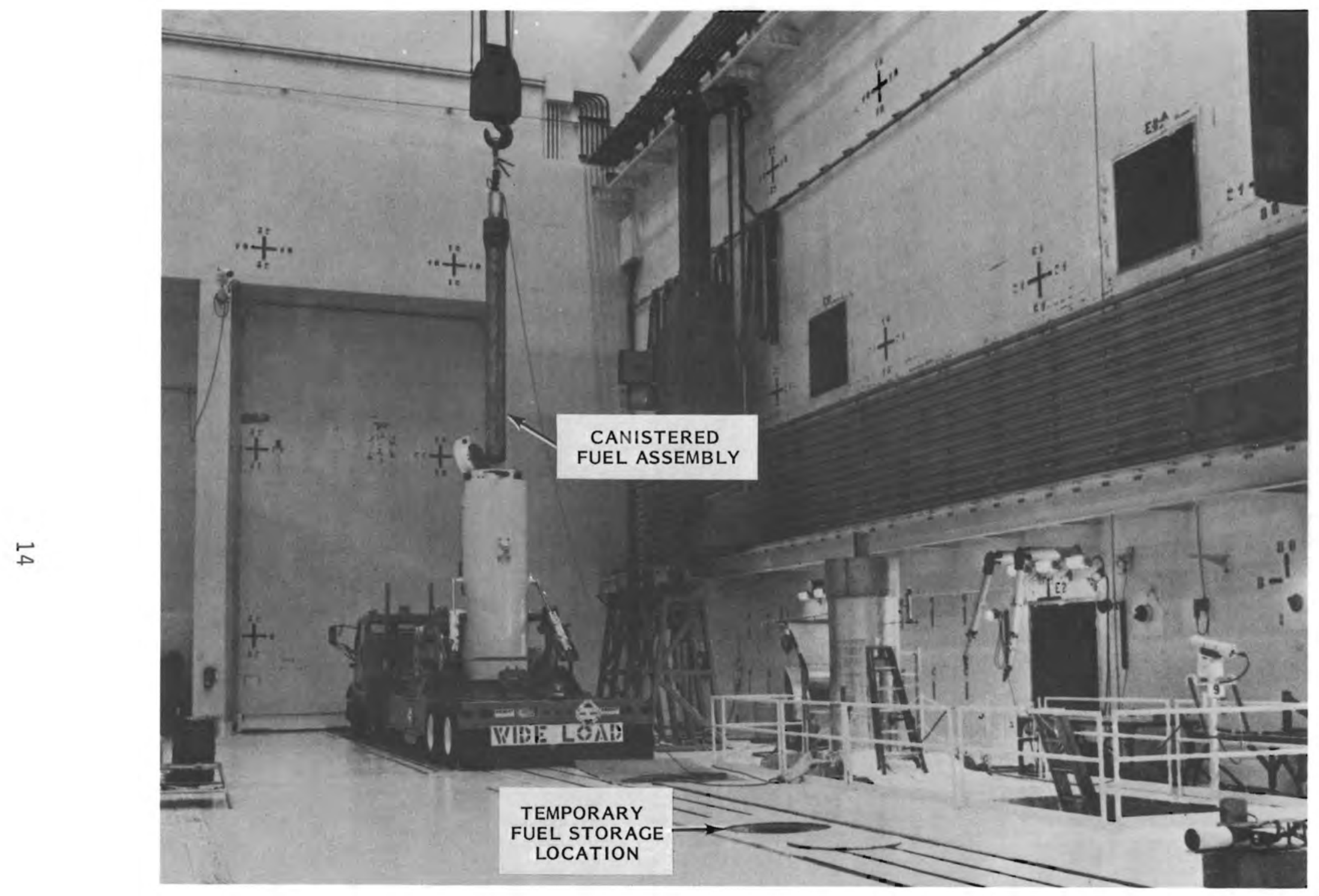

Neg. 82B905-1

FIGURE 6. Main Hot Cell for Remote Receipt and Handling of Irradiated Fuel Assemblies at E-MAD, Nevada Test Site. The view shows a canistered PWR assembly being placed into a shielded transporter. Vault storage area for LWR assemblies is out of view to the left. (Courtesy of DOE Nevada Operations.) 
FUEL RETRIEVAL FROM DRY STORAGE

Retrieving spent fuel from dry storage will generally be the reverse of the emplacement procedure. ${ }^{(6)}$ If the fuel is canned in an unfailed container, no radioactive species will be released to the storage facility, thus precluding a need for special radiation control measures for mobile radioactive species during retrieval. If the fuel is uncanned, the degree of mobile radioactivity released during dry storage should be assessed before retrieval proceeds. Crud released from fuel rod surfaces will likely comprise the principal mobile species. In the unlikely event that fuel cladding defects were to develop during storage, ${ }^{85} \mathrm{Kr}$, other fission products, and even fuel particles could be present in the storage facility or fuel container.

Fuel can be removed from the cask in the same pool or hot cell in which it was loaded; however, the loaded cask may be shipped to another pool for retrieval. If sampling indicates that the cask interior has substantial mobile contamination, special procedures may be required during fuel retrieval to localize the contamination. For example, the cask could be flushed to a radwaste system before it is opened in the pool if warranted by the contamination level.

INTERFACING INTERIM STORAGE WITH SUBSEQUENT FUEL OPERATIONS

It is appropriate to consider how interim storage procedures and designs may affect subsequent fuel management operations. Currently, the eventual options for spent fuel are reprocessing and/or geologic disposal of unreprocessed fuel. Reprocessing facilities can be designed to accept canistered fuel if the canister design and material are properly selected. Fuel shearing equipment is available to handle a SS canister of square cross section with 1/8-in. (3-mm) thick walls, even with consolidated fuel. Low alloy steel canisters would contaminate reprocessing solutions with iron, complicating the storage of waste processing solution. Stainless steel, however, has low corrosion rates in reprocessing solutions and thus does not add aggressive ions to the solution. While these considerations are important in some facilities, it is not certain that they will apply to all reprocessing facilities. Requirements for special spent fuel handling and/or packaging procedures must also consider possible impacts on reactor operations. 
The current base case for geologic disposal of unreprocessed spent fuel involves fuel consolidation to maximize space utilization. (28) If fuel is consolidated and placed in a canister prior to dry interim storage, the only additional step required for geologic disposal may be an overpack for the canister. If fuel enters dry interim storage unconsolidated, retrieval would probably be followed by removal from the canister (if canned), consolidation, and recanning for geologic disposal.

\section{DRY STORAGE CONCEPTS IN WASTE MANAGEMENT SCENARIOS}

Vault facilities in France currently store vitrified high-level wastes (HLW) in SS canisters. ${ }^{(29)}$ The technology is similar to interim vault storage of spent fuel. Vault storage concepts for fuel and HLW are also being evaluated in the Federal Republic of Germany ${ }^{(13)}$ and the United Kingdom. (30)

Dry storage concepts have been proposed for geologic disposal of spent fuel in several countries. $(1,31)$ The concepts involve fuel emplacement in repositories under dry conditions. In some respects, the geologic (..lcepts parallel dry interim storage. Projections of fuel behavior in geologic storage have been developed. (17)

Assessments of monitored retrievable storage (MRS) concepts for spent fuel and/or HLW are centered on dry storage technologies. Preliminary technology and cost assessments for MRS concepts have been published. $(32,33)$ 


\section{DRY STORAGE EXPERIENCE:}

STATE OF THE ART 


\section{DRY STORAGE EXPERIENCE: STATE OF THE ART}

This section begins with a discussion of the historical aspects of fuel handling under dry storage conditions. The current data bases for both nonZircaloy- and Zircaloy-clad fuels are reviewed. Facility information on fuel and cover gas temperatures, materials, corrosion, cover gases, radiation, and system monitoring is presented; and the integrity of dry storage facilities is discussed.

\section{HISTORICAL ASPECTS OF IRRADIATED FUEL HANDLING UNDER DRY CONDITIONS}

Irradiated nuclear fuel has been handled under dry conditions since the beginning of irradiated fuel examinations in hot cells in the mid-1940s, and irradiated water reactor fuel has been examined dry in hot cells since $\sim 1960$. Some irradiated water reactor fuel rods have been stored continuously at hot cells under dry conditions for approximately a decade, although at relatively low temperatures $\left(<100^{\circ} \mathrm{C}\right)$.

More recently, water reactor fuel assemblies have been shipped under dry conditions. Zircaloy-clad fuel has resided in dry casks during sea transport for 2 to 3 months at estimated temperatures from 150 to $450^{\circ} \mathrm{C}^{(29)}$--a range that will include most dry interim storage of irradiated fuel. Each cask holds 12 PWR assemblies, and each ship carries 10 to 20 casks. Several hundred assemblies have been shipped dry from Japan to Europe. The Zircaloy-clad fuel has not shown evidence of cladding failure due to handling and shipping, based on sampling of activity levels in cask atmospheres (inert and air) at the receiving site.

Although the vast majority of fuel shipments occur without substantial damage to the fuel cladding, ${ }^{(34)}$ one fuel shipping occurrence should be mentioned. A Connecticut Yankee fuel assembly with SS cladding was shipped from the reactor to the Battelle Columbus Laboratories (BCL) hot cell facility. (35) The assembly contained rods with known reactor-induced defects; the cask environment was air with some moisture. When the cask was opened in the reactor pool, considerable radioactive contamination was released to the pool and the pool enclosure. Oxidation of $\mathrm{UO}_{2}$ exposed at the cladding defects appears to have been a factor in the release. 
Handling irradiated fuel in hot cells has involved relatively short residences at elevated temperatures. Fuel assemblies may remain in air in hot cells for 1 to 2 weeks for rod removal and/or reinsertion. Individual rods from the Zorita reactor in Spain have been stored dry since 1978 after average burnups up to $62,000 \mathrm{MWd} / \mathrm{tU}$, based on information provided by Dr. A. Uriarte Hueda of the Junta de Energia Nuclear in Madrid.

DATA BASE FOR DRY STORAGE OF NON-ZIRCALOY-CLAD (GCR AND LMFBR) FUELS

The dry storage experience for GCR and LMFBR fuels is summarized in Table 1. Experience for these non-Zircaloy-clad fuels is potentially relevant to dry interim storage of other fuel types in the following areas:

- development of safety analyses for dry storage facilities

- demonstration of successful emplacement and retrieval of irradiated nuclear fuel in dry wells and vaults

- demonstration of safe operation of dry storage facilities over extended periods (dry wells and vaults since 1964)

- demonstration of low radiation levels and occupational exposures

- demonstration of inert cover gas monitoring and impurity control.

Appendix $B$ includes additional data regarding the scope of fuel storage for the dry storage facilities listed in Table 1.

A vault to store pebble-bed gas-cooled test reactor fuel has been completed at Julich (FRG). (36) Preparations are also under way to demonstrate storage of the pebble-bed reactor fuel at Jul'ch in a metal cask. (11) A dry storage vault (TOR) is under construction in France to store LMFBR fuel from the Phenix reactor. (29)

\section{DATA BASE FOR DRY STORAGE OF ZIRCALOY-CLF.D FUEL}

A data base is being developed for the dry interim storage of Zircaloyclad fuel. Demonstrations have been conducted on irradiated Zircaloy-clad fuel assemblies; electrically heated demonstrations have been performed to develop 
TABLE 1. Dry Storage of GCR and LMFBR Fuel(a)

\begin{tabular}{|c|c|c|c|c|c|c|c|}
\hline Site & $\begin{array}{l}\text { Storage } \\
\text { Facility } \\
\end{array}$ & $\begin{array}{l}\text { Type of } \\
\text { Storage }\end{array}$ & $\begin{array}{c}\text { Type } \\
\text { of Fuel } \\
\end{array}$ & $\begin{array}{c}\text { Fue } 1 \\
\text { Cladding } \\
\end{array}$ & $\begin{array}{c}\text { Earl iest } \\
\text { Fue } 1 \\
\text { Storage } \\
\end{array}$ & Cover Gas & Reference \\
\hline INEL & $\mathrm{HFEF} / \mathrm{S}(\mathrm{b})$ & Vault & LMFBR & SS & 1964 & Argon/air & 3 \\
\hline INEL & IFSF & Vault & HTGR & Graphite & 1975 & Air & 3 \\
\hline INEL & $\mathrm{HFEF} / \mathrm{N}$ & Vault & LMFBR & SS & 1975 & Argon & 3 \\
\hline Wylfa & Cells $1-3$ & Vault & Magnox & Mg alloy & 1971 & $\mathrm{CO}_{2}$ & $3,4,21$ \\
\hline Wylf a & Ce11 4,5 & Vault & Magnox & $\mathrm{Mg}$ alloy & 1979 & Air & $3,4,21$ \\
\hline INEL & ICPP & Dry well & HTGR & Graphite & 1971 & Helium & 3 \\
\hline INEL & ICPP & Dry we 11 & LMFBR & SS & 1974 & Helium & 3 \\
\hline I NEL & RSWF & Dry well & LMFBR & SS & 1964 & Air/argon & 3 \\
\hline
\end{tabular}

(a) See glossary for definition of terms used in the tables in this report.

(b) The HFEF/N and HFEF/S are principally used for examination of LMFBR fuel; irradiated fuel is stored for up to $1 \mathrm{yr}$. The HFEF/S has been out of service for refurbishment since 1978 .

temperature correlations; hot cell and laboratory studies using Zircaloy-clad rods or rod sections are under way; and some tests have been performed to verify the integrity of the Zircaloy cladding in dry storage.

Dry Storage Demonstrations: Irradiated Fuel Assemblies

Table 2 summarizes dry storage demonstrations of irradiated Zircaloy-clad fuel assemblies being stored in dry wells, vaults, silos, and casks. Actual storage facilities storing Zircaloy-clad fuel were previously shown in Figures $1,2,4$, and 5 . Appendix $B$ provides additional information on the demonstrations. The ongoing demonstrations provide the following insights to dry interim storage of Zircaloy-clad fuel:

- Fuel has been emplaced in casks, dry wells, vaults, and silos and retrieved from dry wells and vaults. Fuel retrieval from cask (KWW) and silo (E-MAD) demonstrations is planned.

- Startups of the demonstrations have been successful from safety and operational standpoints for all four concepts. 
TABLE 2. Dry Storage Demonstrations of Zircaloy-Clad Fuel

\begin{tabular}{|c|c|c|c|c|c|c|}
\hline $\begin{array}{l}\text { Storage } \\
\text { Facility }\end{array}$ & $\begin{array}{l}\text { Type of } \\
\text { Storage }\end{array}$ & $\begin{array}{c}\text { Type } \\
\text { of } \\
\text { Fuel } \\
\end{array}$ & $\begin{array}{l}\text { Earliest } \\
\text { Fuel } \\
\text { Storage } \\
\end{array}$ & $\begin{array}{l}\text { Number of } \\
\text { Assemblies } \\
\end{array}$ & $\begin{array}{c}\text { Total } \\
\text { Fuel Rods } \\
\text { in Test } \\
\end{array}$ & Reference \\
\hline E-MAD & $\begin{array}{l}\text { Surf ace } \\
\text { dry well }\end{array}$ & PWR & 1979 & 4 & 816 & 14,27 \\
\hline Climax & $\begin{array}{l}\text { Deep dry } \\
\text { well }\end{array}$ & PWR & 1980 & 11 & 2,244 & 14 \\
\hline E-MAD & Silo & PWR & 1978 & 1 & 204 & 14,27 \\
\hline$E-M A D$ & Vault & PWR & 1978 & $1(a)$ & 204 & 14,27 \\
\hline KWO & Test module & PWR & 1981 & 1 & 180 & 12,37 \\
\hline KWO & Test module & PWR & 1981 & 1 & 180 & 12,37 \\
\hline WNRE & Silo & $W R-1$ & 1975 & $138(b)$ & 2,484 & $3,8,25$ \\
\hline WNRE & Silo & PHWR & 1976 & $360(b)$ & 6,840 & $3,8,25$ \\
\hline KWW & Metal cask & BWR & 1982 & 16 & 896 & 2,37 \\
\hline
\end{tabular}

(a) Used for temporary storage of 17 PWR assemblies.

(b) PHWR and WR-1 assemblies are much smaller than LWR assemblies (see Appendix C, Tables C.1 and C.2).

- Canistered fuel is stored in dry well, vault, and silo facilities; retrieval from canisters has also been demonstrated. Uncanistered fuel is stored in a dry cask.

- Low radiation levels (typically 0.1 to $1 \mathrm{mrem} / \mathrm{h}$ ) in personnel access areas and low occupational doses during fuel handling and storage have been maintained.

Figure 7 illustrates time versus temperature data for selected Zircaloyclad assemblies in the dry storage demonstrations(a) ${ }^{(a m m a r i z e d}$ in Table 2, and Table 3 presents nominal temperature ranges for reactor residence, pool storage, and dry shipment and time in pool storage. (b) Hypothetical

(a) The arrows at the ends of the curves indicate tests that are continuing.

(b) Some Zircaloy-clad LWR fuel was shipped dry at estimated temperatures up to $450^{\circ} \mathrm{C} .(29)$ 


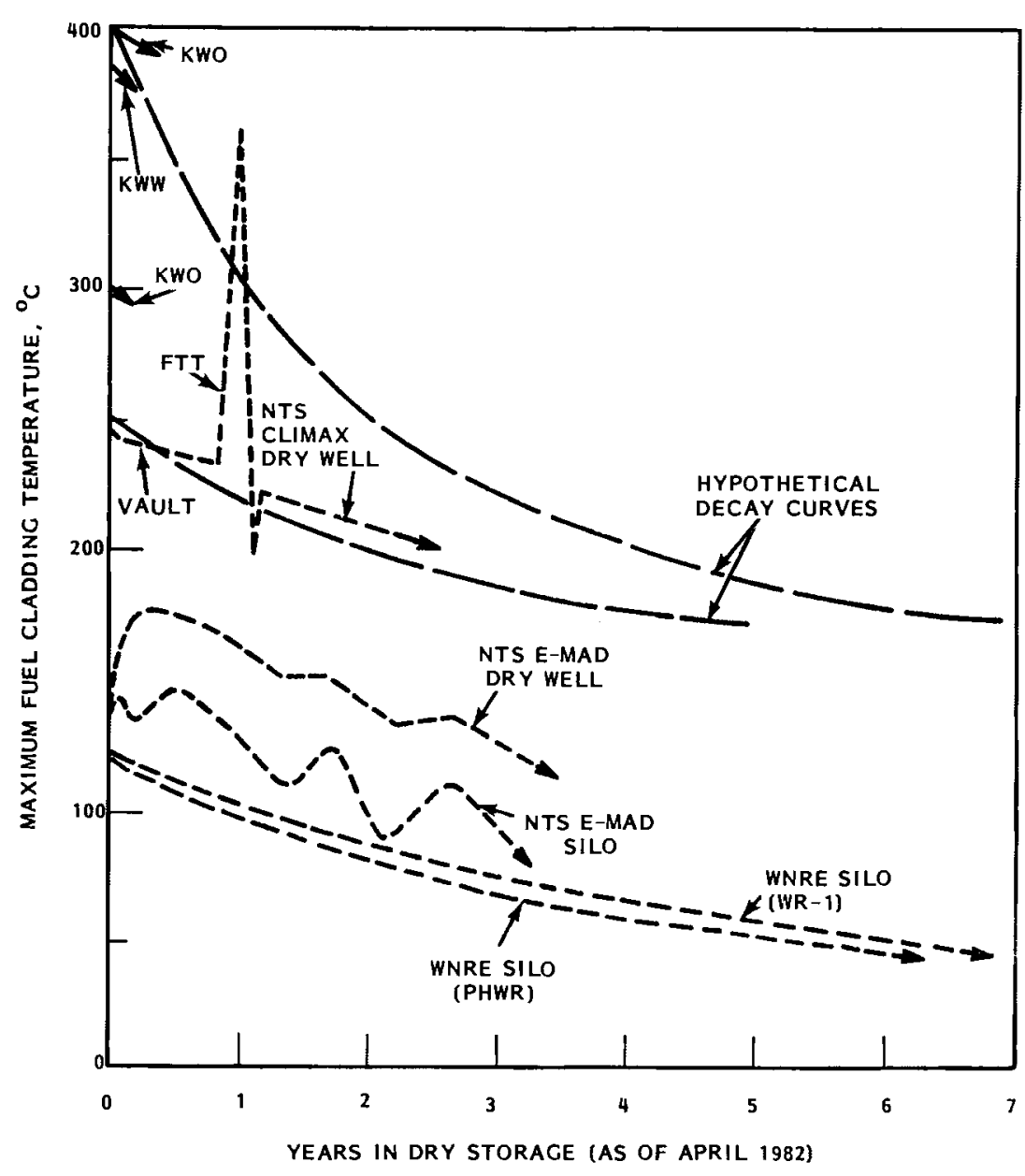

FIGURE 7. Zircaloy-Clad Fuel Assembly Temperature Histories for Dry Storage Demonstrations(16)

TABLE 3. Fue 1 Cladding Temperatures and Time in Pool Storage for Zircaloy-Clad Fuel in Dry Storage

\begin{tabular}{|c|c|c|c|c|c|}
\hline \multirow[b]{2}{*}{$\begin{array}{l}\text { Storage } \\
\text { Facility }\end{array}$} & \multirow{2}{*}{$\begin{array}{l}\text { Type } \\
\text { of } \\
\text { Fuel } \\
\end{array}$} & \multicolumn{3}{|c|}{ Fuel Cladding Temperature, ${ }^{\circ} \mathrm{C}$} & \multirow[b]{2}{*}{$\begin{array}{l}\text { Time in } \\
\text { Pool Storage } \\
\end{array}$} \\
\hline & & In-Reactor & $\begin{array}{l}\text { Storage } \\
\text { Pool } \\
\end{array}$ & $\begin{array}{c}\text { Dry } \\
\text { Shipping }\end{array}$ & \\
\hline KW0 & PWR & 300 to 375 & 20 to 60 & 150 to 300 & $4 \mathrm{mo}$ \\
\hline KWO & PWR & 300 to 375 & 20 to 60 & 150 to 300 & $10 \mathrm{mo}$ \\
\hline KWW & BWR & 275 to 350 & 20 to 60 & 150 to 300 & $13 \mathrm{mo}$ \\
\hline NTS & PWR & 300 to 375 & 20 to 60 & 150 to 300 & 2 to $3 \mathrm{yr}$ \\
\hline WNRE & PHWR & 275 to 350 & 20 to 60 & 150 to 300 & 0.5 to $4 \mathrm{yr}$ \\
\hline
\end{tabular}


temperature decay curves are also indicated in Figure 7 for PWR assemblies residing in a cask at maximum initial temperatures of 250 and $400^{\circ} \mathrm{C}$. These decay curves are based on calculated thermal characteristics for a dry multielement cask and must be regarded as preliminary until actual cask temperature monitoring data are available. Cladding temperatures for the NTS tests shown in Figure 7 are for specific assemblies. There are 4 assemblies in surface dry wells, 11 assemblies in deep dry wells, 1 assembly in a silo, and 1 assembly in a vault. The spike on the temperature curve for the $\mathrm{Cl}$ imax assembly was generated during a temperature calibration test in the fuel temperature test (FTT) stand at E-MAD ${ }^{(38)}$ before the assembly was emplaced in the Climax dry well.

Demonstrations involving PWR assemblies were instrumented with thermocouples inside the hollow guide tubes, which are interspersed among the Zircaloy fuel rods. For example, in dry storage tests conducted at the Kernkraftwerk Obrigheim (KWO) PWR, seven thermocouples were spaced along the length of one guide tube and three thermocouples were placed in each of two other guide tubes. $(12,37)$ It is estimated that the fuel cladding operates only a few degrees hotter than the guide tube temperatures.

The fuel cladding temperatures of assemblies in the E-MAD demonstrations are obtained in two steps: $(38)$

- Correlations between cladding temperature and canister temperature were developed during two tests on irradiated Turkey Point PWR assemblies in the electrically neated FTT apparatus. One assembly was heated in steps to $300^{\circ} \mathrm{C}$; the other assembly was heated in steps to $360^{\circ} \mathrm{C}$.

- The correlations developed in the FTT series provided a basis for estimating cladding temperatures of assemblies in dry well and silo tests based on the wall temperature, of the metal canisters containing the irradiated assemblies.

The following observations can be drawn from Figure 7 and Table 3: 
- Collectively, the demonstration tests cover starting temperatures from 120 to $400^{\circ} \mathrm{C}$. FRG tests extend temperatures to the upper range $\left(300\right.$ and $\left.400^{\circ} \mathrm{C}\right)$; $^{(\mathrm{a})}$ NTS tests cover the intermediate range (100 to $250^{\circ} \mathrm{C}$ with brief increases to 300 and $360^{\circ} \mathrm{C}$ on two assemblies); and WRNE tests cover the lower temperature range $\left(120^{\circ} \mathrm{C}\right.$, decreasing to $\sim 40^{\circ} \mathrm{C}$ ).

- Several types of fuel with zirconium alloy fuel cladding are represented: BWR at KWW; pressurized heavy-water reactor (PHWR) at WNRE; PWR at KWO and NTS; and PHWR and WR-1 at WNRE. The cladding on the WR-1 fuel is $\mathrm{Zr}-2.5 \mathrm{Nb}$; the other fuel in the demonstrations is clad with Zircaloy-2 (BWR) or Zircaloy-4 (PHWR and PWR). See Appendix C for cladding compositions.

- Comparisons of reactor cladding temperature ranges indicate that the KWO and KWW maximum cladding temperatures approach the reactor operating temperature range for the fuel cladding; NTS and WNRE tests were conducted below the reactor operating range except for brief temperature calibration tests on one NTS assembly up to $\sim 360^{\circ} \mathrm{C} .{ }^{\text {(38) }}$

- The assemblies had cooling times varying from 4 months and 10 months for KWO assemblies, to 13 months for KWW assemblies, to 2 to $3 \mathrm{yr}$ for NTS assemblies, to 0.5 to $4 \mathrm{yr}$ for WNRE assemblies.

- Fuel handling histories vary for the various demonstrations. The KWW and KWO demonstrations were conducted at the reactors where the fuel was discharged; the NTS assemblies were discharged at the Turkey Point PWR. Some Turkey Point assemblies were shipped dry to BCL for characterization and then to NTS for storage; some were shipped dry directly to NTS from the reactor. Shipping of the WR-1 fuel was not necessary because the reactor is at the dry storage site (WNRE); the PHWR fuel was discharged from the Douglas Point reactor and shipped

(a) A few center rods in the $\mathrm{KWW}$ cask test were near $385^{\circ} \mathrm{C}$; estimated temperatures on other rods were as low as $180^{\circ} \mathrm{C}$ at the beginning of the test. 
to WNRE. Temperatures during dry shipments are not known precisely but probably generally fall within the range of 150 to $300^{\circ} \mathrm{C}$, (a) depending on the assembly heat rating. Temperatures for Turkey Point assemblies stored dry in a hot cell were less than $100^{\circ} \mathrm{C}$, based on $\mathrm{BCL}$ observations (burnup was $\sim 27,000 \mathrm{MWd} / \mathrm{tU}$; the assemblies were out of the reactor for $\sim 3 \mathrm{yr}$ ).

- Zircaloy-clad fuel has been stored dry for nearly 7 yr but at relatively low temperatures (from $120^{\circ} \mathrm{C}$ down to $\sim 40^{\circ} \mathrm{C}$ ).

Above $400^{\circ} \mathrm{C}$, radiation damage in Zircaloy cladding tends to anneal quite rapidly; therefore, cladding mechanical properties will change relative to asirradiated properties. Ductilities will increase and strengths will decrease. Cladjing in demonstrations at relatively low temperatures will probably maintain properties close to as-irradiated properties for the duration of the dry storage. If annealing occurs, it is not expected to cause problems in dry storage; in fact, it tends to improve cladding ductility. The principal consideration is to select test conditions that address cladding prope, ies of prime interest in dry storage.

Dry Storage Demonstrations: Electrically Heated Assemblies

At Hanford a carbon steel (CS)-lined electrically heated dry well was tested for approximately 1 yr (1978) to develop temperature correlations. (3) A 1-kW heater was mounted inside a steel canister; the canister was operated at 210 to $218^{\circ} \mathrm{C}$; and the maximum cladding temperature was estimated to be $277^{\circ} \mathrm{C}$. Although corrosion assessment was not a major consideration in the test, the CS liner had developed only minor corrosion without cathodic protection after $2 \mathrm{yr}$ in contact with the relatively dry Hanford soil.

At E-MAD a CS liner was buried in the relatively dry NTS soil and coated with a concrete/soil grout. (3) A SS canister containing an electric heater was heated for extended times with 1-, 2-, and 3-kw inputs. At $1 \mathrm{~kW}$, the peak $\mathrm{C}$ anister temperature was $135^{\circ} \mathrm{C}$; at $2 \mathrm{~kW}, 266^{\circ} \mathrm{C}$; and at $3 \mathrm{~kW}, 418^{\circ} \mathrm{C}$. The tests were conducted between 1978 and 1980 .

(a) Estimated cladding temperatures in dry shipping casks range up to $\sim 450^{\circ} \mathrm{C}$. (29) 
During 1974-75, 2-kW and 5-kW electrically heated silo tests were conducted at WNRE; ${ }^{(3)}$ and during 1976-77, similar tests were conducted at $2 \mathrm{~kW}$ and $11 \mathrm{~kW} .{ }^{(3)}$ Measured temperature gradients were about $50 \%$ lower than anticipated due to higher-than-expected concrete thermal conductivity. The tests were conducted at heat loads up to 2.5 times the design level. Heating at the highest rates induced some cracking in the concrete, but the cracks did not impair the function of the concrete. From these tests, it is estimated that heat loads to at least $11 \mathrm{~kW}$ can be tolerated by the silo design. Hot Cell and Laboratory Studies: Zircaloy-Clad Fuel Rods

In addition to demonstrations that are under way on full Zircaloy-clad assemblies, other studies (see Table 4) are planned or under way using irradiated Zircaloy-clad rods or rod sections and unirradiated materials. These studies will define specific phenomena related to cladding and fuel pellet behavior in dry storage. The following phenomena are being investigated:

- prospects for cladding rupture during dry storage

- behavior of through-wall and incipient cladding defects under dry storage conditions

- prospects for stress corrosion cracking (SCC) in dry storage regimes

- oxidation rates of fuel pellets exposed to an oxidizing cover gas at cladding defects

- cladding reactions with cover gases

- behavior of crud in various dry storage environments.

The hot cell and laboratory studies are directed to definition of specific phenomena. The demonstrations involve larger numbers of fuel rods and provide better statistics. The two approaches are complementary in the development of a dry storage data base.

German laboratory tests are addressing the following aspects of Zircaloy behavior: $(12,37)$ 
TABLE 4. Hot Cell and Laboratory Dry Storage Studies(a)

\begin{tabular}{|c|c|c|}
\hline Country & Organization & Type of Fuel \\
\hline Canada & $\begin{array}{l}\text { WNRE } \\
\text { Ontario Hydro }\end{array}$ & $\begin{array}{l}\text { PHWR (b) } \\
\text { PHWR }\end{array}$ \\
\hline FRG & $\begin{array}{l}\text { DWK, KWU } \\
\text { German Ministry of Res. \& Tech: } \\
\text { DWK, JRC, KWO, KWU, PE, and TN }\end{array}$ & $\begin{array}{l}\text { PWR } \\
\text { BWR, } \operatorname{PWR}(\mathrm{c})\end{array}$ \\
\hline USA & $\begin{array}{l}\text { DOE } \\
\text { NRC } \\
\text { TVA/EPRI }\end{array}$ & $\begin{array}{l}B W R, P W R(d) \\
B W R, P W R \\
P W R \text { and un irradiated }\end{array}$ \\
\hline
\end{tabular}

(a) Scopes of some of the studies are still being defined.

(b) Tests are under way and will be evaluated in 1983.(25)

(c) As of April 1982, 9 months of testing has been completed $(9,12,37)$

(d) Six months of testing at 480 to $570^{\circ} \mathrm{C}$ has been completed.(17)

- Iodine SCC tests in Zircaloy capsules at 100 and $300^{\circ} \mathrm{C}$; pressures of 62 and $95 \mathrm{MPa} ; 0$ to $1 \times 10^{-5} \mathrm{~g} / \mathrm{cm}^{2}$ of iodine.

- Postirradiation creep on 10 PWR cladding samples; preirradiated; hoop stress (tensile/compressive) of 100 and $120 \mathrm{MPa}$; durations of 550 and $1170 \mathrm{~h}$; test temperature of $400^{\circ} \mathrm{C}$; hoop stresses of $70 \mathrm{MPa}(=45$ bars at room temperature); profilometry after $0 / 1000 / 2000 / 4000 / 8000 \mathrm{~h}$. Canadian fuel integrity tests ${ }^{(a)}$ include exposure of irradiated fuel assemblies with defective and intact fuel rods to moist and dry air at $150^{\circ} \mathrm{C} .{ }^{(8,25)}$ Several U.S. testing programs (see Table 4) are being developed to investigate fuel oxidation, SCC of Zircaloy cladding induced by fission products, stress rupture, cladding defect behavior, crud behavior, and hydrogen effects.

\section{Verification of Zircaloy $\mathrm{Cl}$ adding Integrity in Dry Storage}

Methods to define Zircaloy cladding integrity in dry storage include:

- visuar inspections

- sampling dry storage cover gases for ${ }^{85} \mathrm{Kr}$

(a) A Canadian safeguards system for verifying fuel in dry storage has been developed. (8) 
- nondestructive tests (eddy current, profilometry, ultrasonics, gamma scans)

- metallurgical examinations

- laboratory studies to define Zircaloy behavior in dry storage

- assessments from known Zircaloy behavior.

Demonstrations and Whole Rod Tests

Several tests have been conducted to verify the integrity of Zircaloy cladding in dry storage. To date none of the integrity tests has indicated that the cladding is degrading. In addition to the whole rod tests and followon testing indicated in Table 5, other Zircaloy cladding integrity studies are planned:

- Fuel from a Canadian fuel damage test (CEX) will be examined beginning in 1983 after $3 \mathrm{yr}$ in the test. (8)

- BWR fuel in a cask test at the KWW reactor (FRG) will be examined at the end of a 2-yr test that began early in 1982. (9)

- Gas analyses, visual inspections, and hot cell examinations will be perf ormed on fuel in NTS dry storage demonstrations.

- Fuel rods in DOE and U.S. Nuc lear Regulatory Commission (NRC) tests will be examined periodically, some over a 5-yr period.

- Where practical, fuel integrity considerations will be factored into future U.S. dry storage tests.

\section{Dry Storage Integrity Assessments}

Assessments of expected Zircaloy clad fuel behavior in dry storage have been conducted. In a U.S. study, ${ }^{(39)}$ potential cladding failure mechanisms were assessed, drawing from the large body of data regarding the behavior of Zircaloy-clad fuel. The study concluded that dry storage of Zircaloy-clad fuel at starting temperatures to $\sim 385^{\circ} \mathrm{C}$ is not expected to cause cladding failure over very long time spans $(\sim 1000 \mathrm{yr})$. Testing at 480 to $570^{\circ} \mathrm{C}$ in helium and 1 imited air did not produce cladding ruptures, but radiation damage was 
TABLE 5. Cladding Integrity Verification for Zircaloy-Clad Fuel in Dry Storage Tests

\begin{tabular}{|c|c|c|c|c|c|c|c|c|c|c|}
\hline Site & $\begin{array}{c}\text { Type } \\
\text { of } \\
\text { Fuel } \\
\end{array}$ & & $\begin{array}{l}\text { Number } \\
\text { Tested }\end{array}$ & $\begin{array}{l}\text { Average } \\
\text { Burnup, } \\
\text { Mwd/tU }\end{array}$ & Cover Gas & 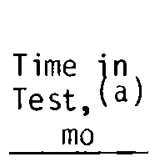 & $\begin{array}{l}\text { Starting } \\
\text { Dry Storage } \\
\text { Temperature, } \\
{ }^{\circ} \mathrm{C} \\
\end{array}$ & Type of Verification & Future Plans & Reference \\
\hline$\overline{\text { NTS }}$ & PWR & 4 & assemblies & 27,000 & Helium & $\leq 5$ & $\sim 230$ & $85 \mathrm{kr}$ analysis & $\begin{array}{l}\text { Further } \mathrm{Kr} \text { analysis; } \\
\text { visual inspection; } \\
\text { hot cell examination }\end{array}$ & 18 \\
\hline NTS & PWR & 2 & assemblies & 27,000 & Helium & 18 & $\sim 180$ & $85 \mathrm{Kr}$ analysis & $\begin{array}{l}\text { Further } \mathrm{Kr} \text { analysis; } \\
\text { visual inspection; } \\
\text { hot cell examination }\end{array}$ & 18 \\
\hline $\mathrm{BCL}$ & PWR & & rods & 27,000 & $\begin{array}{l}\text { Helium/ } \\
\text { air }\end{array}$ & 6 & 480 to 570 & $\begin{array}{l}85 \mathrm{Kr} \text { analysis; NOT } \\
\text { and hot cell } \\
\text { examination }\end{array}$ & $\begin{array}{l}\text { Further rod tests } \\
\text { at } 325^{\circ} \mathrm{C}\end{array}$ & 17 \\
\hline Ispra & PWR & 9 & $\operatorname{rods}(b)$ & 33,000 & Helium & 10 & $\leq 400$ & $\begin{array}{l}85 \mathrm{kr} \text { analysis; } \\
\text { visual inspection; } \\
\text { NDT }\end{array}$ & $\begin{array}{l}\text { Further examinations } \\
\text { after } 400^{\circ} \mathrm{C} \text { testing }\end{array}$ & 9,12 \\
\hline Ispra & BWR & 14 & $\operatorname{rods}(b)$ & 24,000 & Helium & 10 & $\leq 400$ & $\begin{array}{l}85 \mathrm{kr} \text { analysis; } \\
\text { vi sual inspection; } \\
\text { NDT }\end{array}$ & $\begin{array}{l}\text { Further examinations } \\
\text { after } 400^{\circ} \mathrm{C} \text { testing }\end{array}$ & 9,12 \\
\hline KWO & PWR & 1 & assemb ly & $\begin{array}{l}\text { up to } \\
-42,000\end{array}$ & Moist $\mathrm{N}_{2}$ & 2 & 300 & $\begin{array}{l}85_{\mathrm{Kr}} \text { analysis; } \\
\text { post-test sipping }\end{array}$ & & 12,37 \\
\hline KWO & PWR & 1 & a ssembly & 33,000 & Moist $\mathrm{N}_{2}$ & 4 & 400 & Several $85 k r$ analyses & Further testing & 12,37 \\
\hline
\end{tabular}

(a) Time when integrity test was conducted; see Appendix B for demonstration test histories.

(b) Archive rod was also available for examination. 
annealed in the tests. (17) Additional tests are being conducted at lower temperatures to investigate cladding behavior with residual radiation effects in the cladding.

German investigators have conducted assessments of Zircaloy cladding behavior and also conclude that dry storage conditions do not appear to present technical difficulties. $(12,37)$

\section{CHARACTERISTICS OF EXISTING DRY STORAGE FACILITIES}

Information on the following facility characteristics was collected from the published literature and from discussions with pertinent facility personnel. Fuel and cover gas temperatures, materials, corrosion considerations, cover gases, radiation readings, and methods to monitor system integrity are discussed.

Fuel and Cover Gas Temperatures

Fuel and cover gas temperatures recorded at INEL, NTS, Wylf and WNRE dry storage facilities are presented in Table 6 . In several facilities (identified in the table by $N A$ ), no direct temperature monitoring was deemed necessary. Materials

The major materials used in dry storage facilities are described in Table 7. Some of the facilities have operated since 1964-66; therefore, there is a basis to evaluate storage facility and component performance over substantial time spans. At these facilities, metals (mainly CS and SS) have been in contact with air, soil, and concrete. Materials and equipment have been subject to radiation fields over extended times. In general, materials and equipment performance appears to have been free of serious problems; some operational problems have been discussed. (3) While few specific materials evaluations have been reported, the basis exists to perform evaluations in cases where design of future facilities would benefit. In cases where specific evaluations have been conducted, the materials met or exceeded design expectations. At E-MAD, the service life of dry wells is expected to exceed $100 \mathrm{yr},{ }^{(3)}$ based 
TABLE 6. Fuel and Cover Gas Temperatures at Dry Storage Facilities

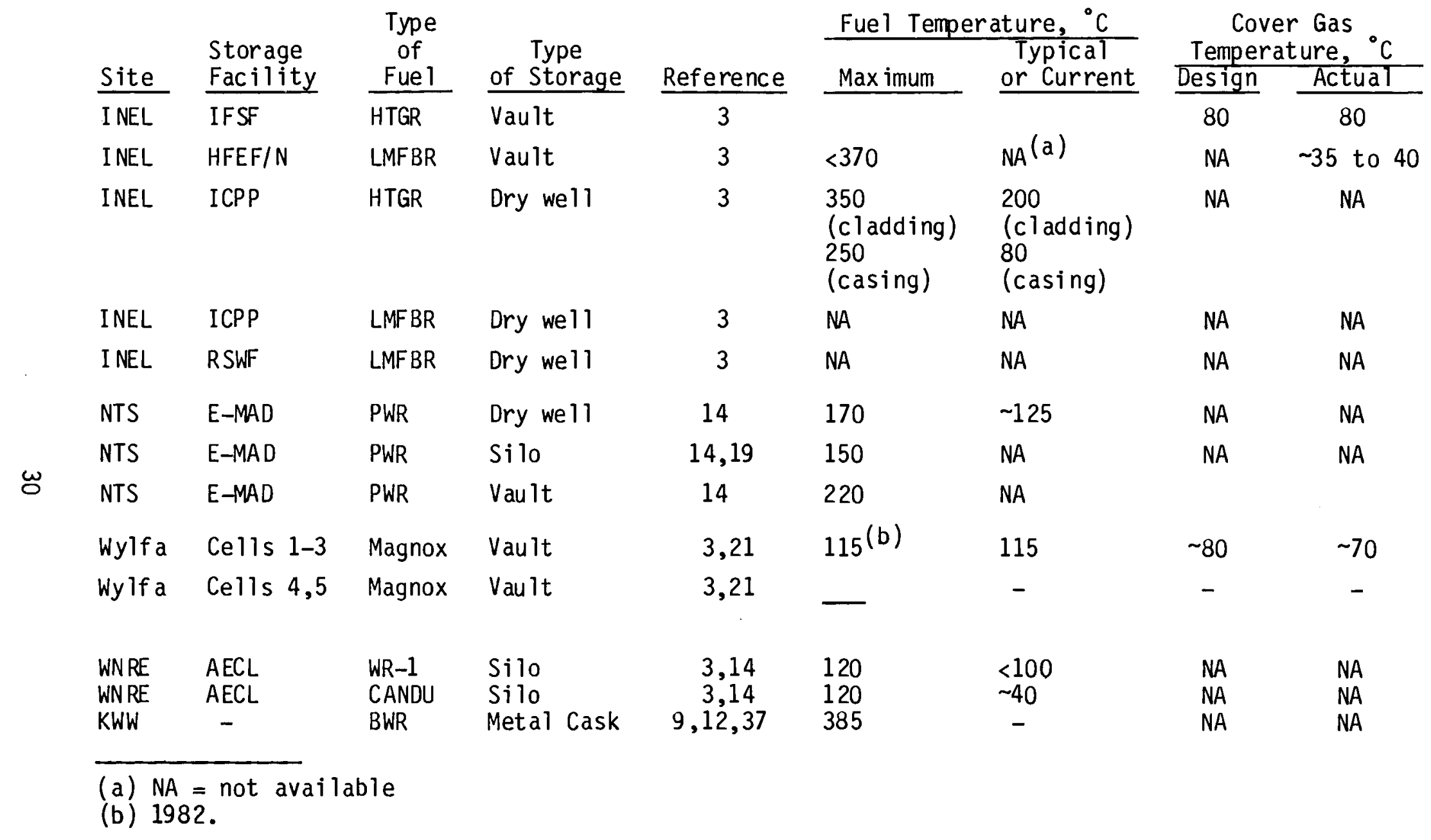




\section{TABLE 7. Dry Storage Facility Materials}

\begin{tabular}{|c|c|c|c|c|c|c|c|c|c|c|c|c|}
\hline & \multirow[b]{2}{*}{ Site } & \multirow[b]{2}{*}{$\begin{array}{r}\text { Storage } \\
\text { Facility } \\
\end{array}$} & \multirow[b]{2}{*}{$\begin{array}{c}\text { Date of } \\
\text { First } \\
\text { Operation }\end{array}$} & \multirow[b]{2}{*}{$\begin{array}{c}\text { Type } \\
\text { of } \\
\text { Fuel } \\
\end{array}$} & \multirow[b]{2}{*}{$\begin{array}{c}\text { Fuel } \\
\text { Cladding }\end{array}$} & \multirow[b]{2}{*}{$\begin{array}{l}\text { Type of } \\
\text { Storage }\end{array}$} & \multirow[b]{2}{*}{ Reference } & \multicolumn{5}{|c|}{ Major Materials } \\
\hline & & & & & & & & $\begin{array}{c}\text { Outer } \\
\text { Conta inment } \\
\end{array}$ & Liner & Canister & $\begin{array}{l}\text { Storage } \\
\text { Racks } \\
\text { Baskets } \\
\end{array}$ & Other \\
\hline & INEL & IFSF & 1975 & $H T G R$ & Graphite & Vault & 3 & $\begin{array}{l}\text { Reinforced } \\
\text { concrete }\end{array}$ & SS & CS & CS & $\begin{array}{l}\text { Glass windows; Al } \\
\text { shipping cans }\end{array}$ \\
\hline & I NEL & $\mathrm{HFEF} / \mathrm{N}(\mathrm{a})$ & 1975 & LMFBR & ss & Vault & 3 & $\begin{array}{l}\text { Reinf orced } \\
\text { concrete }\end{array}$ & $\begin{array}{l}\text { Galvanized } \\
\text { steel }\end{array}$ & $\begin{array}{l}\text { Galvanized } \\
\text { steel or } \\
\text { SS }\end{array}$ & $N A(b)$ & Some Al tubes \\
\hline & Wy If a & Cells 1-3 & 1971 & Magnox & $\begin{array}{l}\mathrm{Mg}-\mathrm{Al} \\
\text { alloy }\end{array}$ & Vault & 3,21 & $\begin{array}{l}\text { Reinforced } \\
\text { concrete }\end{array}$ & No finish & & CS & \\
\hline & Wylf a & Cells 4,5 & 1979 & Magnox & $\begin{array}{l}\text { Mg-Al } \\
\text { alloy }\end{array}$ & Vault & 3,21 & $\begin{array}{l}\text { Reinforced } \\
\text { concrete }\end{array}$ & $\begin{array}{l}\text { Painted } \\
\text { on inside }\end{array}$ & & CS-AI spray & \\
\hline & NTS & $E-M A D$ & 1979 & PWR & Zircaloy & Vault & 14 & Concrete & & SS & NA & \\
\hline & INEL & ICPP & 1971 & HTGR & Graphite & $\begin{array}{l}\text { Dry } \\
\text { well }\end{array}$ & 3 & Soil & $\begin{array}{l}\text { is tube } \\
\text { mild steel }\end{array}$ & $\begin{array}{l}6061 \text { A) } \\
\text { (outer); } \\
\text { (inner) }\end{array}$ & WA & Concrete end plugs \\
\hline & INEL & ICPP & 1974 & LMFBR & SS & $\begin{array}{l}\text { Dry } \\
\text { we11 }\end{array}$ & 3 & Soil & CS tube & $\begin{array}{l}\text { SS } \\
\text { (outer); } \\
\text { mild steel } \\
\text { (inner) }\end{array}$ & NA & Concrete end pluys \\
\hline \multirow[t]{6}{*}{$\stackrel{\omega}{\omega}$} & NTS & E-MAD & 1979 & PWR & Zircaloy & $\begin{array}{l}\text { Dry } \\
\text { well }\end{array}$ & 14 & $\begin{array}{l}\text { Concrete } \\
\text { grout }\end{array}$ & CS tube & ss & INA & $\begin{array}{l}\text { Shield plug (CS } \\
\text { filled with } \\
\text { concrete) }\end{array}$ \\
\hline & INEL L & RSWF & 1964 & LMFBR & sS & $\begin{array}{l}\text { Dry } \\
\text { well }\end{array}$ & 3 & Soil & CS tube & $\begin{array}{l}\text { SS } \\
\text { (outer): } \\
\text { CS or SS } \\
\text { (inner) }\end{array}$ & WA & $\begin{array}{l}\text { Shield plug } \\
\text { (concrete or lead) }\end{array}$ \\
\hline & NTS & E-MAD & 1978 & PWR & Zircaloy & Silo & 14,19 & $\begin{array}{l}\text { Reinforced } \\
\text { concrete }\end{array}$ & Mild steel & & NA & $\begin{array}{l}\text { Steel bottom and } \\
\text { top plates; shield } \\
\text { plug (CS filled } \\
\text { with concrete) }\end{array}$ \\
\hline & WNRE & AECL & 1975 & WR-1 & Zircaloy & Silo & 3,25 & $\begin{array}{l}\text { Reinforced } \\
\text { concrete }\end{array}$ & CS & $\mathrm{CS}$ & CS & $\begin{array}{l}\text { Lead shielding; } \\
\text { steel or ceramic } \\
\text { fillers for } \\
\text { baskets }\end{array}$ \\
\hline & WNRE & AECL & 1976 & CANDU & Zircaloy & Silo & 3,25 & $\begin{array}{l}\text { Reinforced } \\
\text { concrete }\end{array}$ & CS & CD & CS & $\begin{array}{l}\text { Lead shielding; } \\
\text { steel or ceramic } \\
\text { fillers for } \\
\text { baskets }\end{array}$ \\
\hline & KWW & - & 1982 & BWR & Zircaloy & $\begin{array}{l}\text { Metal } \\
\text { cask }\end{array}$ & $9,12,37$ & $\begin{array}{l}\text { Nodular } \\
\text { cast Fe }\end{array}$ & $\begin{array}{l}\text { Nickel } \\
\text { plate }\end{array}$ & None & $\begin{array}{l}\text { Boronated } \\
\text { SS }\end{array}$ & \\
\hline
\end{tabular}

(a) A nearby facility (HFEF/S) began operation in 1964 with air and argon used for cover gases; the argon cell of HFEF/S has been out of service since 1978 (b) $\mathrm{NA}=$ ref urbi shment. 
on a conservative design. At INEL, dry wells are expected to survive for at least $25 \mathrm{yr}$ in contact with soils without cathodic protection. (3)

Corrosion Considerations

Some sites have taken specific measures to assess corrosion (see Table 8 ). For example, at the ANL -West site at INEL, 37 CS dry well 1 iners were removed and inspected after 8 to $10 \mathrm{yr}$ in contact with soil. (3) Visual inspection indicated that they were in good condition. One tube was examined by metallurgical techniques after $7 \mathrm{yr}$ of exposure, and the corrosion layer was only $0.1 \mathrm{~mm}$ thick. Another tube was examined after $14 \mathrm{yr}$ of service and provided a basis to predict at least 10 more years of useful tube 1 ife. Cathodic protection is provided to suppress corrosion of some tubes at the site but not for the tubes that were inspected. The INEL site is relatively dry and the soil is sandy and well drained; sites in humid locations or with different soil types would need to make preassessments to ensure adequate materials performance.

There is no evidence that serious fuel cladding degradation has occurred at the dry storage site, based on monitoring for radioisotopes; how er, few cases have been reported where fuel was retrieved from storage locations for detailed inspection. (3) The relatively mild storage conditions for GCR and LMFBR fuels are not expected to degrade the cladding seriously; however, moist air is aggressive to sensitized stainless steel. ${ }^{(40)}$ This observation must be evaluated when selecting storage conditions for GCR and LMFBR fuel with SS cladding because reactor operating conditions are in the range where sensitization of susceptible materials can occur.

Cover Gases

Experience at various dry storage sites has involved the following cover gases: air, argon, carbon dioxide, and helium (see Table 9). Nitrogen is considered to be a satisfactory replacement for argon at HFEF, but it has not been substituted. Where cover gas selection is a major consideration for future facilities, experience at operating sites may be valuable to assess interactions with materials, heat transfer characteristics, gas monitoring, and purity control. 
TABLE 8. Corrosion Considerations for Dry Storage

\begin{tabular}{|c|c|c|c|c|}
\hline Site & $\begin{array}{l}\text { Storage } \\
\text { Facility }\end{array}$ & $\begin{array}{l}\text { Type of } \\
\text { Storage }\end{array}$ & References & Corrosion Aspects \\
\hline INEL & IFSF & Vault & 3 & $\begin{array}{l}\text { Dry climate; corrosion not a problem; vital } \\
\text { components remotely replaceable or made of } \\
\text { corrosion-resistant materials. }\end{array}$ \\
\hline INEL & HFEF/N & Vault & 3 & $\begin{array}{l}\text { LMFBR fuel cladding tends to become sen- } \\
\text { sitized and may be susceptible to IGSCC in } \\
\text { moist environments. }\end{array}$ \\
\hline Wylfa & Cel1s 1-5 & Vault & 3,21 & $\begin{array}{l}\text { Fresh fuel stored in } \mathrm{CO}_{2} \text { (cells } 1-3 \text { ); older } \\
\text { fuel stored in air (cells } 4,5) ; \text { facility } \\
\sim 100 \mathrm{~m} \text { from seacoast. }\end{array}$ \\
\hline
\end{tabular}

$\begin{array}{lllll}\omega & \text { INEL } & \text { ICPP } & \text { Dry well } & 3 \\ & \text { INEL } & \text { RSWF } & \text { Dry well } & 3\end{array}$

Soil--sand and gravel; relatively dry; decay heat reduces moisture on tube walls.

Steel tube excludes moisture from fuel canister. After 8-10 yr, 37 dry well 1 iners and exterior surfaces in good condition; nondestructive examination after $7 \mathrm{yr}$ showed $0.1-m m$ corrosion layer and no structural damage; after $14 \mathrm{yr}$, corrosion still minimal $25-y r$ life in contact with soil is expected.

\begin{tabular}{|c|c|c|c|c|}
\hline NTS & $E-M A D$ & Dry well & 14 & $\begin{array}{l}\text { No steel-soil contact; } 100-y r \text { service life } \\
\text { is estimated; relatively dry conditions. }\end{array}$ \\
\hline NTS & $E-M A D$ & Silo & 14,19 & $\begin{array}{l}\text { Dry climate; located above ground in air; } \\
\text { fuel assembly protected by concrete cask, } \\
\text { CS liner, and sealed SS canistar. }\end{array}$ \\
\hline WRNE & $\mathrm{AECl}$ & Silo & 3,25 & $\begin{array}{l}\text { Concrete "corrosion" not expected to be } \\
\text { serious in } 100 \text { yr; but temperature can cause } \\
\text { concrete to crack. At }<400^{\circ} \mathrm{C} \text {, both } \mathrm{O}_{2} \text { and } \\
\mathrm{H}_{2} \mathrm{O} \text { are required to oxidize } \mathrm{CS} \text {. }\end{array}$ \\
\hline
\end{tabular}

KWW - $\quad \begin{aligned} & \text { Metal 9,12,37 Cask temperature above dew point, which } \\ & \text { cask }\end{aligned}$

cask minimizes atmospheric corrosion.

\author{
Corrosion Control \\ Fuel temperature maintained below oxidation \\ range $\left(<250^{\circ} \mathrm{C}\right)$. \\ $\mathrm{Na}$ removed from fuel rod surfaces; maintain \\ low cover gas temperatures; maintain inert \\ cover gas where required. LMFBR assemblies \\ are packaged in SS (air cover gas) prior to \\ wet storage.
}

Fuel corrosion minimized by absence of $\mathrm{H}_{2} \mathrm{O}$ and low heat output before air exposure; $U$ ignition precluded by low temperature; humidity control ( $<50 \%)$; Al coating used on CS to protect from sea spray.

Cathodic protection of steel tubes; dry well designed to exclude moisture.

Cathodic protection provided for large. (0.9-m dia) steel tubes; smaller tubes (0.5-m dia) not protected. Examinations were conducted on smaller tubes with no cathodic protection.

Design considered adequate to preclude need for cathodic protection.

Corrosion-resistant materials used for for fuel assembly and storage system components.

Fuel cladding and $\mathrm{UO}_{2}$ oxidation precluded by low temperatures and helium. Mo isture migration through cracks in concrete prevented by temperature gradient. Asphalt seal used around welded liner seal.

Nickel plate on cask interior; epoxy coating on cask exterior. 
TABLE 9. Cover Gases Used for Dry Storage

\begin{tabular}{|c|c|c|c|c|c|c|c|c|}
\hline \multirow[b]{2}{*}{ Site } & \multirow{2}{*}{$\begin{array}{l}\text { Storage } \\
\text { Facility } \\
\end{array}$} & \multirow{2}{*}{$\begin{array}{c}\text { Type } \\
\text { of } \\
\text { Fuel } \\
\end{array}$} & \multirow{2}{*}{$\begin{array}{c}\text { Type } \\
\text { of } \\
\text { Storage } \\
\end{array}$} & \multirow[b]{2}{*}{ Reference } & \multicolumn{3}{|c|}{ Cover Gas } & \multirow[b]{2}{*}{ Heat Dissipation } \\
\hline & & & & & Inside Fuel Can & Outside Fuel Can & other & \\
\hline I NEL & IFSF & HTGR & Vault & 3 & Air; stagnant & $\begin{array}{l}\text { Air; forced draft, } \\
\text { single pass }\end{array}$ & & $\begin{array}{l}\text { Single-pass air } \\
\text { flow }\end{array}$ \\
\hline INEL & $H F E F / N(a)$ & LMFBR & Vault & 3 & Aryon; air & $\begin{array}{l}\text { Argon and air in } \\
\text { hot cells }\end{array}$ & $\begin{array}{l}w_{2} \text { is possiule } \\
\text { replacement for ar }\end{array}$ & $\begin{array}{l}\text { Recirculate argun } \\
\text { to tleat exchanger }\end{array}$ \\
\hline Wylfa & Cells $1-3$ & Maqnox & Vault & 3,21 & $\begin{array}{l}\mathrm{CO}_{2} \text {, natural } \\
\text { convection }\end{array}$ & $\begin{array}{l}\text { idatural uraft } \\
\text { around tubes }\end{array}$ & $\begin{array}{l}\text { watural urati dir } \\
\text { across storage } \\
\text { tude exteriur }\end{array}$ & \\
\hline Wylfa & Cells 4,5 & Magnox & Vault & 3,21 & $\begin{array}{l}\text { Air; natural con- } \\
\text { vection through } \\
\text { fuel tubes }\end{array}$ & $\begin{array}{l}\text { Air; forced draft } \\
\text { for bulk coolant }\end{array}$ & & $\begin{array}{l}\text { Recirculate air to } \\
\text { heat exchanger } \\
\text { (air to } \mathrm{H}_{2} \mathrm{O} \text { ) }\end{array}$ \\
\hline NTS & $E-M A D$ & PWR & Vault & 14 & Helium & Air & & $\begin{array}{l}\text { Natural or forced } \\
\text { air draft to hot } \\
\text { bay }\end{array}$ \\
\hline INEL & ICPP & HTGR & Dry well & 3 & Helium & Air & & $\begin{array}{l}\text { Passive heat flow } \\
\text { through soil }\end{array}$ \\
\hline I NEL & ICPP & LMFBR & Ory well & 3 & Helium & Air & & $\begin{array}{l}\text { Passive heat flow } \\
\text { through soil }\end{array}$ \\
\hline INEL & RSWF & LMFBR & Dry well & 3 & Argon & Air & $\begin{array}{l}\text { Some EBR-I I blanket } \\
\text { subassemblies stored } \\
\text { in air in dry well }\end{array}$ & $\begin{array}{l}\text { Passive heat flow } \\
\text { through soil }\end{array}$ \\
\hline NTS & E-MAD & PWR & Dry well & 14 & Helium & Air & $\begin{array}{l}\text { Air or vacuum on } \\
\text { one assembly in } \\
\text { brief tests }\end{array}$ & $\begin{array}{l}\text { Passive heat flow } \\
\text { through soil }\end{array}$ \\
\hline NTS & Climax & PWR & Dry well & 14 & Helium & Air & $\begin{array}{l}\text { Air or vacuum on } \\
\text { one assembly in } \\
\text { brief tests }\end{array}$ & $\begin{array}{l}\text { Passive heat flow } \\
\text { through granite }\end{array}$ \\
\hline NTS & $E-M A D$ & PWR & Silo & 14,19 & Helium & Air & & $\begin{array}{l}\text { Passive heat flow } \\
\text { through concrete }\end{array}$ \\
\hline WNRE & AECL & WR-1 & Silo & 3,14 & Hel ium & Air & & $\begin{array}{l}\text { Passive heat flow } \\
\text { through concrete }\end{array}$ \\
\hline WNRE & AECL & CANDU & Silo & 3,14 & Heli ium & Air & & $\begin{array}{l}\text { Passive heat flow } \\
\text { through concrete }\end{array}$ \\
\hline KWW & - & BWR & $\begin{array}{l}\text { Metal } \\
\text { cask }\end{array}$ & $9,12,37$ & $\begin{array}{l}\text { Helium inside } \\
\text { cask }\end{array}$ & $\begin{array}{l}\text { Air outside } \\
\text { cask }\end{array}$ & & $\begin{array}{l}\text { Passive heat flow } \\
\text { through cask walls } \\
\text { and ends }\end{array}$ \\
\hline
\end{tabular}

(a) Storage volumes at HFEF: HFEF/N - air cell $=425 \mathrm{ml}^{3}$; aryon cell $=1407 \mathrm{ml}^{3}$

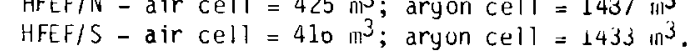


Radiation Readings

A major consideration in the design and operation of dry storage facilities is the control of radiation exposure to workers. Radiation data from various sites (Table 10) indicate that even with high radiation sources inside the facilities all types of dry storage systems can be designed to control radiation doses to safe levels. A summary of radiation levels at the wylf a vault facility is given below:

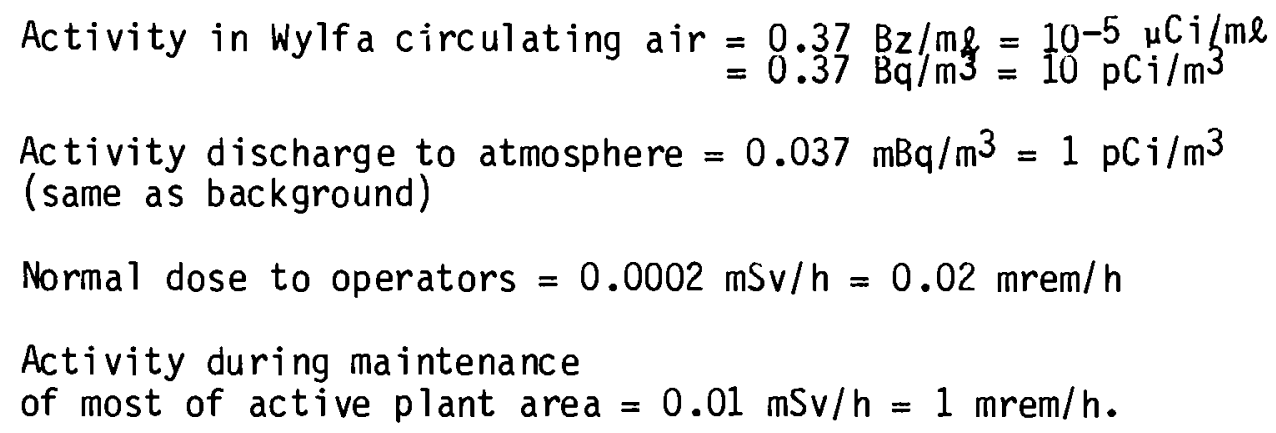

A summary has been published of the radiation doses to the Atomic Energy of Canada Ltd. (AECL) operational staff who participated in loading the concrete silos at WNRE. (3) The fuel loading operations resulted in 0.83 rem for one canister and 0.50 rem for another. Loading and welding baskets in the hot cell accounted for the largest doses while transferring the fueled baskets to the storage site and loading the canisters into the silos accounted for small fractions of the total doses. The Wylfa vault facility has operational doses that are approximately one-third those for equivalent wet storage facilities. Monitoring System Integrity

Various methods are used to monitor the performance of systems (e.g., cooling systems) and the level of mobile radiation that would signal a cladding and/or container failure (see Table 11).

In addition to the information presented here, considerable additional information of potential value to dry storage facility designers and operators is available from the operational facilities. $(3,11,12)$ This information inc ludes: 


\section{TABLE 10. Radiation Levels at Dry Storage Facilities}

$\frac{\text { Site }}{\text { INEL }} \frac{\begin{array}{l}\text { Storage } \\ \text { Facility }\end{array}}{\text { IFSF }} \frac{\begin{array}{c}\text { Type } \\ \text { of } \\ \text { Fuel }\end{array}}{\text { HTGR }} \frac{\begin{array}{c}\text { Type of } \\ \text { Storage }\end{array}}{\text { Vault }} \frac{\text { Reference }}{3}$

Wylfa Cells 1-5 Magnox Vault

\section{$E-M A D$}

PWR

INEL ICPP

$\omega$
INEL ICPP HTGR Dry wel

INEL RSWF

LMFBR

Dry wel

NTS

NTS

NTS E-MAD

WNRE AECL

WRNE AECL

$\mathrm{KWW}$

\section{Vault}

\section{4}

At vault outer wall

Above shield plug

Above shield plug

Above dry wells

Above shield plug

At silo wall (eye

leve 1 )

14

Outer surface of silo

Outer surface of silo

Outer surface of cask
General

Radiation

Reading, mrem $/ \mathrm{h}$ Remarks

For source of $50,000 \mathrm{rem} / \mathrm{h}$ inside window ( $1.3 \mathrm{~m}$ thick).

Sources $10^{4}$ to $10^{6} \mathrm{rem} / \mathrm{h}$ inside cell; walls, $1.2 \mathrm{~m}(4 \mathrm{ft})$ thick.

$<1$

$<0.03(<0.01$ for cells 4,5

alls $2 \mathrm{~m}(6.5 \mathrm{ft})$ thick; occupational doses lower than equivalent pool storage; number of operators is $1 / 3$ of requirement for equivalent pool storage.

Background

0.1

Background

$<1$ to $45(<1$ $\mathrm{mrem} / \mathrm{h}$ at $3 \mathrm{ft}$ above surface)

Readings taken at surface of shield plug $(0.7 \mathrm{mrem} / \mathrm{h})$.

At top of Fermi plug $(0.6 \mathrm{~m}$ or $2 \mathrm{ft}$ of concrete).

At top of HTGR plug $(1.2 \mathrm{~m}$ or $4 \mathrm{ft}$ of concrete).

Readings taken September 1979.

0.1 (b)

0.3

14

5

$<10$ on cask outer surface
Designed to limit surface dose to $<20 \mathrm{mrem} / \mathrm{h}$.

Readings taken af ter fuel loaded (1975).

Readings taken after fuel loaded (1976).

16 BWR fuel assemblies in cask; cooled $\sim 1 \mathrm{yr}$.

(a) $1 \mathrm{mrem} / \mathrm{h}=0.01 \mathrm{mSv} / \mathrm{h}$.

(b) 1982 . 


\section{TABLE 11. Methods to Monitor Dry Storage System Integrity}

\begin{tabular}{|c|c|c|c|c|c|c|c|c|c|}
\hline & \multirow[b]{2}{*}{$\begin{array}{l}\text { Storage } \\
\text { Facility }\end{array}$} & \multirow{2}{*}{$\begin{array}{c}\text { Type } \\
\text { of } \\
\text { Fuel } \\
\end{array}$} & \multirow[b]{2}{*}{$\begin{array}{l}\text { Type of } \\
\text { Storage }\end{array}$} & \multirow[b]{2}{*}{ Reference } & \multicolumn{2}{|c|}{ Temperature } & \multicolumn{2}{|c|}{ Radiation Levels } & \multirow[b]{2}{*}{ Other Monitoring } \\
\hline & & & & & $\begin{array}{l}\text { Cover } \\
\text { Gas }\end{array}$ & Fuel & Cover Gas & Uther & \\
\hline$\overline{\text { INEL }}$ & $\overline{\text { IFSF }}$ & HTGR & Vault & 3 & $\overline{\operatorname{TCs}(a)}$ & Test rig & & Air flow rate. & \\
\hline INEL & HFEF/N & LMFBR & Vault & 3 & TCs & $\begin{array}{l}\text { Visual } \\
\text { inspection } \\
\text { af ter } \\
\sim 6 \text { months }\end{array}$ & $\begin{array}{l}\text { In-cell filters, } \\
\text { radiation moni- } \\
\text { tors, and grab } \\
\text { samples }\end{array}$ & $\begin{array}{l}\text { Alpha; } \beta / \text { fixed } \\
\text { sampling stations }\end{array}$ & 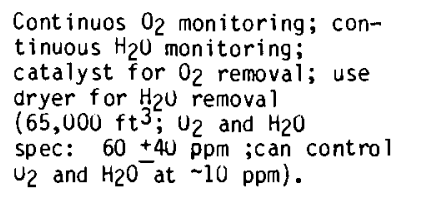 \\
\hline Wylfa & Cells $1-3$ & Magnox & Vault & 3,14 & TCs & - & $\begin{array}{l}\text { Purity checks } \\
\text { once a week }\end{array}$ & & $\begin{array}{l}\text { Fuel examined after } 4 \text { yr; } \\
\text { r level to select fuel for air } \\
\text { cell; } \Delta \text { P for inleakage; humidity } \\
\text { monitoring. }(b)\end{array}$ \\
\hline Wy if a & Cel1s 4,5 & Magnox & Vault & 3,14 & TCs & $\begin{array}{l}\text { TCs on can- } \\
\text { isters }(b, c)\end{array}$ & $\begin{array}{l}\text { Gas and particu- } \\
\text { late cont inuous } \\
\text { monitoring }\end{array}$ & & Tis in flow path of vault air. \\
\hline NTS & E-MAD & PWR & Vault & 14 & TCs & $\begin{array}{l}\text { TCs on } \\
\text { canisters }\end{array}$ & & & \\
\hline \multirow[t]{8}{*}{$\underline{w}$} & ICPP & HTGR & Dry well & 3 & TCs & -- & $\begin{array}{l}\text { Periodic gas } \\
\text { samples }\end{array}$ & $\begin{array}{l}\text { Health physics } \\
\text { monitoring }\end{array}$ & Periodic humidity monitoring. \\
\hline & ICPP & LMFBR & Ory well & 3 & TCs & & $\begin{array}{l}\text { Periodic gas } \\
\text { samples }\end{array}$ & $\begin{array}{l}\text { Health physics } \\
\text { monitoring }\end{array}$ & Periodic numidity monitoring. \\
\hline & RSWF & LMFBR & Dry well & 3 & -- & & -- & -- & $\begin{array}{l}\text { Enviromental (air and soil) } \\
\text { monitoring. }\end{array}$ \\
\hline & E-MAD & PWR & Dry well & 14 & -- & $\begin{array}{l}\text { TCs on } \\
\text { canisters }\end{array}$ & -- & $\begin{array}{l}\text { Health physics } \\
\text { monitoring }\end{array}$ & \\
\hline & Climax & PAR & Dry well & 14 & -- & $\begin{array}{l}\text { TCs on } \\
\text { canisters }(b)\end{array}$ & -- & $\begin{array}{l}\text { Health physics } \\
\text { monitoring }\end{array}$ & \\
\hline & $E-M A D$ & PWR & Silo & 14,19 & - & $\begin{array}{l}\text { TCs on } \\
\text { canisters }\end{array}$ & -- & $\begin{array}{l}\text { Health physics } \\
\text { monitoring }\end{array}$ & $\begin{array}{l}\text { Strain gages mounted in silo; } \\
\text { marginally effective. }\end{array}$ \\
\hline & AECL & CANDU & Silo & 3,14 & -- & $\begin{array}{l}\text { TCs to fuel } \\
\text { and baskets }\end{array}$ & $\begin{array}{l}\text { Fission product } \\
\text { monitors for } \\
\text { fuel baskets }\end{array}$ & $\begin{array}{l}\text { B/r monitoring } \\
\text { of nearby } \\
\text { surf ace waters }\end{array}$ & $\begin{array}{l}\text { Strain gages in concrete and } \\
\text { reinforcing steel. Kadiation } \\
\text { alarms on facility tence. } \\
\text { lAEA seals on fueled silos. } \\
\text { Pre-examination of fuel in } \\
\text { hot cell. }\end{array}$ \\
\hline & - & BWR & $\begin{array}{l}\text { Metal } \\
\text { cask }\end{array}$ & $9,12,37$ & -- & TCs on fuel & & & $\begin{array}{l}\mathrm{N}_{2} \text { lid cover gas monitored } \\
\text { for } \mathrm{N}_{2} \text { pressure reduction. }\end{array}$ \\
\hline
\end{tabular}

(a) TCS $=$ thermocouples.

air is bypassed into cooling coils to remove water; the volume and activity level are measured. Moisture levels during noma

(c) Fuel cladding temperatures est imated by precal ibration with electrical heaters. 
- detailed safety analyses

- experience with operation of iodine and high-efficiency particulate air (HEPA) filters $(a)$

- design redundancy for key systems

- identification and assessment of design base accidents

- assessment of times to unload casks and place fuel in storage locations

- impacts of power failures and demonstration of successful performance of emergency power systems

- monitoring and control of impurities in inert gas systems.

\section{INTEGRITY OF DRY STORAGE FACILITIES}

Although the demonstrations and tests have been designed to emphasize investigations of fuel cladding integrity, the integrity of the storage facility and its components is also important. Dry storage studies should include assessments of the integrity of the storage facility and its components. This section discusses facility integrity for dry wells, vaults, silos, and metal casks.

The integrity of water reactor fuel is being investigated in facilities representing all four dry storage concepts. It is important to recognize that fuel behavior in one concept is generally applicable to other concepts at comparable temperatures and environments.

Dry Wells, Vaults, and Silos

Dry storage facilities generally use reinforced concrete as the principal containment. Concrete durability has been addressed to some extent in WNRE and NTS studies; ${ }^{(3)}$ corrosion considerations for storage components were discussed in Table 8. Dry well, vault, and silo facilities are functioning with only minor operational problems. Dry wells rate relatively well in cost

(a) At the Wylfa air-cooled facility (cells 4,5) filters have been used since 1979 without accumulating significant contamination. 
assessments compared to vaults and silos; ${ }^{(6)}$ dry wells, however, present some siting problems where ground waters are close to the surface.

\section{Metal Casks}

Technical-scale use of large metal casks for extended interim fuel storage will begin in the near future. Metal casks have been used for shipping irradiated fuel since the mid-1940s. Thousands of water reactor fuel assemblies have been shipped in single-assembly and multiassembly casks over the past two decades. Metal cask integrity in routine operations has been excellent. Metal casks have survived accident testing that has included fire, crash, and drop tests.

Table 12 summarizes information regarding metal cask characteristics. Not all of the cask models shown in the table have been built. The table illustrates the variety of cask sizes that are being offered.

Cask loading is an important consideration in preparing for dry cask storage of water reactor fuel. Loading of single-assembly and multiassembly casks underwater is a routine operation at wet storage facilities. At storage pools with ample crane capacities, in-pool loading of the larger storage casks is also a logical approach. For example, a CASTOR 1C cask was loaded with 16 BWR assemblies in the KWW reactor pool. (9) After loading, the water was removed from the cask interior and replaced with helium.

Crane capacities at U.S. reactor pools range from 23 to 164 tonnes. However, redundancy in the crane suspension system is another consideration. At least 10 U.S. reactors have met the intent of single-failure-proof requirements. (41)

Plans are under way at the Swiss DIORIT test reactor to load casks under dry conditions. (20) Concepts are also under development in the United States for spent fuel transfer equipment that would permit cask loadings under dry conditions.

\section{Metal Cask Characteristics}

Dry wells, vaults, and silos have been in extended service for storage of irradiated fuel (see Tables 6 through 10 ). This section provides background inf ormation on metal casks. 


\section{TABLE 12. Storage Cask Status}

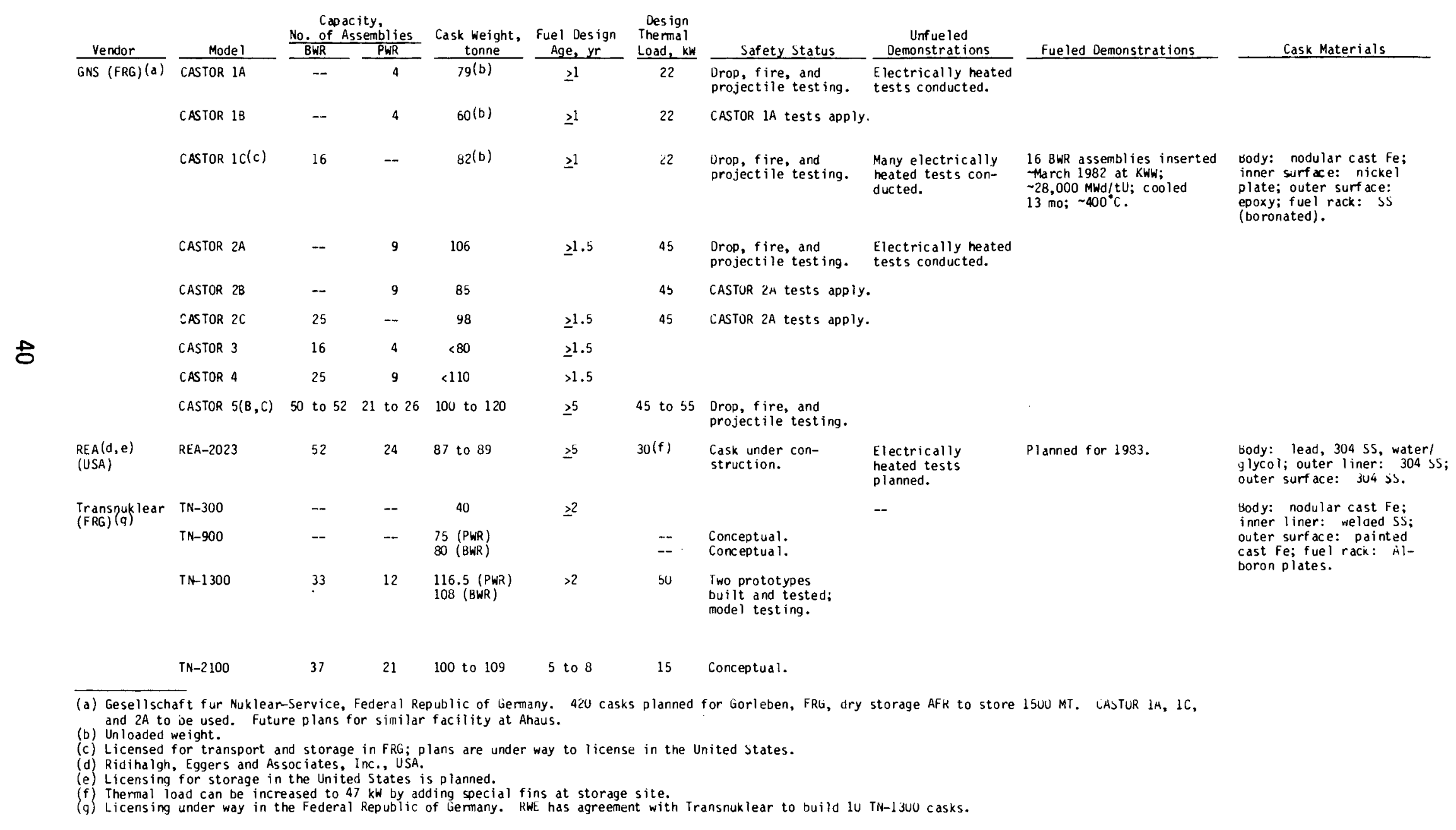


Several U.S. suppliers offered bids to construct a cask for a dry storage demonstration using Zircaloy-clad LWR fuel. The cask was commissioned by DOE, and the successful bidder was Ridihalgh, Eggers and Associates, Inc. (REA). The cask is scheduled for delivery in December 1982. Whether to design casks for storage only is a point still being considered among U.S. storage cask designers. For shipments of storage-only casks, overpacks (metal shells) may be added without removing the fuel from the metal cask; alternative designs propose adding 1 imiters for shipment.

The key aspects of storage cask development are summarized below:

- Multiassembly cast iron casks were licensed in the Federal Republic of Germany for shipment early in 1981 and for a dry storage demonstration at KWW later in 1981. The licensing process included electrically heated thermal assessments, drop tests, crash tests, and fire tests.

- The first demonstration of irradiated fuel storage in a met 1 cask began in February 1982 at KWW; ${ }^{(9)} 16$ unc anistered BWR assemblies are stored in a CASTOR $1 \mathrm{C}$ cask. The assemblies had been stored $\sim 1 \mathrm{yr}$ in water prior to cask storage. Fuel burnup was $\sim 27,000 \mathrm{MWd} / \mathrm{tU}$, and the maximum fuel $\mathrm{cladding}$ temperature in the cask was $-385^{\circ} \mathrm{C}$ on a few center rods. Temperatures on peripheral rods were as low as $\sim 180^{\circ} \mathrm{C}$.

- Prior cask storage demonstrations have been conducted with electrically heated fuel assemblies.

- Construction has begun in the Federal Republic of Germany for a dry storage away-from-reactor (AFR) facility at Gorleben. The facility is scheduled for completion at the end of 1983 and is expected to involve up to 420 metal casks for storage of $1500 \mathrm{tU}$ of LWR fuel. A second dry storage AFR site at Ahaus ( $F R G)$ is in an advanced stage of licensing.

- The three cask suppliers listed in Table 12 offer a variety of cask sizes; they represent only a fraction of the companies that have indicated interest in supplying fuel storage casks. 
Shipping Cask Safety Testing

Metal shipping casks have performed as predicted in numerous safety assessments and demonstrations, including the following: ${ }^{(42)}$

- Cask-bearing trucks hit a concrete wall at 96 and $135 \mathrm{~km} / \mathrm{h}$ (60 and $84 \mathrm{mph})$.

- A cask-bearing truck was hit by a train at $129 \mathrm{~km} / \mathrm{h}$ (80 mph).

- A cask-bearing rail carrier hit a concrete barrier at $130 \mathrm{~km} / \mathrm{h}$ (81 mph).

- A cask survived a fire with temperatures of $\sim 980$ to $1150^{\circ} \mathrm{C}$ (1800 to $2100^{\circ} \mathrm{F}$ ) for $90 \mathrm{~min}$.

- A cask survived a drop from $600 \mathrm{~m}(2000 \mathrm{ft})$ onto desert hardpan. (43)

- Casks have survived impacts by high-speed projectiles.

\section{Cask Materials}

The internal surfaces of the cask body are generally stainless steel or nickel plate. The surfaces will be subject to temperatures somewhat below maximum cladding temperatures. Fuel rack materials for storage casks include: aluminum, aluminum/B4C compacts, and stainless steel (see Table 7).

In inert atmospheres, corrosion of cask interior surfaces by low levels of impurities $\left(\mathrm{H}_{2} \mathrm{O}, \mathrm{CO}, \mathrm{CO}_{2}\right.$, etc.) would be nil. In air, all exposed surfaces (aluminum, nickel, stainless stee 1 ) have excellent resistance to oxidation in dry air at 250 to $400^{\circ} \mathrm{C}$. If moisture is present in the air, some radiationinduced nitric acid formation is possible. Methods are available to dry the cask atmospheres after loading in a spent fuel pool; however, drying procedures and acceptable residual moisture levels need better definition. Commercial shipping casks subjected to many wetting and drying cycles have functioned for up to two decades without significant degradation.

Radiation damage to dry storage facility materials will be inconsequential. Neutron fluences will be $\sim 10^{14} \mathrm{n} / \mathrm{cm}^{2}$ in $40 \mathrm{yr}$ at the cladding surface. 
Neutron doses to the cask would be below thresholds for significant metallurgical degradation. Gamma fluxes will also not cause significant metallurgical degradation of cask or container materials.

Figure 8 shows a mild steel (alloy A36) shipping cask used to transfer irradiated fuel at Hanford. The cask was first used in the mid-to-late 1940s and is still serviceable. It is one of the oldest casks used for irradiated fuel transport; however, it is not licensed for highway transport. The mild steel cask body has been repainted two or three times during its years of use, and it has been subjected to numerous wetting and drying cycles during fuel movement. This duty constitutes more severe environmental conditions than is likely to occur for metal dry storage casks, which are not subject to alternate

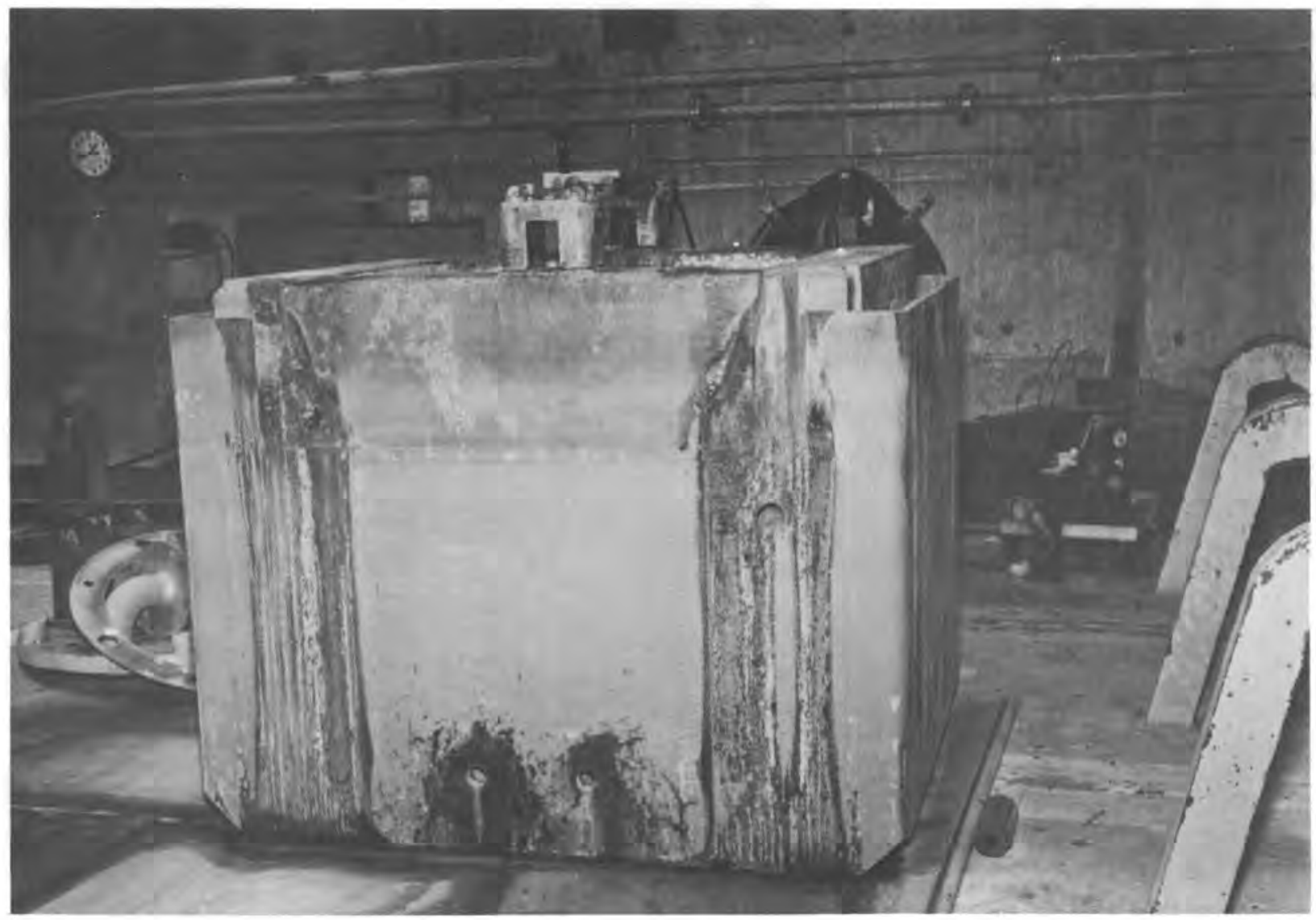

Neg. 27038-2

FIGURE 8. Mild Steel Shipping Cask for Irradiated Fuel (used at Hanford Reservation since 1940s) 
wetting and drying. In fact, while the heat from the fuel maintains cask exterior surface temperatures above the dew point, the elevated temperature will be beneficial. There is substantial evidence that holding metal temperatures above the dew point minimizes corrosion by eliminating condensed moisture from the corrosion environment.

In summary, mild steel casks have operated for up to nearly four decades for local transport of irradiated fuel at Hanford; and licensed SS commercial fuel shipping casks have operated for approximately two decades. Cask degradation does not appear to be a problem due to corrosion or other types of metal failure.

Decommissioning Aspects of Dry Storage Facilities

All of the facilities used for dry storage of irradiated fuel are still in operation; thus, there is no direct decommissioning experience for dry storage facilities. However, the HFEF/S (see Table 7) was decontaminated and refurbished. (44) Decontamination techniques for the nickel-plated irner surfaces of some casks have been assessed. (45) Numerous procedures for decontaminating concrete and metal structures are in advanced stages of development. (46)

\section{OVERVIEW OF DRY STORAGE EXPERIENCE}

Operating information is available from fueled dry well, silo, vault, and metal cask storage facilities. Maximum operational histories are:

\begin{tabular}{|c|c|c|}
\hline & A11 Fue 1 & Zircaloy-Clad Fuel \\
\hline Dry wells & up to $18 \mathrm{yr}$ & up to 3 to $4 \mathrm{yr}$ \\
\hline Vaults & up to $18 \mathrm{yr}$ & up to $1 \mathrm{yr}$ \\
\hline Silos & up to $7 \mathrm{yr}$ & up to $7 \mathrm{yr}$ \\
\hline Metal casks & - & $<1 \mathrm{yr}$ \\
\hline
\end{tabular}

All times relate to 1982 . 
Operational history with interim storage in metal casks is minimal; however, there is extensive experience with metal shipping casks. In addition, metal storage casks have been designed and tested, and cask tests with irradiated fuel are currently under way in the Federal Republic of Germany and are planned in Switzerland and the United States. The integrity of Zircaloy-clad fuel in a given demonstration test is relevant to predicting fuel behavior in other dry storage concepts under similar conditions.

Dry wells, vaults, and silos have operated with irradiated fuel without problems. The following favorable operational history is notable:

- Fuel has been emplaced and retrieved from dry wells, vaults, and silos without damage.

- Passive cooling of dry wells, silos, casks, and certain vault facilities has been demonstrated.

- Redundant equipment and emergency power supplies have avoided any serious coolant interruption in forced draft vault installations.

- Satisfactory fuel cladding temperatures have been maintained in passively cooled interim storage facilities.

- Serious corrosion or other fuel or equipment degradation has not occurred at any dry storage installation.

- Radiation levels in work areas have been low.

- Several cover gases (including air, argon, carbon dioxide, helium, and nitrogen) have performed satisfactorily.

- Several types of fuel have been stored successfully, including GCR, LMFBR, organic-cooled reactor (OCR), PHWR, BWR, and PWR fuel.

- Demonstrations and technical studies are under way in several countries to qualify Zircaloy-clad water reactor fuel for licensed dry storage. 



\section{ASSUMPTIONS REGARDING SPENT FUEL AND DRY STORAGE CONDITIONS}


Spent fuel characteristics and expected storage conditions must be defined to focus assessments and experimental programs on regimes that will be relevant to actual dry storage conditions. This section briefly addresses the characteristics of water reactor fuel and the expected conditions for dry storage. Appendix $C$ provides a more detailed discussion of water reactor fuel characteristics.

- Time in water storage before placement in dry storage: probably $>5 \mathrm{yr}$ for early dry storage of U.S. LWR fuel. A substantial fraction of U.S. fuel has been in water storage for $10 \mathrm{yr}$ or longer, which suggests that relatively old fuel can be selected for dry storage. In some countries, older fuel has been shipped to reprocessing sites, leaving remaining at-reactor inventories with relatively short cooling times.

- Maximum cladding temperatures: Investigations are under way that will provide a basis to establish maximum acceptable temperatures. Analyses by FRG and U.S. investigators suggest that Zircaloy-clad fue 1 can be in inert gases at maximum temperatures of 385 to $400^{\circ} \mathrm{C} .(12,17) \mathrm{Cl}$ adding temperature estimates from E-MAD dry well and silo tests suggest that a large fraction of the U.S. LWR inventory can be stored below $200^{\circ} \mathrm{C}$ in similar facilities. Fuel oxidation studies are under way that will provide a basis to establish a temperature limit in oxidizing cover gases. Temperature effects above the 1 imits need to be investigated to address overtemperature conditions. Cladding temperatures will decrease as the fuel ages; temperature gradients will exist within the dry storage facility. While some isothermal testing is required to define specific phenomena, dry storage demonstrations should generally be conducted under decreasing temperatures that are characteristic of diminishing decay heats. 
- Storage atmosphere: The use of inert cover gases (He, Ar) is being demonstrated in some dry storage programs; air, $\mathrm{CO}_{2}$, and $\mathrm{N}_{2}^{(a)}$ are being used in others. Some U.S. utilities prefer to demonstrate the viability of storage in unlimited air so that the need to monitor inert cover gases is obviated. Maximum tolerable residual moisture levels from underwater fuel loading operations need to be defined, and appropriate drying techniques need to be identified.

- Fuel pressurization:

- Dry storage may involve older U.S. LWR fuel that was not prepressurized prior to reactor exposure. Fission gases also contribute to fuel rod pressures, but fission gas pressures will be relatively low for fuel with lower burnups.

- Prepressurized fuel may also be a candidate for early storage. Helium fill gas pressures range from 15 to $30 \mathrm{~atm}$ for PWR fuel and 1 to $6 \mathrm{~atm}$ for BWR fuel (pressurized at room temperature). When fission gas pressures are included, PWR rod pressures can range up to $65 \mathrm{~atm}$. Typical end-of-1ife pressures are $\sim 30$ to $40 \mathrm{~atm}$ for PWR fuel and $15 \mathrm{~atm}$ for BWR fuel (a11 pressures relate to room temperature).

- Hoop stresses due to internal rod pressures will not be opposed in dry storage by reactor system pressures as they are during reactor operation. Resultant cladding hoop stresses from the internal rod pressures are being investigated in dry storage demonstrations and tests.

- Cladding types: Zircaloy-clad fuel renresents $>95 \%$ of the stored U.S. LWR fuel inventory; SS-clad fuel accounts for the remaining inventory. Zircaloy-clad fuel wiil nave a correspondingly higher priority in dry storage demonstrains.

(a) $\mathrm{N}_{2} \mathrm{can}$ interact with $\mathrm{H}_{2} \mathrm{O}$ to form $\mathrm{HNO}_{3}$ by radiolysis; otherwise, $\mathrm{N}_{2}$ is $\mathrm{far}$ less reactive than $0_{2}$ with Zircaloy cladding and other dry storage system materials. 
- Fuel types: In the United States and the Federal Republic of Germany, both BWR and PWR fuels will be candidates for dry storage. Because crud, cladding thickness, fuel pressurization, etc., differ for BWR and PWR fuel, both fuel types need to be evaluated. PHWR and WR-1 fuels are in dry storage demonstrations in Canada.

- Cladding mechanical properties: Neutron irradiation decreases cladding ductility and increases cladding strength; but sufficiently severe time-temperature exposures will tend to anneal the radiation damage, thus increasing ductility and decreasing strength. For example, sufficiently long exposures at $400^{\circ} \mathrm{C}$ will anneal radiation effects in Zircaloy cladding. Testing regimes should address cladding conditions that will exist in dry storage. In some cases, the conditions will include temperatures where substantial annealing of radiation effects may occur; in other storage regimes, radiation effects may remain largely intact.

- Cladding defects:

- Early LWR fuel had a higher incidence of cladding failures during reactor operation than more recent fuel generations. However, the older fuel has longer storage times and generally lower burnups, which result in lower decay heats and correspondingly lower storage temperatures.

- While fuel with obvious defects may be excluded from dry storage, exclusion of all defects cannot be guaranteed by current inspection methods. (47) Therefore, the consequences of storing fuel with through-wall defects are being evaluated. Impacts of storing fuel with cladding defects are likely to be minor in nonoxidizing gases or at temperatures below the threshold for significant fuel oxidation in oxidizing environments.

- Incipient cladding defects ${ }^{(a)}$ are known to occur in Zircaloyclad fuel, although infrequently. The consequences of incipient defects should be evaluated in dry storage integrity investigations.

(a) Defects that have progressed only part way through the cladding walls. 
- Fuel packaging for dry interim storage: Fuel has been enclosed in metal canisters before emplacement in dry wells and silos. Some fuel is placed in vaults in open baskets; some fuel, in closed canisters. Metal storage casks are currently being evaluated on the basis that the fuel would not require canning.

- Fuel crud: Surface crud on the fuel rods will be carried into the dry storage chambers, and extended exposures to elevated temperatures may cause some crud to spall. Possible impacts of the crud during fuel retrieval and facility decommissioning need to be defined. The effects of crud on fuel rod emissivities should be factored into heat transfer models.

- Storage times: Fuel may remain in dry storage over the period of a reactor license (up to $\sim 40 \mathrm{yr}$ ) or unt 11 reprocessing and/or permanent disposal options are available.

- Fuel retrievability: Fuel must be retrievable from the interir storage facility. Whether canned fuel must be retrievable from the canister remains to be defined; an overpack for the canister may be suitable for permanent disposal. Whether the canister must be removed before reprocessing depends on canister material and geometry; some reprocessing facilities could accommodate thin-walled SS canisters of square cross section, but round geometries and low alloy steels may present processing difficulties. Currently, the base case for geologic disposal of spent fuel involves consolidated fuel. If fuel is consolidated prior to dry storage, removal from the storage canister may not be necessary prior to geologic disposal. If necessary, the interim storage canister could be placed in an overpack. There is a substantial probability, however, that some unconsolidated fuel will be placed in dry storage; therefore, the fuel may need to be retrievable from the canister after interim storage for consolidation prior to geologic disposal if that mode develops for some or all water reactor fuel. 
- Fuel handling: Some fuel may be placed in dry storage at the reactor where it is discharged; other fuel may be shipped (wet or dry) to a dry storage location. If the fuel is shipped dry, crud characteristics may change, which is not necessarily a major consideration for storage but could be a consideration in assessing crud characteristics on test rods. Mechanical damage during fuel loading or retrieval does not currently appear to present a significant degradation mechanism based on substantial wet and dry shipping experience. (34)

- Monitoring the dry storage facility:

- Dry storage demonstrations need direct monitoring to establish temperature correlations; development of satisfactory benchmarks and codes will minimize or preclude a need for direct temperature monitoring in licensed storage. The need to monitor storage facility cover gases will depend on the storage concept and the fuel temperature. A German cask monitoring concept involves monitoring for leaks between the first and second cask lids to avoid making a direct penetration into the cask. (9)

- Fuel consolidation: Both unconsolidated and consolidated fuel may become candidates for dry storage.

- Probable integrity issues in hearings:

- What are the potential mechanisms for cladding degradation during dry storage? What would be the consequences of cladding failure?

- Will reactor-induced defects propagate under dry storage conditions? If so, what will be the consequences?

- What will be the integrity of the facility? of the canister if fuel is canned? Are degradation mechanisms possible over the expected storage 1 ife?

- Are accidents credible that could breach facility and cladding integrity? 
- What are the impacts of crud spallation during storage? During fuel retrieval? During decomissioning?

- How will fuel storage atmospheres and conditions be defined and monitored? 
FUEL AGES AND DECAY HEATS 


\section{FUEL AGES AND DECAY HEATS}

Residual decay heat in spent fuel at the time it is placed in dry storage is a key aspect in designing the dry storage facility and defining the maximum dry storage temperature. In several other countries, older LWR fuel inventories have been shipped to reprocessing plants; therefore, the spent fuel remaining in the reactor pools tends to have relatively short cooling times and high decay heats. Canadian CANDU fuel is discharged with relatively low burnups, and a substantial fraction of the inventory has relatively long cooling times in wet storage. No U.S. LWR fuel has been reprocessed since 1971; therefore, a large fraction of the U.S. inventory has relatively long cooling times (Figure 9) and low decay heats (Figure 10).

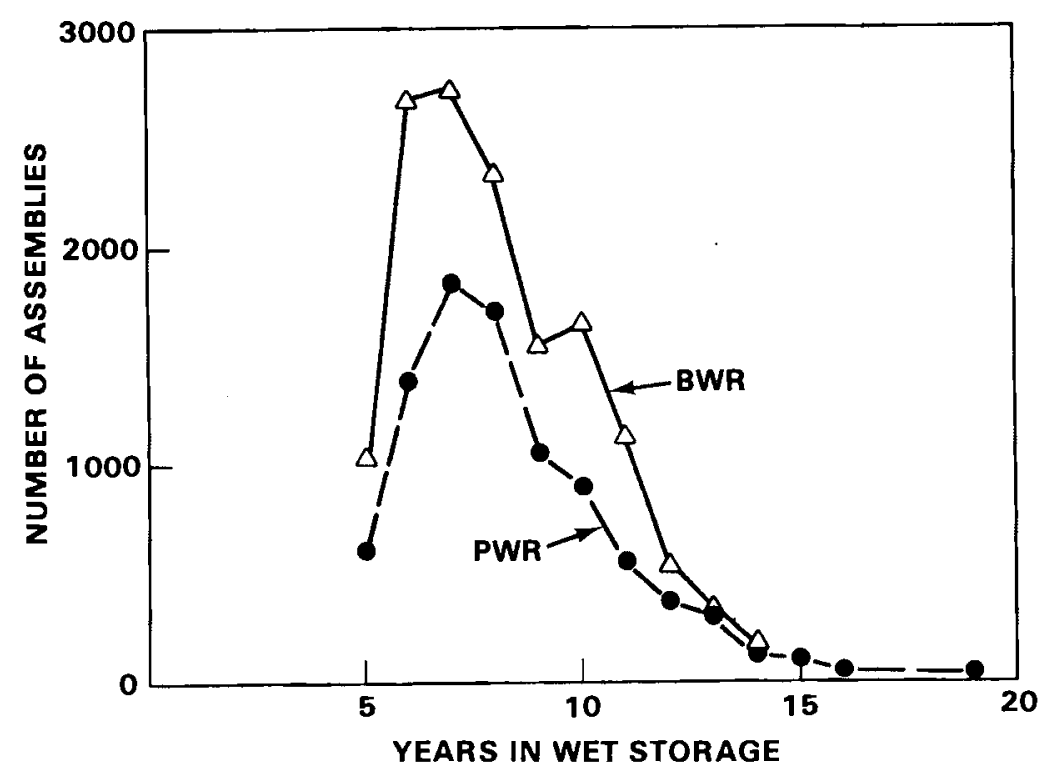

FIGURE 9. Distribution of Wet Storage Times for U.S. LWR Spent Fuel Inventories Discharged as of December 1980 and Projected to 1986 . Zircaloy-clad fuel discharged in $1959(49)$ is not included in this inventory. 


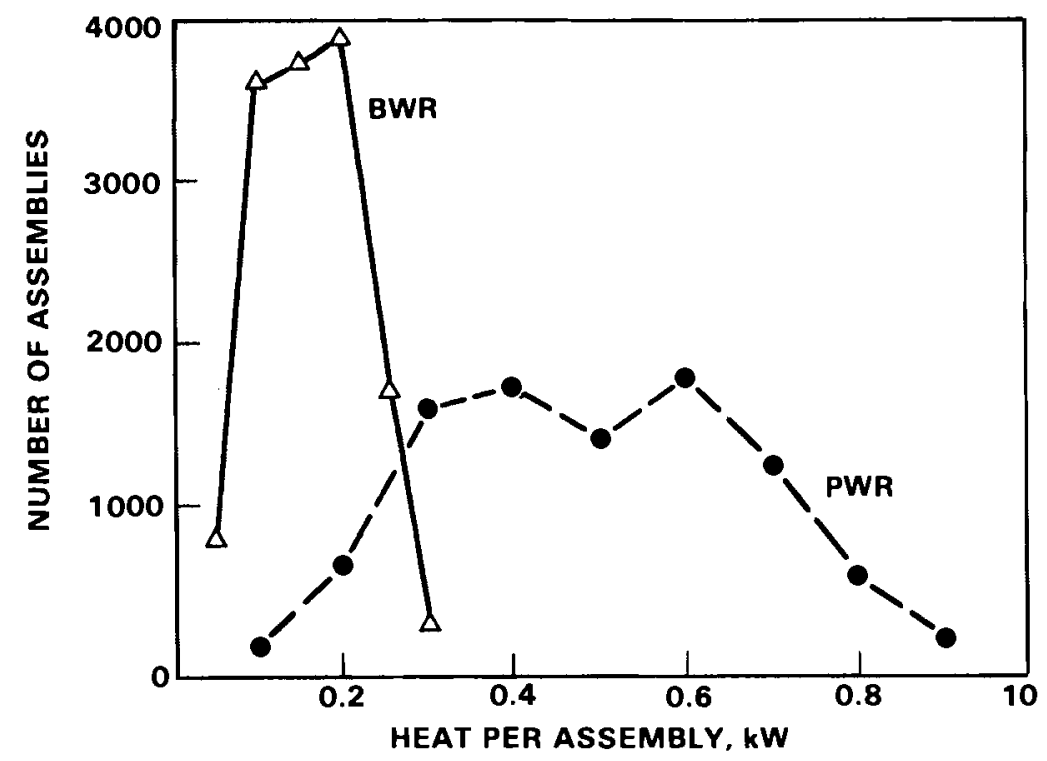

FIGURE 10. Distribution of Decay Heats for U.S. LWR Spent Fuel Inventories Discharged as of December 1980 and Projected to 1986

\section{U.S. FUEL INVENTORY PROJECTIONS}

The data plotted in Figures 9 and 10 are based on the U.S. spent fuel inventory in storage at the end of 1980 . The inventory characteristics were projected forward to 1986 to provide a basis to assess the inventory at the time that some U.S. reactors will begin to deplete current storage capacities. (a) No fuel discharged after 1980 is included in the assessment, and the estimates of kilowatts per assembly are based on the ORIGEN code. (48) The lower average decay heats per assembly for BWR fuel arise from lower uranium inventories per assembly: $\sim 190 \mathrm{~kg}$ for BWR fuel and $\sim 460 \mathrm{~kg}$ for PWR fuel. Burnups also tend to be lower for BWR fuel. The assessments summarized in Figures 9 and 10 may be subject to some adjustments since quality assurance checks are under way on the computerized fuel inventory.

Characteristics of the U.S. fuel inventory provide flexibility for implementing dry storage:

(a) At least one U.S. reactor has recently revised to 1984 the date that current storage capacities will be depleted. 
- PWR fuel with decay heats less than $0.65 \mathrm{~kW}$ may be storable in casks at temperatures below $200^{\circ} \mathrm{C}$, although this is a highly preliminary estimate that should be conf irmed by instrumented multiassembly cask tests; corresponding estimates have not yet been made for BWR fue 1 .

- At relatively low temperatures, successful fuel storage in air appears to be a reasonable expectation. Fuel cladding defects are less likely to present storage problems at temperatures where oxidation of exposed $\mathrm{UO}_{2}$ occurs very slowly.

- The LWR fuel inventory with low heat ratings offers good prospects for rod consolidation prior to dry storage while maintaining satisfactory storage temperatures.

Inspection of projected storage inventory characteristics for U.S. reactors indicates that all the reactors that will begin to deplete storage capacities from 1984-1986 will have substantial fuel inventories with decay heats of $0.5 \mathrm{~kW}$ or below. Dry storage at moderate temperatures is a good irospect for older fuel from those reactors.

\section{FUEL CLADDING TEMPERATURE PROJECTIONS}

The maximum acceptable dry storage temperatures for Zircaloy-clad water reactor fuel must be established. Assessments suggest that in inert cover gases maximum fuel cladding temperatures from 385 to $400^{\circ} \mathrm{C}$ are likely to be acceptable, $(37,39)$ and dry storage demonstrations are under way to investigate Zircaloy cladding behavior in that temperature regime. However, projections of heat ratings of the U.S. fuel inventory in 1986 suggest that much of the fuel can be stored at lower temperatures (see Figure 10).

Maximum cladding temperatures on PWR assemblies in E-MAD surface dry well tests were $226^{\circ} \mathrm{C}$, which corresponds to a decay heat of $1.2 \mathrm{~kW}$, and $178^{\circ} \mathrm{C}$, which corresponds to a decay heat of $0.9 \mathrm{~kW} .(2)$ The data in Figure 10 suggest that dry wells similar to those at E-MAD ${ }^{(18)}$ can store essentially all of the 1980 U.S. PWR inventory below $\sim 200^{\circ} \mathrm{C}$ by 1986 , and storage of much of the fuel appears possible at considerably lower temperatures. Similar conclusions are likely to emerge from an assessment of storage temperatures for BWR assemblies. 
The maximum cladding temperature for a PWR assembly stored in an E-MAD silo was $150^{\circ} \mathrm{C}$, which corresponds to a decay heat of $0.8 \mathrm{~kW}$. (a) Thus, a major fraction of the 1986 U.S. PWR inventory can be stored below $150^{\circ} \mathrm{C}$ in a silo of the E-MAD design.

Actual temperature-decay heat correlations are not yet available for water reactor fuel in metal casks and storage vaults. However, the conclusion for these storage facilities is likely to be similar to the conclusion for dry wells and silos. A major fraction of the U.S. LWR spent fuel inventory can be stored at relatively low temperatures.

(a) Based on data supplied by R. Unterzuber of Westinghouse-AESD, Pittsburgh, Pennsylvania. 
FACTORS INFLUENCING FUEL ASSEMBLY PERFORMANCE IN DRY STORAGE 
FACTORS INFLUENCING FUEL ASSEMBLY PERFORMANCE IN DRY STORAGE

Information regarding dry storage characteristics of Zircaloy-clad fuel is developing from dry storage demonstrations and tests on irradiated fuel assemblies and rods. However, assessment of the existing large data base for zirconium alloys has several potential values:

- It provides guidance to the types of phenomena to look for when the demonstration and test fuels are examined.

- It provides a basis to project fuel assembly behavior to conditions beyond test and demonstration conditions.

- It gives insights to the most probable failure mechanisms and modes of failure, providing a basis to scope demonstration and test conditions to address failure mechanisms.

This section briefly reviews and augments prior assessments of Zircaloy-clad fuel behavior in dry storage. Prior publications have predicted fuel behavior in dry storage. $(12,17,37,39)$ The following potential cladding degradation mechanisms have been considered by Blackburn et al.: (39)

- rupture from mechanical overload

- stress rupture

- SCC from fission products

- rapid fracture of flawed cladding

- hydrogen-induced cracking

- internal hydriding

- cladding oxidation.

It was concluded that the maximum allowable temperature for Zircaloy-clad fuel in dry storage is $\sim 380^{\circ} \mathrm{C}$, based on stress rupture considerations. However, uncertainties in the possible role of SCC was acknowledged. (39) Experiments to confirm the predictions were directed to temperatures from 480 to $570^{\circ} \mathrm{C}$. (17) No ruptures occurred on irradiated PWR rods; however, test times at temperature caused annealing of radiation effects, resulting in improved ductility when compared with as-irradiated properties. Additional PWR whole-rod experiments 
are under way at $B C L$ at $325^{\circ} \mathrm{C}$ to investigate rod behavior with residual irradiation. Rod behavior under dry storage conditions is also being investigated in the Federal Republic of Germany. $(9,12,37)$

Dry storage assessments by FRG investigators are directed to inert cover gases. The following points have been emphasized: $(12,37)$

- Oxidation and hydriding due to cover gas impurities are not significant.

- No significant additional fission product release is expected from the fuel, which tends to minimize the prospects for fission product attack on the cladding interior. Fission products released during reactor operation will tend to react with the cladding or with other species inside the fuel rod during reactor residence.

- Calculations suggest that crack propagation is not likely in Zircaloy cladding for cracks smaller than $300 \mu \mathrm{m}$ at temperatures be low $450^{\circ} \mathrm{C}$. Larger cracks have not been observed in postirradiation examination (PIE) of German fuel.

- Hoop strain limits dry storage temperatures for Zircaloy to $\sim 400^{\circ} \mathrm{C}$, if the total strain is limited to 1 uniform elongation.

Effects of cladding creep, crack propagation, uniform and local corrosion, hydrogen interaction and diffusion, and gas-side oxidation have been factored into experimental programs conducted by FRG investigators. The experimental verifications currently under way include: demonstrations with 2 PWR and 16 BWR assemblies; whole rod tests ( 9 PWR and 14 BWR); iodine SCC studies using cladding from various suppliers and a range of iodine concentrations and helium fill gas pressures; postirradiation creep studies on cladding samples preirradiated and stored at $400^{\circ} \mathrm{C}$ with an internal helium pressure of 45 bars (at room temperature).

In this report, aspects of the prior theoretical assessments are discussed, and additional topics are addressed. The following topics will be assessed from the standpoint of fuel performance in dry storage: 
- cover gas characteristics

- fuel oxidation

- cladding oxidation under normal and abnormal conditions

- decay heat characteristics of spent fue 1

- annealing of radiation damage

- strain rate effects

- reactor and storage regimes

- Zircaloy SCC

- creep and stress rupture properties

- hydrogen effects in Zircaloy cladding

- characteristics of fuel crud and its potential impact on dry storage

- temperature-time characteristics of Zircaloy-clad fuel

- dry storage of SS-clad LWR fuel.

\section{COVER GAS CHARACTERISTICS}

Dry storage demonstrations have involved the cover gases $s^{t}$ wn in Table 9, which include air, argon, carbon dioxide, helium, and nitrogen. Table 13 compares properties and costs for candidate cover gases and for water vapor.

TABLE 13. Costs and Properties of Candidate Cover Gases and Water Vapor

\begin{tabular}{|c|c|c|c|c|c|c|}
\hline \multirow[b]{2}{*}{ Gas } & \multirow{2}{*}{$\begin{array}{l}\text { Purity } \\
\%(a) \\
\end{array}$} & \multirow{2}{*}{$\begin{array}{c}\text { Cost, } \\
\$ / 1000 \mathrm{ft}^{3(\mathrm{~b})} \\
\end{array}$} & \multicolumn{2}{|c|}{$\begin{array}{c}\text { Heat Capacity, (c) } \\
\text { J/mole K }\end{array}$} & \multicolumn{2}{|c|}{$\begin{array}{l}\text { Thermal } \\
\text { Conductivity (c) } \\
\times 10^{-3}, \mathrm{~J} / \mathrm{s}-\mathrm{cm} \mathrm{K}\end{array}$} \\
\hline & & & $300 \mathrm{~K}$ & $700 \mathrm{~K}$ & $300 \mathrm{~K}$ & $700 \mathrm{~K}$ \\
\hline Air (dry) & -- & - & 29.1 & 31.1 & 0.262 & 0.524 \\
\hline Argon & 99.995 & 231 & 20.8 & 20.8 & 0.177 & 0.338 \\
\hline Carbon dioxide & $99.99(d)$ & 104 & 37.2 & 49.6 & 0.166 & $0.431^{(e)}$ \\
\hline Helium & 99.995 & 345 & 20.8 & 20.8 & 1.50 & 2.78 \\
\hline Nitrogen & 99.998 & 94 & 29.0 & 29.5 & 0.259 & 0.498 \\
\hline Water vapor & -- & - & -- & 36.8 & 0.181 & 0.572 \\
\hline
\end{tabular}

\footnotetext{
(a) Wide range of purities and prices available (99.9999\% to $99.5 \%$ ).

(b) Single cylinder prices as of June 1982;1 $\mathrm{m}^{3}=35 \mathrm{ft}^{3}$.

(c) At 1 atm.

(d) $\mathrm{CO}_{2}$ purity is $>99.8 \%$ at Wylfa.

(e) At $600 \mathrm{~K}$.
} 
The major criteria for cover gas selection are:

- compatibility with fuel cladding and storage system components: Inert gases have traces of impurities $\left(\mathrm{H}_{2} \mathrm{O}, \mathrm{H}_{2}, \mathrm{CO}, \mathrm{CO}_{2}\right.$, etc). Current technology permits purification to $\sim 1 \mathrm{vppm}$. Much higher impurity levels are tolerable for fuel cladding or system materials in dry storage; commercial gases have higher impurity levels (Table 13). Residual moisture levels after metal casks or canisters are loaded with fuel in water pools remain to be defined but will probably exceed levels indigenous to the gases even with cask drying operations. For more reactive cover gases, interactions with exposed $\mathrm{UO}_{2}$ will be a significant consideration.

- heat transfer: Helium has the highest thermal conductivity (see Table 13). For older fuel, cover gases with lower thermal conductivit ies may be satisfactory.

- monitorability: Decisions regarding cover gas monitoring levels and approaches have not been established for dry storage in the United States. The current approach for metal cask cover gas monitoring in the Federal Republic of Germany involves 1-atm helium in contact with the fuel and 6-atm nitrogen in the space between the first and second 1ids. Nitrogen leakage into the helium chamber would be detected by a decrease in the nitrogen pressure between the first and second lids. Cover gas monitoring may not be necessary for fuel stored below temperatures where fuel oxidation is significant.

- leakage: For dry storage components with welded closures (casks and canisters), cover gas losses by leakage will be negligible. For vaults, leakage losses may not be negligible. Helium is somewhat more prone to leakage than heavier gases; however, helium is used as a cover gas in large nuclear systems such as high-temperature gas reactors (HTGRs), where leakage is significant but tolerable. Argon is used as a cover gas in both the north (main cell) and south (argon cel1) vaults at the HFEF in Idaho. $(3,50)$ The vault volumes are 1500 and $1900 \mathrm{~m}^{3}$, respectively. 
The HFEF cells are constructed to minimize inleakage:

- The facility liners are welded stainless steel.

- All penetrations have double seals.

- Seals are purged with argon.

The measured rate of air inleakage to the $\mathrm{HFEF} / \mathrm{N}$ argon cell at startup was $0.02 \mathrm{ft}^{3} / \mathrm{min}\left(\sim 6 \times 10^{-4} \mathrm{~m}^{3} / \mathrm{min}\right)$.

Argon cover gas monitoring at HFEF involves analysis of gas samples drawn periodically from the system for $\mathrm{O}_{2}$ and $\mathrm{H}_{2} \mathrm{O}$. The specifications are $60 \pm 40 \mathrm{vppm}$ each for $\mathrm{O}_{2}$ and $\mathrm{H}_{2} \mathrm{O}$. Cover gas purification involves an automatic feed and bleed system that passes gas through a palladium catalyst to convert $\mathrm{H}_{2}$ and $\mathrm{O}_{2}$ to $\mathrm{H}_{2} \mathrm{O}$, followed by passage through a $\mathrm{gas}$ dryer. The argon used at HFEF is high-purity grade with the following specifications: moisture, $4.6 \mathrm{~g} / \mathrm{m}^{3}$ (2 grains $/ 1000 \mathrm{ft}^{3}$ ); $10-\mathrm{vppm} 0_{2}, 20-\mathrm{vppm} \mathrm{N} \mathrm{N}_{2}, 5$-vppm carbon-bearing gases, and 1-vppm $\mathrm{H}_{2}$.

Table 13 provides cost data for candidate cover gases. For the cask shown in Figure $5 b$ (see p. 12), the free volume (total volume minus fuel assembly volume) is $7.7 \mathrm{~m}^{3}\left(\sim 270 \mathrm{ft}^{3}\right)$. Cover gas costs for a PWR discharge (assuming three casks per discharge) are a negligible fraction of storage costs, regard less of the purity level. Use of higher purity levels is not justified, particularly for cases where casks or canisters are loaded underwater. (a)

For vault use where large gas volumes are required, unit costs $\left(\$ / 1000 \mathrm{ft}^{3}\right)$ may be substantially lower than those shown in Table 13. For example, gas purchases of $\sim 100,000 \mathrm{ft}^{3}$ /month result in a cost reduction by a factor of ten.

(a) The significance of cover gas impurities is illustrated by the following example: The surface area of all Zircaloy rods in the cask in Figure 5b is $\sim 53,000 \mathrm{dm}^{2}$; 1 vppm of $\mathrm{H}_{2} \mathrm{O}$ in the cover gas represents $\sim 6 \mathrm{mg}$, corresponding to $\sim 10^{-4} \mathrm{mg} / \mathrm{dm}^{2}$ of oxide formation on the Zircaloy if all the $\mathrm{H}_{2} \mathrm{O}$ reacts. Thus, the impurity leve 1 in the closed cask could reach $\sim 10^{4} \mathrm{vppm}$ before the corresponding Zircaloy oxidation would become significant. 
Stainless steel and nickel-plated cask component interactions with impurities will be negligible compared to Zircaloy because reaction rates are lower than for Zircaloy.

FUEL OXIDATION

For Zircaloy-clad fuel in a dry storage oxidizing environment, oxidation of $\mathrm{UO}_{2}$ exposed at cladding defects is a principal consideration. If the cladding defect developed in the reactor, several cases are possible:

- The defect may be a pinhole or narrow crack and may be almost resealed or have a sufficiently small aperture to largely inhibit air ingress.

- The defect may expose a small $\mathrm{UO}_{2}$ area, with relatively little washout or fuel oxidation.

- The defect may be a circular or elongated hole, with possible substantial fuel washout.

- The defect may be a longitudinal split, probably propagated by in-reactor fuel oxidation and hydriding if the cladding is Zircaloy; some fuel washout and conversion of $\mathrm{UO}_{2}$ to higher oxides may result.

This section reviews basic thermodynamics and kinetics of uranium oxide oxidation and some results for defected Zircaloy-clad fuel rods. The effectiveness of the cladding to protect fuel from oxidation is a key aspect of fuel behavior in dry storage. If inert cover gases are used, fuel oxidation will be precluded; however, some U.S. utilities are interested in establishing the maximum temperatures that are satisfactory for dry storage of Zircaloyclad fuel in air. As with cladding oxidation, predictions of fuel oxidation must be scoped to declining fuel temperatures.

The most 1 imiting problem associated with storing spent LWR fuel in air is the tendency for $\mathrm{UO}_{2}$ to react with oxygen and transform into higher oxidation states. The Zircaloy cladding will protect the fuel from oxidation 
if it is leak proof; however, through-wall defects have been generated in up to $1 \%$ of the fue 1 rods during irradiation. (51) Because these defected fue 1 rods are not completely identifiable, some may enter storage. 0xygen ingress $\mathrm{c}$ an lead to the oxidation of $\mathrm{UO}_{2}$ to form higher oxide forms of $\mathrm{U}_{3} \mathrm{O}_{8}$ and $\mathrm{UO}_{3}$ at expected storage temperatures (see Figure 11). (53) Consequently, the formation of the low-density $\mathrm{U}_{3} \mathrm{O}_{8}$ product causes a marked volume expansion that can generate stresses and propagate defects in the thin-walled cladding. (52) Higher oxide forms of $\mathrm{U}_{3} \mathrm{O}_{8}$ and $\mathrm{UO}_{3}$ may form at expected storage temperatures (see Figure 11). (53) The extent of the formation depends on the kinetics of oxygen ingress through cladding defects and diffusion into the fuel pellets. This section reviews $\mathrm{UO}_{2}$ oxidation in terms of its applicability to storage of spent fuel in air environments.

\section{Temperature Effects}

Some uranium oxide forms higher than $\mathrm{UO}_{2}$ are more stable and may form from $\mathrm{UO}_{2}$ in various oxidizing atmospheres. Even at room temperature ${ }^{(54)}$ and at temperatures as $10 \mathrm{w}$ as $-183^{\circ} \mathrm{C}$, oxygen is chemisorbed on the $\mathrm{UO}_{2}$ surface and $\mathrm{c}$ an form an amorphous layer of $\mathrm{UO}_{3}$. For anticipated storage temperatures between 100 and $250^{\circ} \mathrm{C}, \cup \mathrm{O}_{2}$ will initially be oxidized to a tetragonal form, $\mathrm{U}_{3} \mathrm{O}_{7+\mathrm{x}} \underset{(57,58)}{(55,56)}$ At $\sim 100$ to $300^{\circ} \mathrm{C}$, the tetragonal $\mathrm{U}_{3} \mathrm{O}_{7}$ forms to a depth of 3 to $10 \mathrm{\mu m}$. it is not considered to be a bulk phase and is not shown on Figure 11 . The tetragonal $\mathrm{U}_{3} \mathrm{O}_{7}$ form has a higher density $(11.4 \mathrm{~g} / \mathrm{cc})$ than the alpha cubic form of $\mathrm{UO}_{2}(10.97 \mathrm{~g} / \mathrm{cc})$ and, therefore, is not damaging with respect to fue 1 swelling and cladding interactions. Further oxidation through the $\mathrm{U}_{3} \mathrm{O}_{7}$ layer increases the $0 / U$ ratio of the $U_{3} 0_{7}$ layer to as high as 2.4. (56)

Above $300^{\circ} \mathrm{C}$, the $\mathrm{UO}_{2}$ phase can rapidly transform to orthorhombic $\mathrm{U}_{3} \mathrm{O}_{8}$ before the formation of the $\mathrm{U}_{3} \mathrm{O}_{7}$ phase can be detected, except at $\mathrm{O}_{2}$ pressures below 0.01 to $0.1 \mathrm{~atm}$. The orthorhombic $\mathrm{U}_{3} \mathrm{O}_{8}$ structure has a much lower density than the $\mathrm{UO}_{2}\left(8.35 \mathrm{~g} / \mathrm{cc}\right.$ versus 10.97 for $\left.\mathrm{UO}_{2}\right)$, which leads to the volume expansion and causes spalling of the surface layer into a fine particulate powder during formation. A fresh surface is created on which a new layer of $\mathrm{U}_{3} \mathrm{O}_{7}$ may form. 


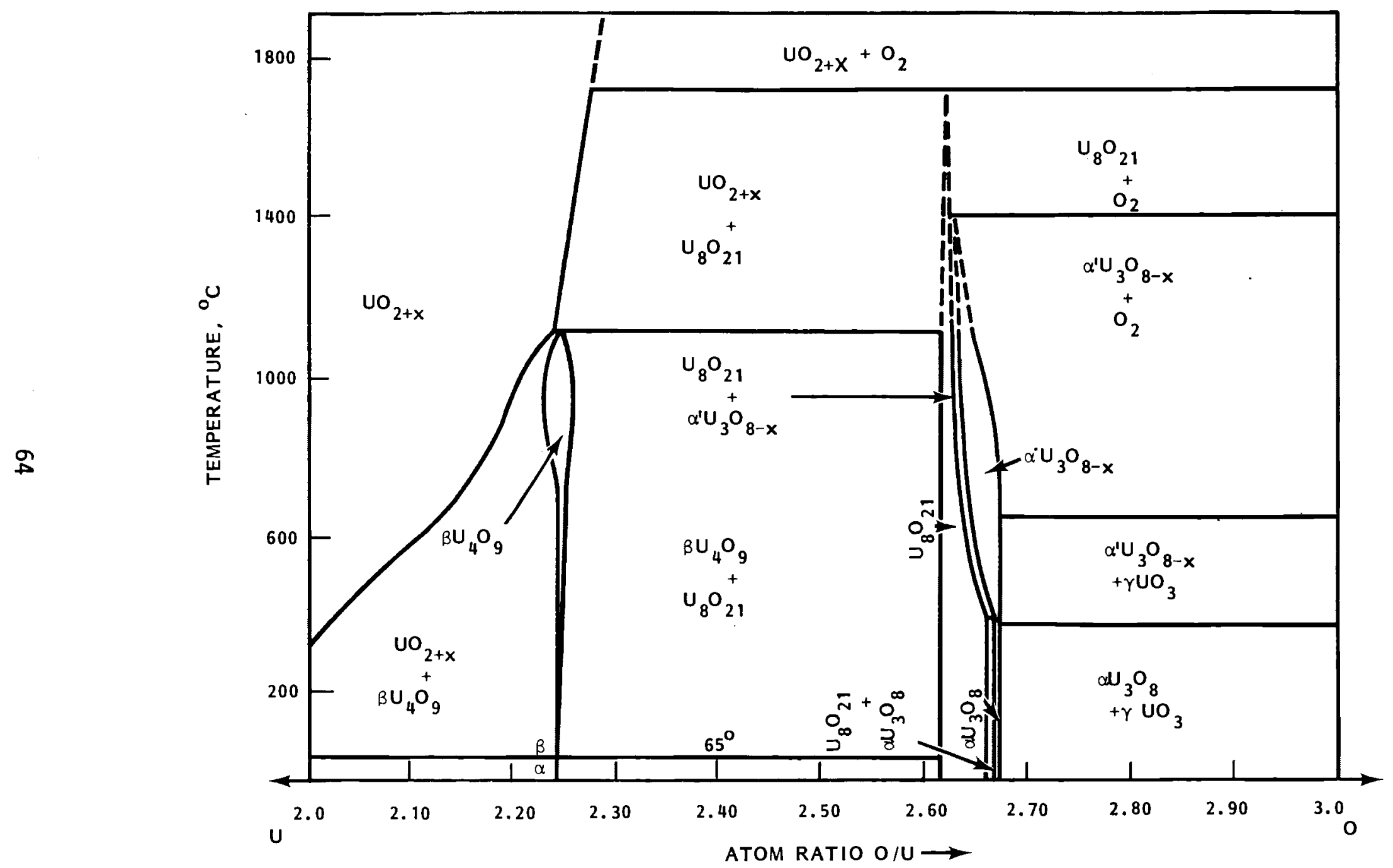

FIGURE 11. U-0 Phase Diagram 
This sequence of events leads to $\mathrm{U}_{3} \mathrm{O}_{8}$ formation through successive removal of layers through spalling. The particulate size of the $\mathrm{U}_{3} \mathrm{O}_{8}$ powder is regulated by the thickness of the $\mathrm{U}_{3} \mathrm{O}_{7}$ surf ace layer. The low density of the $\mathrm{U}_{3} \mathrm{O}_{8}$ powder leads to mechanical interaction between the fuel and cladding.

The time required for nucleation and growth of $\mathrm{U}_{3} \mathrm{O}_{8}$ is temperature dependent (see Figure 12). Whereas approximately $1 \mathrm{~h}$ is required to form $\mathrm{U}_{3} \mathrm{O}_{8}$ from powdered $\mathrm{UO}_{2}\left(<100\right.$ micron) at $300^{\circ} \mathrm{C}$, approximately $24 \mathrm{~h}$ is required at $260^{\circ} \mathrm{C} .{ }^{(44)}$ Some tests on oxidation of $\mathrm{UO}_{2}$ powder ( $<100$ micron) to $\mathrm{U}_{3} \mathrm{O}_{8}$ have shown nearly complete conversion in $500 \mathrm{~h}$ at $250^{\circ} \mathrm{C} .(40)$ Extrapolation of oxidation results for $\mathrm{UO}_{2}$ pellets ${ }^{(40)}$ to temperatures below the range of the data

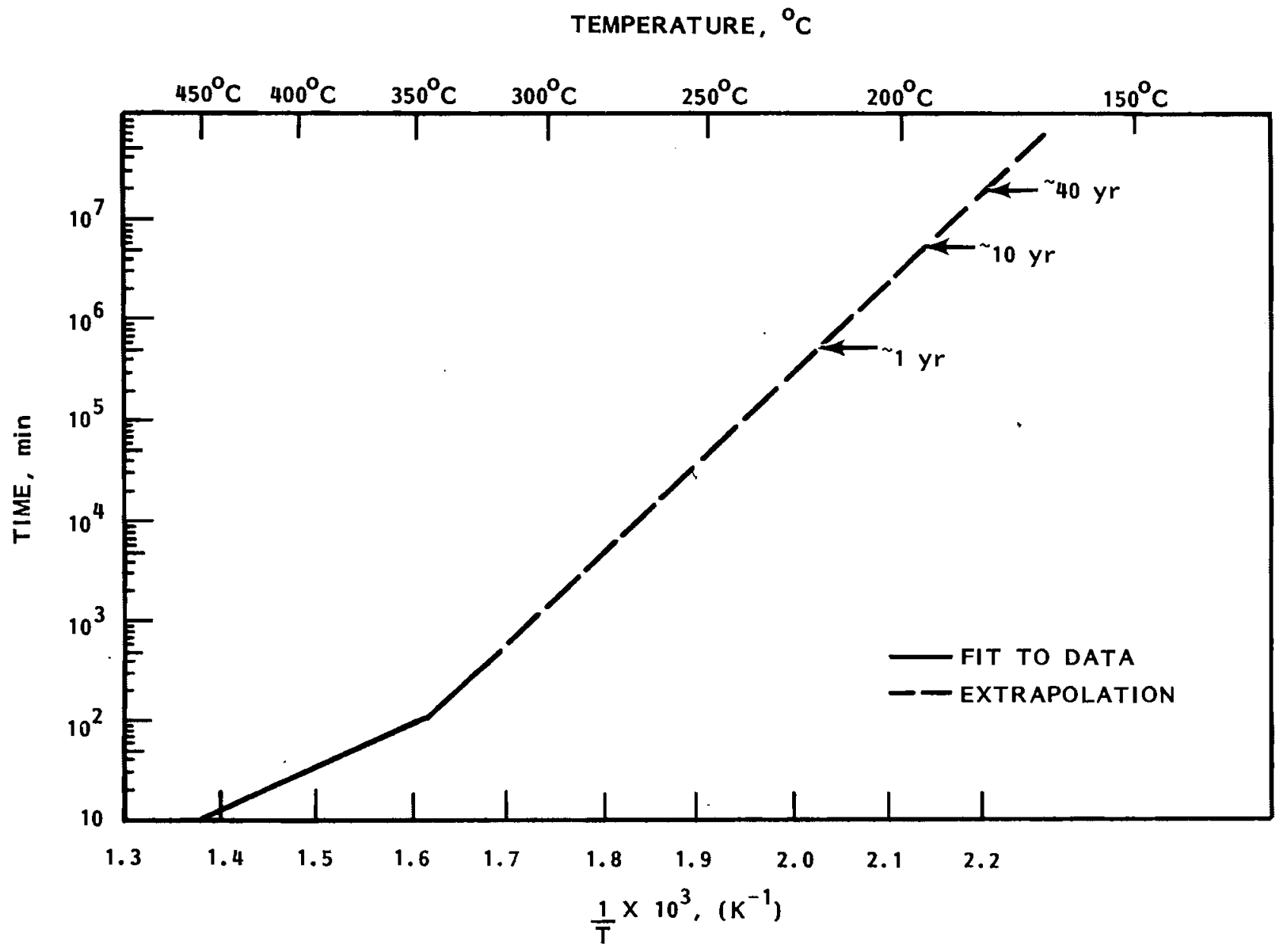

FIGURE 12. Time to Oxidize Unirradiated $\mathrm{UO}_{2}$ Pe 
base (Figure 12) and integration over a decreasing temperature ramp with time ${ }^{(a)}$ leads to predictions of $<30 \%$ oxidation of fuel to $\mathrm{U}_{3} \mathrm{O}_{8}$ if the starting storage temperature is $250^{\circ} \mathrm{C}$ and $<10 \%$ if the starting temperature is $230^{\circ} \mathrm{C}$.

Effect of $\mathrm{UO}_{2}$ Particle Size

At a constant temperature, the initial rate of $\mathrm{UO}_{2}$ oxidation to $\mathrm{U}_{3} \mathrm{O}_{7}$ is strongly dependent on the microstructure and the surface area. $\mathrm{UO}_{2}$ powders and fragmented pellets oxidize to $\mathrm{U}_{3} \mathrm{O}_{7}$ more rapidly than high-density pellets and single crystals. ${ }^{(59-62)}$ oxygen penetrates the $\mathrm{UO}_{2}$ through grain boundaries, cracks, and porosity to form $\mathrm{U}_{3} 0_{7}$; hence, the effective oxidation rate depends on the imperfections of the $\mathrm{UO}_{2}$ substrate.

Effects of Cover Gas Composition

Uranium oxide oxidation has shown very little sensitivity to the moisture content of the air. ${ }^{(60)}$ significant sensitivity was found, however, for the $\mathrm{NO}_{2}$ content of the reacting atmosphere. ${ }^{(63)} \mathrm{NO}_{x}$ gases are expected to form in the dry air atmosphere surrounding spent fuel due to the ionization the gas by radiation fields generated by the spent fuel.

The leak rate of the large $\mathrm{CO}_{2}$ molecules from the container is lower than the leak rate of helium or argon. The very low dissociation of $\mathrm{CO}_{2}$ results in a low concentration of free oxygen for reaction with $\mathrm{UO}_{2}$. Although metallic uranium reacts with $\mathrm{CO}_{2}$ between 350 and $650^{\circ} \mathrm{C}$ to form $\mathrm{UO}_{2}$ and $\mathrm{U}_{3} \mathrm{O}_{8},{ }^{(64)} \mathrm{UO}_{2}$ is expected to react much more slowly. $\mathrm{UO}_{2}$ reacts with $\mathrm{CO}_{2}$ during irradiation at temperatures as low as $66^{\circ} \mathrm{C}$ to form $U_{3} 0_{7}{ }^{\circ}(65)$ The enhanced oxidation is attributed to irradiation-enhanced diffusion of oxygen in $\mathrm{UO}_{2}$. Before considering storage of spent fuel in $\mathrm{CO}_{2}$ for protection from oxidation, the dissociation of $\mathrm{CO}_{2}$ under radiation fields encountered in spent fuel storage and the associated potential for oxidation should be determined.

(a) As shown in Figure 7 for a hypothetical decay curve to $40 \mathrm{yr}$ for $2-$ to 3-yr old fuel. 


\section{Radiation Effects}

Although most $\mathrm{UO}_{2}$ oxidation studies have been performed on unirradiated materials, at least two studies have incorporated irradiated samples. The first study involved $\mathrm{UO}_{2}$ spheres irradiated at an atypically low irradiation temperature of $400^{\circ} \mathrm{C}$ and to a low burnup range of 1 to $9 \%$ (57) The mild conditions enabled the $\mathrm{UO}_{2}$ to survive irradiation with little structural damage. Oxidation rates at 320 and $380^{\circ} \mathrm{C}$ after irradiation were initially higher than for unirradiated $\mathrm{UO}_{2}$ spheres; however, the peak rate was suppressed by irradiation. The decrease in peak rate was attributed to effects of fission product chemistry, i.e., competition by fission products for available oxygen. This position is contrary to others that have speculated that fission products will not compete for oxygen since uranium has a higher affinity for oxygen than the fission products. ${ }^{(66)}$

The second study on the oxidation of irradiated $\mathrm{UO}_{2}$ was conducted with CANDU Pickering fue 1 rods irradiated to a burnup of $197 \mathrm{MWh} / \mathrm{kgU}(0.8 \%$ burnup). (52) The study was conducted on artificially defected viole rods, extracted fuel pellets (cracked during irradiation), and powdered material prepared by ball milling pellet fragments. No irradiation effect was found for the pellet fragments between 350 to $420^{\circ} \mathrm{C}$ in air. Long-term exposures at lower temperatures were not conducted. The irradiated powder was oxidized in air at temperatures between 210 and $294^{\circ} \mathrm{C}$. Irradiation enhanced the oxidation rate to $\mathrm{U}_{3} \mathrm{O}_{8}$ powder and significantly accelerated the initial stages of the reaction, suggesting a much larger exposed surface area for oxidation. It was suggested that increased porosity may have been produced by opening fission gas bubbles when the irradiated material was ball milled. The irradiated defected fuel rods displayed higher rates of oxidation. The cladding developed secondary swelled areas away from the initial defect due to oxygen transport along cracks in the irradiated fuel pellets. Apparently the effects of the increased surface area from porosity and crack formation were greater than the competition between $\mathrm{UO}_{2}$ and fission products for oxygen. 


\section{Fission Product Release}

As $\mathrm{U}_{3} \mathrm{O}_{8}$ particulate matter forms, significant fractions of the fission products previously entrained within the $\mathrm{UO}_{2}$ matrix are released. ${ }^{(66)}$ The release is associated with the large surface area created by the formation of the particulate $\mathrm{U}_{3} \mathrm{O}_{8}$.

\section{CLADDING OXIDATION}

Cladding oxidation is assessed for two dry storage regimes: normal storage and abnormal events. The assessments include 1 imited and unlimited oxidant and isothermal and nonisothermal fuel cladding temperatures.

Zircaloy cladding oxidation involves two regimes: pretransition, where a black, highly protective oxide $\left(\mathrm{Zr}_{1.95}\right)$ forms under parabolic or cubic kinetics; and post-transition, which involves oxide formation under linear kinetics, with less protective oxides that progress from black to mottled gray to beige or white. Equations to describe the two oxidation regimes have been published by Hillner. $(67)$

Normal dry storage involves fuel assemblies emplaced at or below a maximum temperature, followed by declining temperatures (see figure 7). FRG investigators project a temperature decay curve that begins at $400^{\circ} \mathrm{C}$ (fuel cooled $\sim 1 \mathrm{yr}$ ), declines to $300^{\circ} \mathrm{C}$ after $1 \mathrm{yr}$ in dry storage, $200^{\circ} \mathrm{C}$ after $\sim 2 \mathrm{yr}$ in dry storage, and 70 to $80^{\circ} \mathrm{C}$ after $20 \mathrm{yr}$ in dry storage. ${ }^{(37)} \mathrm{Cladding}$ oxidation will proceed at declining rates that correspond to the declining temperatures.

It is beyond the scope of this report to examine in detail the credibilities of specific abnormal events in dry storage. The events will vary with storage system design and local factors. Abnormal factors have been reviewed for dry well, vault, and silo facilities. ${ }^{(3)}$ Metal casks have been tested for fires, crashes, and drops that might occur during cask transportation.

Limited oxidant can exist in storage facilities from the following sources: 
- trace impurities in inert gases, which result in inconsequential oxidation for normal impurity levels (see Cover Gas Characteristics section)

- residual moisture from in-pool fuel loading and/or water-logged defective fuel; although typical levels in actual operations remain to be defined, it is not likely that residual moisture will be a substantial source of cladding oxidation

- slow inleakage to a dry storage chamber (for example, a vault); if the fuel is canned, inleakage will not influence the fuel cladding; events that result in inleakage to sealed canisters or metal storage casks appear to be highly unlikely.

- the inventory of oxidant if an oxidizing cover gas (for example, air) is used; if oxidation conditions eventually deplete the oxidant sealed in the dry storage chamber, then the logic of using an oxidizing cover gas depends on whether the oxidant has undesirable impacts and whether the decrease in cover gas pressure is tolerable if the oxidant reacts with materials in the storage system (frequently the storage system pressure is intentionally subatmospheric to assure inleakage if a leak occurs). However, if oxidation is expected to deplete the oxidant (for example, $\mathrm{O}_{2}$ in air), it may be more logical to begin with only the residual gas $\left(N_{2}\right.$ in the case of air). Some facilities now in operation (see Table 9) use air for the cover gas. The volumes (for example, $1500 \mathrm{~m}^{3}$ at HFEF/N) may border on unlimited air from the standpoint of oxidation. If the fuel is canned, the vault cover gas will be isolated from the fuel cladding. For metal cask storage, the thick metal structure is competely sealed. Nodular cast iron casks have survived fires, drops, and impacts simulating an aircraft crash, suggesting that a cask breach that leads to unlimited air during storage is highly unlikely. Nonetheless, oxidation in unlimited air is assessed below for Zircaloy-clad fuel. 
Experience from dry storage demonstrations indicates that temperature gradients exist in LWR fuel assemblies. Axial temperature gradients exist, $(38,18)$ and center rods in an assembly will be hotter than peripheral rods. (18) Initial rod temperatures for KWW (BWR) assemblies varied from 180 to $\sim 385^{\circ} \mathrm{C}$, but only $\sim 20$ rods near the center of the assemblies were at the highest temperature. ${ }^{(9)}$

Oxidation Under Normal Dry Storage Conditions

The oxygen inventory in air sealed in a cask of the type shown in Figure $5 \mathrm{~b}$ is sufficient to oxidize all $\mathrm{UO}_{2}$ in $\sim 20$ PWR rods if 1 ) cladding defects permit access to the fuel pellets and 2) the temperature is high enough to promote $\mathrm{UO}_{2}$ oxidation. Alternatively, if the oxygen inventory were to deposit on the Zircaloy fuel rods, the amount of oxide would be $\sim 40 \mathrm{mg} / \mathrm{dm}^{2}(\sim 3 \mu \mathrm{m})$. This mild degree of oxidation would occur only if the temperatures were uniform and sufficiently high. If temperature gradients caused oxide deposition on only $10 \%$ of the fue 1 rod area, the oxide thickness would be $\sim 30 \mu \mathrm{m}(-0.0012 \mathrm{in.})$, which represents only about 5 of the cladding thickness of PWR rod. These calculations assume the bounding case of complete oxygen uptake by the Zircaloy without regard for mitigating effects of decreasing temperatures and oxygen pressures.

Figure 13 provides a basis to assess the extent of oxidation on Zircaloy in various normal and abnormal dry storage situations. It is important to recognize that reactor-formed oxides on Zircaloy cladding will always be in the post-transition range at the end of a nomal reactor 1 ife (see Appendix $\mathrm{C}$ ). The curves in Figure 13 are constructed assuming $\sim 150 \mathrm{mg} / \mathrm{dm}^{2}(\sim 10 \mu \mathrm{m})$ of oxide, which is clearly in the post-transition range.

For an initial temperature of $400^{\circ} \mathrm{C}$ and decreasing temperatures, ${ }^{(37)}$ the total oxide thickness until the temperature drops below $250^{\circ} \mathrm{C}$ (where Zircaloy oxidation rates are inconsequential) would be $77 \mathrm{mg} / \mathrm{dm}^{2}(\sim 5 \mu \mathrm{m})$ if the oxidant supply is sufficient. Dry storage is assumed to begin $\sim 1$ yr after the fuel is discharged, and it is assumed that the temperature drops below $200^{\circ} \mathrm{C} \sim 3 \mathrm{yr}$ after discharge. For a starting temperature of $250^{\circ} \mathrm{C}$, the incremental Zircaloy cladding oxidation would be $<4 \mathrm{mg} / \mathrm{dm}^{2}(0.3 \mu \mathrm{m})$ even if the temperature remained at $250^{\circ} \mathrm{C}$ for $40 \mathrm{yr}$. 


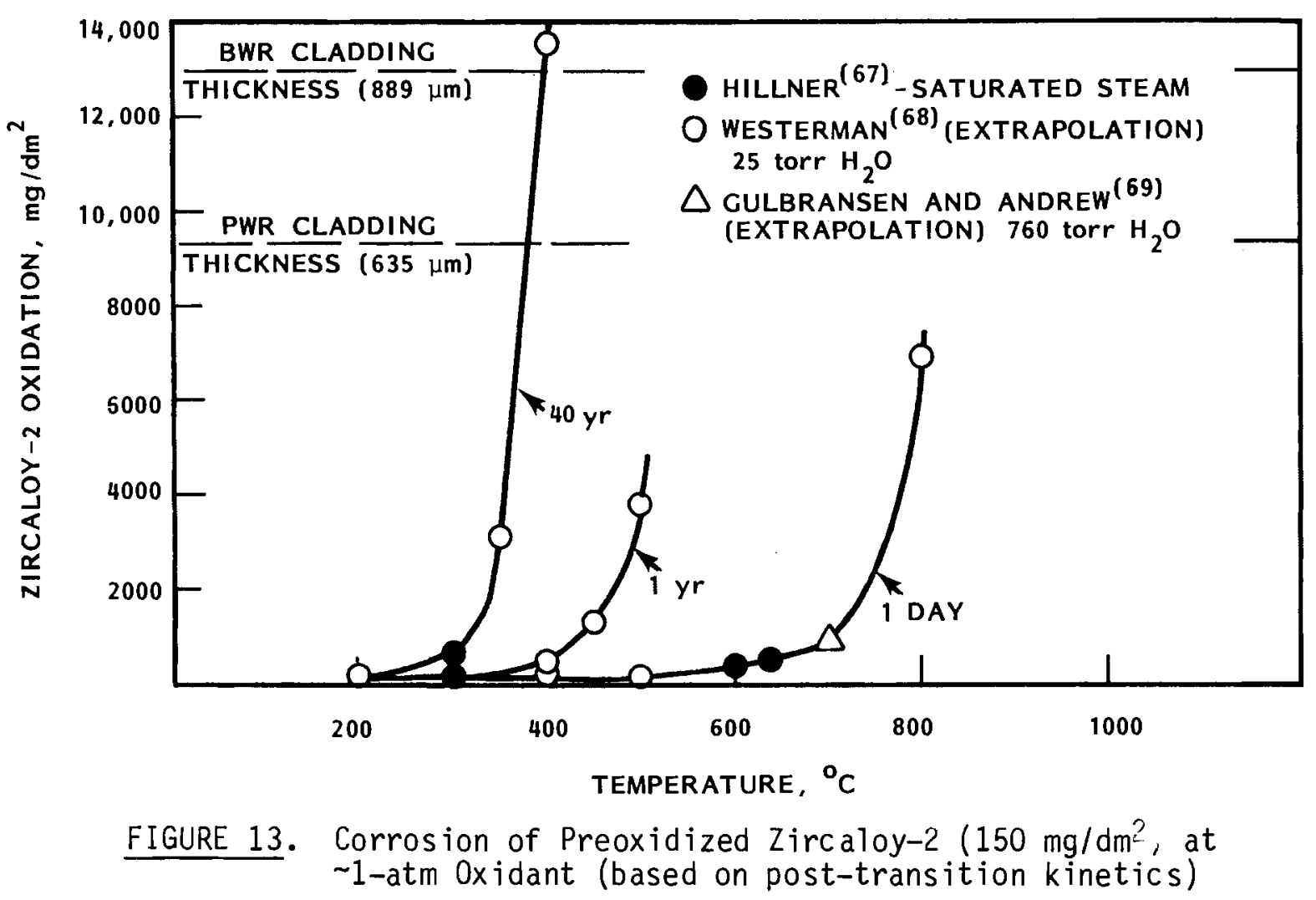

Thus, oxidation is not a threat to Zircaloy cladding integrity for nomal dry storage. For oxidizing cover gases, the prinaipal integrity consideration is then: What is the maximum acceptable temperature to preclude significant oxidation of $\mathrm{UO}_{2}$ if it is exposed at cladding defects?

Oxidation Under Abnormal Dry Storage Conditions

The credibility of abnomal events for licensed dry storage remains to be assessed; therefore, it is premature to address specific cases. 0xide formation as a function of temperature for heating times of $1 \mathrm{yr}$ and 1 day are shown in Figure 13. $(68,69)$ For limited air, the maximum degree of oxide formation was indicated in the previous section for cases where the temperature is sufficiently high for all the oxidant to react. For unlimited air, PWR cladding would fully oxidize in 1 day at $\sim 1100^{\circ} \mathrm{C}$ (off-scale on Figure 12); cladding rupture would occur sooner. At intermediate temperatures, PWR cladding would fully oxidize in $1 \mathrm{yr}$ at $\sim 570^{\circ} \mathrm{C}$.

Fuel Rod Behavior During Temperature Excursions

In assessing Zircaloy fue 1 rod behavior during temperature excursions there are several important considerations: 
- BWR and PWR fuel rods have different cladding thicknesses, rod diameters, and fill gas pressures.

- Axial temperature gradients exist in dry storage facilities. $(37,18)$

- Rapid annealing of radiation damage occurs at elevated temperatures, suggesting that tests with unirradiated rods are useful.

- Temperature distribution and rod-to-rod interactions play important roles in rod burst pressures, $(70,71)$ which suggests that test results from single rods may differ from results on rods in assemblies.

- In slow heatups, rod failure (if credible) may be influenced by the gas environment (inert or oxidizing) but only after relatively long times at elevated temperatures if oxidation is a factor (see Figure 13).

Spent fuel shipping casks are designed to withstand an $800^{\circ} \mathrm{C}$ fire for at least 30 min. (72) Several tests have been conducted that provide information on the behavior of Zircaloy-clad fuel rods during temperature excursions. Elevated temperature tests have been conducted on Zircaloy-clad fuel and include:

- heating at rapid rates $\left(28^{\circ} \mathrm{C} / \mathrm{s}\right)$ to simulate in-reactor 10ss-ofcoolant accidents (LOCAs) $(73,74)$

- heating at rates $\left(6^{\circ} \mathrm{C} / \mathrm{min}\right)$ to simulate oxidation phenomena in the Three Mile Island-2 accident ${ }^{(75)}$

- heating at relatively slow rates $\left(\sim 5^{\circ} \mathrm{C} / \mathrm{s}\right)$ to simulate Zircaloy fuel rod behavior in shipping cask fires (work in progress)

- isothermal heating at 480 to $570^{\circ} \mathrm{C}$. (17)

Recent tests were conducted by PNL in the National Research Universal (NRU) reactor, Chalk River, Canada. The tests provided mechanical deformation data for typical PWR fuel rods that are subjected to rapid temperature increases to simulate in-reactor LOCAs.

Published data $(70,71)$ indicate that PWR rods prepressurized to 465 psia (31 atm) failed at $\sim 870^{\circ} \mathrm{C}$ within $\sim 1$ min after the start of the transient. In 
this time span, oxidation is not significant to the cladding rupture. Prepressurization to $569 \mathrm{psia}(38 \mathrm{~atm})$ promoted failure at $\sim 802^{\circ} \mathrm{C}$ within $\sim 2 \mathrm{~min}$. The cladding temperature profiles increased from $-130^{\circ} \mathrm{C}$ at the lower end of the rod to peak temperatures near the center of the rods. Plenum temperatures were near peak cladding temperatures. Thus, the effective gas temperatures prior to failure were lower than the failure temperatures reported above. These tests suggest that prepressurized PWR spent fuel rods would fail rapidly if temperatures during a rapid heatup approached $800^{\circ} \mathrm{C}$.

The temperature profile generated in the NRU tests is steeper and has potentially more severe consequences than a uniform temperature over the length of the fuel rod. In an abnormal cask event, substantial temperature elevations require several hours. For example, for a $30-$ min torch fire $\left(1200^{\circ} \mathrm{C}\right.$ flame temperature), the inner cask temperature reached a maximum after 160 to 380 min during four trials under varying conditions. (74) The maximum cask interior temperature was $\sim 100^{\circ} \mathrm{C}$ above the preexisting interior temperature. The cask heatup tests suggest that the fuel would not reach the range where cladding ruptures have occurred in the tests cited above $\left(\sim 760\right.$ to $\left.900^{\circ} \mathrm{C}\right)$.

Computer calculations were performed at PNL using the methods described in Reference 71 that suggested that a PWR rod pressurized to 441 psia (30 atm) and evenly exposed to a rapid temperature transient to $800^{\circ} \mathrm{C}$ would not fail within the short time frame of the NRU tests. As shown in Figure 14, the rod would uniformly strain $7 \%$ to decrease gas pressures and cladding stresses. Because the fuel rod would balloon over the entire length, the internal gas pressure would decrease sufficiently to limit cladding strains. However, if only $46 \mathrm{~cm}$ of the same rod were heated to $800^{\circ} \mathrm{C}$ while the remainder of the rod was maintained at $21^{\circ} \mathrm{C}$, then the fuel rod would fail within 2 min. Thus, the length over which the rod is heated can significantly affect both rod pressure and the yield stress of the cladding.

The extent of damage to fuel rods in a shipping cask fire would depend on how the fire interacts with the cask, the temperature profile along the fuel rod, the rate at which the cask and fuel rods are heated, and the speed of corrective action. Fuel rod interactions in an assembly may provide constraint 


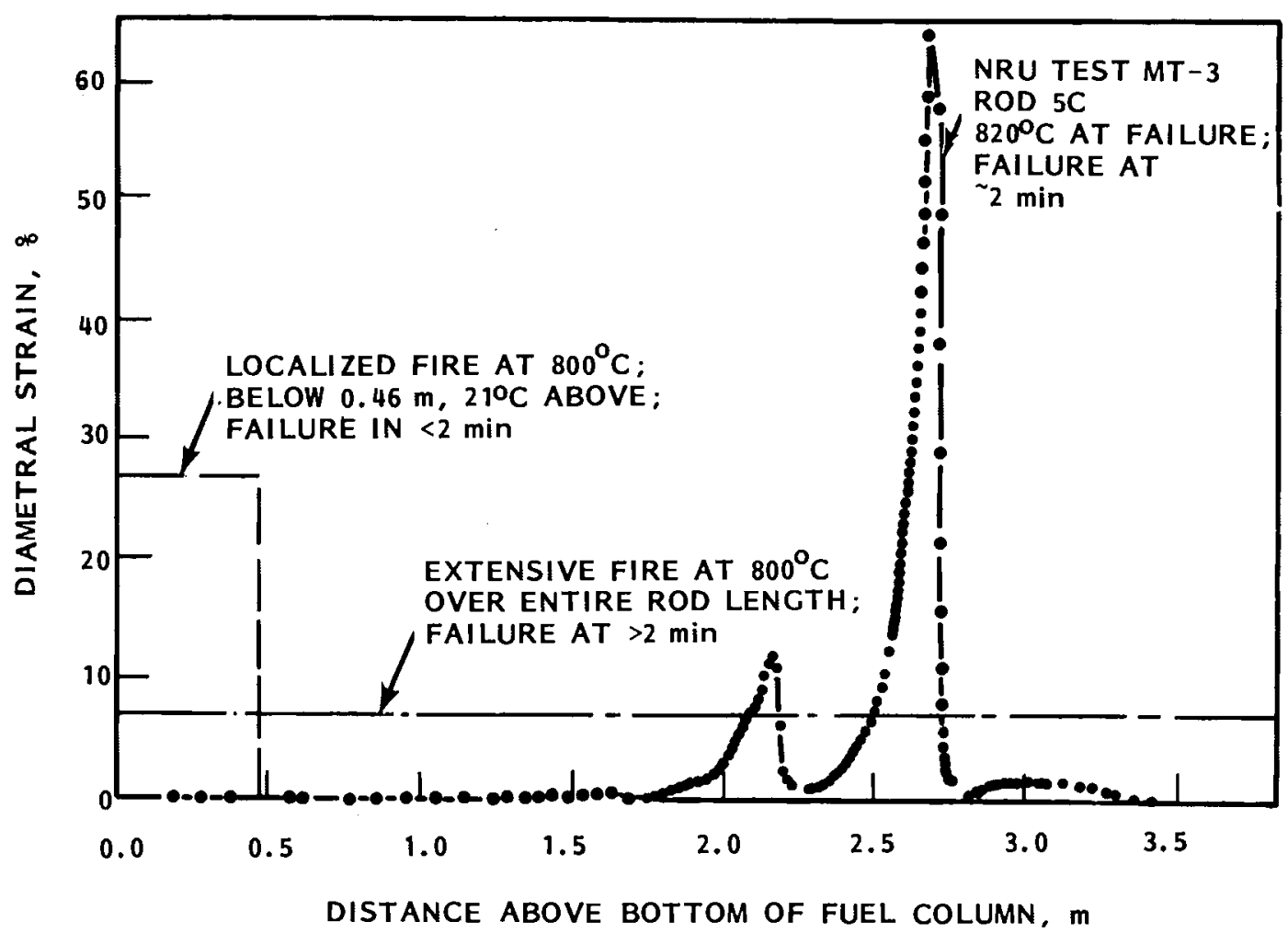

FIGURE 14. Comparison of Deformation of a PWR Fuel Rod That Failed in NRU Experiment MT-3 with Predicted Deformation for PWR Rods

to extend the rupture life beyond predictions from single-rod behavior. Adequate modeling of storage casks for postulated temperature excursions requires specific information regarding these variables.

Work sponsored by DOE through the Sandia Laboratories is being conducted at $B C L$ to investigate Zircaloy-clad fuel behavior in cases where a metal shipping cask is exposed to a major fire. That information may be relevant to abnormal storage cask events. K. KoK of $B C L$ indicated the following test conditions and results for the $B C L$ elevated temperature tests:

- 30-cm (12-in.) sections of irradiated PWR fuel rods are heated with fuel pellets in place.

- Heating is in flowing air at $\sim 5^{\circ} \mathrm{C} / \mathrm{min}$. 
- Fuel rods are prepressurized to $\sim 35$ atm at room temperature.

- The lower bound for rod rupture is 760 to $790^{\circ} \mathrm{C}\left(1400\right.$ to $\left.1450^{\circ} \mathrm{F}\right)$.

In the slow ramp tests, the rods ruptured at slight ly lower temperatures than in the rapid ramp (LOCA) tests. It is not clear whether the difference represents differences in fuel rod properties or whether it is related to ramp rate. There is other evidence, however, that Zircaloy rods tend to rupture at lower hoop stresses as the temperature ramp rate increases. (76)

Other experiments on whole rods heated in helium and 1 imited air demonstrated that extended exposure of prepressurized PWR rods at 480 to $570^{\circ} \mathrm{C}$ results in ballooning of the Zircaloy, but no rupture occurred in 6 months. Oxidation, however, was minimal. In unlimited air at $570^{\circ} \mathrm{C}$ for 6 months, oxide formation would have penetrated the cladding by $0.013 \mathrm{in} .(325 \mu \mathrm{m})$, which is approximately one-half of the PWR cladding thickness.

\section{DECAY HEAT CHARACTERISTICS OF SPENT FUEL}

Estimates of the decay heat from typical PWR and BWR fuel assemblies are presented in Figure 15. The decay heats were estimated using an empirical equation from Reference 77 . The in-reactor residence time used in that equation was calculated for each burnup in Figure 15 by assuming cont inuous power operation at a linear heat rate (LHR) of $23 \mathrm{~kW} / \mathrm{m}(7 \mathrm{~kW} / \mathrm{ft})$ for typical PWR and BWR fuel rods and assemblies. (a) In general, for the same type of fuel assembly, the decay heat is greatest in the assembly with the highest discharge burnup and is significant for storage times less than 5 to $10 \mathrm{yr}$. After about $15 \mathrm{yr}$, the decay heats that result from different burnups become essentially equal for the given range in burnups. Fuel operated at a rod LHR slightly lower than $7 \mathrm{~kW} / \mathrm{ft}$ but at an equal burnup would have a lower decay heat for the first $15 \mathrm{yr}$ of storage; however, after $\sim 15 \mathrm{yr}$, the decay heat would be essentially equal to those presented in Figure 15 for times greater than $\sim 15 \mathrm{yr}$. The primary reasons for the lower decay heat in the BWR assemblies are lower fuel weight (Appendix C) and lower burnup.

(a) Fuel Assembly Design: PWR: 205 rods with $95 \% \mathrm{TD} \mathrm{U0}_{2}$ fuel (excludes 20 nonfueled rods), 3.66-m (12-ft) fuel length, $0.82-\mathrm{cm}(0.323-\mathrm{in}$.$) pellet 00$; BWR: 49 rods with $95 \%$ TD U02 fuel, $3.66-\mathrm{m}(12-\mathrm{ft})$ fuel length, $1.06-\mathrm{cm}$ (0.417-in.) pellet OD. 


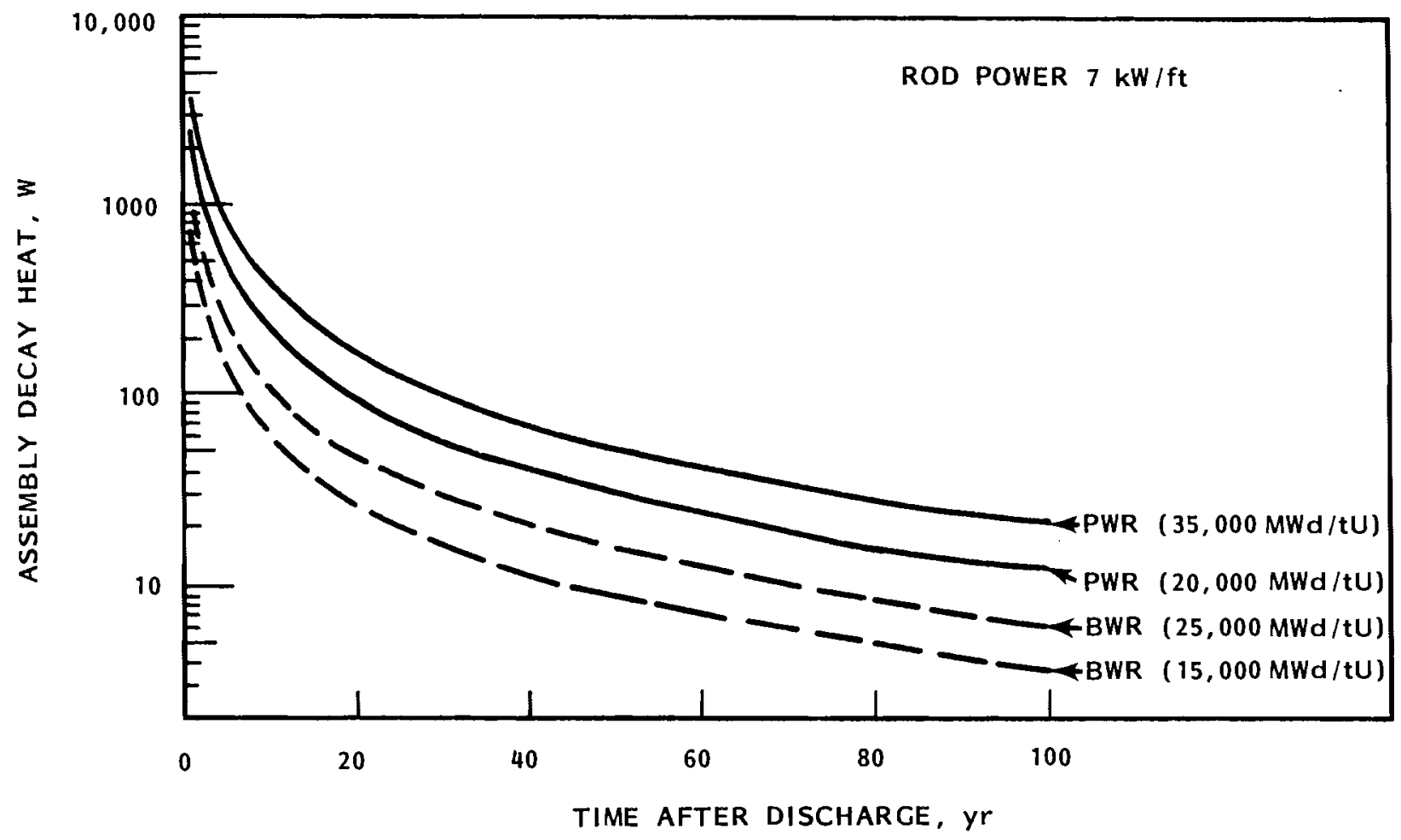

FIGURE 15. Decay Heats in Typical PWR and BWR Assemblies

Decreases in decay heat result in corresponding decreases in fuel assembly storage temperature with time, and the resistance of fuel rods to degradation during storage depends on the storage temperature. Consequently, maximum temperature limits for dry storage are directed to limiting fuel rod degradation. To date, temperature 1 imit estimates ${ }^{(39)}$ are largely based on the unirradiated properties of the fuel cladding. For these reasons, it seems prudent to examine the effects of anticipated storage temperature on fuel rod cladding properties induced by fast neutron irradiation during prior fuel duty cycles.

\section{ANNEALING OF RADIATION DAMAGE}

Annealing of radiation damage is a time-temperature thermal process that causes a change in cladding properties. The annealing process tends to restore properties to the preirradiation state and is associated with an increase in ductility and decreases in strength and resistance to failure by creep rupture. 
Investigations $(78,79)$ of thermal recovery and annealing behavior of irradiated Zircaloy under isothermal and nonisothermal heating conditions suggest that recovery and annealing mechanisms are unlikely to be activated at dry storage temperatures below $250^{\circ} \mathrm{C}$. Annealing of radiation damage is sensitive to irradiation conditions, annealing conditions, alloy composition, and the thermal-mechanical processing history of the materials being evaluated. As shown in Figure 16, the effects of annealing on irradiation-enhanced yield stress and proportional limit vary up to $200^{\circ} \mathrm{C}$ for annealed tensile specimens produced from Zircaloy plates ${ }^{(78)}$ when compared with spent fuel cladding that was stress-relieved prior to irradiation. (79) Because of the sensitivity of radiation damage annealing tc materials, irradiation, and testing variables, each batch of Zircaloy must be characterized individually if highly accurate assessments of its annealing behavior are required.

\section{STRAIN RATE EFFECTS}

Figure 17 illustrates a phenomenon to be considered in technology studies related to dry storage of Zircaloy-clad fuel. The figure indicates that relative strain energy absorption/dissipation to failure (SEAF) effects depend on strain rates imposed by the system. For example, a fuel rod with an internal pressure will be subject to a hoop stress that has an associated strain rate at a given temperature. Interstitial-dislocation interactions enhance strain rate sensitivity and susceptibility to low SEAF. $(80,81)$ SEAF is an engineering failure index and quantatively represents the area under the stress versus strain curve. As an engineering failure index, it takes into account the yielding, strain to failure, reduction in area, and other strain rate and environment-dependent characteristics $(a)$ of the material.

Figure 17 shows effects of both strain rate and radiation. Under the conditions illustrated, prior irradiation reduced the SEAF by 60 to $70^{\circ} \mathrm{C}$. It is not clear whether dry storage regimes include the SSRE or SCC conditions

(a) For example, drop-in-load yielding, dynamic strain aging, slow strain rate embrittlement (SSRE), and SCC. 


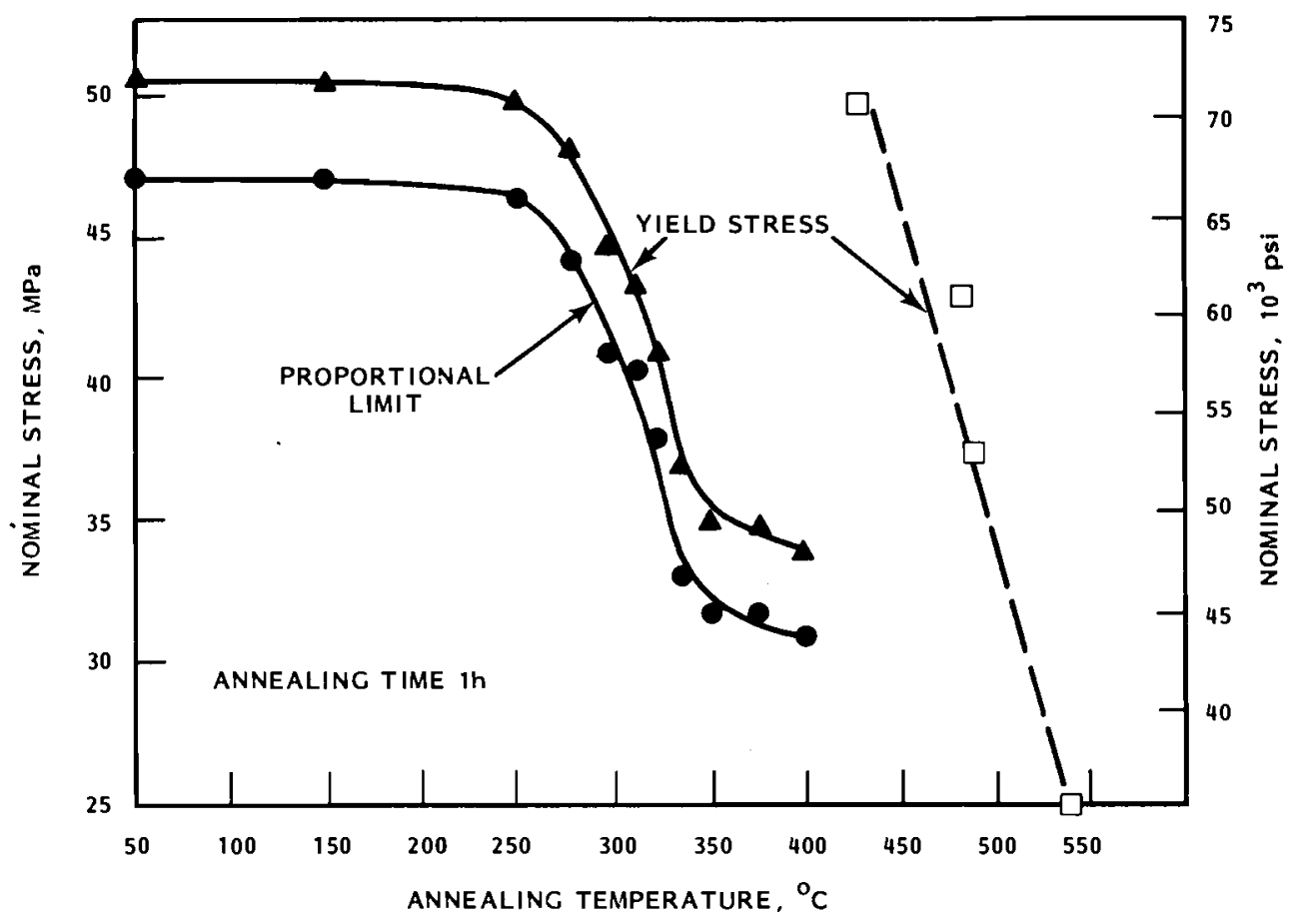

FIGURE 16. Isochronal Annealing Curve for Annealed Zircaloy-2 Irradiated at $50^{\circ} \mathrm{C}$ with $9.1 \times 10^{19} \mathrm{n} / \mathrm{cm}^{2}$. The corresponding curv? for specimens irradiated at $280^{\circ} \mathrm{C}$ is similar. (78) open a points represent comercial PWR fuel rods irradiated to burnups of $\sim 30,000$ MWd/MTM (Zircaloy-4 cladding). (79)

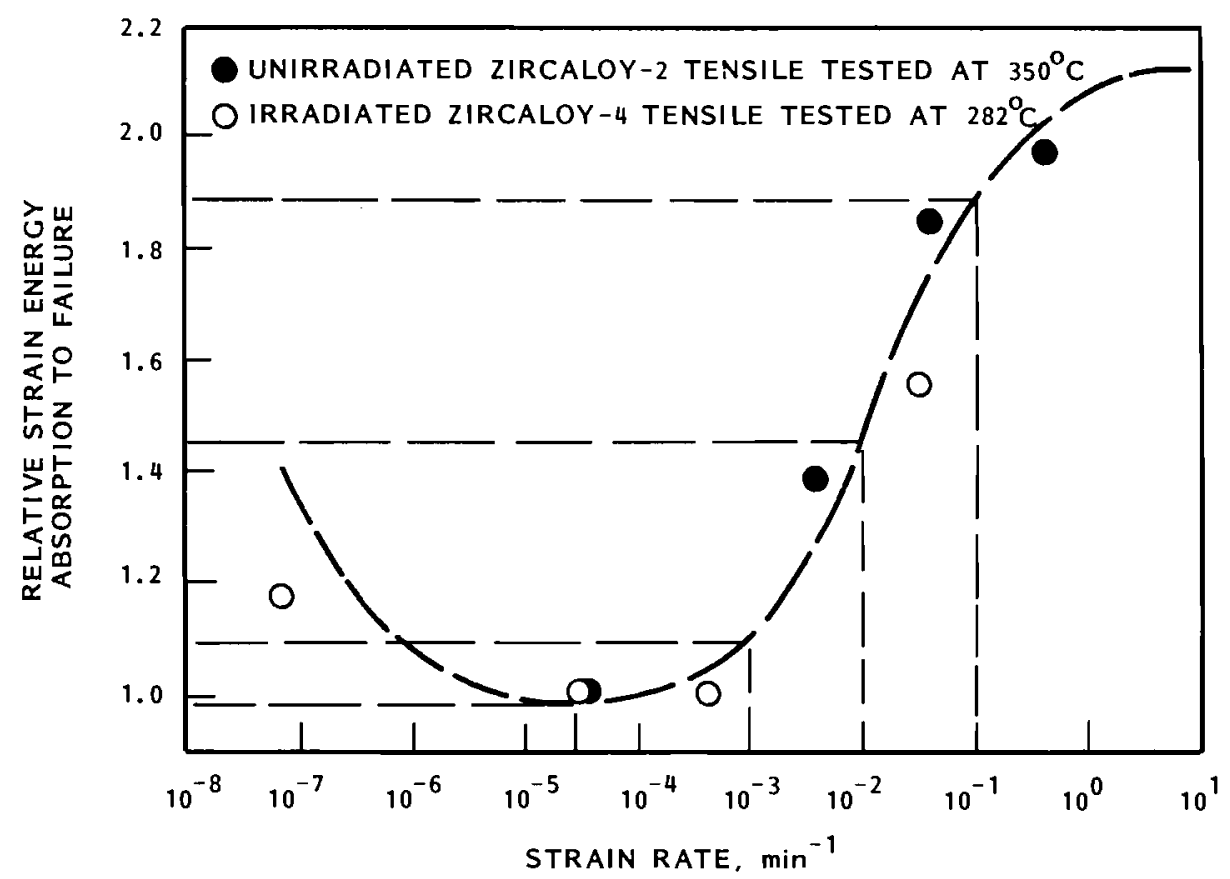

FIGURE 17. Strain Rate and Prior Irradiation Effects on SEAF 
suggested by Figure 17. Preliminary estimates suggest that strain rates on Zircaloy cladding in dry storage regimes must be considerably lower than the critical strain rates indicated in Figure 17. A substantial number of Zircaloy-clad fuel rods (BWR, PWR, PHWR, and OCR) in dry storage demonstrations are being subjected to temperatures that span the expected range for dry storage of water reactor fuel. Postirradiation creep experiments being conducted by KWO are expected to provide useful insights to strain-rate-induced phenomena. (37) Work under way at Argonne National Laboratory (ANL) on examination of dislocation channeling for Zircaloy will also contribute to the basic understanding of the mechanical behavior of irradiated Zircaloy. (82) Spent unreprocessed fuel rods may be ranked regarding the likelihood for rupture during dry storage:

- Fuel rods with reactor-induced cladding defects are not candidates for rupture. Studies are under way to determine the storage characteristics of defective rods in inert cover gases and at low temperatures in oxidizing cover gases.

- Nonfailed, nonpressurized fuel rods that operated at relatively low power and experienced minimal power cycling during reactor operation contain small amounts of volatile and releasable fission products; the rods are not likely to fail because internal pressures are relatively low.

- Nonf ailed, nonpressurized fuel rods that operated at relatively high power and/or experienced considerable power cycling are next in susceptibility.

- Nonf ailed, nonpressurized fuel rods that operated to extended burnups ( $>40 \mathrm{MWd} / \mathrm{tU}$ ) at intermediate- to high-power levels and/or experienced considerable power cycling have higher susceptibility for rupture. There are few of these fuel rods in the current inventory of spent unreprocessed fuels. 
- Nonfailed, prepressurized fuel rods are likely to have the highest susceptibility for rupture, and this susceptibility is higher for rods that experienced high power levels and power cycling. BWR rods generally have lower internal pressures than PWR rods with similar exposures.

If the fuel rod design (cladding thickness, radius to thickness ratio, etc.) and prior duty minimize the likelihood for inelastic deformation at nearcritical strain rates, the risk of failure is also minimized.

Monitoring of Zircaloy-clad fuel in dry storage demonstrations and tests $(12,18,37)$ to date has not indicated that cladding failures have occurred, based 1 argely on the absence of ${ }^{85} \mathrm{Kr}$ in cover gases. Additional similar evaluations are planned and will be supplemented by detailed nondestructive and hot cell examinations. Those examinations should factor in cognizance of phenomena that could signal activation of strain-rate-induced effects on Zircaloy under dry storage conditions.

REACTOR AND STORAGE REGIMES

Factors that may influence fuel assembly behavior for reactor operation, dry storage, and wet storage are presented in Table 14. An "X" suggests that the factor is potentially significant. Reactor operation has the most potential impacts. Hoop stresses due to unopposed internal rod pressures and extended time are probably the most significant factors for dry storage. Defects may also be significant, particularly if the cover gas has oxidizing species. Table 15 provides a more quantitative comparison of selected exposure parameters, indicating that there is a broad potential range of temperatures and internal rod pressures in dry storage. Gamma and neutron radiation levels are much lower in dry storage than in the reactor. Neutron fluxes are too low to cause significant changes in material properties, although they must continue to be considered in criticality and shielding analyses. Gamma fluxes are sufficiently high that radiolytic effects cannot be ruled out for certain species (for example, nitric acid formation if moisture and nitrogen levels are sufficiently high). 
TABLE 14. Factors Affecting Fuel Rod Degradation

\begin{tabular}{|c|c|c|c|}
\hline Factor & In-Reactor & Dry Storage & Pool Storage \\
\hline Power ramping & $x$ & & \\
\hline $\begin{array}{l}\text { Fission product release } \\
\text { from fuel pellets }\end{array}$ & $x$ & & \\
\hline Fuel-induced stress & $x$ & & \\
\hline Chemical heterogeneity & $x$ & $x$ & $x$ \\
\hline Iodine decomposition & $x$ & & \\
\hline Hoop stress & & $x$ & \\
\hline Hydrides & $x$ & $x$ & $x$ \\
\hline Temperature & $x$ & $x$ & \\
\hline Time & (a) & $x$ & $x$ \\
\hline Irradiation effects & $x$ & (b) & \\
\hline Defects & $x$ & $x$ & $x$ \\
\hline
\end{tabular}

(a) Increasing importance for extended burnup operation.

(b) Residual effects may be significant.

Definition of terms used in Table 14:

Power ramping: Rapid changes in reactor power have contributed to some types of reactor-induced cladding failures; for example, pellet-cladding interaction (PCI).(51)

Fission product release: Pellet temperatures in storage regimes are much Tower than in the reactor (Table 15); pellet oxidation during storage could contribute to some fission product evolution.

Fuel-induced stress: Relative thermal expansions for Zircaloy and $\mathrm{U}_{2}$ suggest that PCI will diminish as temperatures decrease.

Chemical heterogeneity: Potentially reactive species exist on both sides of the cladding: fission products on the inside; and reactor coolant, cover gases, or pool water on the outside. None of the exterior species offer a substantial threat to the cladding under normal operation. Inert cover gases preclude significant reactions in dry storage regardless of temperature. 


\section{TABLE 14. (contd)}

Iodine decomposition: Assessments suggest that reactor radiation may cause decomposition of otherwise-stable iodine compounds (for example, CSI) that form soon after fission product iodine is released from the fuel pellets during reactor operation. (83) Radiation levels in storage are several orders of magnitude lower than in-reactor (Table 15), probably precluding decomposition or a source of active iodine.

Hoop stress: Hoop stresses on fuel cladding due to internal pressures tend to be opposed by reactor operating pressures; at higher dry storage temperatures substantial hoop stresses can develop, particularly for prepressurized PWR rods.

Hydrides: Hydrogen enters Zircaloy cladding during reactor operation and precipitates as hydrides when the cladding temperature drops below the hydrogen solubility limit. The hydrides remain in the cladding during storage but will dissolve into the cladding if the storage temperature exceeds the solubility limit.

Temperature: The highest projected dry storage temperatures are similar to cladding temperatures during reactor operation; however, much of the stored LWR inventory $c$ an be stored at temperatures substantiallv below in-reactor cladding temperatures. Dry storage temperatures $w i^{-}$decline continuously. Wet storage temperatures typically are 25 to $4 \mathrm{C} \backsim$.

Time: Reactor residence for water reactor fuel is typically 3 to $4 \mathrm{yr}$, although extended burnup may lengthen the times by 1 to $2 \mathrm{yr}$. Spent fuel residence in interim storage may extend for several decades.

Irradiation effects: Irradiation causes decreases in cladding ductility and increases in strength. These changes have not had significant impacts on Zircaloy-clad fuel assembly behavior in wet storage. Effects on dry storage characteristics have not emerged but are being evaluated in dry storage demonstrations.

Defects: Water reactor fuel with reactor-induced cladding defects has had minimal impacts on wet storage. Storage philosophies and possible impacts of defective cladding in dry storage are being addressed in dry storage development programs. 
TABLE 15. Comparison of Fuel Exposure Conditions

\begin{tabular}{|c|c|c|c|c|c|}
\hline \multirow[b]{2}{*}{ Parameter } & \multicolumn{3}{|c|}{ In-Reactor } & \multirow[b]{2}{*}{ Wet Storage } & \multirow[b]{2}{*}{ Dry Storage } \\
\hline & BWR & PWR & HWR & & \\
\hline $\begin{array}{l}\text { Fuel Centerline } \\
\text { Temperature, }{ }^{\circ} \mathrm{C}\end{array}$ & 1400 to 1800 & 1200 to 1700 & 1300 to 1700 & $100(a)$ & $\begin{array}{l}\text { to } \sim 70^{\circ} \mathrm{C} \text { above claddding } \\
\text { temperature }\end{array}$ \\
\hline $\mathrm{Cl}$ adding ID Temperature ${ }^{\circ} \mathrm{C}$ & 320 to 360 & 340 to 370 & 300 to 350 & 30 to $60(a)$ & $\begin{array}{l}\text { to } \sim 10^{\circ} \mathrm{C} \text { abqve storage } \\
\text { temperature }(\mathrm{b})\end{array}$ \\
\hline $\begin{array}{l}\text { Pressure Inside Fuel } \\
\text { Rod, atm }\end{array}$ & 5 to 50 & 40 to 150 & 25 to 100 & $(c)$ & $\begin{array}{l}1.7 \times \text { RT pressure for } 250^{\circ} \mathrm{C} \\
2.2 \times \text { RT pressure for } 400^{\circ} \mathrm{C}\end{array}$ \\
\hline $\begin{array}{l}\text { Pressure Outside Fuel } \\
\text { Rod, atm }\end{array}$ & 70 & 140 to 160 & 70 to 110 & up to 2 & subatmospheric \\
\hline $\begin{array}{l}\text { Fission Gas Released to } \\
\text { Fill Gas, } \%\end{array}$ & 1 to 11 & 1 to 13 & 2 to 18 & (d) & (d) \\
\hline $\begin{array}{l}\text { Typical Assembly Burnup, } \\
\text { MWd/tU }\end{array}$ & 27,000 & 35,000 & 7,000 & $\begin{array}{l}\text { same as } \\
\text { in-reactor }\end{array}$ & same as in-reactor \\
\hline OD Heat Flux, $W / \mathrm{cm}^{2}$ & 70 & 100 & 100 & $0.03(e)$ & $0.03(e)$ \\
\hline $\begin{array}{l}\text { Neutron Flux, >1/MeV } \\
\mathrm{n} / \mathrm{cm}^{2}-\mathrm{s}\end{array}$ & 4 to $6 \times 10^{13}$ & 5 to $6 \times 10^{13}$ & 4 to $6 \times 10^{13}$ & $\sim 10^{4}$ to $10^{6}$ & $\sim 10^{4}$ to $10^{6}$ \\
\hline Gamma Field, rem/h & $\sim 109$ & $\sim 109$ & $\sim 109$ & $\sim 105(\mathrm{e})$ & $\sim 105(e)$ \\
\hline Power Changes & substantial & substantial & substantial & minimal & negligible \\
\hline
\end{tabular}

(a) Nominal value shortly after discharge; depends on water temperature and decreases with the age of the spent fuel.

(b) Expected dry storage temperatures range from $\sim 150$ to $400^{\circ} \mathrm{C}$, depending on concept and fuel type.

(c) Approximately one-half of the in-reactor pressure.

(d) Additional fission gas release during storage is negligible.

(e) Decreases with the age of the spent fuel. 
The current inventory of spent unreprocessed fuel represents a variety of duty cycles (for example, burnup and operating mode), fuel rod design and assembly configurations, and, to a lesser extent, component materials. The most common characteristic of all spent unreprocessed fuel rods is that they each, by virtue of the cladding, contain fission product radionuclides, some of which are or may be:

- volatile at virtually any temperature $\left({ }^{85} \mathrm{kr}\right)$

- volatile at intermediate and/or high temperatures ( $I_{2}, C s$, and $C d$ )

- solid at all anticipated temperatures ( $\mathrm{Pu}, \mathrm{U}, \mathrm{Fe}, \mathrm{Ti}$, and Te).

Beyond the cladding containment characteristics, there can be many differences between fuel rods and assemblies (see Table C.2, Appendix C). Some differences are attributable and specific to plant type, duty cycle, and even evolutionary changes in design and materials arising from prior operating experience. The cladding containment characteristic and function, however, are not expected to change significantly in the forseeable future.

In BWR fuel assemblies, the entire weight is carried by eight peripheral fuel rods (tie rods) during all handling operations in the core, in interim pool storage, and during transport to terminal storage and/or reprocessing. In PWR fuel assemblies, the control rod guide tubes or bars provide the loadcarrying functions. All LWR fuel assemblies are designed to function even when some tie rods or guide tubes or bars are damaged. Any prior duty damage of major significance to the load-carrying function of the cladding should be evident during in-core handling and/or at final discharge of the spent fuel. In-core and interim storage mishandling incidents have occurred, but few fuel assemblies have been severely damaged during handling and no fuel handling incident has resulted in serious consequences. (34)

Based on this experience with the current inventory of spent unreprocessed fuels, handing loads appear to be of minor significance relative to interim and/or terminal dry storage. For nonfailed fuel rods, the principal function of the cladding, therefore, is to contain solid and volatile radionuclides. For failed fuel rods, the cladding contains fuel, solid radionuclides, and, at least in some rods, water or vapor trapped in the fuel rod during reactor operation and/or interim pool storage. 
The current spent fuel inventory includes a small number of rods with cladding that has inside diameter (ID) cracks that have not propagated to failure. An FRG publication indicated that these incipient defects appear infrequently; ${ }^{(12)}$ and defects larger than $300 \mu \mathrm{m}$ have been observed in KWU fuel. (37) Both fill gas and fission gas pressure will act on the cladding. The volatile fission product content depends on the prior duty (burnup and power cycling) and therefore has a range of values. $(32,82,84)$ The internal fuel rod pressures in spent unreprocessed fuel are expected to be only a fraction of the reactor primary coolant pressure ( 1000 psi for BWRs and 2250 psi for PWRs) even though technical specifications (see, for example, the safety analysis report for any 1 icensed $p l a n t$ ) may permit pressures up to the primary system pressure. Based on these considerations and the expected envelope of dry storage conditions, it seems very unlikely that failures will occur within the current inventory of spent unreprocessed fuel by any of the following mechanisms:

- simple mechanical overloading

- fatigue cracking by cyclic loading

- brittle cracking under linear elastic loading.

For fuel rods with reactor-induced cladding defects, it is expected that if failure were to occur by one of these mechanisms, it would be more likely during handling and transporting operations than during interim and/or terminal dry storage. $(19,85,86)$

\section{ZIRCALOY STRESS CORROSION CRACKING}

Stress corrosion of Zircaloy cladding is a phenomenon that develops from the fuel side. To date it has been observed only during reactor operation. No known cases have occurred during wet interim storage or during the dry storage demonstrations that have been evaluated.

The SCC phenomenon is characterized by cladding cracks that appear to generally develop during rapid increases in reactor power. The conditions leading to SCC do not develop in the great majority of fuel rods, even for fuel assemblies that have resided in the reactor for $17 \mathrm{yr}(12.3 \mathrm{yr}$ at reactor operating conditions) $)^{(87)}$ and $16 \mathrm{yr} .{ }^{(88)}$ Most metallurgical examinations of irradiated 
Zircaloy-clad fuel do not show evidence of fisson product attack or SCC initiation, although there are exceptions. ${ }^{(89)}$ Primary SCC failures have been described as "small, tight cracks." ${ }^{(90)}$ Secondary mechanisms such as cladding hydriding and fuel oxidation have caused small primary cracks to enlarge in-reactor. In wet storage, reactor-induced defects do not appear to propagate. ${ }^{(37)}$ In dry storage, development of small cladding cracks would release volatile gases (principally ${ }^{85} \mathrm{Kr}$ ) to the cover gas. However, if the storage environment is inert or the storage temperature is sufficiently low to preclude fuel oxidation, then there is no obvious mechanism to propagate cladding defects.

The SCC failure mode may be intergranular and/or transgranular and is probably related to strain rate. ${ }^{(89)}$ The hypothes is for the failures involves a combination of high local cladding stress and chemical attack by aggressive fission products, leading to a phenomenon commonly characterized as PCI.

Laboratory studies and hot cell examinations of irradiated Zircaloy cladding have been conducted to attempt to identify the aggressive fission products. Iodine has been the leading candidate for causing Zircaloy to crack, based on numerous laboratory studies. The cracks have morphologies similar to cracks associated with in-reactor PCI failures; however, there is a complex fission product inventory inside the fuel rods. Species other than iodine (including cesium and cadmium) have been suggested as participants in the PCI failures. $(91,92)$ Some examinations of irradiated fuel are beginning to provide insights to species on the interior surfaces of the cladding. $(83,93)$

Laboratory studies have investigated the effects of various parameters on Zircaloy SCC, $(85,94)$ including temperature, stress state, fission product species and concentrations, and metallurgical factors.

Under dry storage conditions certain factors appear to mitigate the prospects for SCC to occur (Table 14), principally the absence of rapid temperature ramps and high fuel temperatures conducive to further evolution of fission products from the fuel pellets. Some fission products (for example, certain short-lived iodine isotopes) that could participate in in-reactor failures are no longer present in the extended times of interim storage. 
Fuel rod internal pressures, particularly for prepressurized PWR rods, provide significant stresses during elevated temperatures in dry storage. The fact that temperatures are decreasing with time results in corresponding decreases in pressure (and hoop stress) with increasing residence in dry storage.

Additional studies are planned or under way that will focus on SCC under dry conditions. However, perhaps most valuable will be examination of the behavior of Zircaloy-clad fuel in the various dry storage demonstrations over a broad range of temperatures and fuels, including BWR, PWR, and PHWR fuels. These demonstrations will also include monitoring for rod failures and hot cell examinations to characterize failures if they occur.

CREEP AND STRESS RUPTURE PROPERTIES

Conditions for stress rupture of Zircaloy cladding as a consequence of internal pressure have been analyzed. ${ }^{(38)}$ Internal fuel rod pressures develop from volatile fission products produced in and released from the fuel pellets during prior duty cycles and the fill gases added during manufacture.

Until recently, there were no creep or stress rupture data for irradiated Zircaloy cladding on unreprocessed spent LWR fuel rods. There are significant data relative to the creep deformation of the Zircaloy cladding in high-energy $(E \geq 1 \mathrm{MeV}$ ) neutron irradiation environments but no long-term data relative to stress rupture behavior. For this reason, Blackburn et al. (39) attempted to use the creep and stress rupture data available for unirradiated Zircaloy to estimate the time-to-f ailure by creep for the irradiated cladding and spent unreprocessed fuel rods. Blackburn reasoned that: "Although substantial irradiation hardening and reduced ductility in short-term tests is known to result from reactor service, it is possible that time-to-rupture in creep tests is not markedly affected since irradiation hardening can lower the creep rate and result in little change in failure times in spite of reduced ductility. Zirconium alloys do not appear to be susceptible to helium embrittlement-type effects as are the stainless steels; therefore, the large irradiation-induced reductions in rupture 1 ife of stainless steels may not be typical of Zircaloy fuel cladding." 
Stress rupture data on irradiated fuel rods have been generated by Yaggee et al. $(95,96)$ at ANL. The program involved spent fuel cladding from the H. B. Robinson (HBR), Quad Cities (QC), Big Rock Point (BRP), and Oskarshamn (OSK) reactors. Neutron fluences ranged from 0.6 to $6 \times 10^{21} \mathrm{n} / \mathrm{cm}^{2}$ ( $\mathrm{E}>0.1 \mathrm{MeV}$ ); fuel burnups, from 6 to $30 \mathrm{MWd} / \mathrm{kgU}$; and test temperatures, from 325 to $360^{\circ} \mathrm{C}$. The cladding conditions are summarized in Table 16 . The spread in test conditions makes it convenient to compare the data to the predictions with the Larson-Miller Parameter (LMP) in the format presented by Blackburn. (39) The LMP is a temperature-compensated time parameter defined as :

$$
L M P=T(20+\log t)
$$

where $\mathrm{T}=$ temperature, ${ }^{\circ} \mathrm{R}$

$t=t i m e, h$.

The data have several limitations that weaken their extrapolation to dry storage conditions, but the addition of data and experience with stress rupture on irradiated fuel rods is useful. The limitations are primarily in the brevity of the tests, the high temperatures, and the hoop stresses. The high temperatures and stresses were imposed to induce rupture in a reasonably short time (the ANL tests produced rupture in less than $100 \mathrm{~h}$ ).

The ANL stress rupture data are shown in Figures 18 and 19 for spent fuel cladding from the Oskarshamn-1, Big Rock Point, and H. B. Robinson reactors; the stress rupture data for unirradiated Zircaloy-2 used by Blackburn to develop the LMP correlations for stress-relieved and annealed tubing are also shown. The results for irradiated spent fuel correlate better with cold-worked unirradiated cladding than with annealed cladding. It is interesting that the Oskarshamn fuel rod data are above the data for unirradiated cold-worked cladding even though they were manuf actured from annealed Zircaloy-2 cladding.

The stress rupture studies on irradiated fuel rods were conducted at temperatures considerably above those expected for dry storage and at pressures much higher than normal for spent fuel rods. Test durations were relatively short; consequently, extrapolation is required to lower temperatures, lower 
TABLE 16. Summary of Irradiated Zircaloy Cladding Materials Used in Iodine SCC Tests

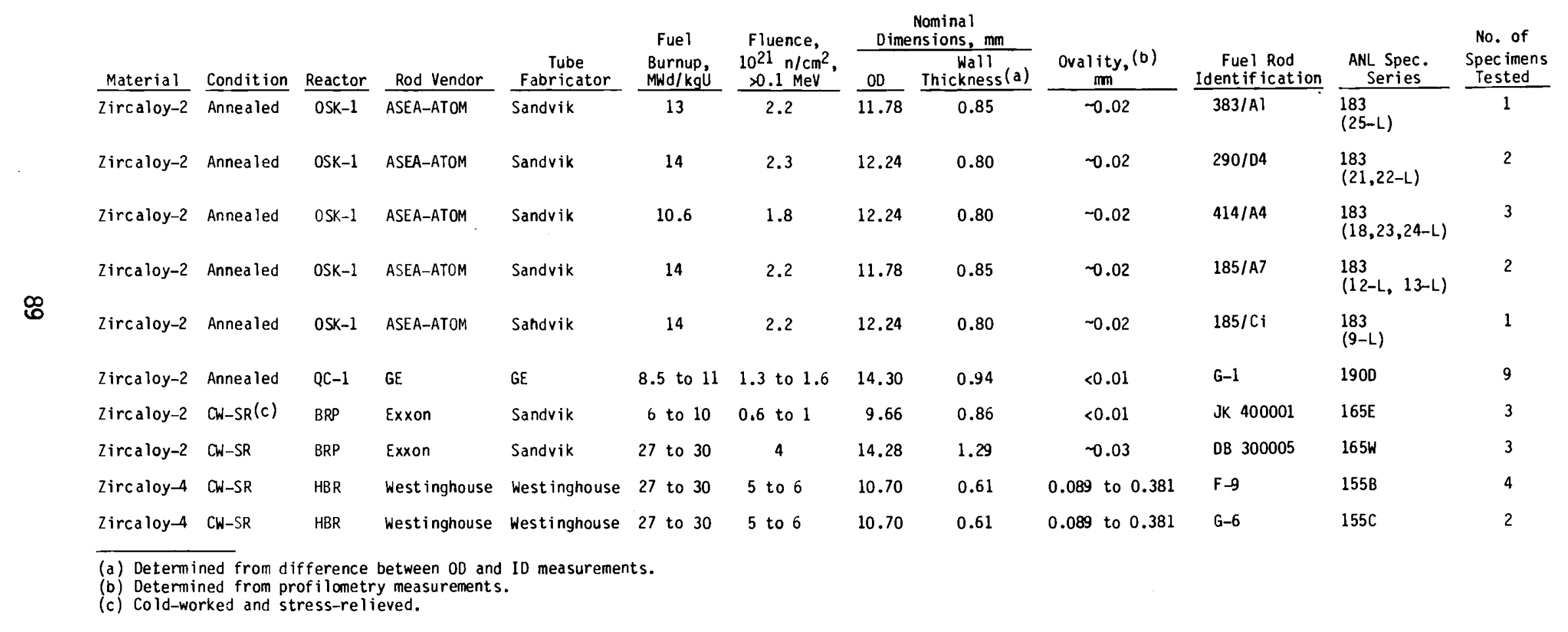




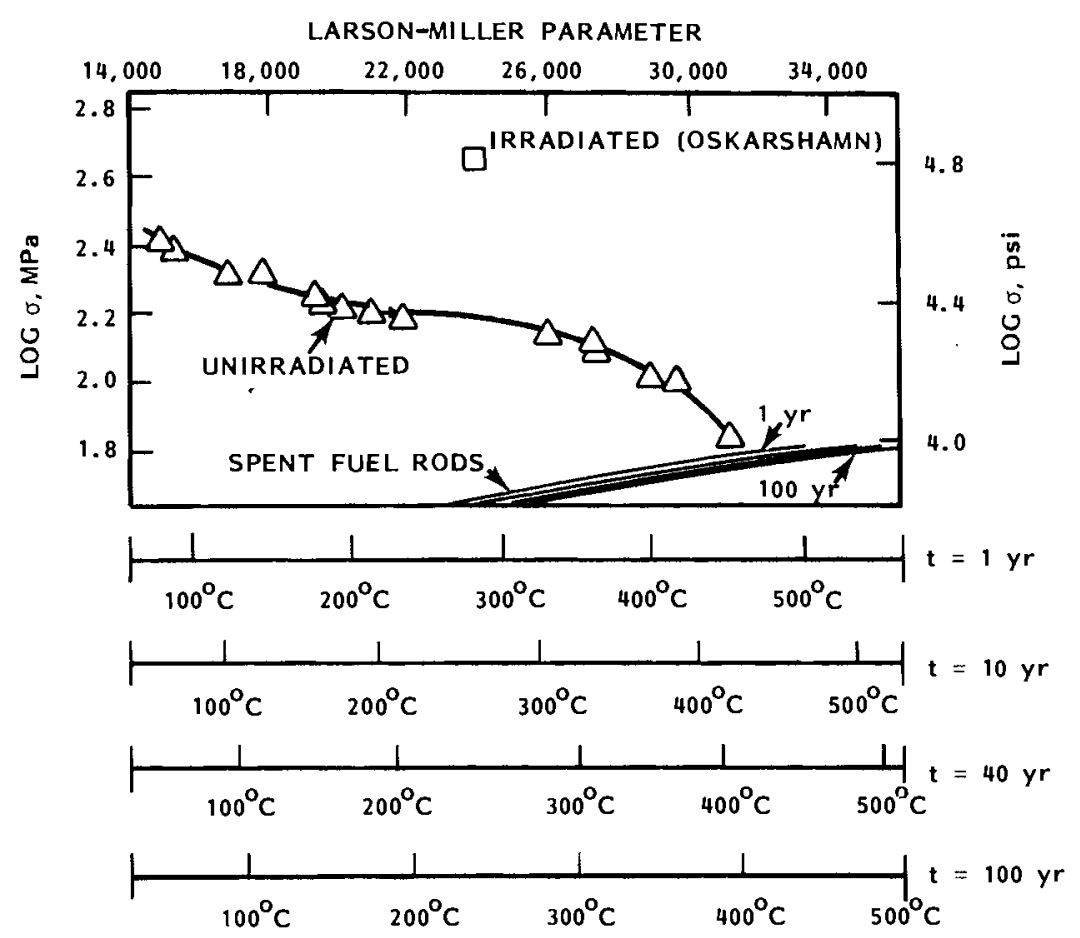

FIGURE 18. Comparison of Stress Rupture Results for Annealed $Z$ caloy-2

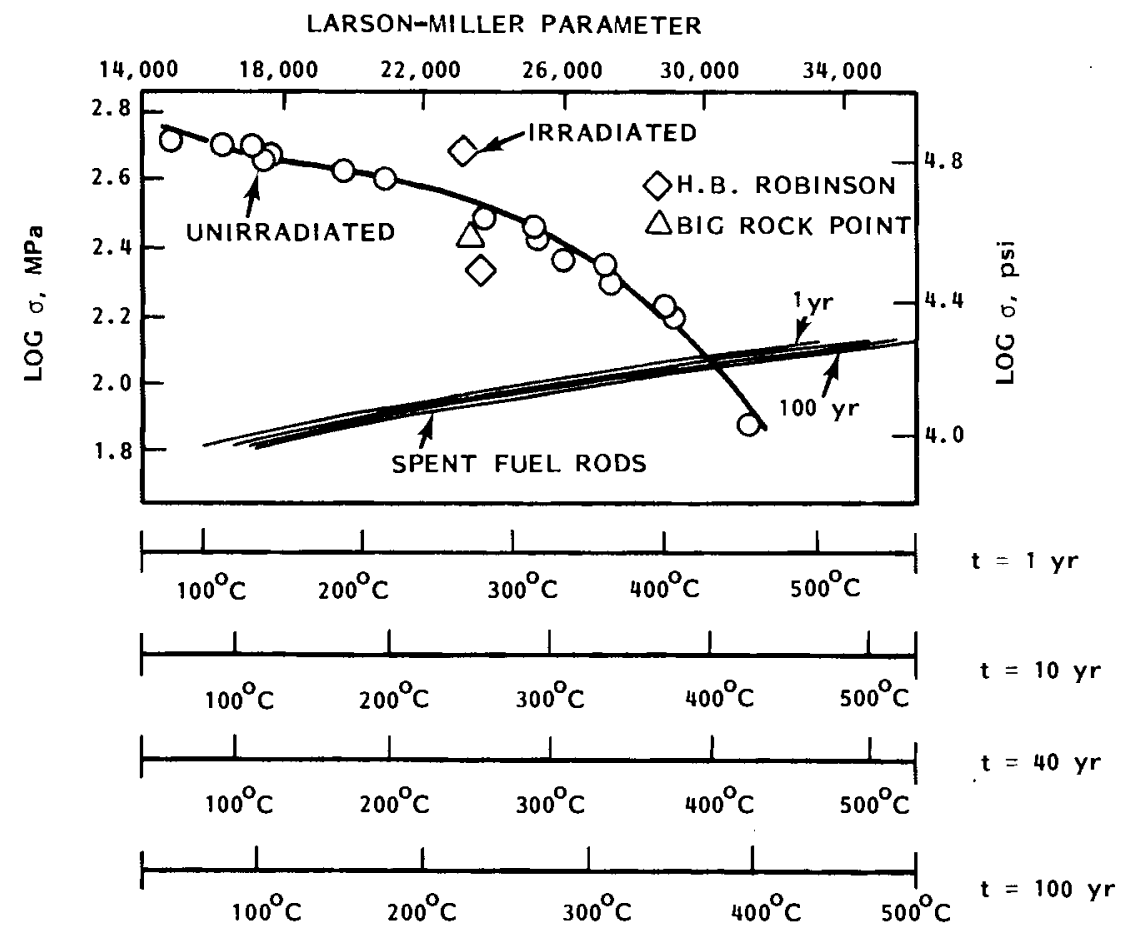

FIGURE 19. Comparison of Stress Rupture Results for Stress-Relieved Zircaloy-2 
stresses, and longer times. The LMP value for $40 \mathrm{yr}$ at $250^{\circ} \mathrm{C}$ in the units of Figures 18 and 19 is 24,037; consequently, it is we 11 bracketed by existing data. However, the laboratory tests must use elevated temperatures or pressures to compensate for times up to $350,000 \mathrm{~h}$ in dry storage through the LMP. Examination of failure maps for other materials $(97,98)$ show that extrapolations may extend into regions of other failure modes and changes of ductility.

Concerns exist for extrapolation of rupture data under high test stresses to the low stresses of spent fuel rods. High stresses have greater potential for activating failure by SCC. A change in failure mode occurs as stress rupture tests are conducted at lower stresses. Methods of extrapolating the dependence of stress rupture over large stress and time ranges with compensation for changing cracking modes are not well developed. The transition to diffusional-controlled creep and intergranular failure modes leads to steeper slopes on LMP plots. A change to a steeper slope is observed in Figures 18 and 19 at lower values of stress approaching 10,000 psi. In that respect, the LMP correlation appears to show compensation for changing modes of deformation and failure, even though its development was linearly based.

A comparison of the cladding stresses generated in LWR fuel rods from prepressurization $g$ as and radiation-induced fission gas with the stress rupture properties in Figures 18 and 19 shows a tendency for the curves to converge above $400^{\circ} \mathrm{C} .(39)$ For this reason, $400^{\circ} \mathrm{C}$ is considered an upper temperature limit for fuel storage in inert atmospheres.

\section{HYDROGEN EFFECTS IN ZIRCALOY CLADDING}

Hydriding characteristics of Zircaloy are summarized in Appendix $C$. The key aspects of hydrogen behavior in Zircaloy are:

- Terminal solubilities for hydrogen in Zircaloy increase with increasing temperature (see Table 17).

- If total hydrogen exceeds the terminal solubility, solid hydrides will precipitate, principally in grain boundaries.

- Hydrogen will diffuse down a temperature gradient (from higher to lower temperatures) in Zircaloy.

- Hydride orientations are influenced by stresses. 
TABLE 17. Terminal Solubilities for Hydrogen in Zircaloy as a Function of Temperature (99)

$\begin{array}{cc}\text { Temperature, }{ }^{\circ} \mathrm{C} & \text { Terminal Solubility, wppm } \\ 250 & 30 \\ 300 & 60 \\ 350 & 120 \\ 400 & 200 \\ 500 & 480\end{array}$

After normal reactor residence, typical hydrogen contents in Lircaloy cladding are 80 to $150 \mathrm{wppm}$. At $30^{\circ} \mathrm{C}$ the hydrogen solubility limit is very low, and most of the hydrogen has precipitated under wet storage conditions. At $250^{\circ} \mathrm{C}$ the hydrogen solubility is $\sim 30 \mathrm{ppm}$; rods with higher hydrogen contents will have some solid hydrides remaining. As the temperature in dry storage decreases, the hydrogen will reprecipitate. However, stress levels and stress directions in the cladding are likely to differ in dry storage and during reactor operation, particularly for prepressurized PWR fuel due to hoop stresses generated by the internal pressure. During reactor operation, stresses are opposed by reactor system pressures that are not present in dry storage. Changes in hydride orientation in spent fuel cladding under tensile hoop stresses have been reported. (96) At 350 to $400^{\circ} \mathrm{C}$, essentialiy all hydrogen that entered the Zircaloy cladding during reactor operation will be in solution. Reprecipitation of hydrides will occur as temperatures drop to levels corresponding to terminal solubility limits specific to each rod location.

There is direct evidence from dry storage demonstrations that substantial axial temperature gradients develop on Zircaloy-clad fuel. $(18,37)$ Sawatzky $(100)$ has developed a theoretical and experimental perspective of hydrogen behavior in Zircaloy that is subject to thermal gradients. They have clearly demonstrated that hydrogen will migrate to cooler locations if the thermal gradient is sufficient. Some attention should be given to assessing the hydrogen redistribution when fuel from dry storage demonstrations is examined. The assessments should address the effects of thermal gradients and stress fields on redistribution of hydrogen in Zircaloy cladding. 
Canadian investigators have concluded that delayed hydrogen cracking explains the degradation of $\mathrm{Zr}-2.5 \mathrm{Nb}$ pressure tubes at the Pickering power station. ${ }^{(101)}$ The cracking occurred at relatively low temperatures $\left(\sim 150^{\circ} \mathrm{C}\right)$ and involved high stress intensity factors. Zircaloy-2 pressure tubes were less susceptible to hydrogen-induced cracking than the $\mathrm{Zr}$-Nb tubes, presumably due to lower Zircaloy yield stresses. The fact that irradiation increases the yield stress should be considered in assessments of hydrogen effects in Zircaloy cladding under dry storage conditions.

CHARACTERISTICS OF FUEL CRUD AND ITS POTENTIAL IMPACT ON DRY STORAGE

The term crud refers to deposits that develop over the $\mathrm{ZrO}_{2}$ film on the cladding surface. Crud develops because most metals in the reactor coolant circuit (iron-, nickel-, and cobalt-base alloys) release substantial fractions of corrosion products to the circulating coolant. 0xides on zirconium alloys generally remain in place.

Circulating corrosion products generally deposit on fuel rod heat transfer surfaces. The nature and composition of the reactor environment and the associated deposits are:

\begin{tabular}{|c|c|c|}
\hline Type of Reactor & Coolant Conditions & Fuel Crud Compositions \\
\hline BWR & $\begin{array}{l}\text { Neutral } \mathrm{pH} ; 0.1 \text { to } \\
0.3-\mathrm{ppm} \mathrm{O}_{2}\end{array}$ & Principally $\mathrm{Fe}_{2} \mathrm{O}_{3}$ \\
\hline PWR & $\begin{array}{l}\text { Boric acid; lithium } \\
\text { hydroxide; } 15 \text { to } \\
45 \mathrm{cc} \mathrm{H}_{2} / \mathrm{kg} \text { of } \\
\text { coolant; }<0.005- \\
\text { ppm } \mathrm{O}_{2}\end{array}$ & $\begin{array}{l}\mathrm{Fe}_{x} \mathrm{Ni}_{3-x} \mathrm{O}_{4} \\
(x \sim 0.6)\end{array}$ \\
\hline
\end{tabular}

Crud Characteristics

Crud deposits on BWR fuel rods in wet storage frequently consist of a reddish-brown flocculent $\mathrm{Fe}_{2} \mathrm{O}_{3}$ outer layer and a tenacious inner layer (also principally $\mathrm{Fe}_{2} \mathrm{O}_{3}$ ), which reflects the relatively oxidizing conditions in the BWR coolant. In some BWRs, the reddish-brown layer is not evident, and the crud layer is dark. When it is present, the loose reddish-brown layer is usually washed from the fuel rods as the assemblies are moved in spent fuel pools. 
Crud thicknesses vary along the length of a fuel rod, within a given core, and from one core to another. ${ }^{(102)}$ Thus, existing characterizations of crud quantities are not precise and are at best order of magnitude.

Typical amounts of crud that are deposited on BWR fuel range from 100 to $450 \mathrm{mg} / \mathrm{dm}^{2}$. (103) The heat transfer area on the Zircaloy core of a 1000-MWe $B W R$ is $\sim 1 \times 10^{4} \mathrm{~m}^{2}$; thus, a very rough estimate would be that the crud inventory on a BWR core would be from 100 to $450 \mathrm{~kg}$. With about 560 assemblies in the core, the estimated crud weight per assembly would be $\sim 0.2$ to $1 \mathrm{~kg}$.

The crud found on PWR fuel rods is dark and generally thinner than that found on BWR rods. Crud deposits on a PWR core vary with position along the rods, $(104)$ the deposits tend to be heaviest near the top of the core, and the crud layer tends to be tenacious as it is removed from the reactor. The amount of crud deposited on a 1000-MWe PWR core was estimated to be $\sim 20 \mathrm{~kg}$ in the first year and $3 \mathrm{~kg}$ per year thereafter. ${ }^{(104)}$ After $3 \mathrm{yr}$, the estimated total crud inventory on the core would be $25 \mathrm{~kg}$. A typical PWR has ?bout 180 assemblies; therefore, the estimated crud weight per assembly wuld be $-0.15 \mathrm{~kg}$. As with BWR cores, the crud inventory on PWR cores may vary by orders of magnitude. (102) On some PWR assemblies, the shiny $\mathrm{ZrO}_{2}$ oxide is clearly evident, indicating the near absence of crud at some core locations.

Under water pool conditions, the crud layers appear to have low solubilities; however, it is not yet clear to what extent the crud layers loosen in extended pool residence. There is some evidence that dry conditions at elevated temperatures may contribute to crud spallation, but there is no systematic assessment of conditions that promote spallation. Crud behavior in dry storage is the subject of current studies.

When fuel failures occur during reactor operation, fission products circulate in the coolant and adsorb on the crud layers. In spent fuel pools, a fraction of the fission products desorb and contribute to the inventory of radioactive species in the pool water.

Two types of radioactive species are present in fuel crud:

- activation products from neutron activation of the crud species 
- fission products on cores that have developed in-reactor failures. Table 18 summarizes the principal longer lived activation and fission products associated with crud deposits.

In spent fuel pools, ${ }^{134} \mathrm{Cs}$ and ${ }^{137} \mathrm{Cs}$ are the principal species that desorb. Small amounts of ${ }^{54} \mathrm{Mn}$ and ${ }^{60} \mathrm{Co}$ are also measured in pool waters; ${ }^{65} \mathrm{Zn}$ is sometimes measurable when BWR cores are stored. Cobalt-60 is the principal activation product remaining in the crud layers in storage due to its 5.3-yr half-life. The radioactive inventories in the crud will decline to relatively low values after several decades of storage.

Crud Impacts on Dry Storage of Water Reactor Fue 1

There is very little basis to assess how mobile crud on water reactor fuel will become as a function of dry storage conditions. Observations on PWR rods heated from 480 to $570^{\circ} \mathrm{C}$ suggested that some crud spallation had occurred. (17) The amounts of crud spallation in the temperature range more typical of expected dry storage conditions are not yet characterized.

If crud particles become mobile, there are several considerations:

- Crud particles that dislodge may remain loose or they may stick to cask or canister surfaces. The sticking tendency may be significant for storage component decontamination and decommissioning.

TABLE 18. Activation and Fission Products Associated with Crud Deposits

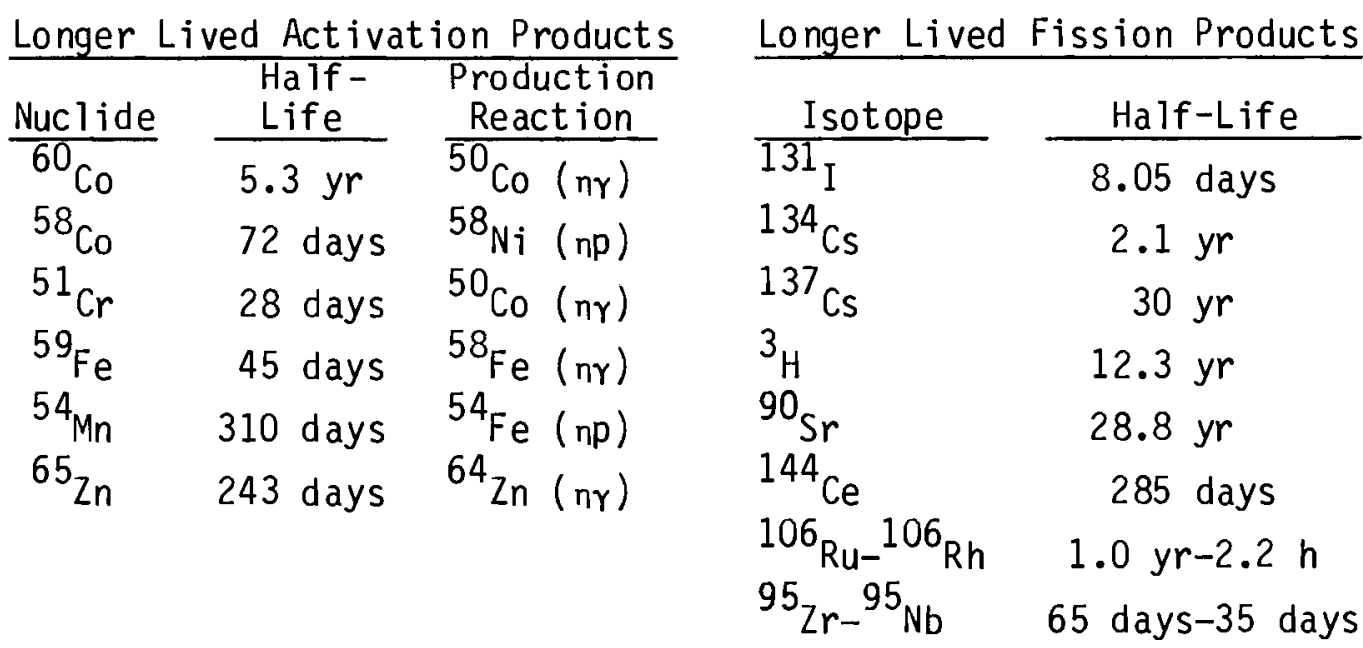


- If the fuel is uncanned and is retrieved from a storage cask or canister underwater, the loose crud particles will become part of the particulate crud inventory in the pool. Water pools are equipped with filters to control particulates; however, if considerable crud particulates were anticipated, the cask or canister might be flushed directly to a filter system possible. Alternatively, the cask could be opened in a conf ined water volume treated by filtration before mixing with pool water. Care must be taken in opening the cask to prevent gas bubbles from transporting active species to the pool surface (see Reference 35 ).

- If the fuel is retrieved dry, it most likely will be canned and handled in a hot cell. If considerable mobile crud is anticipated, special handling procedures may be useful to minimize the spread of the contamination within the cell. Aerosols are not likely to be a health hazard since they will be intercepted either by the pool water or the cell filter system.

Decontamination and decommissioning of the dry storage facility will eventually be important. If the cask and fuel baskets are properly designed to minimize crevices, crud trapping will be minimal and most loose crud will be removed by flushing. What remains undefined is the amount of crud that becomes immobilized by chemisorption on or incorporation into oxide films on cask and basket surfaces. The tendency for immobilization should be investigated as a function of temperature and cover gas. If the amount of crud attached to storage components is sufficient to require chemical or electrochemical decontamination, téchniques are available; $(45,105)$ techniques for decontaminating metallic and nonmetallic materials are in advanced stages of development. (105)

If the uncanned fuel is retrieved from dry storage under dry conditions, measures to control the crud will probably be needed; but they are not expected to be difficult. Knowledge of crud behavior during storage would be essential if the fuel were to be stored uncanned in a vault. In silos and dry wells, crud impacts would occur during retrieval and decontamination. The impacts are expected to be readily manageable if properly anticipated. 
The crud layers will probably not have a significant influence on conductive heat transfer from the fuel rods although they may substantially influence radiative heat transfer. Reference 106 indicates that surface emissivities are significantly affected by surface layers; a relationship for oxide emissivities on Zircaloy as a function of oxide thickness is provided. $\mathrm{ZrO}_{2}$ emissivities were not a strong function of temperature. Emissivities for $\mathrm{ZrO}_{2}$ formed in stean rose from 0.2 to 0.75 as the film thickened $(0.9$ to $94 \mu \mathrm{m})$.

Data cited by Burgoyne and Garlik(107) included the effects of crud. The emissivities varied from 0.75 to 0.83 as the $\mathrm{ZrO}_{2}$ film thickened from 10 to $28 \mu \mathrm{m}$. Nodular oxide had emissivities of -0.85 at thicknesses of $130 \mu \mathrm{m}$. Crudded surf aces had emissivities of 0.9 (the crud composition was not indicated) measured at temperatures from $\sim 650$ to $1150 \mathrm{~K}\left(375\right.$ to $875^{\circ} \mathrm{C}$ ). While the above data show a relatively small effect of crud on emissivity, effects of crud composition and thickness are not well-defined.

TEMPERATURE-TIME CHARACTERISTICS OF ZIRCALOY-CLAD FUEL

Zircaloy cladding has been durable in water-cooled reactors, and it has been the dominant water reactor fuel cladding material outside the USSR (a) for over $20 \mathrm{yr}$. Reactor experience has included cases where the fuel was left in the core for extended exposures; for example:

- several assemblies have remained in the Canadian Nuclear Power Demonstration (NPD) reactor since 1963

- six assemblies remained in the Shippingport reactor for $17 \mathrm{yr}$; $12.3 \mathrm{yr}$ at reactor operating conditions.

Table 14 provides a qualitative comparison of fuel assembly conditions in reactors and in dry storage. It is potentially significant that in dry storage assemblies are not subject to power ramps (which induce substantial releases of fission products) and fission product inventories are declining by radioactive decay.

(a) $\mathrm{Zr}-1 \mathrm{Nb}$ is the standard cladding material for Soviet-built reactors. 
Table 15 compares fuel assembly conditions in the reactor, wet storage, and, to the extent possible, dry storage. Reactor temperatures are higher than certain anticipated dry storage regimes but may be exceeded by the highest anticipated dry storage conditions.

Zircaloy has limitations, including the following:

- Zircaloy cladding would be completely oxidized in a few days at $\sim 80^{\circ} \mathrm{C}$ or $\sim 1 \mathrm{yr}$ at $570^{\circ} \mathrm{C}$ (see $\mathrm{Cladding} \mathrm{0xidation} \mathrm{section).}$

- In 6-month exposures at 480 to $570^{\circ} \mathrm{C}$, diffusion of oxygen into Zircaloy cladding was readily discernible and was probably a factor in cladding cracks on the inside surface when internal rod pressures caused ballooning. ${ }^{(17)}$ oxygen diffusion, however, is not expected to be a problem under nomal dry storage conditions.

- With rod pressures between 300 and $400 \mathrm{psi}$, heating to 470 to $580^{\circ} \mathrm{C}$ caused cladding to balloon (1.7 to $7 \%$ creep strain).

- Extended exposures at 480 to $570^{\circ} \mathrm{C}$ annealed radiation damage in Zircaloy cladding.

- Tests to define irradiated Zircaloy fuel rod behavior in water reactor LOCAs have indicated that cladding rupture occurs at 800 to $870^{\circ} \mathrm{C}$ for PWR rods with internal pressures of 300 to 400 psi (room temperature). Rupture properties of cladding vary from lot-to-lot. Rupture characteristics of single rods do not fully simulate rupture characteristics of rods in a fuel assembly because of rod-to-rod interactions that occur when the cladding balloons at elevated temperatures. LOCA test conditions involve heating to 800 to $900^{\circ} \mathrm{C}$ in a few seconds. Storage cask heating rates in abnomal events will be much slower, but rates and maximum temperatures remain to be def ined.

\section{DRY STORAGE OF SS-CLAD LWR FUEL}

This report centers on an assessment of dry storage behavior of Zircaloyclad fuel because Zircaloy constitutes the predominant (>95\%) U.S. LWR cladding material. Three U.S. reactors cont inue to use SS-clad fuel: Connecticut 
Yankee, San Onofre (both PWRs), and La Crosse (BWR). Some SS-clad fuel is stored at the Indian Point 1 reactor and the General Electric Co. Morris Facility in Illinois. Two foreign PWRs have SS-clad fuel: Sena (Chooz) in France and Trino in Italy. To date, none of these facilities has indicated a strong interest in dry interim storage; however, this does not rule out the prospect that the need for dry storage of SS-clad LWR fuel will develop. Therefore, this section briefly summarizes aspects of dry storage of SS-clad fuel. Some cladding failures have occurred in both BWR and PWR SS-clad fuel; $(35,51)$ therefore, as with Zircaloy-clad fuel, impacts of storing fuel with defective cladding must be assessed.

Stainless steel is generally more resistant to oxidation than Zircaloy; therefore, concerns regarding advertent or inadvertent introduction of air to a storage chamber for SS-Clad fuel will center on the oxidation of $U_{2}$ fuel exposed at potential defects and not on the degradation of the SS cladding. Fuel oxidation is considered the probable cause of primary defect propagation, leading to longitudinal splits in SS cladding during reactor expsure. (35)

Stainless steel is susceptible to SCC if three factors are present simultaneously: a sensitized metallurgical condition; a corrosive environment; and a sufficiently high stress level. While sensitization occurs in SS-clad fuel in GCRs, (108) LWR system temperatures are below the range where substantial sensitization would occur in-reactor. Sensitized stainless steel has cracked in moist air at low temperatures; ${ }^{(40)}$ however, unless severe sensitization is present, SS-clad fuel is not likely to be susceptible to cracking in air with traces of moisture. However, insof ar as severely sensitized microstructures are absent, SS-Clad fuel is not likely to be susceptible to SCC under dry storage conditions.

Fission product attack also has not emerged with SS-clad LWR fuel as it has appeared to with Zircaloy-clad fuel.

Hydrogen solubilities are much lower in stainless steel than in Zircaloy. Small amounts of residual hydrogen remaining in stainless steel are likely to be expelled to hydrogen-free cover gases in dry storage. Thus, hydrogendependent failures of stainless steel are not expected in dry storage. 
Postirradiation creep data for irradiated stainless steels suggest that creep rates are very low below $500^{\circ} \mathrm{C} .(109,110)$ Therefore, creep-related ruptures are not expected under dry storage conditions.

In summary, unless sensitized microstructures, relatively high moisture levels, and high stress levels exist simultaneously, SS-clad LWR fuel appears to have a good prospect of satisfactory performance in dry storage. Because cladding with defects may be stored, maximum acceptable temperatures for oxidation of $\mathrm{UO}_{2}$ will need to apply to both SS-clad and Zircaloy-clad fuel if the storage atmosphere includes an oxidant. 


\section{REFERENCES}

w. 


\section{REFERENCES}

1. U.S. Department of Energy. April 15, 1980. Proposed Rulemaking on the Storage and Disposal of Nuc lear Waste. DOE/NE-007, Washington, D.C.

2. Johnson, A. B., Jr. 1981. "Technical Basis for Interim Storage of Spent Nuclear Fuel." In Proceedings of Topical Meeting on Technical Bases for Nuclear Fuel Cycle Policy, Newport, Rhode Island, September 20-23, 1981.

3. Anderson, P. A., and H. S. Meyer. April 1980. Dry Storage of Spent Nuclear Fue 1. NUREG/CR-1223, Exxon Nuc lear Co., Inc., Idaho Falls, Idaho.

4. U.S. Department of Energy. November 1980. Spent Fuel Storage Alternatives. DOE-SR-0009.

5. Lawrence, M. J., G. R. Moore, and R. C. Winders. 1982. "Cost for Spent Fuel Management--An IAEA Study." Presented at International ENS/ANS Conference--New Directions in Nuclear Energy with Emphasis on Fuel Cycles, April 26-30, 1982, Brussels, Belgium. ANS Trans. 40:140-142.

6. Johnson, E. R., Associates. November 1981. A Preliminary Assessment of Alternative Dry Storage Methods for the Storage of Commercial Spent Nuclear Fuel. DOE/ET/47929-1.

7. Naqvi, S. J. 1982. "An Evaluation of the Use of Concrete Casks for Irradiated Fuel Management." Presented at the Specialist Work shop on Techniques of Dry Storage of Spent Fuel Elements, May 11-13, 1982 , Madrid, Spain. (a)

8. Tabe, T. 1982. "Status of Ury Storage of Irradiated Fuel in Canada." Presented at the Specialist Workshop on Techniques of Dry Storage of Spent Fuel Elements, May 11-13, 1982, Madrid, Spain.

9. Fleisch, J., K. Einfeld, and A. Lührmann. 1982. "Long-Term Dry Storage Demonstration with Spent LWR Fuel." Presented at the Specialist Workshop on Techniques of Dry Storage of Spent Fuel Elements, May 11-13, 1982, Madrid, Spain.

10. Schönfeld, R. 1982. "Dry Storage Concepts and Their Thermodynamic Layout." Presented at the Specialist Workshop on Techniques of Dry Storage of Spent Fuel Elements, May 11-13, 1982, Madrid, Spain.

(a) The proceedings of the Specialist Workshop on Techniques of Dry Storage of Spent Fuel Elements includes discussions that took place after the formal presentations. In some cases, the referenced information is from these discussions. 
11. Christ, R., and W. Anspack. 1982. "The TN 1300 Shipping/Storage Cask System for Spent Fue1." Presented at the Specialist Workshop on Techniques of Dry Storage of Spent Fuel Elements, May 11-13, 1982, Madrid, Spain.

12. Kaspar, G., et a1. 1982. "Dry Storage of Instrumented Bundle Experiments." Presented at the Specialist Workshop on Techniques of Dry Storage of Spent Fuel Elements, May 11-13, 1982, Madrid, Spain.

13. Bokelmann, R. F., R. R. Kühne 1, and B.J.G. Leidinger. 1982. "Economical Dry Storage of Spent Fuel and Vitrified High-Level Radioactive Waste." Presented at the Specialist Workshop on Techniques of Dry Storage of Spent Fuel Elements, May 11-13, 1982, Madrid, Spain.

14. Wright, J. B. 1981. "Spent Fuel Dry Storage--A Look at the Past, Present and Future." Presented at Fuel Cycle Conference '81, March 15-18, 1981, Los Angeles, California.

15. Gormley, 0.P. 1982. "The Role of Dry Storage as a Means to Meet National Storage Needs in the U.S.A." Presented at the Specialist Workshop on Techniques of Dry Storage of Spent Fuel Elements, May 11-13, 1982, Madrid, Spain.

16. Johnson, A. B., Jr., P. J. Pankaskie, and E. R. Gilbert. 198?. "Spent Fuel Behavior in Dry Storage." Presented at the Specialist Workshop on Techniques of Dry Storage of Spent Fuel Elements, May 11-13, 1982, Madrid, Spain.

17. Einziger, R. F., et al. April 1982. "High-Temperature Postirradiation Materials Performance of Spent Pressurized Water Reactor Fuel Rods Under Dry Storage Conditions." Nucl. Tech. 57:65-80.

18. Bolmgren, C. R. 1980. "Summary of Spent Fuel Dry Storage Testing at the E-MAD Facility." In Spent Fuel Storage Alternatives, DOE-SR-0009, pp. 257-236.

19. Wright, J. B., et a7. August 1980. Thermal Evaluation of Sealed Storage Cask Containing Spent Fue 1. AESD-TME-3050, Westinghouse Advanced Energy Systems Division, Pittsburgh, Pennsylvania.

20. Ospina, C. 1982. "Intermediate Dry Storage of the Spent Fuel of Reactor DIORIT." Presented at the Specialist Workshop on Techniques of Dry Storage of Spent Fuel Elements, May 11-13, 1982, Madrid, Spain.

21. Maxwe11, E. 0., and D. Deacon. 1982. "Operating Experience of Vault Type Dry Storage and Its Relevance to Future Storage Needs." Presented at the Specialist Workshop on Techniques of Dry Storage of Spent Fuel Elements, May 11-13, 1982, Madrid, Spain.

22. Westinghouse Advanced Energy Systems Division. August 1981. Conceptual Design and Evaluation Study for an Interim Off-Site Spent Fuel Storage Installation. WI:JBW:81-176, Pittsburgh, Pennsylvania. 
23. Doroszlai, P. 1982. "Modrex: Storage in Concrete Silos and/or Iron Casks." Presented at the Special ist Workshop on Techniques of Dry Storage of Spent Fuel Elements, May 11-13, 1982, Madrid, Spain.

24. Baxter, J. W. June 1982. "Modular Dry Storage of Spent Fue1." ANS Trans. 41:130.

25. Ohta, M. M. 1980. "Status of Dry Storage of Irradiated Fuel in Canada." In Spent Fuel Storage Alternatives, DOE-SR-0009, pp. 383-408.

26. Davidson, R., and D. Deacon. 1980. "Spent Fuel Storage." Presented at ANS/ENS International Conference, November 20, 1980, Washington, D.C.

27. Hakl, A. R. 1980. "Remote Handling Capabilities of E-MAD for Dry, Retrievable, Interim Storage of Spent Nuclear Fuel." In Spent Fuel Storage Alternatives, DOE-SR-0009, pp. 225-255.

28. McBride, J. A., et a1. 1981. "Selection of a Spent Fuel Disposal Waste Form." In Proceedings of the 1981 National Waste Terminal Storage Program Information Meeting, D0E/NWTS-15, Office of NWTS Integration, Battelle Columbus Laboratories, Columbus, Ohio, pp. 277-282.

29. Sugier, A. S., et a 1. 1982. "Le Stockage A Sec Des Combustibles Irradies Experience Francaise." Presented at the Speciali.t Workshop on Techniques of Dry Storage of Spent Fuel Elements, May 11-13, 1982, Madrid, Spain.

30. Bradley, N., and G. A. Brown. November 1981. "Natural Draught Centralized Dry Store for Irradiated Fuel and Active Waste." Nucl. Eng. Int.

31. Kärnbränslesäkerhet. 1978. Handling and Final Storage of Unreprocessed Spent Nuclear Fue 1. Vol. I and Vol. II, Stockholm, Sweden.

32. ANS Symposium. 1982. "Monitored Retrievable Storage of Spent Fuel." ANS Trans. 39:126-131.

33. Office of Nuclear Waste Management and Fuel Cycle Programs. December 1981. Monitored Retrievable Storage Concept: A Review of Its Status and Analys is of Its Impact on the Waste Management System. DOE/NE-0019, U.S. Department of Energy, Washington, D.C.

34. Bailey, W. J., and D. C. Langstaff. 1980. "Evaluation of Damage Sustained by Irradiated LWR Fuel as a Result of Handling/Transport Operations Under Essentially Normal Conditions." PATRAM 180, pp. 492-493. Compact Proceedings of the 6th International Symposium on Packaging and Transportation of Radioactive Materials, November 10-14, 1980, Berlin.

35. Pasupathi, V., and R. W. Klingensmith. November 1981. Investigation of Stainless Steel $\mathrm{Cl}$ ad Fuel Rod Failures and Fuel Performance in the Connecticut Yankee Reactor. EPRI NP-2119, Electric Power Research Insitute, Palo Alto, California. 
36. Weinhold, S. March 1982. "AVR Dry Storage Plant in Operation. Nuclear Europe, pp. 31-32.

37. Peehs, M., R. Kühnel, and G. Kaspar. 1982. "Discussion of Spent LWR Fuel Properties in Relation to Actual Long-Term Storage Concepts." Presented at the International ENS/ANS Conference on New Direction in Nuclear Energy with Emphas is on the Fuel Cycle, April 26-30, 1982, Brussels, Belgium. Summary published in ANS Trans. 40:135.

38. Unterzuber, R. September 1982. Fuel Temperature Measurements Under Imposed Dry Storage Conditions (1.4-kW PWR Spent Fuel Assembly). DOE/NV/10171-4, Westinghouse Advanced Energy Systems Division, Pittsburgh, Pennsylvania.

39. Blackburn, L. D., et al. May 1978. Maximum Allowable Temperature for Storage of Spent Nuc lear Fue 1. HEDL-TME-78-37, Hanford Engineering Development Laboratory, RichTand, Washington.

40. Long, E. L., Jr., and C. Michelson. 1964. Some Observations on The Intergranular Corrosion of Irradiated Type 304 Stainless Steel. ORNL-3684, Oak Ridge NationaT Laboratory, Oak Ridge, Tennessee.

41. U.S. Nuclear Regulatory Commission. July 1980. Control of Heavy Loads at Nuclear Power Plants. Washington, D.C.

42. Yoshimura, H. R. May 1978. "Fu11-Scale Simulation of Accidents on Spent Nuclear Fuel Shipping Systems." In Proceedings of Fifth International Symposium on Packaging and Transportation of Radioactive Materials, Las Vegas, Nevada.

43. Waddoups, I. G. September 1975. Air Drop Test of Shielded Radioactive Material Containers. SAND 75-0276, Sandia Laboratories, Albuquerque, New Mexico.

44. Bacca, J. P., et a l. 1980. "Decontamination and Refurbishment of Hot Fuel Examination Facility South (HFEF/S) Argon Cel1." In Decontamination and Decommissioning of Nuclear Facilities, ed. M. M. Osterhout, Plenum Press, New York, pp. 215-231.

45. Bohringer, I., et al. April 1982. "The Decontamination of Soft-Plated Nickel Surf aces Used in Transport and Storage Containers." ANS Trans. $40: 129$.

46. Al len, R. P. 1982. "Development of Improved Technology for Decommissioning Operations." PNL-SA-10602, to be presented at 1982 International Decommissioning Symposium, October 10-14, 1982, Seattle, Washington.

47. Bailey, W. J., et a 1. 1980-1981. Assessment of Current Onsite Inspection Techniques for Light-Water Reactor Fuel Systems. NUREG/CR-1380, PNL-3325, Vol. 1 (July 1980) and Vol. 2 (January 1981), Pac if ic Northwest Laboratory, Richland, Washington. 
48. Bel1, M. J. 1973. ORIGEN. The ORNL Isotope Generation and Depletion Code. ORNL-4628, Oak Ridge National Laboratory, Oak Ridge, Tennessee.

49. Johnson, A. B., Jr., et a1. 1980. "Significance of Shippingport and Connecticut Yankee Fuel Examinations to Extended Water Storage of LWR Fue 1." DOE-SR-0009, Proceedings of IAEA Advisory Group/Specialists Meeting, November 17-21, 1980, Las Vegas, Nevada.

50. Huebner, M. F., et a1. 1981. "HFEF Argon Ce11 Decontamination and Refurbishment." ANS Trans. 39:972.

51. Garzarolli, F., R. von Jan, and H. Stehle. 1979. "The Main Causes of Fuel Element Failure in Water-Cooled Power Reactors." Atomic Energy Review 17:31-128.

52. Boase, D. G., and T. T. Vandergraaf. 1977. "The Canadian Spent Fuel Storage Canister." Nuc1. Tech. 32:60-71.

53. Wadsten, T. 1977. "The Oxidation of Polycrystalline Uranium Dioxide in Air at Room Temperature." J. Nuc 1. Mat. 64:315.

54. Roth, R. S., T. Negas, and L. P. Cook. 1981. Phase Diagrams for Ceramists, Volume 5. American Ceramics Society.

55. Hoekstra, H. R., A. Santoro, and S. Siegel. 1961. "The Low Temperature Oxidation of $\mathrm{UO}_{2}$ and $\mathrm{U}_{4} \mathrm{Og} . " \mathrm{~J}$. Inorg. Nuc 1. Chem. 18:166-178.

56. Aronson, S., R. B. Roof, Jr., and J. Belle. 1957. "Kinetic Study of the 0xidation of Uranium Dioxide." J. Chem. Phys. 27:137-144.

57. Harrison, K. T., C. Padgett, and K. T. Scott. 1967. "The Kinetics of the Oxidation of Irradiated Uranium Dioxide Spheres in Dry Air." J. Nuc 1. Mat. 23:121-138.

58. Taylor, P., E. A. Burgess, and D. G. Owen. 1980. "An X-Ray Diffraction Study of the Formation of $\mathrm{B}-\mathrm{UO}_{2} .33$ on $\mathrm{UO}_{2}$ Pellet Surfaces in Air at 229 to $275^{\circ} \mathrm{C} . "$ J. Nuc 1. Mat. $88: 153-160$.

59. Breitung, W. 1978. "Oxygen Self and Chemical Diffusion Coefficients in $\mathrm{UO}_{2+x} \cdot "$ J. Nucl. Mat. 74:10-18.

60. Bannister, M. J. 1968. "The Storage Behavior of Uranium Dioxide Powders - Review Article." J. Nucl. Mat. 26:174-184.

61. Scott, K. T., and K. T. Harrison. 1963. "Some Studies of the Oxidation of Uranium Dioxide." J. Nucl. Mat. 8:307-319.

62. Wang, R. March 1981. Spent Fuel Special Studies Progress Report: Probable Mechanisms for 0xidation and Dissolution of Single-Crystal $0_{2}$ Surfaces. PNL-3566, Pacific Northwest Laboratory, Richland, Washington. 
63. Anderson, J. S., L.E.J. Robert S, and E. A. Harper. 1955. "The Oxides of Uranium. Part VII. The 0xidation of Uranium Dioxide." J. Chem. Soc. pp. 3946-3959.

64. Catlow, C.R.A. 1979. "Oxidation Reactions and Dopants in NonStoichiometric U02." J. Nucl. Mat. 79:432-434.

65. Dominey, D. A. 1968. "Oxidation of $\mathrm{UO}_{2}$ by $0 x y g e n$ at $66^{\circ} \mathrm{C}$ and $80^{\circ} \mathrm{C} . "$ J. Inorg. Nuc 1. Chem. 30:1757-1760.

66. Aratono, Y., and E. Tachikawa. 1978. "Release-Behavior of Tritium on Heating Irradiated $\mathrm{UO}_{2}(\mathrm{Li})$ Pellet in a resence of Oxygen." J. Inorg. Nuc 1. Chem. 40:931-935.

67. Hillner, E. 1977. "Corrosion of Zirconium-Base Alloys - An Overview." In Zirconium in the Nuclear Industry, ASTM STP 633, A. L. Lowe and G. W. Parry, eds., Amierican Society for Testing and Materials, pp. 211-235.

68. Westerman, R. E. 1964. "High-Temperature Oxidation of Zirconium and Zircaloy-2 in 0xygen and Water Vapor." J. Electrochem. Soc. 111:140-147.

69. Gulbransen, E. A., and K. F. Andrew. April 1958. "Oxidation of Zircaloy-2 and $-3 A$ at 300 to $850^{\circ} \mathrm{C}$." Trans. of Met. Soc., AIME, pp. 281-286.

70. Barner, J. 0., et al. 1982. Materials Test-2 LOCA Simulation in the NRU Reactor. NUREG/CR-2509, PNL-4155, Pacific Northwest Laboratory, Richland, Washington.

71. Mohr, C. L., and G. M. Hesson. 1982. "Ballooning and Flow Blockage for High Alpha LOCA Conditions." Presented at the IAEA Specialists Meeting on Water Reactor Fuel Element Performance Computer Modeling, March 14-19, 1982, Preston, Lancashire, England.

72. Energy Regulations, 10 CFR, Section 71, Subpart D, Appendix B, 1982 .

73. Longest, A. W., R. H. Chapman, and J. L. Crowley. June 1982. "Boundary Effects on Zirc aloy-4 Cladding Deformation in LOCA Simulation Test." ANS Trans. 41:383.

74. Vigil, M. G., H. R. Yoshimura, and A. A. Trujillo. June 1982. "An Experimental Program for Assessing the Thermal Response of a Spent Fuel Transport Cask." ANS Trans. 41:92.

75. Burman, D. C., et al. 1982. "Deformation in Severe Core Damage Accidents." Presented at the Sixth International Conference on Zirconium in the Nuclear Industry, June 28-July 1, 1982, Vancouver, British Columbia. 
76. Chapman, R. E., et al. September 1978. Ef fect of Creep Time and Heating Rate on Deformation of Zircaloy-4 Tubes Tested in Steam with Internal Heaters. NUREG/CR-0343, Oak Ridge National Laboratory, Oak Ridge, Tennessee.

77. El-Wakil, M. M. 1971. Nuclear Heat Transport. International Text Book Co., New York.

78. Howe, L. M. 1962. "Radiation Damage in Zirconium, Zircaloy-2, and 410 Stainless Stee 1." In Proceedings of the Symposium on Radiation Damage in Solids and Reactor Materials, May 7-11, 1962, Venice, Italy.

79. Lowry, L. M., et a1. Evaluating Strength and Ductility of Irradiated Zircaloy." NUREG/CR-1729, BMI-2066, Batte1le Columbus Laboratories, Columbus, Ohio.

80. Pankaskie, P. J. May 1980. Mechanistic Considerations Used in the Development of the PROFIT PCI Failure Model. NUREGTCR-1462, PNL-3386, Pacific Northwest Laboratory, Richland, Washington.

81. Pankaskie, P. J. April 1980. "Strain Energy Absorption As a Failure Index for Material Sensitive to Interstitial-Dislocation Interactions." PNL-SA-8597, Pacific Northwest Laboratory, Richland, Washington.

82. Yaggee, F. L. June 1982. "An SEM-TEM Technique for Use with Fueled LWR Cladding." ANS Trans. 41:248.

83. Cubbicciotti, D., et al. November 1976. The Nature of Fission Product Deposits Inside Light-Water Reactor Fuel Rods. EPRI RP-455-1, prepared for the Electric Power Research Institute by Stanford Research Institute, Menlo Park, California.

84. Wright, J. B., et al. September 1980. Fuel Temperature Measurements Under Impaired Dry Storage Conditions. AESD-TME-3036, Westinghouse Advanced Energy Systems Division, Pittsburgh, Pennsylvania.

85. Sherba, P. S. July 1980. "Thermal Interactions and Nominal 2 kW Drywe11 Experiments: Interim Report." WIG:JBW:80-202, West inghouse Advanced Energy Systems Division, Pittsburgh, Pennsylvania.

86. Leurdberg, W. L. September 1980. "Report of Consol idated Thermal Data." DOE/NU/00597-6.

87. Hillner, E. January 1980. Corrosion and Hydriding Performance Evaluation of Three Zircaloy-2 Clad Fuel Assemblies After Cont inuous Exposure in PWR Cores 1 and 2 at Shippingport, Pennsylvania. WAPD-TM-1412, Bett is Atomic Power Laboratory, West Mifflin, Pennsylvania.

88. Mayman, S. A. 1978. "Canadian Experience with Wet and Dry Fuel Storage Concepts." Presented at ANS Executive Conference on Spent Fuel Policy and Its Implication, April 2-5, 1978, Buford, Georgia. 
89. Fuhrman, N., et al. November 1976. Evaluation of Fuel Rod Performance in Maine Yankee Core I. EPRI NP-218, Electric Power Research Institute, Palo Alto, California.

90. Davies, J. H. June 1982. "Secondary Damage in LWR Fuel Following PCI Characteristics and Mechanisms." ANS Trans. 41:269-270.

91. Cox, B., B. A. Surette, and J. C. Wood. 1981. "Pellet-Clad Interaction Failures: Stress Corrosion Cracking by Iodine or Metal Vapour Embrittlement by Cesium/Cadmium Vapours?" In Proceedings of Second International Conference on Environmental Degradation of Engineering Materials, September 21-23, 1981, Virginia Polytechnic Institute, Blacksburg, Virginia, pp. 293-302.

92. 01 ander, D. R. June 1982. "Chemical Aspects of Pellet-Cladding Interaction in Light Water Reactor Fuel Elements." ANS Trans. 41:270.

93. Kleykamp, H. 1979. "The Chemical State of LWR High-Power Rods Under Irradiation." J. Nuc 1. Mat. 84:109-117.

94. Miller, A. K., H. Ocken, and A. Tasooji. 1981. "Iodine Stress Corrosion Cracking of Zircaloy: Laboratory Data, A Phenomenological Model, and Predictions of In-Reactor Behavior." J. Nucl. Mat. 99:254-268.

95. Yaggee, F. L., R. F. Mattas, and L. A. Neimark. 1979. Characterization of Irradiated Zircaloys: Susceptibility to Stress Corrosion Cracking.

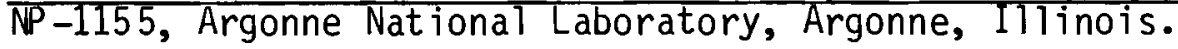

96. Yaggee, F. L., R. F. Mattas, and L. A. Neimark. 1980. Characterization of Irradiated Zircaloys: Susceptibility to Stress Corrosion Cracking. NP-1557, Argonne National Laboratory, Argonne, Illinois.

97. Miller, D. A., and T. G. Landon. 1979. "Creep Fracture Maps for 316 Stainless Steel." Met. Trans. A., AIME, 10A:1635-1641.

98. Lovell, A. J., B. A. Chin, and E. R. Gilbert. 1981. "In-Reactor Creep Rupture of $20 \%$ CW AISI 316 Stainless Steel." J. Mat. Sci. 16:870-876.

99. Sawatzky, A., and B.J.S. Wilkins. 1967. Hydrogen Solubility in Zirconium Alloys Determined By Thermal Diffusion." J. Nuc l. Mat. 22:304.

100. Sawatzky, A. January 1975. Hydrogen Distribution in a Zirconium Sheath with a Gas Plenum. AECL-4760, Whiteshell Nuclear Research Establishment, Pinewa, Manitoba, Canada.

101. Coleman, C. E. 1982. "Effect of Texture on Hydride Reorientation and Delayed Hydrogen Cracking in Cold-Worked $\mathrm{Zr}-2.5 \mathrm{Nb} . "$ In Zirconium in the Nuclear Industry, ASTM STP 754, D. G. Franklin, ed., American Society for Testing and Materials, pp. 393-411. 
102. Zima, G. E. November 1978. Comments on Crud as a Safety and Operational Factor of Independent Spent Fuel Storage Installations. NUREG/CR-0163, PNL-2657, Pacific Northwest Laboratory, Richland, Washington.

103. Blok, J. 1976. "Characterization of Corrosion Product Deposits in the BWR." In Proceedings of System Contamination Workshop, p. 81, Electric Power Research Institute, Palo Alto, California, March 15-17, 1976.

104. Rosemer, J., and M. W. Rootham. 1977. "Estimation of Activity Inventories in Primary Circuits of Pressurized Water Reactors." In Proceedings of British Nuclear Energy Society Conference, Water Chemistry of Nuclear Reactor Systems, October 24-27, 1977, Bournemouth, England.

105. Allen, R. P., H.W. Arrowsmith, and M. W. McCoy. 1981. "Decontamination of Alpha-Contaminated Materials by Electropolishing and Vibratory Finishing." In Proceedings of International Symposium of Management of AlphaContaminated Wastes, pp. 177-188.

106. Hagerman, D. L., G. A. Reymann, and R. E. Mason, compilers. August 1981. MATPRO - Version II (Rev. 2). A Handbook of Materials Properties for Use in the Analysis of LWR Fuel Behavior. NUREG/CR-0497, TREE-1280, Rev. 2, EG\&G Idaho, Inc., Idaho Falls, Idaho.

107. Burgoyne, T. B., and A. Garlik. 1976. Paper presented at $\mathrm{CD} / \mathrm{CSNI}$ Meeting on Behavior of Water Reactor Fuel Elements under Accident Cond itions, September 13-26, 1976, Spinrad, Norway.

108. Flowers, R. H. 1977. "Results of an Examination of Irradiated 0xide Fuel Following Storage in Water." Testimony presented at the windscale Inquiry on Spent Fuel Reprocessing, Windscale, United Kingdom, October 1977.

109. Gilbert, E. R., and N. E. Harding. 1969. "Comparison of In-Reactor Creep and Postirradiation Creep Tests of Structural Materials for Nuclear Application." In Irradiation Effects in Structural Alloys for Thermal and Fast Reactors, ASTM STP 457, pp. 17-37.

110. Gilbert, E. R. 1971. "In-Reactor Creep of Reactor Materials." Reactor Tech. 4:258-285. 

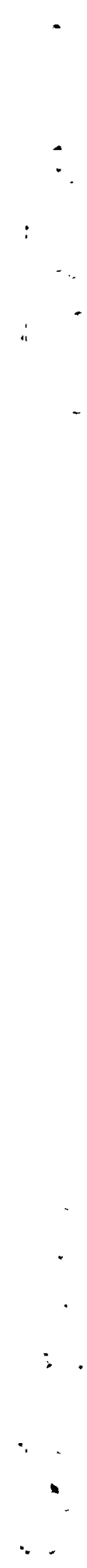


\section{APPENDIX A}

MULTIPLE TERMINOLOGIES USED IN DRY STORAGE TECHNOLOGY 


\section{MULTIPLE TERMINOLOGIES USED IN DRY STORAGE TECHNOLOGY}

The development of dry storage technology has been under way for more than two decades in several countries. Thus, it is not surprising that multiple terms have evolved for the same concept or component. This trend parallels the multiple terms that have emerged for wet storage facilities (for example, basin, p001, pond). However, some confusion is developing for dry storage terminologies due to conflicting or inadequately defined usage.

A paper presented at the Third European Nuclear Conference, Brussels, Belgium, April 1982, included recommendations for a set of terms for dry storage technologies. (A.1) Those recommendations are compared with other terms that are in use in Table A.1. Standardized usage has merits, but much literature already exists that deviates from the proposed terminology.

TABLE A.1. Parallel Terms Used for Dry Storage Technology

$\operatorname{ISFM}(\mathrm{a})$ Recommendations

Caisson Storage

- Surface storage

- Subsurface storage

- Storage in geologic formation

Cask Storage

Vault Storage

- Active cooling

- direct

- indirect

- Passive cooling

- direct

- indirect
Alternate Terms

Silo; sealed surface cask; concrete canister Near-surface dry we 11

Subsurface dry well

Metal cask; concrete cask

Canyon, bay, store, cel1

(a) International Spent Fuel Management; a study group that functions under the International Atomic Energy Agency, Vienna, Austria. 
Confusion is emerging with certain usages; for example,

- Cask storage does not differentiate between concrete and metal types; thus, the cask material should be specified.

- Storage canister is a confusing term: concrete canisters are synonymous with silos; metal canisters are containers for individual fuel assemblies. In this report the term canister refers only to metal containers.

- Rod (pin) compaction and consolidation are synonymous terms in the United States for the procedure of removing fuel rods from assembly hardware and placing them in close-packed arrays in metal canisters. In some countries, compaction is reserved for the procedure of waste volume reduction. Thus, consolidation appears to be the preferable term.

\section{REFERENCES}

A.1. Buck, C., and A. Hanson. 1982. "International Developments in Spent Fuel Storage." ANS Trans. 40:132. 


\section{APPENDIX B}

SCOPE OF DRY STORAGE DEMONSTRATIONS 
APPENDIX B

SCOPE OF DRY STORAGE DEMONSTRATIONS

Several types of irradiated nuclear fuel are in demonstration tests. All four types of dry storage--dry wells, vaults, silos, and metal casks-are represented (see Table B.1).

\section{REFERENCES}

B.1. Wright, J. B. 1981. "Spent Fuel Dry Storage--A Look at the Past, Present, and Future." Presented at the Fuel Cycle Conference '81, March 15-18, 1981, Los Angeles, California. 
TABLE B.1. Installations and Demonstration Tests for Dry Storage of Irradiated Nuclear Fuel(a)

Type of

Stor age (basalt)

Nevada Test SiteCl imax (granite)

E-MAD (soil)
E-MAD (soil) (soil)

Id aho-INEL (soil)

Available Assigned

Storage Storage

Spaces Spaces

Fuel Type/Contents

Electric

$\begin{array}{rrr}17 & 11 & \text { PWR } \\ 4 & 2 & \text { PWR } \\ 1 & 0 & \text { El }\end{array}$

$1-2$

$61 \quad 14 \quad$ LMFBR-Fermi 1

$\begin{array}{lll}861 & 47 & \text { HTGR-PB I, Core } \\ 88 & \text { LMFBR-EBR-I I }\end{array}$

621 Misc. radioactive scrap

Kansas-PSV (salt)

15

Nevada Test Site-

E-MAD

Wylfa, Wa les

Idaho-I NEL

28,800

144
40

144
636 ETR and electric heater
Electric

11 PWR

NA(b) AGR-Magnox(c)

- $\quad$ LMFBR-EBR-I I

- LMFBR-EBR-I

$445 \quad H T G R-F S V$

67 HTGR-PBI, Core

HTGR-Rover

Silo Nevada Test SiteE-MAD

Washington-Hanford

Canada-WNRE

Metal

FRG-Wuergassen

1 cask

Electric

WR-1

HPWR-CANDU

Electric

WR-1

Electric

BWR
Lachion

Washington-Hanford

Heat

Operational History

cask

Adapted from Reference $B .1$; see Glossary for definition of terms.

(b) NA = not available.

(c) Magnesium alloy cladding for gas reactor fuel; typical composition $=$ Mg-0.9A-0.0025 Be

(d) BWR assemblies; burnup $=27,000 \mathrm{MWd} / \mathrm{tU}$; $-1 \mathrm{yr}$ in wet storage. per Unit, kW
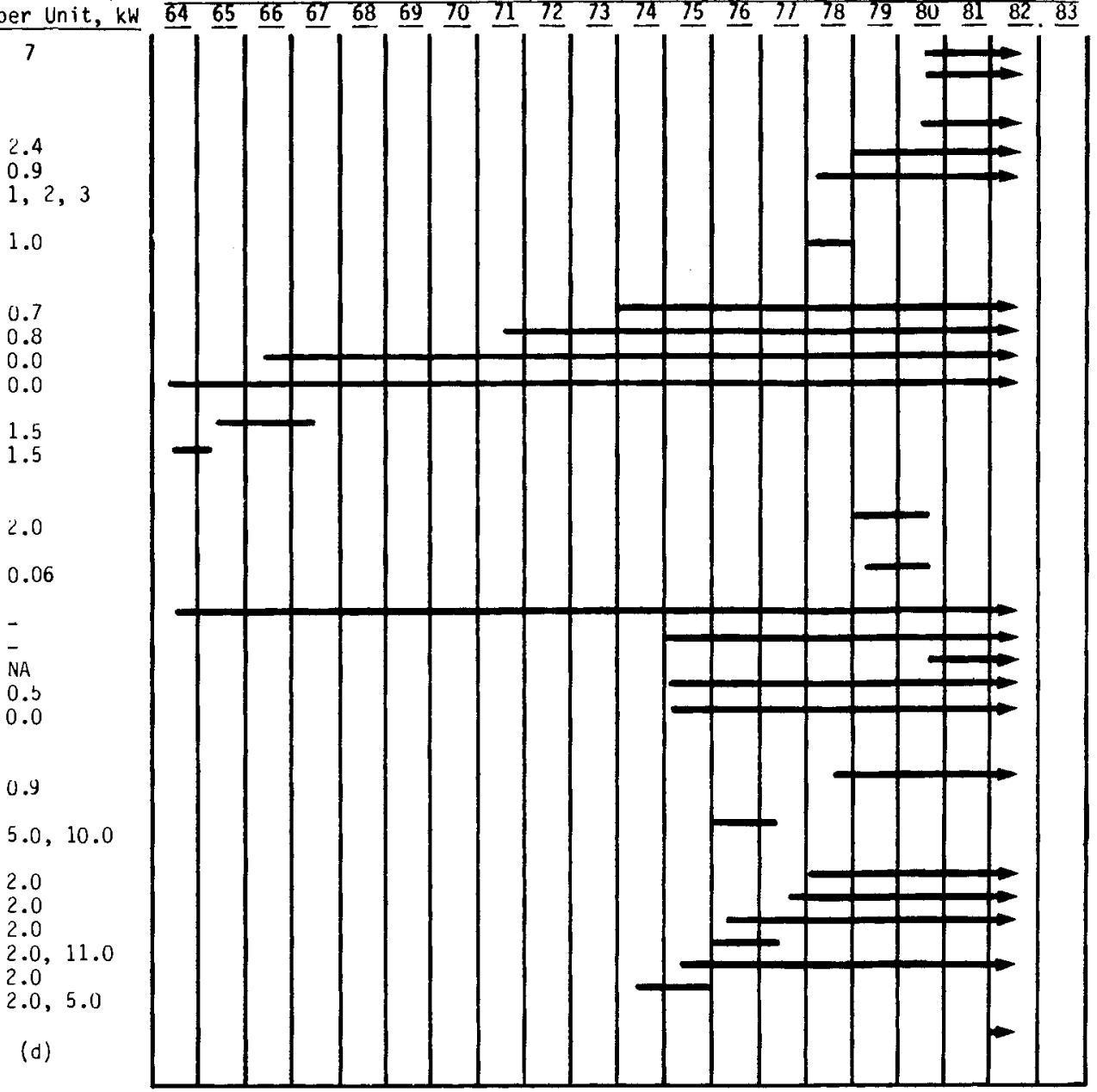

2.4

$1,2,3$

1.0

0.7

0.8

0.0

1.5
1.5

2.0

0.06

-

0.5

0.9

$5.0,10.0$

2.0

2.0

$2.0,11.0$

$2.0,5.0$

(d) 
APPENDIX C

CHARACTERISTIICS OF WATER REACTOR SPENT FUEL 
APPENDIX C

CHARACTERISTICS OF WATER REACTOR SPENT FUEL

The principal objectives of this report are to assess the current data base for dry storage of spent fuel and to project the behavior of water reactor fuel stored under dry conditions. The characteristics of spent nuclear fuel must be known to project this behavior. This appendix describes several aspects of water reactor spent fuel. Sections are presented on fuel assembly characteristics, materials, and historical aspects; fuel burnup ranges; decay heat ratings; fuel failures; crud deposits; and wet storage characteristics for the current stored inventory. Both light-water reactor (LWR) and CANDU (a) fuel types are included to assess the relevance of dry storage demonstrations for the two fuel types.

\section{FUEL ASSEMBLY PARAMETERS}

Typical geometries for a LWR fuel rod and for boiling water reactor (BWR), pressurized water reactor (PWR), and CANDU fuel assemblies are presented in Figure C.1. The LWR assemblies are much larger and have more fuel rods per assembly (bundle) than the CANDU assemblies. The characteristics of the fue 1 types are compared in Tables C.1 and C.2. LWR fuels use enriched uranium; CANDU fuels use natural uranium. Due principally to lower burnups and smaller geometries, the CANDU assemblies have lower radioactivity inventories and decay heat per assembly. Similarly, the smaller BWR assemblies have less radioactivity and heat output per assembly than PWR assemblies of similar burnup.

Irradiated PWR fuel has been placed in metal canisters and stored in dry well, vault, and silo facilities. Canistered CANDU and WR-1 fuel has also been successfully stored in silos.

(a) CANDU is only one of several types of heavy-water reactor (HWR) fuel; however, it is the only one currently being considered for dry storage. 


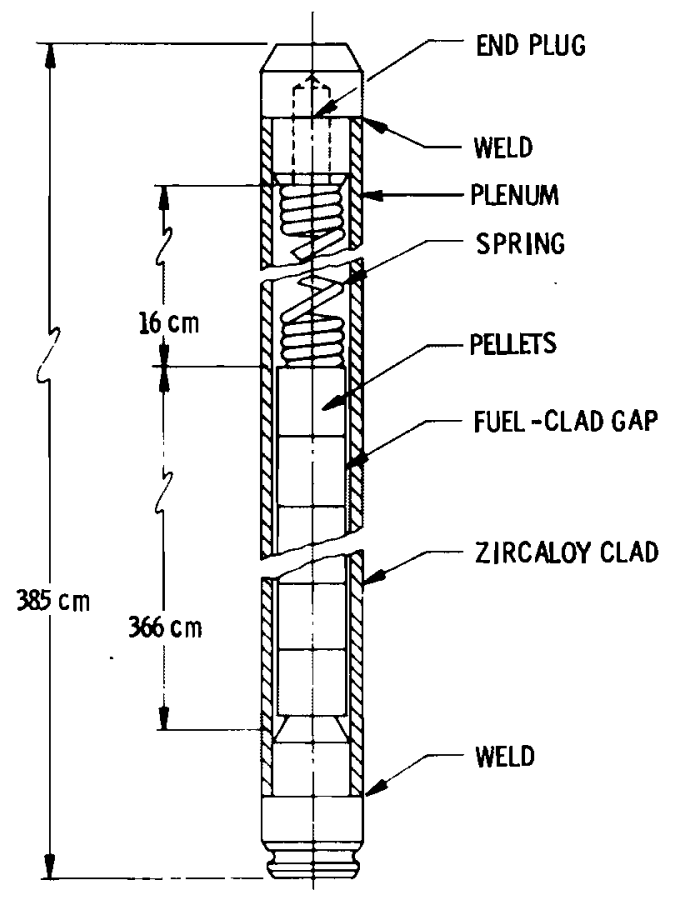

a) LWR fuel rod

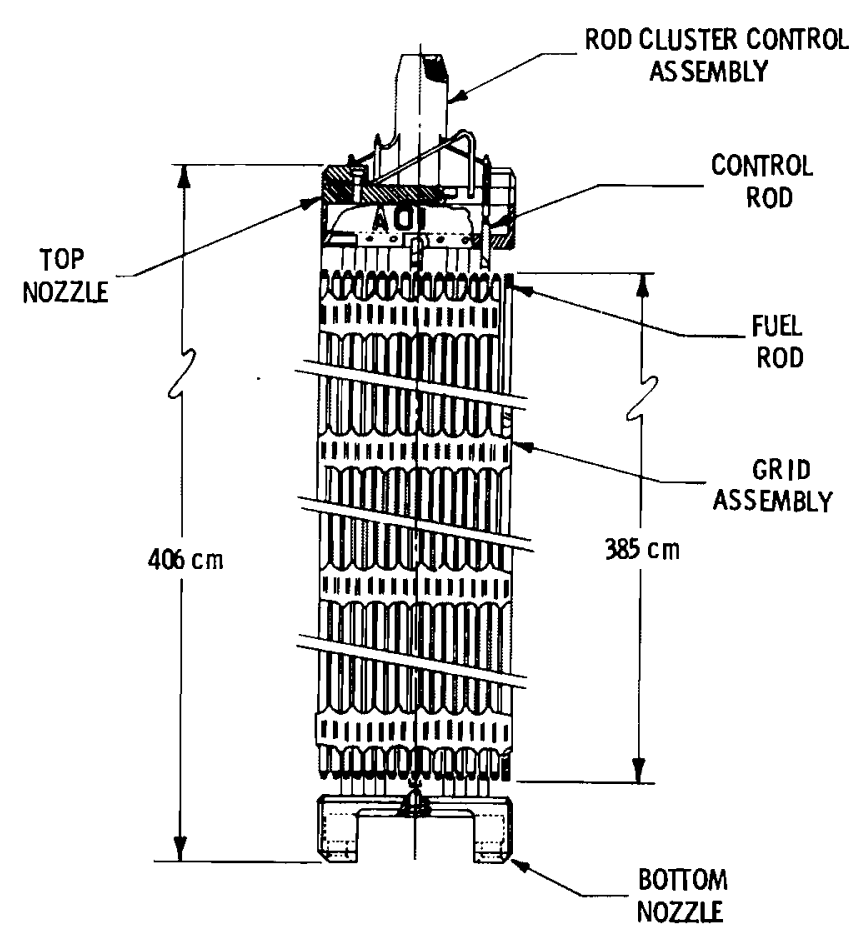

c) PWR fuel assembly

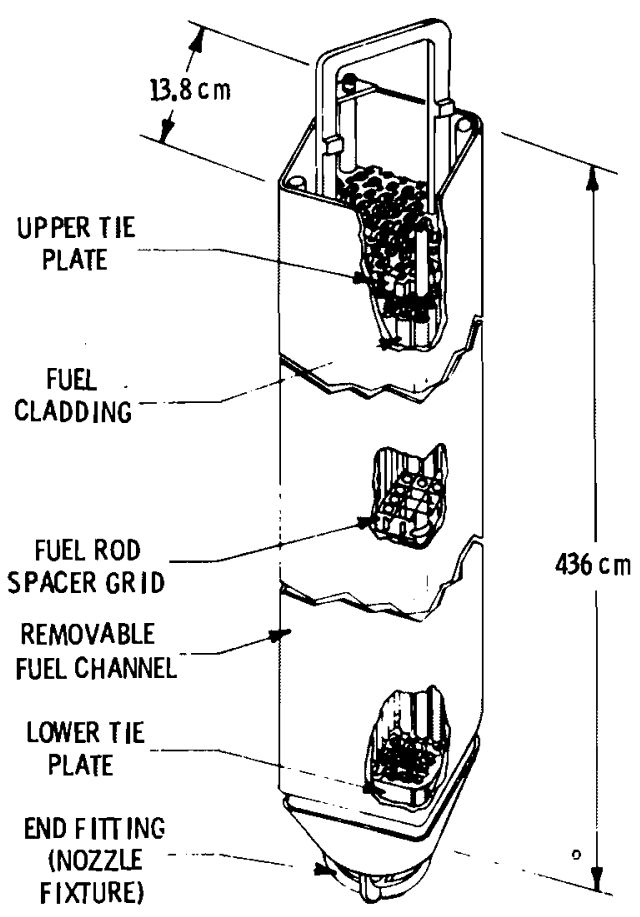

b) BWR fuel assembly

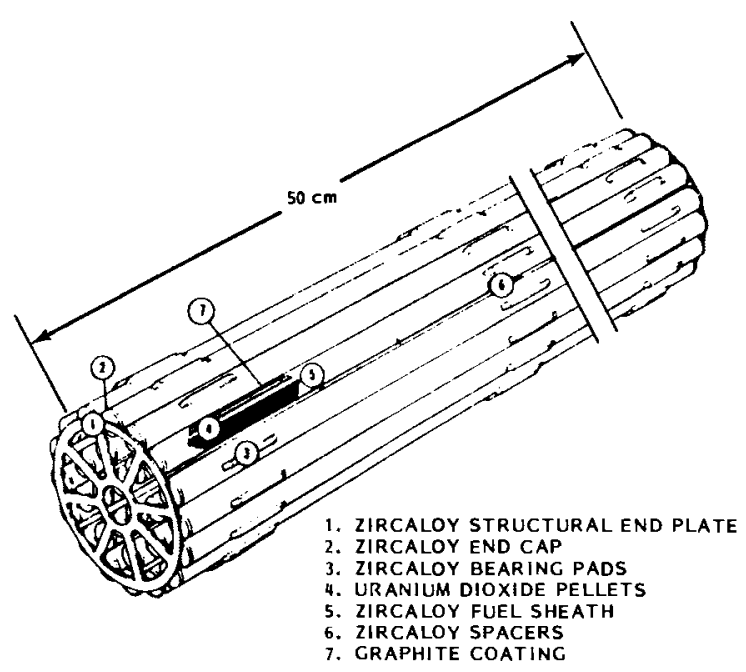

d) CANDU fuel assembly

FIGURE C.1. Typical Geometries for a LWR Fuel Rod and BWR, PWR, and CANDU Fuel Assemblies 
TABLE C.1. Major Fuel Assembly Parameters for LWR Fuel(C.1)

\begin{tabular}{|c|c|c|c|c|c|c|c|c|c|c|c|c|}
\hline VENDOR & mu & seu & $c-E$ & C-E & UEST. & MEF & MEST. & Exxon & Exxion & $\alpha$ & ef & $\boldsymbol{\alpha}$ \\
\hline FLEL ROD meraY & $15 \times 15$ & $17 \times 17$ & $14 \times 14$ & $16 \times 16$ & $14 \times 14$ & $15 \times 15$ & $17 \times 17$ & $15 \times 18$ & $8 \times 8$ & $7 \times 7$ & $8 \times 8$ & $\operatorname{exen}$ \\
\hline PLANT & $\begin{array}{l}3 \text { MILE: } \\
\text { ISLAND }\end{array}$ & FELLE- & STHCite I & AMO & $\begin{array}{l}\text { PRAIRIE } \\
\text { ISLAND } 1\end{array}$ & ZniT $_{1}$ & TROJAM & D.c. & $\begin{array}{l}\text { OYSTER } \\
\text { CFEEK }\end{array}$ & Papurs & $\begin{array}{l}\text { 2ImEeR } \\
\text { Unit } 1\end{array}$ & marct:a \\
\hline REACTOR TYPE & PUR & PUR & PUR & PUR & Pun & PUR & PUR & Pun & our & DUR & $\ln$ & an \\
\hline $\begin{array}{l}\text { PLANT COMnERECIAL } \\
\text { OPEEATIOH DATE }\end{array}$ & $12-78$ & 9-11 & $22-76$ & $8-70$ & $12-73$ & $6-73$ & $5-78$ & $8-75$ & $12-69$ & $8-74$ & 1980 & $7-78$ \\
\hline ASSERBLIES PER CORE & 177 & 205 & 217 & 177 & 121 & 193 & 193 & 183 & 560 & 264 & $\operatorname{sen}$ & 560 \\
\hline $\begin{array}{l}\text { FUEL ROD LOCATIONS } \\
\text { PER ASSEMBLYY }\end{array}$ & 225 & 290 & 190 & 256 & 106 & 225 & 289 & 2es & 64 & 48 & 64 & 64 \\
\hline $\begin{array}{l}\text { FuEL RODS } \\
\text { PER ASSEEMLLY }\end{array}$ & 208 & 264 & 176 & 236 & 179 & 204 & 264 & 204 & 60 & 49 & 63 & 62 \\
\hline 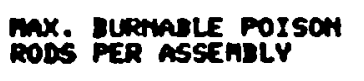 & 16 & 24 & 12 & 16 & 16 & 20 & 20 & 20 & 4 & 5 & 3 & 3 \\
\hline $\begin{array}{l}\text { EMPTY LOCATIONS } \\
\text { PER ABSEMALY }\end{array}$ & 17 & 25 & 5 & 5 & 17 & 21 & 25 & 21 & 4 & NOWE & 1 & a \\
\hline ROD PITCH & $\begin{array}{l}14.4 \\
(.568)\end{array}$ & $\begin{array}{l}12.7 \\
(.501)\end{array}$ & $\begin{array}{l}14.7 \\
(.580)\end{array}$ & $\begin{array}{l}12.8 \\
(.5 * 63)\end{array}$ & $\begin{array}{l}14.1 \\
(.556)\end{array}$ & $\begin{array}{l}14.3 \\
6.5631\end{array}$ & $\begin{array}{l}12.6 \\
(.486)\end{array}$ & $(4.533)$ & $\begin{array}{l}16.3 \\
(.642)\end{array}$ & 18.735) & $\begin{array}{l}16.3 \\
(.646)\end{array}$ & $\begin{array}{l}16.3 \\
1.6401\end{array}$ \\
\hline $\begin{array}{c}\text { SYSTEE PRESSURE } \\
\text { (PSIA) }\end{array}$ & $\begin{array}{l}15.2 \\
(2200)\end{array}$ & $\begin{array}{l}15.5 \\
(2250)\end{array}$ & $\begin{array}{l}15.5 \\
(2250)\end{array}$ & $\begin{array}{l}15.5 \\
(2250)\end{array}$ & $\begin{array}{l}15.5 \\
\text { (2250) }\end{array}$ & $\begin{array}{l}15.5 \\
(2250)\end{array}$ & $\begin{array}{l}15.5 \\
(2250)\end{array}$ & $\begin{array}{l}15.5 \\
(2250)\end{array}$ & ?:14 & ?iouss) & ?idiss) & Pio3s) \\
\hline $\begin{array}{l}\text { EOUIUALENT COOLANT } \\
\text { PASSACE DIAARETER } \\
\text { Im (INCH) }\end{array}$ & $\begin{array}{l}13.3 \\
(.525)\end{array}$ & $(11.804)$ & 13.55 & (12.47e) & $(3.511)$ & $\begin{array}{l}13.6 \\
(.534)\end{array}$ & $\begin{array}{l}11.8 \\
(.464)\end{array}$ & $\begin{array}{l}13.4 \\
(.5238)\end{array}$ & $\begin{array}{l}13.8 \\
(.545)\end{array}$ & $\begin{array}{l}17.00 \\
(.660)\end{array}$ & $\begin{array}{l}14.3 \\
(.665)\end{array}$ & $\begin{array}{l}15.2 \\
(.597)\end{array}$ \\
\hline $\begin{array}{l}\text { COOLAWT YELOCITY } \\
\text { ALOAG FUEL RODS } \\
\text { RSEEC (FT,SEC) }\end{array}$ & (i6.52) & $\left(i^{94.2)}\right.$ & (i4.2) & (is.4) & $(14.51 .8)$ & (i5.3) & (is.? & (15.5) & $\begin{array}{l}1.98 \\
(6.8)\end{array}$ & $\begin{array}{l}2.01 \\
(6.6)\end{array}$ & $\begin{array}{l}2.13 \\
(7.0)\end{array}$ & $\begin{array}{l}2.01 \\
(6.6)\end{array}$ \\
\hline $\begin{array}{l}\text { COOLANT IMLET } \\
\text { TEMERATURET } \\
\mathrm{C} \text { (F) }\end{array}$ & $\begin{array}{l}292 \\
(557.0)\end{array}$ & $300.73 .7)$ & $\begin{array}{l}284 \\
(5+4)\end{array}$ & 290 & (58) & $\begin{array}{l}274 \\
(524.8)\end{array}$ & $\begin{array}{l}289 \\
(552.5)\end{array}$ & $\begin{array}{l}278 \\
(533)\end{array}$ & 273 273.8$)$ & 275 & $\begin{array}{l}278 \\
(532.7)\end{array}$ & $\begin{array}{l}273 \\
(523.3)\end{array}$ \\
\hline $\begin{array}{l}\text { COOLAHT AXIAL CORE } \\
\text { TEMPERATIRE RISE } \\
C \text { (F) }\end{array}$ & 29.8 & $\begin{array}{l}32.8 \\
(58.3)\end{array}$ & $\begin{array}{l}31.1 \\
(56.0)\end{array}$ & $\begin{array}{l}33.6 \\
(6.5)\end{array}$ & $\begin{array}{l}36.9 \\
(66.4)\end{array}$ & $\begin{array}{l}37.1 \\
(66.8)\end{array}$ & $\begin{array}{l}37.2 \\
(66.9)\end{array}$ & $\begin{array}{l}36.5 \\
665.7)\end{array}$ & (24) & $(21)$ & (i6.1) & $\begin{array}{l}14.2 \\
(25.5)\end{array}$ \\
\hline
\end{tabular}


TABLE C.1. (contd)

\begin{tabular}{|c|c|c|c|c|c|c|c|c|c|c|c|c|}
\hline venDCR & Dat & yew & $c-\varepsilon$ & $c-E$ & UEST. & uEst. & Kest. & Exxon & ExxOH & GE & aE & os \\
\hline FUEL ROD AMRAY & $15 \times 15$ & $17 \times 17$ & $14 \times 14$ & $10 \times 16$ & $14 \times 14$ & $15 \times 15$ & $17 \times 17$ & $15 \times 15$ & $=x$ & $7 \times 7$ & exe & $\operatorname{exeR}$ \\
\hline PLWT MET QuTPUT & 800 & 1213 & 200 & 912 & sae & 1100 & 2130 & 1064 & 620 & 1067 & 810 & 788 \\
\hline 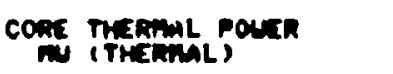 & 2772 & 3600 & 2560 & 2815 & 1650 & 3250 & 3411 & 3250 & 1930 & 3293 & 2436 & 2436 \\
\hline 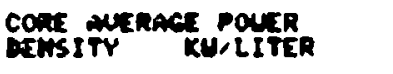 & $\infty 0.0$ & 101.6 & 78.5 & 96.4 & 95.6 & 98.1 & 104.7 & 08.1 & 40.57 & 50.732 & 50.51 & 40.15 \\
\hline 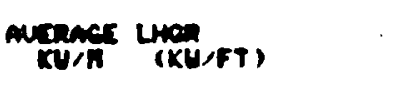 & (6e.105) & $\begin{array}{l}17.8 \\
(5.43)\end{array}$ & $20.8)$ & $\begin{array}{l}17.5 \\
(5.34)\end{array}$ & $\begin{array}{l}20.3 \\
(6.20)\end{array}$ & $\begin{array}{l}22.0 \\
(15.70)\end{array}$ & $\begin{array}{l}17.8 \\
(5.44)\end{array}$ & $22.0)$ & $\begin{array}{l}15.2 \\
14.63)\end{array}$ & $\begin{array}{l}23.2 \\
(7.040)\end{array}$ & $\begin{array}{l}17.0 \\
(5.45)\end{array}$ & $\begin{array}{l}17.7 \\
15.38)\end{array}$ \\
\hline 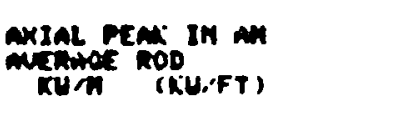 & $\begin{array}{l}24.00 \\
17.331\end{array}$ & $\begin{array}{l}21.38 \\
(6.52)\end{array}$ & $\begin{array}{l}24.00 \\
(7.31)\end{array}$ & $\begin{array}{l}21 . \infty \\
(6.41)\end{array}$ & $\begin{array}{l}24.36 \\
(7.4+1)\end{array}$ & $\begin{array}{l}26.40 \\
18.04,\end{array}$ & $\begin{array}{l}21.36 \\
16.53 .\end{array}$ & $\begin{array}{l}26.40 \\
(8.04)\end{array}$ & $\begin{array}{l}18.24 \\
(6.02)\end{array}$ & $\begin{array}{l}27.72 \\
(9.16)\end{array}$ & 21.48 & $\begin{array}{l}21.24 \\
(6.00)\end{array}$ \\
\hline 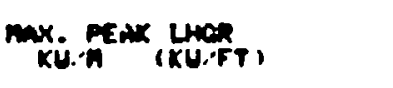 & 57.121 & $(14.7)$ & $(14.7)$ & $(14.6 .5)$ & 55.1 & $\begin{array}{l}42.3 \\
112.91\end{array}$ & 41.3 .6 & i1j.11 & 42.3 & (18.5) & $\begin{array}{l}14.0 \\
123.41\end{array}$ & $(13.4)$ \\
\hline $\begin{array}{l}\text { axIAL PEAXIMG FACTOR } \\
\text { DESIOH IMOHIMAL) }\end{array}$ & (i.2) & (i.2) & (i.56) & (i.t? & 1.72, & (i.. & ii.24 & ii.2) & $\begin{array}{l}1.57 \\
11.3 !\end{array}$ & (i.50 & $(1.3)$ & 2.56 \\
\hline $\begin{array}{l}\text { molal peaximo factor } \\
\text { DEtion imonimal }\end{array}$ & 1.5451 & 2.34 & (i.33 & (i.35) & (i.58 & $(1.55)$ & 1.55 & (i.42 & $(1.51)$ & 1.40, & 1.t+ & $(i .35)$ \\
\hline $\begin{array}{l}\text { max. Fuel TEMrenatunte } \\
\text { if! }\end{array}$ & $\begin{array}{l}2300 \\
(4170)\end{array}$ & (3670) & $\begin{array}{l}21+0 \\
(3890)\end{array}$ & $\begin{array}{l}1880 \\
3420)\end{array}$ & $\begin{array}{l}2260 \\
142001\end{array}$ & $\begin{array}{l}2340 \\
14250)\end{array}$ & $\begin{array}{l}18700 \\
134001\end{array}$ & (3005) & 2046. & $\begin{array}{l}2440 \\
(4430)\end{array}$ & 18305 & $\begin{array}{l}1890 \\
(3435)\end{array}$ \\
\hline 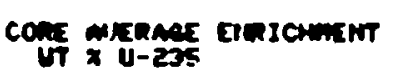 & 2.5 & 2.96 & 2.3 & 2.3 & 2.9 & 2.8 & 2.60 & 3.08 & 2.65 & 2.19 & 1.80 & 1.99 \\
\hline 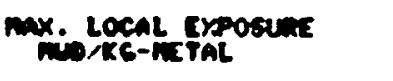 & 55 & 55 & 50 & 55 & so & 50 & so & 47.5 & 35 & 40 & 40 & 15 \\
\hline CLADDIME MiteRIAL & $21 n c-4$ & $21 n c-4$ & $21 n c-4$ & $218 C-4$ & $21 R C-4$ & $21 k r-4$ & 21 ac-4 & $218 x-4$ & $2 \sec -2$ & ZIRC-2 & $2 I R C-2$ & $22 n e-2$ \\
\hline Fut $\log _{(\text {IMCH) }}$ & i.89.13) & (ist.13) & 37.710 & 4itol.02 & (ise.36) & $3(i 48.7)$ & $(151.6)$ & (ise.e) & (i56.98) & (is1.1) & (i61.1) & (iste.4) \\
\hline 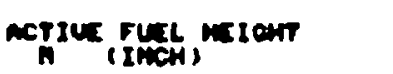 & (itis) & $\begin{array}{l}3.63 \\
(143)\end{array}$ & (ij).7) & 3i(h) & (i.66) & (it4) & (143.2) & 3itas) & (ii4) & (ic6) & $\begin{array}{l}331 \\
(i 46)\end{array}$ & 3iEt \\
\hline
\end{tabular}


TABLE C.1. (contd)

\begin{tabular}{|c|c|c|c|c|c|c|c|c|c|c|c|c|}
\hline $\begin{array}{l}\text { Uewoon } \\
\text { Fuel noo menay }\end{array}$ & $\begin{array}{l}204 \\
15 \times 15\end{array}$ & $\begin{array}{l}\text { en } \\
17 \times 17\end{array}$ & $\begin{array}{l}C-E \\
14 \times 14\end{array}$ & $\begin{array}{l}c-E \\
10 \times 16\end{array}$ & $\begin{array}{l}\text { Lest. } \\
24 \times 14\end{array}$ & $\begin{array}{l}\text { UEST. } \\
15 \times 15\end{array}$ & $\begin{array}{l}\text { vest. } \\
27 \times 17\end{array}$ & $\begin{array}{l}E \times \times 001 \\
15 \times 15\end{array}$ & $\begin{array}{l}\text { Exxor } \\
8 \times 8\end{array}$ & $x$ & ex & exem \\
\hline Loun (Emaph & (iii.e?) & (8.5) & (i.es) & iib.os & is.80) & (i.21) & P.15) & $9: 27$ & (iio.e3) & (ić.0) & (if..e) & (i6.0.0) \\
\hline 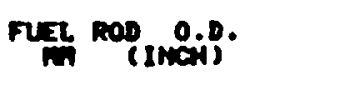 & $(.430)$ & 9.63 & 11.48, & 9:700) & (10.72a) & 10.72 & 9.5041 & $(10.774$ & $\begin{array}{l}22.74 \\
2.5015)\end{array}$ & $\begin{array}{l}24.30 \\
2.6531)\end{array}$ & $\begin{array}{l}12.52 \\
(.403)\end{array}$ & 8.27\% \\
\hline 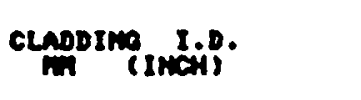 & P.:58 & $8.4338)$ & 8.86 & 8.433 & 8.4894 & 9.484 & 8.369 & 2.255 & $(0.9295)$ & (2.68) & (2.8025) & $\begin{array}{l}0.64 \\
\text { 0.610 }\end{array}$ \\
\hline 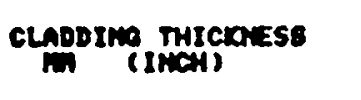 & i.67365) & i..8275) & $i .060$ & i..255) & i.6243) & i.6243) & :572 & $i .0301$ & i.014 & i.832) & $(. .034)$ & 813 \\
\hline 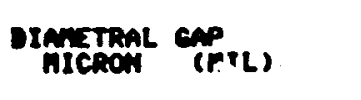 & $\begin{array}{lll}178 \\
87.01\end{array}$ & (20.3) & $\begin{array}{l}216 \\
(5.5)\end{array}$ & $\begin{array}{l}178 \\
77.01\end{array}$ & (79.5) & $\begin{array}{l}190 \\
(7.5)\end{array}$ & $\begin{array}{l}165 \\
(6.5)\end{array}$ & $(79.5)$ & 254 & (12.0) & 229.0) & 289 \\
\hline TUER MELLET PIANETER & $9.400)$ & 8.231 & $\begin{array}{l}9.64 \\
8.3795)\end{array}$ & $\begin{array}{l}8.26 \\
: .325)\end{array}$ & (..29 & 9.299 & $8: 19251$ & $\begin{array}{l}9.06 \\
2.35651\end{array}$ & $\begin{array}{l}20.66 \\
0.4195)\end{array}$ & $\begin{array}{l}12.37 \\
8.487)\end{array}$ & $\begin{array}{l}20.57 \\
8.416)\end{array}$ & \\
\hline ruEL MELET LEMTH & ??.78) & $\begin{array}{l}9.53 \\
(.375)\end{array}$ & $\begin{array}{l}16.51 \\
(.650)\end{array}$ & P.91 & $\begin{array}{l}15.24 \\
\text { (.6.6) }\end{array}$ & (15.24 & $\begin{array}{l}13.46 \\
(.530)\end{array}$ & 6.937 & : 813 & $\begin{array}{l}12.70 \\
(.506)\end{array}$ & 10.67 & 0.41 \\
\hline FUER MELLET DEMSITY & 94 & 94 & 84.75 & $\infty$ & .84 & . & 96 & 94 & 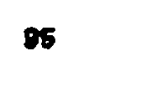 & 95 & os & \\
\hline FUEL FELLET ChaNFER & res & YES & ves & VES & no & no & no & no & ves & YES & res & \\
\hline FUEL PELLET DISH & YES & ves & YES & YES & YES & YES & YES & yES & ves & VES & no & \\
\hline Fill ans & HELIUN & KELIUN & HeLITUM & HELIUN & MELIUH & MELIUM & MELIUN & HELIUN & Melium & HELIUN & MELIUUM & \\
\hline $\begin{array}{l}\text { FLEL ROD } \\
\text { PREPRESSSLAIZATIOM }\end{array}$ & VE & VES & YE & VE & ve & $r$ & YE & YES & $m$ & no & No & \\
\hline 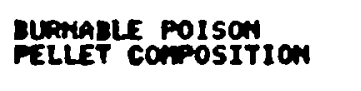 & 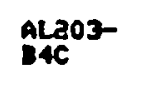 & Aleo3- & AL203- & AL203- & $\begin{array}{l}\text { S102- } \\
1203-n 20\end{array}$ & & neo & ALco3- & $\begin{array}{l}\text { yod- } \\
60203\end{array}$ & $\begin{array}{l}\text { Yod-- } \\
\text { GD203 }\end{array}$ & $\begin{array}{l}402- \\
60203\end{array}$ & \\
\hline OISON 1 & LORON & ronow & SORON & IORON & EORO & 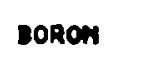 & OROM & DORON & MONE & orve & more & \\
\hline
\end{tabular}


TABLE C.2. Fuel Parameters for CANDU PHWR Fuel(C.2)

\section{Characteristics}

\section{Physical:}

Total length, mm

Pin length, mm

Cross section diameter, $\mathrm{mm}$

Total weight/assembly, $\mathrm{kg}^{(\mathrm{a})}$

HM weight/assembly, (b) $\mathrm{kg}$

Number of fue 1 rods/assembly

Pellet diameter, mm

Pellet length, mm

$\mathrm{Cl}$ add ing

Nuc lear:

Fuel type

Specific power, MW/t

Initial enrichment ( $235 \mathrm{U} / \mathrm{Pu}$ fiss)

Final enrichment

total Pu, g/kg (initial HM)

fiss. Pu, $g / k g$ (initial $/ M$ )

U-235, \%
540-MWe CANDU Reactor

\section{5}

492 to 495

81.4 to 102.5

16.6 to 24.7

13.4 to 19.8

19 to 37

12.2 to 14.3

15 to 20

Zircaloy 4

$\mathrm{UO}_{2}$

19

Natural

3.43 to 3.81

2.43 to 2.61

0.205 to 0.282

(a) Range of existing reactors; for comparison BWR weights are 250 to $307 \mathrm{~kg}$ and PWR weights are 480 to $840 \mathrm{~kg}$.

(b) Range of existing reactors; for comparison BWR weights are 172 to $194 \mathrm{~kg}$ and PWR weights are 122 to $584 \mathrm{~kg}$. 
Fuel geometries have changed somewhat with time (see Table C.1); for example, the number of rods in LWR and CANDU assemblies has increased with succeeding fuel models. When designing dry storage facilities, it is important to recognize that fuel assembly lengths and cross sections differ within each fuel type. For example, a storage cask designed for specific PWR fuel may not accomodate BWR fuel, which generally tends to be longer (see Table C.1).

LWR fuel is produced by several vendors, fuel assembly designs vary somewhat from vendor to vendor, and fue 1 handling equipment requirements differ somewhat for the various fuel designs. Fuel handling studies at the Barnwell plant have addressed special requirements for assemblies from various vendors.

\section{FUEL ASSEMBLY MATERIALS}

Materials used in water reactor fuel assemblies are summarized in Table C.3. Although both stainless steel (SS) and Zircaloy(a) are used for LWR fuel rod cladding, Zircaloy is the predominant cladding material (see Fue 1 Inventory section). Fuel rod spacer materials in LWR assemblies have changed over the years. Early assemblies used SS or Inconel spacers; some of the more recent designs have used Zircaloy spacers. End fittings for LWR assemblies have consistently been fabricated from stainless steel. The only materials used in CANDU assemblies are Zircaloy, uranium oxide, and a beryllium braze used to attach wear pads to selected fuel rods.

Early BWR fuel cladding was fabricated from stainless steel, but a stress corrosion cracking (SCC) phenomenon prompted most BWRs to change to Zircaloy cladding. Only one BWR (La Crosse) cont inues to use SS-clad fuel. Four U.S. and two foreign PWRs have operated with SS-clad fuel, and two U.S. and two foreign PWRs continue to use SS-clad fuel.

(a) BWR fuel cladding is Zircaloy-2 ( $\mathrm{Zr}-1.5 \mathrm{Sn}-0.15 \mathrm{Fe}-0.10 \mathrm{Cr}-0.05 \mathrm{Ni}$, balance $\mathrm{Zr}$ ); PWR and PHWR fuel cladding is Zircaloy-4 ( $\mathrm{Zr}-1.5 \mathrm{Sn}-0.2 \mathrm{Fe}-0.10$ $\mathrm{Cr}-0.005 \mathrm{Ni}$, balance $\mathrm{Zr}$ ). 
TABLE C.3. Fuel Bundle Materials(a)(C.3)

\begin{tabular}{|c|c|c|c|}
\hline Component & Subcomponents & Material & Alloy \\
\hline Fuel rods: & -- & $\begin{array}{l}\overline{\text { Zircaloy }(\mathrm{b})} \\
\text { Stainless steel }\end{array}$ & $\begin{array}{l}\text { Zircaloy-2 (BWR) } \\
\text { Zircaloy-4 (PWR) } \\
304 \\
348 \mathrm{H}\end{array}$ \\
\hline Fuel spacers: & $\begin{array}{l}\text { Grid } \\
\text { Springs }\end{array}$ & $\begin{array}{l}\text { Stainless steel } \\
\text { Inconel } \\
\text { Zircaloy } \\
\text { Inconel }\end{array}$ & $\begin{array}{l}304 \\
718 \\
\text { Zircaloy-4 } \\
718\end{array}$ \\
\hline Upper tie plates: & $\begin{array}{l}\text { Bail/tie plate } \\
\text { Bolts/nuts } \\
\text { Springs }\end{array}$ & $\begin{array}{l}\text { Stainless stee 1 } \\
\text { Stainless steel } \\
\text { Inconel } \\
\text { Inconel }\end{array}$ & $\begin{array}{l}304 \\
304 \\
600 \\
718\end{array}$ \\
\hline Lower tie plates: & Tie plate/nozzle & Stainless steel & 304 \\
\hline Tie rods or guide tubes: & & $\begin{array}{l}\text { Zircaloy } \\
\text { Stainless steel }\end{array}$ & -- \\
\hline \multicolumn{4}{|c|}{$\begin{array}{l}\text { (a) Some variations on material and alloy specifications may occur. } \\
\text { (b) Both Zircaloy-2 and Zircaloy-4 have been used for cladding in Canadian } \\
\text { water-cooled reactors. Zircaloy is the only material used in PHWR fuel } \\
\text { bundles except for small amounts of beryllium used to braze the appendages }\end{array}$} \\
\hline H ISTORICAL ASPECTS OF & REACTOR FUEL & & \\
\hline
\end{tabular}

The first commercial water-cooled U.S. reactors were Shippingport (PWR), which began operation in 1957, and Dresden I (BWR), which began operation in 1959. The first Canadian power reactor, the Nuclear Power Demonstration (NPD) reactor (PHNR), came on line in 1963.

Spent U.S. LWR fuel was reprocessed at the Nuclear Fuel Services (NFS) plant in West Valley, New York, from 1967 to 1971 (see Water Reactor Spent Fue 1 Inventories section). Some fuel from the Shippingport reactor has remained in water storage since 1959; however, most of the U.S. LWR inventory has deve 1oped since the NFS plant ceased operation in 1971.

Canadian PHWR fuel has remained in water storage since 1963. A small fraction of the CANDU fuel was sent to England for reprocessing; but the remainder is stored in water pools, except for $\sim 360$ Douglas Point reactor

\section{C.8}


assemblies that are in a dry storage demonstration at the Whiteshe 11 Nuclear Research Establishment (WNRE) (see Appendix B). This dry storage demonstration program also includes $\mathrm{Zr}-2.5 \mathrm{Nb}-\mathrm{c}$ lad fuel from the organic-cooled WR-1 reactor. WR-1 assemblies are now being stored routinely in licensed silos after 18 months of licensed wet storage.

Significant to dry storage technology is the fact that a major fraction of the current U.S. and Canadian spent fuel inventories have been in wet storage for over $5 \mathrm{yr}$. Thus, decay heat levels are relatively low (see Fuel Ages and Decay Heats section). Much of the older fuel from European and Japanese reactors has been shipped to reprocessing plants.

A small fraction of fuel rods develop defects during reactor exposure. The types of defects and potential impacts in dry storage are discussed in the Fuel Failure section. Several cladding failure mechanisms have developed during the course of power reactor operations. Most of the failure mechanisms have been identified and eliminated. Fuel destined for dry storage could include rods with various types of cladding defects. Methods to ident ify failed fuel rods are discussed in the body of the report.

\section{FUEL BURNUP RANGES}

The term burnup describes the process by which fissionable atoms in the $\mathrm{UO}_{2}$ fuel are converted to fission products and energy. The unit used for burnup in this report is megawatt-days per tonne of uranium (MWd/tU). Burnups for Canadian fuel are often expressed as MWd $/ \mathrm{kgU}$. The SI burnup unit is gigajoule/kgU, and the conversion is expressed by: [MWd/tU] [0.0864] $=\mathrm{GJ} / \mathrm{kgU}$. The range of goal burnups for the current generation of fuel is:

- $\mathrm{PWR}=26$ to $34 \mathrm{MWd} / \mathrm{tU}$

- $B W R=28$ to $30 \mathrm{MWd} / \mathrm{tU}$

- CANDU $=6.5$ to $8 \mathrm{MWd} / \mathrm{tU}$.

A burnup assessment for U.S. LWR fue ${ }^{(C .4)}$ indicated that average burnups have increased over the course of power reactor operation. Thus, older spent fuel has not only cooled longer but also began cooling from a lower heat level. 
An important consideration for dry storage is that burnup and time since reactor discharge are the principal determinants of spent fuel decay heats. Decay heats decrease with decreasing burnup and with increasing storage time as shown in Figure 15 in the text.

Several demonstration programs are under way to assess extending current fuel burnup goals to achieve better uranium utilization. A few PWR demonstration assemblies are reaching burnups of 45,000 to 55,000 MWd/tU. An earlier demonstration assembly that was exposed in the Zorita reactor successfully reached an assembly average burnup of $\sim 57,000 \mathrm{MWd} / \mathrm{tU}$. (C.5) Rods from this assembly (burnups up to $62,000 \mathrm{MWd} / \mathrm{tU}$ ) are in dry storage at Junta de Engeria Nuclear in Madrid, Spain.

High-burnup assemblies are not likely to be a significant consideration in dry storage technology in the near term. Even if the demonstrations lead to a favorable decision to institute extended burnup on a large scale, it is probable that a decade or more would be required to develop substantial stored inventories of high-burnup fuel, including fabrication, irradiation, and cooling to a level compatible with dry storage.

DECAY HEAT RATINGS AND RADI ATION INVENTORIES

The relationship of decay heat to burnup and time is shown in text Figure 15 for BWR and PWR fuel. Text Figure 10 summarizes an estimate of heat ratings for the U.S. LWR inventory, indexed to 1986. Decay heat ratings and radiation levels as a function of time are given in Table C.4. Detailed summaries of radioactive species in LWR fuel are given in Reference C.6 and Appendix D.

\section{FUEL FAILURES}

Several fuel failure mechanisms have occurred during water reactor operations. Table C.5 summarizes the principal failure mechanisms and characteristics and the approximate time frame when they were most active.

When fuel cladding perforates in the reactor, mobile fission gases are released to the reactor coolant. The most common initial cladding defects are a pinhole or small crack. If the defect is large enough to permit entry of 
TABLE C.4. Comparison of LWR and CANDU Decay Heat and Radioactivity(C.2)

\begin{tabular}{|c|c|c|c|}
\hline & $\begin{array}{c}\text { PWR } \\
(1000 \text { MWe) }\end{array}$ & $\begin{array}{c}\text { BWR } \\
(1000 \mathrm{MWe})\end{array}$ & $\begin{array}{c}\text { CANDU } \\
(540 \text { MWe })\end{array}$ \\
\hline \multicolumn{4}{|c|}{ Total activity, $\mathrm{C} \mathbf{i} / \mathrm{kg}$} \\
\hline After 150 days & $4.6 \times 10^{3(a)}$ & $3.8 \times 10^{3(b)}$ & \\
\hline After $1 \mathrm{yr}$ & $2.3 \times 10^{3(a)}$ & $1.9 \times 10^{3(b)}$ & $7.9 \times 10^{2(c)}$ \\
\hline After $10 \mathrm{yr}$ & $3.2 \times 10^{2(a)}$ & $2.9 \times 10^{2(b)}$ & $8.4 \times 10^{1(c)}$ \\
\hline
\end{tabular}

Decay heat, $\mathrm{W} / \mathrm{kg}$

After 150 days

$24.3^{(a)}$

$18.7^{(b)}$

After $1 \mathrm{yr}$

$10.4^{(a)}$

$8.2^{(b)}$

After $10 \mathrm{yr}$

$2.3^{(a)}$

$2.2^{(b)}$

$3.15^{(c)}$

$0.22^{(c)}$

(a) Burnup $=32,200 \mathrm{MWd} / \mathrm{tU}$.

(b) Burnup $=30,000 \mathrm{MWd} / \mathrm{tU}$.

(c) Burnup $=7,500 \mathrm{Mwd} / \mathrm{tU}$.

reactor coolant, secondary effects may cause enlargement of the original hole. Therefore, a fraction of the cladding perforations lead to defects that allow an area of uranium oxide fuel pellet to be visible through the cladding perforation.

Frequently the cladding defects are not obvious by visual inspection of the assembly either because they are too small or because they are located on fuel rod surfaces that are not easily visible. In-reactor fuel failure events are detected by fission product activities in the reactor coolant or off gas from the coolant. The numbers of fuel rod failures are estimated by the levels of reactor coolant fission product activities, but not with high accuracy. If reactor coolant fission product activities indicate that cladding failures have occurred in a given batch of fuel, the fuel assemblies may be inspected in the reactor pool to investigate the type and incidence of failures.

Estimates have been published of the number of fuel rod failures for $L_{W R}(C .7)$ and $C_{A N D U}(C .7, C .8)$ fuel. Failure rates were higher for earlier 
TABLE C.5. Types and Characteristics of Fuel Failures in water Reactor Fue 1

\begin{tabular}{|c|c|c|c|c|c|c|}
\hline $\begin{array}{l}\text { Type of } \\
\text { Fue 1 } \\
\end{array}$ & $\begin{array}{c}\text { Fuel } \\
\text { Cladding } \\
\end{array}$ & Fai lure Mechanism & Cause & Defect Description (a) & Corrective Action & Time Frame(b) \\
\hline \multirow[t]{6}{*}{ BWR } & Zircaloy & Crud-induced & $\begin{array}{l}\text { Copper-rich crud } \\
\text { deposit }\end{array}$ & Areas of exposed $\mathrm{UO}_{2}$ & Remove $\mathrm{Cu} \mathrm{HtEx}$ & $1965-1970$ \\
\hline & Zircaloy & Hydriding & $\mathrm{H}_{2} \mathrm{O}$ in fuel & Cracks and blisters & Lower fuel $\mathrm{H}_{2} \mathrm{O}$ limits & $1962-1975$ \\
\hline & Zircaloy & Fretting & $\begin{array}{l}\text { Mechanical } \\
\text { abrasion }\end{array}$ & $\begin{array}{l}\text { Small wear hole through } \\
\text { cladding wall }\end{array}$ & $\begin{array}{l}\text { Power ramping restric- } \\
\text { tions }\end{array}$ & $1960-1970$ \\
\hline & Zircaloy & PCI & $\begin{array}{l}\text { Power ramping; } \\
\text { fission product } \\
\text { action }\end{array}$ & $\begin{array}{l}\text { Pinholes and axial } \\
\text { cracks }\end{array}$ & $\begin{array}{l}\text { Advanced designs being } \\
\text { tested }\end{array}$ & 1972-present \\
\hline & Zircaloy & $\begin{array}{l}\text { Manuf ac turing } \\
\text { defects }\end{array}$ & $\begin{array}{l}\text { Manuf acturing } \\
\text { errors }\end{array}$ & Various & Better QC & 1960-present \\
\hline & $\begin{array}{l}\text { Stainless } \\
\text { steel }\end{array}$ & SCC & $\begin{array}{l}\text { Cladding stress } \\
\text { and } \mathrm{O}_{2} \text { in } \\
\text { coolant }\end{array}$ & Large cracks & $\begin{array}{l}\text { Replace SS with Zircaloy } \\
\text { cladding }\end{array}$ & $\begin{array}{l}1960-1963 \\
1978-\text { present }\end{array}$ \\
\hline \multirow[t]{7}{*}{ PWR } & Zircaloy & Hydriding & $\mathrm{H}_{2} \mathrm{O}$ in fuel & Cracks and blisters & & $1962-1972$ \\
\hline & Zircaloy & Cladding Collapse & $\begin{array}{l}\text { Fuel } \\
\text { densification }\end{array}$ & $\begin{array}{l}\text { Cladding cracks at } \\
\text { collapsed areas }\end{array}$ & $\begin{array}{l}\text { Prepresssurize; } \\
\text { control U0 } 0_{2} \text { densities; } \\
\text { revised pellet shape }\end{array}$ & $1970-1973$ \\
\hline & Zircaloy & Fretting & $\begin{array}{l}\text { Foreign particles } \\
\text { or vibration }\end{array}$ & $\mathrm{Cl}$ adding perforation & $\begin{array}{l}\text { Eliminate particles or } \\
\text { redesign }\end{array}$ & $1971-1977$ \\
\hline & Zircaloy & PCI & Power ramping & $\begin{array}{l}\text { Pinholes and axial } \\
\text { cracks }\end{array}$ & $\begin{array}{l}\text { Power ramping } \\
\text { restrictions }\end{array}$ & 1974-present \\
\hline & Zircaloy & Rod bowing & Design deficiency & - & Redesign & $1968-1972$ \\
\hline & Zircaloy & $\begin{array}{l}\text { Manuf acturing } \\
\text { defects }\end{array}$ & $\begin{array}{l}\text { Manuf acturing } \\
\text { errors }\end{array}$ & Various & Better QC & 1960-present \\
\hline & $\begin{array}{l}\text { Stainless } \\
\text { steel }\end{array}$ & SCC & Fuel chips & $\begin{array}{l}\text { Large long itudindal } \\
\text { cracks }\end{array}$ & $\begin{array}{l}\text { Control generation of } \\
\text { fuel chips; increase } \\
\text { fuel/cladding gap }\end{array}$ & $1977-1978$ \\
\hline \multirow[t]{3}{*}{ CANDU } & Zircaloy & Fretting & Loose debris & Small holes in cladding & - & $1970-1972$ \\
\hline & Zircaloy & PCI & $\begin{array}{l}\text { On-line refuel- } \\
\text { ing power } \\
\text { changes }\end{array}$ & $\begin{array}{l}\text { Pinholes and axial } \\
\text { cracks }\end{array}$ & $\begin{array}{l}\text { Graphite coating and } \\
\text { fuel-to-cladding inter- } \\
\text { facial lubricant }\end{array}$ & -1970-present \\
\hline & Zircaloy & $\begin{array}{l}\text { Manuf acturing } \\
\text { defects }\end{array}$ & $\begin{array}{l}\text { Manuf acturing } \\
\text { errors }\end{array}$ & & Better QC & 1963-present \\
\hline
\end{tabular}

(a) Primary failure appearance may be obscured by secondary failure mechanisms.

(b) Indicated time frames are rough approximations. Some mechanisms reappear occasionally, and some failures occur that are not readily categorized. 
generations of LWR fuel. The in-reactor failures represent a small fraction of total rods. However, the fraction of assemblies having one or more defective rods is considerably higher than the fraction of defective rods.

Detection of Defects and Incipient Defects

Not all of the current inventory of spent unreprocessed fuel rods contain volatile radionuclides; most of the fuel rods that failed during prior duty are characterized by at least partial loss of volatile radionuclides. In cases where the cladding breach is very smal1, oxidation of the fuel and/or cladding sometimes effectively plugs the breach after some or all of the volatile fission products had been released from the fuel rod. In some and perhaps all failed fuel rods, it is expected that water (1 iquid and/or vapor) will have displaced the volatile radionuclides during the fuel duty cycle or subsequently in interim pool storage. The loss of particulate radionuclides through the cladding breach is generally believed to be minor, except in a relatively small number of cases where the hole in the cladding is large enough for fuel to be removed by the reactor coolant.

Fuel rod failures occur during the fuel duty cycle, but no known LWR or HWR fuel failures have occurred in interim pool storage. Failure statistics for LWR and HWR fuel have been summarized in Reference C.7.

There are several constraints on the operations that lead to the detec$t$ ion of failed fuel assemblies. Examinations for failed fuel assemblies (see Table C.6) are normally done in spent fuel storage pools during outages or reactor operation, and some inspections are performed in-core. ${ }^{(C .9)}$ The techniques that are employed include: visual (V), gamma scanning ( $r$ ), sipping $(S)$, mensural $(M)$, eddy current $(E C)$, and ultrasonic (U).

Whether or not failed fuel is detected can depend on how thoroughly the fuel is inspected and on the capability of the inspection technique being used. It can also depend on the time the inspection takes place. Small holes can be plugged during extended storage, and radioactive inventories diminish. Control over the quality of each technique is neither systematic nor uniform. There is limited calibration both among techniques at the same site and between the same technique at different sites, but there is no calibration to a consensus standard. The threshold for what constitutes abnormal degradation does not have a uniform definition. 
TABLE C.6. Fuel Performance Parameters Observable by Poolside Inspection Techniques

\begin{tabular}{|c|c|}
\hline Fuel Rod Parameter & Inspection Technique \\
\hline Corrosion variations & $E C, M, U, V$ \\
\hline $\mathrm{Cladding} \mathrm{degradation}$ & $E C, M, U, V$ \\
\hline Fretting wear & $E C, M, V$ \\
\hline Fuel-to-c ladd ing-bend ing & $u$ \\
\hline Hydriding & $E C, U, V$ \\
\hline Incipient defects & $E C, U$ \\
\hline Integrity & $E C, U, V$ \\
\hline
\end{tabular}

Detailed poolside inspection is not considered necessary during an outage if the reactor operation was normal, i.e., the coolant radioactivity was low. Onsite, quantitative detailed inspections of irradiated fuel are not routine. They can only be performed by each fuel vendor at a few plants per year and are expensive in terms of dollars and personnel. Most utilities do not have the expertise or hardware for detailed poolside fuel inspections. Some spent fuel storage pools lack available space for detailed inspection techniques. It is possible to overlook some failed fuel bundles with defective fuel rods if the inspection is based only on sipping of assemblies or only on visual inspection (the most common methods). Procedures for detecting failed fue 1 rods using either or both eddy-current and ultrasonic testing are being developed. The procedure for detecting incipient cladding defects is not yet developed although ultrasonic inspections of fuel rods in hot cells have shown the potential to detect incipient defects that are less than $10 \%$ of the cladding wall thickness.

There has been progress in identifying and correcting the cause, source, and origin of some fuel rod failures. The current operating emphasis, however, has changed to a once-through duty cycle and economics favor an extension of the duty cycle. With only limited experience with extended duty cycles, it seems prudent to anticipate that fuel rod failures will continue to occur within the foreseeable future. 


\section{CRUD DEPOSITS ON WATER REACTOR FUEL}

The relation of fuel crud to the underlying oxide and cladding is shown schematically in Figure C.2. The crud layer arises from deposition of corrosion products from the reactor circuit materials that circulate in the reactor coolant. A fraction of the oxides that form on reactor piping, pressure vessel, steam generation, etc., enters the reactor coolant either by dissolution or spallation. The circuit materials are principally iron-base or nickel-base alloys. Crud compositions and inventories vary for BWRs, PWRs, and PHWRs

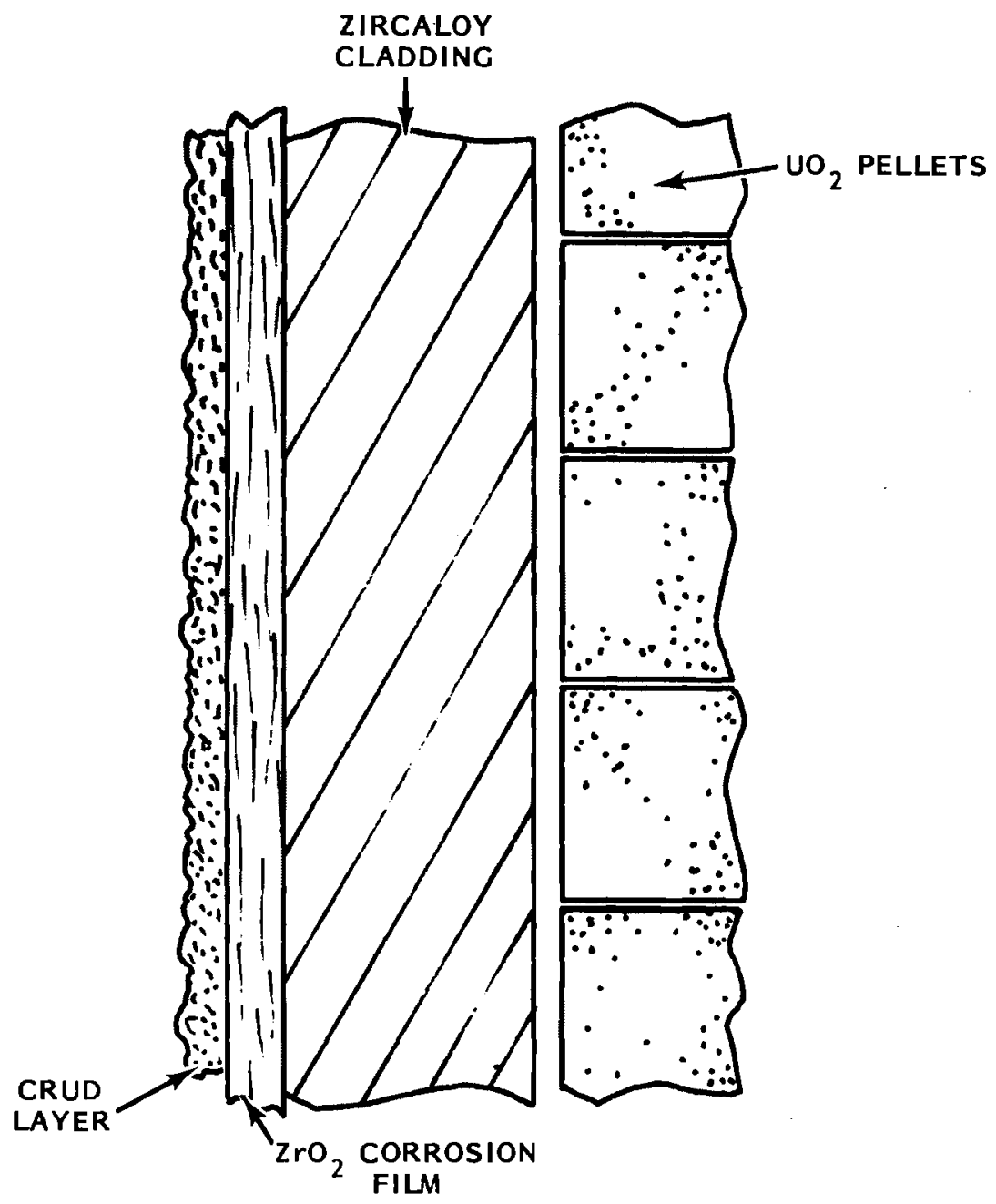

FIGURE C.2. Relationship of Fuel Crud Layer to Fuel Cladding and Fuel Cladding 0xide 
because coolant chemistries and circuit materials vary for the reactor types. Reference C.10 summarizes fuel crud types and inventories for various reactor types.

\section{WATER REACTOR SPENT FUEL INVENTORIES}

The inventory of U.S. spent LWR fuel in storage reached approximately 25,775 assemblies in 1980: 16,585 BWR and $\sim 9,190$ PWR. (C.11) The number of CANDU assemblies (bundles) in Canadian pools was 271,000 in 1982. As indicated earlier, the U.S. inventory has accumulated principally since the NFS reprocessing plant shut down in 1971 although some U.S. Zircaloy-clad fuel has been stored since 1959. The Canadian inventory has developed since 1963. Because wet storage of water reactor fuel has been successful, there is no urgent technical incentive to transfer fuel from wet to dry storage. However, there appear to be technical and economic advantages to dry storage. (C.12)

The U.S. commercial spent fuel inventory is stored at the following facilities:

\section{AFR Pools:}

West Valley, New York

Morris, Illinois

$$
\text { Approximate No. of Assemblies }{ }^{(a)}
$$

AR Pools:

71 reactors

$$
\begin{array}{ll}
750^{(b)} & (515 \text { BWR, } 235 \text { PWR }) \\
815^{(c)} & (515 \text { BWR, 300 PWR })
\end{array}
$$
(a) At the end of 1980.(C.11)
(b) All Zircaloy-clad.
(c) Zircaloy-2, Zircaloy-4, and SS-c lad.

The Canadian inventory is also stored principally in at-reactor pools; a sma11 fraction of the fuel is stored at Atomic Energy of Canada Ltd. (AECL) facilities. 


\section{FUEL ROD GAS PRESSURES}

Typically, LWR fuel rods have a plenum region located at the top of the rod (Figure C.1). As-fabricated fuel rods also have a $g$ ap between the fuel pellets and the cladding. The fuel pellets also have some porosity (generally 5 to $7.5 \%)$.

In early LWR fuel rod fabrication, the free volumes were filled with helium at a pressure of approximately $1 \mathrm{~atm}(0.098 \mathrm{MPa})$. When fuel densification phenomena developed, the fill gas pressures for PWR rods were increased to counter the reactor coolant system pressures, which tended to force the cladding against the fuel pellets. PWR system pressures ( 2000 psi) are higher than BWR pressures ( 1000 ps $i)$; fill gas pressures are also typically higher for PWR fuel rods. PWR rods are pressurized to suppress cladding creepdown onto the fue 1; BWR pressurization is intended principally to improve thermal conductivity; and CANDU fuel is not prepressurized but develops fission gas pressures during reactor operation.

Gaseous fission products are generated in the fuel during reactor operation. A fraction of the gas is released while the fuel is at operating temperatures. Krypton-85 is the principal long-lived gaseous fission product.

\section{WATER REACTOR CORROSION CHARACTERISTICS}

While in the reactor, fuel cladding is subject to corrosion environments on both the coolant-side and the fuel-side. In-reactor corrosion phenomena will be briefly reviewed as a prelude to consideration of corrosion effects during dry storage.

\section{Coolant-Side Corrosion}

Tenacious, low-solubility oxides form on the coolant side of Zircaloy cladding during reactor operation (Figure C.2). The oxide film thicknesses for BWR and PWR fuel cladding increase as a function of time in-reactor. Only about $3 \%$ of LWR cladding oxidizes during reactor operation, and the oxides are generally thicker and less uniform on BWR cladding than on PWR cladding at similar exposures. The $\mathrm{ZrO}_{2}$ films on BWR cladding are generally up to $50 \mathrm{~mm}$ thick at end of 1 ife. ${ }^{(C .11)^{2}}$ Nonuniform nodular $\mathrm{ZrO}_{2}$ oxides sometimes 
sometimes increase the total oxide thickness locally to $\sim 100 \mu \mathrm{m}$ on BWR cladding. PWR cladding oxide thicknesses up to $\sim 40 \mu \mathrm{m}$ are typical after three reactor cycles.

The oxides are stable under reactor and pool storage conditions. If exposed to oxidizing conditions (for example, air or oxygen) in dry storage, the Zircaloy cladding would further oxidize although the rate would be influenced by the reactor oxides. The effect of dry storage oxidation parameters is assessed in the body of this report.

Hydrogen absorption in Zircaloy cladding is another consequence of oxidation reactions involving water by the reaction:

$$
\mathrm{Zr}+2 \mathrm{H}_{2} \mathrm{O} \rightarrow \mathrm{ZrO}_{2}+2 \mathrm{H}_{2}
$$

A fraction of the hydrogen generated by the reaction enters the cladding. Hydrogen tends to embrittle Zircaloy, but hydrogen concentrations in LWR cladding seldom exceed 100 to 150 wppm. Under in-reactor tests, cladding with several hundred ppm has survived. Hydrogen levels in Zircaloy cladding are not regarded as high compared to levels that are known to cause serious embrittlement. Under reaction operation, Garzarroli et a 1. suggest $1000 \mathrm{ppm}$ as a limit. (C.7) Hydrogen tends to degrade the low-temperature impact properties of Zircaloy; however; fuel cladding appears to survive well in fuel handling and shipping operations. That experience includes several abnomal incidents, including dropping fuel assemblies during fuel movements in spent fuel pools. Zircaloy-clad fuel assemblies were dropped $\sim 8 \mathrm{~m}(25 \mathrm{ft})$ and impacted the bottom of the pool without causing apparent damage to the cladding and with no detectable radiation release. (C.3)

There was no evidence of fuel degradation on SS fuel cladding after $5 \mathrm{yr}$ in a borated pool or after storage in deionized water. (C.6) The oxide film that formed on SS cladding during PWR operation was too thin to be detectable by metallography. Stainless steel has a low solubility for hydrogen and does not form hydrides as Zircaloy does. 


\section{Fuel-Side Corrosion}

The following corrosion-related phenomena have been observed on the fuel side of Zircaloy cladding:

- oxide films on the cladding; the oxide fuel is the principal source of the oxygen

- hydride phases, sometimes manifested as "sunbursts" or areas of massive hydrides, initiate from the inner cladding surface and sometimes cause cracks through the Zircaloy cladding

- cracks apparently due to a combination of stresses at sites of pellet-cladding interaction (PCI) and aggressive fission product species.

SS-c lad LWR fuel does not show the oxidation, hydriding, or stress corrosion cracking ( $\mathrm{SCC}$ ) phenomena on inner cladding surf aces. $(\mathrm{C} .6)$

Exterior and interior cladding oxides have generally not appeared to cause performance-1imiting problems for LWR fuel. Hydriding from the outer surface has not been an operational problem although hydriding from the fuel side formerly caused numerous cladding failures that were essentially eliminated by lowering fuel moisture specifications. Solutions to the PCI problem are being investigated but are not yet fully resolved.

\section{CONDITION OF IRRADIATED FUEL PELLETS}

The $\mathrm{UO}_{2}$ fuel pellets swell under some conditions or densify under other conditions. Fuel fabrication parameters are now adjusted to control the degree of density change during irradiation. Cracks typically develop in fuel pellets during reactor operation. (C.6)

\section{CONDITION OF FUEL ASSEMBLY HARDWARE}

Table C.3 1 ists the types of hardware comprising water reactor fuel assemblies. There has been no evidence in postirradiation fuel handling or fuel assembly examinations that serious degradation of the fuel assembly components occurs in either reactor exposure or wet storage, with the exception 
of three cases (out of many thousand fuel handling situations) where an upper tie plate separated from a fuel assembly. $(C .13, C .14)$ Handling procedures were devised to retrieve the fuel assemblies.

\section{REFERENCES}

C.1. Acey, D. L., and J. C. Voglewede. July 1980. A Comparative Analysis of LWR Fuel Designs. NUREG-0559, U.S. Nuclear Regulatory Commission, Washington, D.C.

C.2. International Atomic Energy Agency. 1982. International Experience With Storage of Water Reactor Spent Fuel in Water Pools. IAEA/OECD Report, Vienna, Austria.

C.3. Johnson, A. B., Jr. September 1977. Behavior of Spent Nuc lear Fuel in Water Pool Storage. BNWL-2256, Pacific Northwest Laboratory, Richland, Washington.

C.4. Johnson, A. B., Jr., et al. May 1980. Annual Report - FY1979 Spent Fuel and Fuel Pool Component Integrity. PNL-3171, Pacific Northwest Laboratory, Richland, Washington.

C.5. Roberts, E., et al. May 1977. "Fuel Modeling and Performance of High Burnup Fuel Rods." In Proceedings of Topical Meeting on Water Reactor Fuel Performance, St. Charles, Illinois, pp. 133-135.

C.6. Johnson, A. B., Jr., et al. 1980. "Significance of Shippingport and Connecticut Yankee Fuel Examinations to Extended Water Storage of LWR Fue 1." DOE-SR-0009, Proceedings of IAEA Advisory Group/Specialists Meet ing, November 17-21, 1980, Las Vegas, Nevada.

C.7. Garzarolli, F., R. von Jan, and H. Stehle. 1979. "The Main Causes of Fuel Element Failure in Water-Cooled Power Reactors." Atomic Energy Review 17:31-128.

C.8. Page, R. D. March 1976. Canadian Power Reactor Fuel. AECL-5609, Atomic Energy of Canada Ltd., Toronto, Canada.

C.9. Bailey, W. J., et al. 1980-1981. Assessment of Current Onsite Inspection Techniques for Light-Water Reactor Fuel Systems. NUREG/CR-1380, PNL-3325, Vo T. 1 (July 1980) and Vol. 2 (January 1981), Pacific Northwest Laboratory, Richland, Washington.

C.10. Zima, G. E. November 1978. Comments on Crud as a Safety and Operational Factor of Independent Spent Fuel Storage Installations. NUREG/CR-0163, PNL-2657, Pacific Northwest Laboratory, Richland, Washington. 
C.11. U.S. Department of Energy. September 1981. Spent Fuel and Radioactive Waste Inventories as of December 31, 1980. DOE /NE-0017, Washington, D.C.

C.12. Johnson, E. R., Associates. November 1981. A Preliminary Assessment of Alternative Dry Storage Methods for the Storage of Commercial Spent Nuclear Fuel. DOE/ET/47929-1.

C.13. Pezzel10, J. A., and M. Lee. June 1973. "Fuel Performance of Indian Point Unit No. 1." ANS Trans. 16:102-103.

C.14. Northern States Power Company, Licensee Event Report 81-031/01X-1, Docket 50-282, Prairie Island-1 (May 1982). 


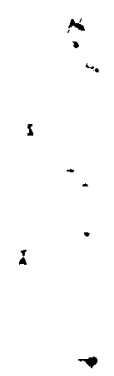


APPENDIX D

FISSION PRODUCTS -IN SPENT FUEL 


\section{FISSION PRODUCTS IN SPENT FUEL}

The fission product inventory within the spent fuel cladding changes with time after discharge from the reactor. For example, many of the iodine isotopes have relatively short half-lives as shown in Table D.1. Only ${ }^{127}$ I and ${ }^{129}$ I will be present when the fuel enters dry storage.

The decay for some of fission products that are considered to be potentially degrading to the resistance of the cladding to stress corrosion cracking (SCC) is displayed in Figure D.1. Table D.2 shows the concentrations of fission products remaining at reactor discharge and after $10 \mathrm{yr}$ of storage.

TABLE D.1. Cumulative Yields of the Most Abundant Iodine Isotopes for Thermal Fissioning of $235 \mathrm{~J}$

\begin{tabular}{|c|c|c|}
\hline Isotope & $\begin{array}{c}\text { Yield, atoms/ } 100 \\
\text { fissions } \\
\end{array}$ & Half-Life \\
\hline 127 I & 0.13 & Stable \\
\hline $129_{\text {I }}$ & 0.66 & Stable $e^{(b)}$ \\
\hline $131_{I}$ & 2.84 & 8.04 day \\
\hline 132 I & 4.21 & $2.29 \mathrm{~h}$ \\
\hline $133 m_{I}$ & 0.15 & $9 \mathrm{~s}$ \\
\hline 133 I & 6.77 & $20.8 h$ \\
\hline $134 m_{I}$ & 0.43 & $3.6 \mathrm{~min}$ \\
\hline $134 \mathrm{I}$ & 7.61 & $52.6 \mathrm{~min}$ \\
\hline $136 \mathrm{~m}_{\mathrm{I}}$ & $\begin{array}{l}6.41 \\
2.11\end{array}$ & $\begin{array}{l}6.59 \mathrm{~h} \\
46 \mathrm{~s}\end{array}$ \\
\hline${ }^{136} \mathrm{I}$ & 2.93 & $85 \mathrm{~s}$ \\
\hline & 3.25 & $24.6 \mathrm{~s}$ \\
\hline${ }^{138}$ I & 1.61 & $6.5 \mathrm{~s}$ \\
\hline${ }^{139} \mathrm{I}$ & 0.75 & $2.4 \mathrm{~s}$ \\
\hline & 0.23 & $0.86 \mathrm{~s}$ \\
\hline
\end{tabular}

(a) Data from Reference D.1.

(b) $30 \times 10^{6} \mathrm{yr}$. 


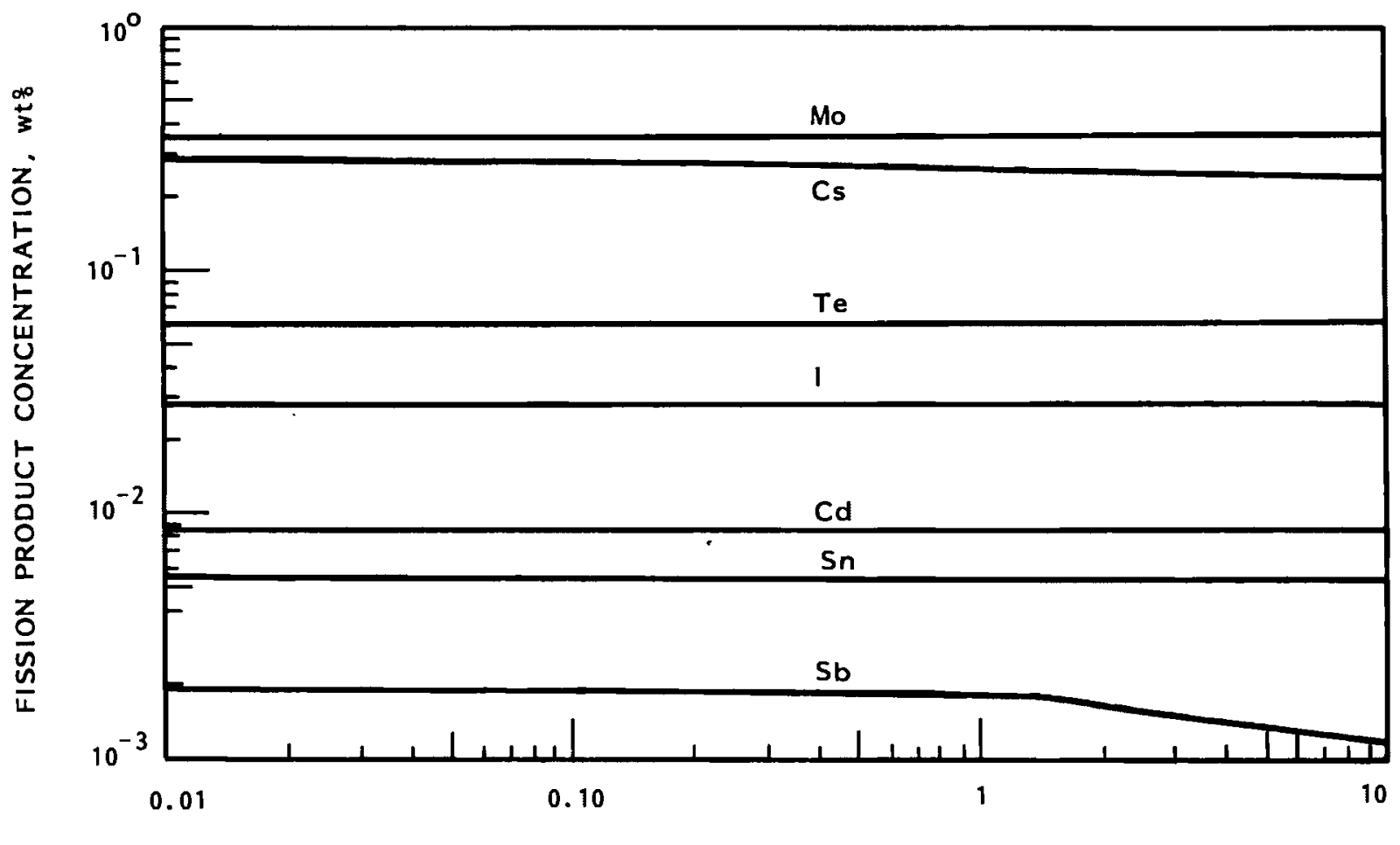

TIME AFTER DISCHARGE, yr

FIGURE D.1. Decay of Potentially Degrading Fission Products to $\mathrm{C}$ ladding Resistance to Stress Corrosion Cracking 
TABLE D.2. Concentrations of Fission Products from LWR Fuel at Discharge and 10 yr after Discharge $(a)$ 


\section{TABLE D.2. (contd)}

\begin{tabular}{|c|c|c|}
\hline \multirow[b]{2}{*}{ El ement } & \multicolumn{2}{|c|}{ Concentration, wt\% (a) } \\
\hline & At Discharge & After $10 \mathrm{yr}$ \\
\hline At & $1.08 \times 10-23$ & $3.63 \times 10^{-24}$ \\
\hline $\mathrm{Rn}$ & $1.08 \times 10^{-}$ & $2.20 \times 10-15$ \\
\hline $\mathrm{Fr}$ & $1.09 \times 10^{-19}$ & $1.09 \times 10^{-19}$ \\
\hline $\mathrm{Ru}$ & $9.63 \times 10^{-13}$ & $1.81 \times 10^{-11}$ \\
\hline Ac & $3.46 \times 10^{-13}$ & $2.85 \times 10^{-12}$ \\
\hline Th & $4.47 \times 10^{-8}$ & $2.61 \times 10^{-7}$ \\
\hline $\mathrm{Pa}$ & $1.33 \times 10^{-8}$ & $1.85 \times 10^{-8}$ \\
\hline U & $9.55 \times 10^{1}$ & $9.55 \times 10^{1}$ \\
\hline $\mathrm{Np}$ & $5.25 \times 10^{-2}$ & $4.53 \times 10^{-2}$ \\
\hline $\mathrm{Pu}$ & $7.42 \times 10^{-1}$ & $7.18 \times 10^{-1}$ \\
\hline Am & $1.21 \times 10^{-2}$ & $4.38 \times 10^{-2}$ \\
\hline $\mathrm{Cm}$ & $4.15 \times 10^{-3}$ & $2.27 \times 10^{-3}$ \\
\hline BK & $1.58 \times 10^{-10}$ & $5.01 \times 10^{-14}$ \\
\hline$C f$ & $7.19 \times 10^{-11}$ & $2.06 \times 10^{-10}$ \\
\hline & $1.30 \times 10^{-14}$ & 0 \\
\hline
\end{tabular}

Total grams from fission $=3.70 \times 10^{4} \mathrm{~g} / \mathrm{tU}$ products

Total grams from actinides

$=\frac{9.63 \times 10^{5} \mathrm{~g} / \mathrm{tU}}{1.00 \times 10^{6}} \frac{\mathrm{g} / \mathrm{tU}}{\mathrm{g}}$

(a) Reference D.1.

(b) $w t \%=$ (grams of fission products/total grams of fission products $+U) 100$.

\section{REFERENCES}

D.1. Croff A. G. 1980. A User's Manual for the ORIGEN2 Computer Code. ORNL/TM-7175, Oak Ridge National Laboratory, Oak Ridge, Tennessee. 


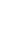

